\title{
Patrimônio rural no Espírito Santo: estudos para a sua preservação
}

Ana Aparecida Barbosa Pereira

Maria Angela C. S. Bortolucci (orientadora) 


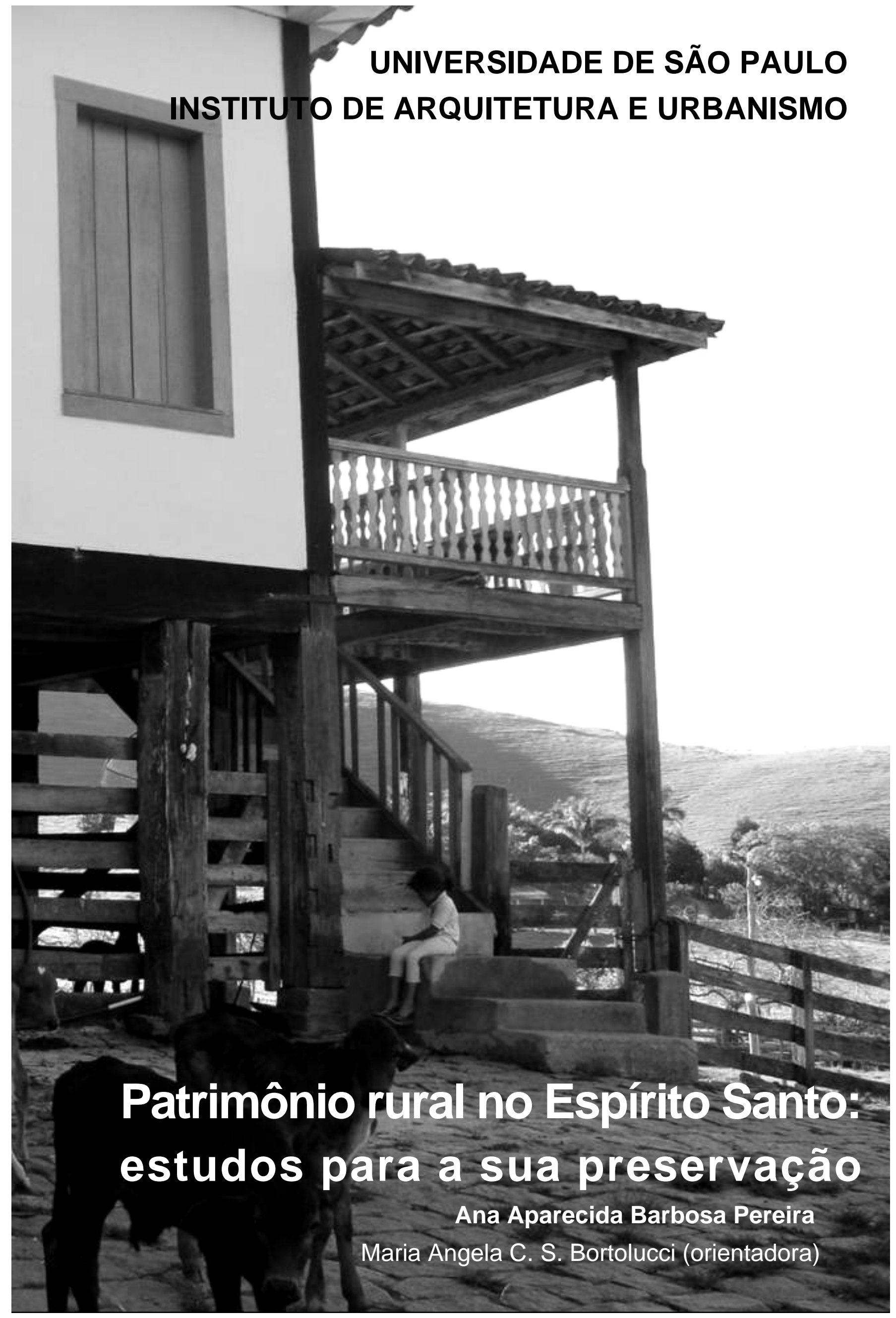




\section{ANA APARECIDA BARBOSA PEREIRA}

\section{Patrimônio rural no Espírito Santo: estudos para a sua preservação}

Tese apresentada ao Instituto de Arquitetura e Urbanismo da Universidade de São Paulo para obtenção do título de Doutora em Arquitetura e Urbanismo

Área de concentração: Teoria e História da Arquitetura e do Urbanismo

Orientadora: Prof. ${ }^{a}$ Dr. ${ }^{a}$ Maria Ângela P.C.S. Bortolucci 
AUTORIZO A REPRODUÇÃO TOTAL OU PARCIAL DESTE TRABALHO, POR QUALQUER MEIO CONVENCIONAL OU ELETRÔNICO, PARA FINS DE ESTUDO E PESQUISA, DESDE QUE CITADA A FONTE.

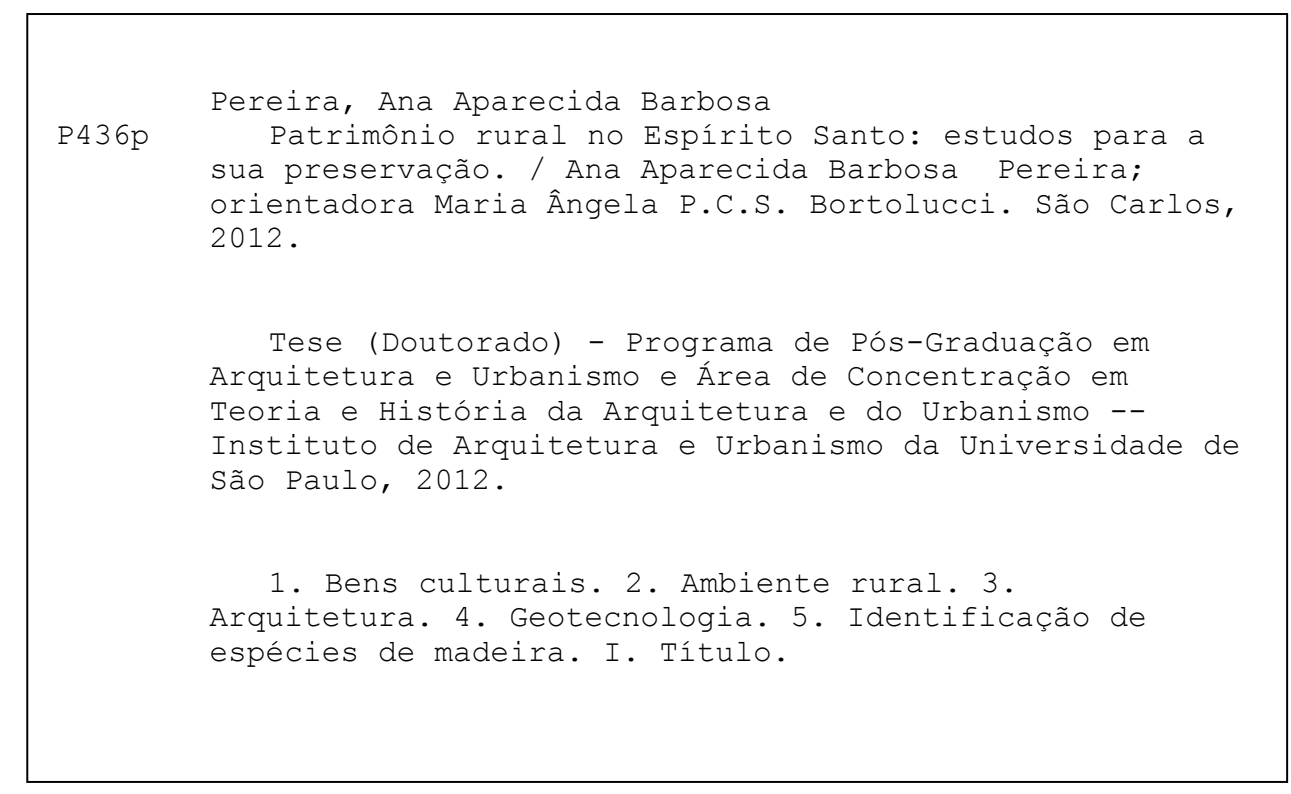


VERSÃO CORRIGIDA 


\section{FOLHA DE JULGAMENTO}

Candidato: Arquiteto e Urbanista ANA APARECIDA BARBOSA PEREIRA

Título da tese: "Ambiente rural e arquitetura rural no Espírito Santo: reflexões para a sua preservação".

Data da defesa: $24 / 07 / 2012$

\section{Comissão Julgadora:}

Resultado:

Profa. Dra, Maria Angela Pereira de Castro e Silva Bortolucci (Orientadora) APROUABA (Instituto de Arquitetura e Urbanismo/USP)

Profa. Associada Telma de Barros Correia APROUADA (Instituto de Arquitetura e Urbanismo/USP)

Prof. Dr. Marco Antonio Penido de Rezende APROVADA

(Universidade Federal de Minas Gerais)

Prof. Dr. Alexandre Rosa dos Santos

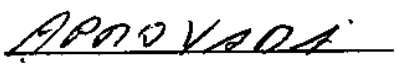

(Universidade Federal do Espírito Santo)

Prof. Dr. Francisco Sales Trajano Filho

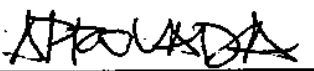

(Instituto de Arquitetura e Urbanismo/USP)

Presidente da Comissão de Pós-Graduação e Coordenador do Programa de PósGraduação em Arquitetura e Urbanismo: Prof. Titular Renato Luiz Sobral Anelli 
Wenceslau e Olandina

Olavo e Alexandre 
Agradeço à querida professora Maria Angela de Castro e Silva Bortolucci, por gentilmente me aceitar como orientanda conduzindo 0 trabalho com generosidade e tolerância perante os inúmeros desafios enfrentados, assim como ao professor Alexandre Rosa dos Santos, pelas preciosas orientações complementares certeiras na direção de um adequado recorte do objeto de estudo, sem o qual não estaríamos aqui neste momento. À professora Telma Barros e ao professor Vladimir Benincasa, pela importante contribuição durante a pesquisa e etapa de Qualificação da tese. A UFES e aos professores do Departamento de Ciências Florestais e da Madeira, em especial àqueles da área de Tecnologia de Produtos Florestais, José Tarcisio, Marina Donário, Graziela Vidaurre, Juarez Benigno, Clovis Hegedus, pelo auxílio para ampliação de minha dedicação à tese. Ao IPHAN, por estar sempre presente nas reflexões e ações inerentes à preservação do patrimônio cultural. Aos colegas da Escola de Arquitetura da UFMG pela confiança e contribuição. Ao Wagner Miranda e à Flavia Vitorino, por contribuírem em momentos de desafios, assim como à Rosely Tibúrcio. À querida Mariele Lukiantchuki e Rodrigo Jabur pela maravilhosa participação e auxílio nas diversas etapas desta pesquisa, sem os quais os desafios seriam maiores. À Ana Cecília Rocha Veiga pelas orientações e auxilio em demandas diversas. Aos funcionários da Biblioteca da EA UFMG, EESC USP, CCA UFES e da Biblioteca Municipal de Alegre. Ao Programa de Pós Graduação em Arquitetura e Urbanismo do IAU da USP, especialmente ao Geraldo, Marcelinho e Caio. Ao Estevão Giacomini, Fernando Coelho, Walter Boschetti, pela importante participação no desenvolvimento desta pesquisa. Aos proprietários da fazenda Fortaleza, em especial, Antônio Junior, por abrir as portas da sua casa para a pesquisa científica. À Cheyenne pela preciosa contribuição para definição da área de estudo. À dona Zélia, pela alegria dedicada à história de Alegre e região. À Gleissy, Mikaio e Mateus, pela paciência em compartilhar a família com o mundo da ciência. Ao IDAF, em especial ao Jésus Fernando, pela ampla disponibilidade em atender as demandas da pesquisa. Ao Aldieres, pelo apoio inicial aos estudos temáticos capixabas. Ao Sr. Elizeu, por nos guiar carinhosamente a fazendas da região. Aos meus condutores familiares, que representam minha vida, pelo apoio e compreensão para o encerramento desta etapa. 
Para obter algo que você nunca teve, precisa fazer algo que nunca fez.

Chico Xavier 


\section{Resumo}

PEREIRA, Ana A. B. Patrimônio Rural no Espírito Santo: estudos para a sua preservação. 2012. 92f. Tese (doutorado) - Instituto de Arquitetura e Urbanismo. Universidade de São Paulo, São Paulo, 2012.

Esse trabalho identifica como relevante o acervo de bens culturais rurais localizados no sul do estado do Espírito Santo, e adota a região localizada entre os rios Itapemirim e Itabapoana para investigação. A fazenda Fortaleza, Alegre, ES, de meados do século XIX, foi eleita como exemplar piloto para elaboração de reflexões pautadas na utilização de ferramentas da geotecnologia, para acervo de bens culturais do ambiente rural. Para isso, foi realizada análise fenomenológica da fazenda entendida como única em sua unidade potencial, a partir da qual se considera pertinente a incorporação de análises morfométricas do meio ambiente rural e utilização do Analytic Hierarchy Process - AHP, para obtenção da Sensibilidade Cultural para o Ambiente Rural - SCAR. Definiu-se como área elegível da fazenda Fortaleza, aquela obtida através da delimitação por $500 \mathrm{~m}$ em linha reta, com origem em cada um dos quatro extremos do telhado da Casa Sede, por apresentar escala adequada aos estudos. Com o auxílio de manuais de agricultura do século XIX, percepção da fazenda em sua essência enquanto bem cultural e mapeamento do uso da terra, foram relacionados os Fatores de Fragilidade Morfológica e Cultural - FFMC para obtenção da SCAR. Adotou-se o FFMC de maior peso estatístico, Casa Sede, conforme AHP, para detalhamento histórico e científico. Em seguida, a partir de análise macroscópica, foram identificadas as principais espécies de madeiras utilizadas no sistema construtivo da Casa Sede da fazenda Fortaleza. Por fim, o trabalho traz como principal contribuição, a disponibilização de procedimento adequado à identificação e gestão do patrimônio rural do Espírito Santo.

Palavras chaves: Bens culturais, Ambiente rural, Arquitetura, Geotecnologia, Identificação de espécies de madeira 


\begin{abstract}
PEREIRA, Ana A. B. Rural Heritage in the Espírito Santo, Brazil: studies for its preservation. 2012. 92f. Tese (doutorado) - Instituto de Arquitetura e Urbanismo. Universidade de São Paulo, São Paulo, 2012.

This work chose as relevant cultural collection the property located in rural southern state of Espirito Santo, and adopts the region located between the rivers Itapemirim and Itabapoana for investigation. We used the Fortaleza farm how study model. It was built in first half of nineteenth century in the municipality of Alegre/ES. Thus we performed the phenomenological analysis on the farm which seen as unique in its potential unity from which we consider appropriate the incorporation of morphometric analysis of the environment rural using the Analytic Hierarchy Process - AHP to obtain the Cultural Sensitivity for the Rural Environment - CSRE. Thus, we used in the study an area of 500m around of house, starting from the four ends of main roof. With the aid of agricultural manuals of the nineteenth century and the perception of the farm as precepts of phenomenology and mapping of use the land we related factors of Morphological and Cultural Fragility- MCF, to obtain the CSRE. The biggest MCF used was "main house" according of AHP for historical and scientific detail. Therefore, we identify from macroscopic analysis which were the main species of wood used to building of main house of the farm Fortaleza. This work brings as the main contribution the appropriate procedure to identify and manage the rural heritage of Espirito Santo.
\end{abstract}

Key words: Rural environment, Architecture, Geotechnology,Identification of wood specie, Cultural goods. 


\section{Sumário}

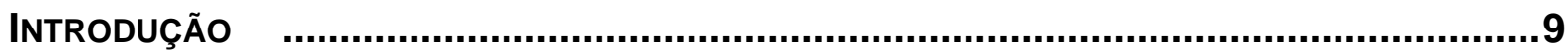

1. O SUL DO ESPÍRITO SANTO .........................................................................16

1.1. Apropriação do território ...............................................17

1.2. Arquitetura entre os vales do Itabapoana e Itapemirim ................45

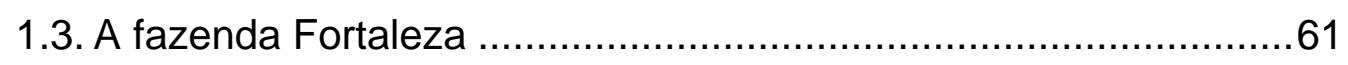

2. PATRIMÔNIO RURAL: PROCEDIMENTOS PARA A SUA PRESERVAÇÃO ..........................65

2.1. Manuais de agricultura do século XIX: ocupação do espaço e utilização da madeira .........................................................66

2.2. A fenomenologia como leitura do patrimônio............................71

2.3. Geotecnologia e preservação cultural .................................78

2.3.1. Morfometria para o patrimônio rural ................................80

2.3.2. Evolução do uso da terra para os anos de 1970 e 2009 .......90

2.3.3. Sensibilidade Cultural para o ambiente rural: um conceito....96

3. FAZENDA FORTALEZA: UMA ANÁLISE........................................................... 123

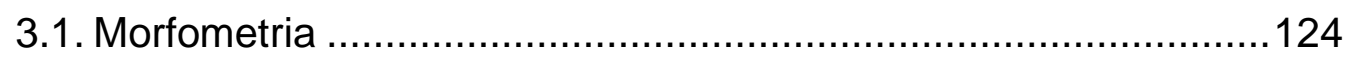

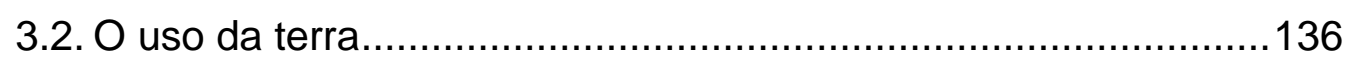

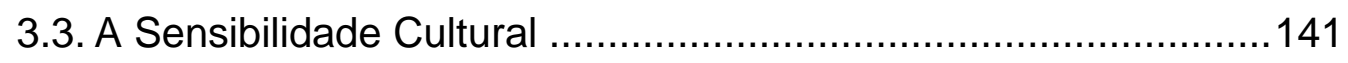

3.4. Fragilidade Morfológica e Cultural da arquitetura rural: a madeira na fazenda Fortaleza ............................................................. 149

CONCLUSÃO $\quad$............................................................................................172

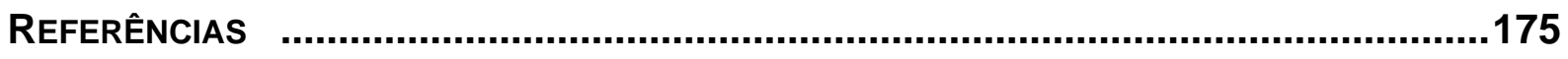

ANeXo A - Exemplo Metodológico de uma Aplicação do Método AHP Proposto

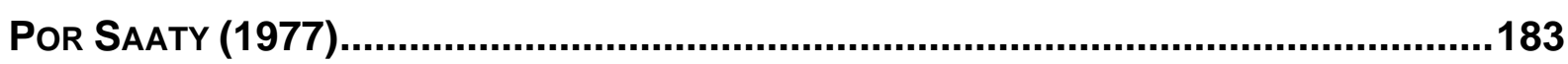





\section{INTRODUÇÃO}

Os estudos abordados nesta pesquisa são resultados de inquietações inerentes à trajetória profissional da autora, considerando pesquisas embrionárias referentes ao patrimônio cultural ao longo da graduação em Arquitetura e Urbanismo, que foram ampliadas ao se tornar funcionária do Instituto do Patrimônio Histórico e Artístico Nacional - IPHAN, quando aflorou intenso e profundo envolvimento junto às demandas de salvaguarda do patrimônio nacional brasileiro. A partir de então, buscou-se por meio do mestrado em Arquitetura e Urbanismo ampliar o conhecimento científico referente ao tema da conservação de bens culturais, discutindo o desafio da restauração urbana. Com tradição profissional no universo mineiro, cujo acervo é amplamente estudado, e ao passar à condição de professora da Universidade Federal do Espírito Santo, não era possível deixar de observar o precioso acervo do patrimônio rural do estado do Espírito Santo, que é pouco estudado e preservado, apesar de ações recentes para mudar este quadro. Entendendo que o reconhecimento de um bem cultural e o respeito por sua condição existencial são fatores determinantes para as ações de preservação e, com o efetivo comprometimento com o patrimônio nacional, tornou-se necessário aceitar o desafio de contribuir com as demandas de salvaguarda do acervo do patrimônio rural do Espírito Santo.

Nesse contexto, destaca-se a importância geográfica e histórica da região sul do Espírito Santo, com um patrimônio rural de relevância, que surgiu em um momento de mudanças políticas brasileiras, tanto no que se refere à abdicação de Dom Pedro I, quanto aos conflitos políticos em Minas Gerais, que influenciaram a ocupação do interior do Espírito Santo, assim como a consolidação desta ocupação com a crise do sistema escravista. Essa condição traz à região a necessidade do devido reconhecimento de seus valores culturais, visando a sua permanência para gerações futuras. Uma vez que o acervo do patrimônio rural do café do sul do estado não está, nem mesmo, inventariado, ocorre, portanto, a indicação de urgência para o desenvolvimento de procedimentos e ações adequadas a sua 
compreensão e reconhecimento. Destaca-se que neste contexto, o IPHAN criou em 2011 um grupo de trabalho na região Sudeste do Brasil, visando ao estudo do patrimônio rural do café nos estados que a compõe, o que reforça essa carência e necessária ação em prol da preservação dos bens culturais desse período histórico.

Ao entender as importantes condições historiográficas e físicas do patrimônio rural sul capixaba, elucida-se a condição de sua permanência na região enquanto bem cultural de interesse de preservação. Percebe-se então, que o desenvolvimento de um sistema de identificação e análise das fazendas, a partir de uma tecnologia que possibilite o estudo da superfície terrestre adaptada às informações e necessidades deste espaço construído no ambiente rural, é relevante. Assim, para a manutenção deste importante acervo cultural, a utilização de informações cadastrais cientificamente adequadas é primordial. Há que se considerar ainda, ferramentas para análises de dados espaciais, que permitam conhecer a ocupação e transformação do meio físico. Assim, objetiva-se a utilização de metodologia inédita para o universo cultural rural, que contemple análises morfométricas e que destaque a delicadeza do acervo para com as demandas culturais.

Dessa forma, esta pesquisa pretende utilizar geotecnologias como instrumento de preservação e gestão do patrimônio rural do café no sul do Espírito Santo, além dos métodos tradicionais de pesquisa, por acreditar ser um instrumento atual, eficiente e de baixo custo para tomada de decisões perante os desafios da conservação do patrimônio rural. Os métodos de cadastro e estudo do patrimônio rural adotados no Brasil, em sua maioria, são ainda tradicionais e insuficientes para as necessidades de preservação atuais. Entretanto, estão em curso trabalhos e iniciativas inovadoras que necessitam ser ampliadas com tecnologias modernas, visando aumentar a eficiência e precisão de tais ações, e que contemplem, ainda, maiores investimentos para o aprimoramento destas tecnologias aplicadas aos bens culturais rurais, no sentido de se obter o adequado controle dos dados cadastrais na direção de melhorias futuras à correta manutenção do acervo.

Faz parte ainda do propósito desta pesquisa disponibilizar princípios que reúnam de maneira lógica, elementos da geotecnologia para identificação e análise do patrimônio rural no Espírito Santo, de modo que seja possível aperfeiçoar o trabalho de registro e conservação desse acervo. Evidenciar que a utilização de tais 
técnicas auxilia na compreensão do patrimônio rural, na área montanhosa do sul do Espírito Santo, como parte do território percebido em sua totalidade, e objeto único na conformação do ambiente rural por meio de estudos de sua morfologia e da sensibilidade cultural nesse espaço. Destaca-se para as análises, de acordo com o acervo de bens culturais rurais do sul do estado, apenas uma fazenda, a Fazenda Fortaleza, localizada na região compreendida entre os vales do rio Itapemirim e rio Itabapoana.

Para o processamento de imagens, análise espacial, modelagem numérica de terreno e consulta a bancos de dados espaciais foi utilizado o ArGis 10.0 como instrumento do Sistema de Informação Geográfica. No desenvolvimento de procedimentos para estudo do patrimônio rural a partir de geotecnologias, as contribuições de Britaldo Silveira Soares Filho, Alexandre Rosa dos Santos e Ana Clara Mourão Moura foram primordiais. Por conseguinte, para a obtenção da Sensibilidade Cultural para o ambiente rural pautou-se em Saaty (1977), na busca pelo mapeamento da condição de sensibilidade cultural da fazenda Fortaleza.

Igualmente importante no contexto específico desta pesquisa, que utiliza geotecnologias como ferramentas de auxilio à preservação do patrimônio rural do sul do Espírito Santo, é o entendimento da dinâmica do ambiente rural de sua origem e constituição na região a partir de meados do século XIX. Para esse conhecimento histórico, que aliado à realidade atual constitui demandas de preservação, a pesquisa considerou, nas análises da fazenda Fortaleza, a fundamental contribuição dos "tratados" sobre culturas em fazendas como as obras: Memória sobre a fundação de uma fazenda na Província do Rio de Janeiro, Barão de Paty (WERNECK, 1878), textos apresentados por Frei Veloso em o Fazendeiro do Brasil, com destaque para o Fazendeiro de Café na llha de São Domingos, de Laborie (1799).

Aceitando os desafios de compreender o objeto cultural em estudo em sua essência, a fazenda Fortaleza, e percebendo como ele se manifesta, visando às análises geotécnicas, foram adotados os parâmetros da fenomenologia, pautados nas discussões apresentadas por Reale (2006), Beatriz Khul, Cesare Brandi (2005) e fundamentalmente por Flávio Carsalade (2007) em suas abordagens quanto ao 
significado das obras especiais feitas pelo homem, a ampliação do conceito de obra de arte para bem cultural e sua condição de preservação.

Assim como Moura (2011) utiliza SIG para estudos da preservação dos elementos ígneos da fachada da casa denominada Chácara do Barão, Serro, MG, considera-se pertinente nos estudos aqui desenvolvidos para a Fazenda Fortaleza a identificação das principais espécies de madeira utilizadas em sua estrutura, onde foram destacadas as contribuições de Mainieri at Chimelo (1989), através das fichas de características das madeiras brasileiras.

Para se eleger a Fazenda Fortaleza como principal objeto de estudo realizouse pesquisa histórica arquitetônica, incluindo levantamento fotográfico e métrico simplificado identificação de características básicas do sistema construtivo e de remanescentes arquitetônicos de fazendas entre os vales do rio Itapemirim e rio Itabapoana. A fazenda Fortaleza do período do café, localizada no município de Alegre, sul do Espírito Santo, foi estudada por instrumentos geotecnificados, que compreendem análise morfométrica, ambiental e hidrológica. Identificou-se um ponto em GPS das coordenadas geográficas da fazenda Fortaleza, localizando-a no Planeta Terra, a partir de imagem de satélite de 2009. Em seguida, criou-se uma linha de 500 (quinhentos) metros em relação aos extremos do telhado da Casa Sede da fazenda, como definidora da área de pesquisa do ambiente rural, por considerar que essa distância possibilita leituras de escala métrica satisfatórias às análises necessárias às reflexões desta tese. Entre os vales dos rios Itapemirim e Itabapoana, o estudo relacionou uma amostra de fazendas por região de ocupação, ressaltando que no final do século XIX e início do século XX, na área relacionada, havia poucos municípios e alguns povoados.

A pesquisa bibliográfica e os levantamentos de dados sobre o tema do Patrimônio Cultural Rural do sul do Espírito Santo foram realizados a partir de consultas on-line e físicas em bibliotecas e arquivos sobre a história de ocupação da região e seus principais condicionantes. Além disso, foi identificado o período histórico em que a região foi ocupada, o momento de seu apogeu econômico no século XIX, tendo os caminhos, rios e o cultivo do café como eixo principal de delimitação da área de estudo. As principais fontes de pesquisa foram: Arquivo Público do Estado do Espírito Santo (APES), Instituto Histórico e Geográfico de 
Alegre (IHGA), Biblioteca da Universidade Federal do Espírito Santo (UFES), Sindicato Rural, Instituto de Defesa Agropecuária e Florestal do Espírito Santo (IDAF), Biblioteca Municipal de Alegre e acervos pessoais de pesquisadores locais. Além disso, utilizou-se ainda outras fontes diversas, bibliotecas e arquivos virtuais.

$\mathrm{Na}$ produção historiográfica regional sobre o tema, foram consultados Processos de Terras, e principalmente, os Relatórios dos Presidentes da Província, apresentados à Assembleia Legislativa Provincial. Além disso, foram pesquisados Anais da Assembleia, correspondências de autoridades das províncias ao Governo Central, registros da imprensa e obras da época. Tais fontes possibilitaram caracterizar as condições gerais do Espírito Santo ao longo do século XIX, com destaque para as fontes bibliográficas referentes aos relatórios dos governadores da província no século XIX, principalmente Francisco Alberto Rubim e Ignácio Accioly de Vasconcellos. Os relatórios dos governadores foram explorados com fácil acesso pelo Arquivo Público do Estado do Espírito Santo, disponível on-line pelo site do arquivo, aqueles do período entre 1842 a 1888, e também disponíveis pela Biblioteca de Chicago, abrangendo o período de 1833 até 1930. Nesse universo, cabe destacar que o Arquivo Público do Espírito Santo mantém disponível um banco de dados organizado por ordem cronológica das ementas abordadas em leis, decretos e resoluções, do período de 1835 a 1888, dentro de Legislação Provincial do Espírito: Ementário 1835-1888.

O conhecimento das especificidades da área de pesquisa contou com os estudos de Bravo (1998), Marins (1920), Almada (1984) e Almada (1993), que conferiram importantes esclarecimentos sobre a história de ocupação e cultivo de café no vale do rio Itapemirim. O trabalho de Almada (1993) possibilitou acesso sistematizado sobre a propriedade rural e o latifúndio na região do Itapemirim. Saleto (1996) trouxe destacada contribuição para as informações das questões econômicas e sociais na formação do Espírito Santo, assim como os clássicos, Saint-Hilaire (1974) e Oliveira (1975), que abordam temas tradicionais sobre a história do Espírito Santo.

A presente tese está estruturada em três capítulos. O primeiro elucida sobre o Espírito Santo Rural, observado a partir dos caminhos que conduziram principalmente os mineiros ao estado capixaba, atravessando a região entre os 
vales do rio Itapemirim e rio Itabapoana. Em seguida, busca-se contextualizar a formação do território do sul do estado, pautada no pioneirismo da produção cafeeira da região, juntamente com a contribuição do imigrante europeu da segunda metade do século XIX, com a pequena propriedade em contraponto ao predomínio do tradicional latifúndio na região, Posteriormente, identifica-se a arquitetura rural na região, destacando os principais exemplares, relacionados a partir de amostragem e execução de levantamento físico arquitetônico básico. Neste capítulo ainda, é apresentada a fazenda Fortaleza como exemplar adequado aos estudos desenvolvidos pela pesquisa.

O segundo capítulo consta da apresentação dos conceitos que fundamentaram as reflexões e os estudos da tese, tendo como destaque os manuais de agricultura do século XIX, por se tratar de um importante instrumento de auxílio às análises da morfometria de uma bem cultural rural. Contempla o mapeamento do uso da terra de uma fazenda durante 1970 e 2009, como instrumento de análise da evolução do uso da terra em regiões de patrimônio rural. Para isso, utiliza de ferramentas da geotecnologia, auxiliada pelos princípios da fenomenologia para compreensão do ambiente rural como bem cultural. A implementação de tais procedimentos de estudo pautou-se na fazenda Fortaleza, localizada em Alegre, e eleita para estudo dentre as fazendas relacionadas na região dos vales dos rios Itabapoana e Itapemirim. Este capítulo objetiva evidenciar a metodologia de estudo adotada para a obtenção dos resultados, através da utilização de manuais de agricultura para identificação do objeto e leitura fenomenológica do bem cultural para então, a partir de ferramentas geotecnificadas, se obter instrumentos de registro e gestão de dados em prol da preservação do patrimônio rural.

O terceiro e último capítulo utiliza os dados do uso da terra para, a partir do método AHP, desenvolvido por Saaty (1977), obter a sensibilidade cultural do ambiente rural, vista como importante instrumento de gestão do patrimônio rural. A partir dos parâmetros de mapeamento do uso da terra, relacionou aqueles considerados fatores de fragilidade morfológica e cultural, tendo a Casa Sede da fazenda Fortaleza, como elemento de maior peso estatístico, por isso, eleita para estudos aprofundados, destancando-se em seu sistema construtivo a identificação de espécies de madeira estruturais. Nessa tarefa, contou com a colaboração do Laboratório de Tecnologia da Madeira do Centro de Ciências Agrárias da 
Universidade Federal do Espírito Santo - CCA UFES, onde foi possível identificar pelo método macroscópico, a partir de parâmetros definidos por Mainieri at Chimelo (1989), quais as madeira utilizadas na construção da fazenda. Destacam-se aqui os resultados e análise destes dados na aplicabilidade da metodologia proposta pela pesquisa.

Considera-se fundamental tais discussões, uma vez que a carência quanto às ações de preservação do acervo rural no sul do Espírito Santo é evidente. Atualmente, programas de incentivo à criação de novas metodologias para inventário e gestão do patrimônio rural na região sudeste estão em curso, tanto em caráter estadual como regional. Assim, esta pesquisa pretende responder em parte, as indagações e demandas desta natureza na busca efetiva de se colaborar com a preservação do patrimônio nacional, neste caso, referenciado pelo universo rural do sul do estado do Espírito Santo. 
1. O SUL DO ESPÍRITO SANTO 
As particularidades que levaram à ocupação tardia do interior do Espírito Santo até atingir a configuração territorial atual, ficando séculos em estreita faixa litorânea, assim como a sua condição fundiária, são importantes referências para o conhecimento da formação do universo rural ao longo do século XIX no estado.

\subsection{Apropriação do território}

Ocupação e formação da região

Atualmente, há no centro-sul do Espírito Santo o predomínio do cultivo de café. Como a região é montanhosa, grande parte da área agriculturada ocorre em topografia com elevada declividade, configurando peculiaridades quanto à técnica de cultivo. O Espírito Santo é o segundo maior produtor de café do Brasil, com predomínio do Conilon, mas produz ainda o café do tipo Arábica para exportação. A tradição cafeeira no estado se fez a partir de meados do século XIX, principalmente quando o interior da região sul foi ocupado. Próximo a Vitória, região central e São Mateus, no norte, também cultivaram café no século XIX, mas a produção do sul do estado foi mais expressiva e em maior volume, muito em função da proximidade com o Rio de Janeiro (ALMADA, 1984).

É marcante na paisagem a cultura do café no sul do estado, com produção consolidada e expressiva e condições topográficas adversas, o que propicia sabor peculiar ao café e leva à busca pela importância do reconhecimento dessa tradição no estado. O café surgiu no sul do Espírito Santo em um momento de necessidade do avanço das fronteiras da cultura do norte fluminense, e ainda em condições de crise do sistema escravista e início da política de imigração de europeus para o Brasil no século XIX. Essa realidade propiciou basicamente duas vertentes para a 
forma de ocupação e cultivo do café na região. A área central do estado apresenta predomínio de pequenas propriedades oriundas da ocupação direta por imigrantes ou fragmentação de grandes fazendas açucareiras, após a chegada dos mesmos. Já na região entre os vales dos rios Itapemirim e Itabapoana predominam áreas agriculturadas com origem no latifúndio, conforme política do norte fluminense, e trajetória brasileira da propriedade da terra. De todo modo, Saint Hilaire (1974) relata que a ocupação do Espírito Santo permaneceu apenas no litoral desde o descobrimento do Brasil até o início do século XIX, em uma faixa de quatro léguas ${ }^{1}$. A produção agrícola era destacada pelo cultivo principalmente de mandioca no norte do estado, com forte influência e disputa territorial com a Bahia, e cana de açúcar na região central e sul do estado na faixa litorânea.

O Espírito Santo mantinha uma estrutura social e administrativa pobre e limitada diante de algumas áreas do desenvolvimento do Brasil até aquele momento. Essa condição de ocupação concentrada no litoral é entendida como consequência de restrições colocadas pela administração portuguesa, visando à maior segurança para as Minas Gerais, que proibiu o avanço da ocupação do Espírito Santo para o Sertão. Tal isolamento foi reforçado ainda pelas montanhas da Serra do Caparaó e rio Doce que representam barreiras geográficas. Além destas limitações naturais e administrativas, a presença de índios, avessos à ocupação de suas terras por outros povos, contribuiu para a restrição da expansão do estado do Espírito Santo para o interior. De maneira geral, tais condicionantes levaram ao atraso da ocupação da região no sentido litoral interior. Simultaneamente, Minas Gerais avançava e expandia sua influência com significativo movimento migratório. No final do século XVIII e início do século XIX, este fluxo foi intenso tendo em vista o relativo esgotamento das minas de ouro, principalmente nas regiões de Ouro Preto e São João Del Rei (GONÇALVES, 2008). Esse deslocamento de mineiros foi decisivo para a ocupação do interior do Espírito Santo, assim como foi a expansão das lavouras de café do norte do Rio de Janeiro para a ocupação de parte sul do estado.

A consolidação da ocupação da área entre os vales dos rios Itapemirim e Itabapoana, no sul do Espírito Santo, foi ainda marcada pela chegada de mineiros vinculados aos conflitos políticos na região de Ouro Preto e São João Del Rei, por volta de 1833. Autoridades administrativas e fazendeiros fugiram de Minas Gerais

\footnotetext{
${ }^{1}$ Medida itinerária equivalente a 6 Km (OLIVEIRA, 2009)
} 
por cometeram crimes políticos. O guarda mor Manoel Esteves de Lima, importante desbravador do Vale do Itapemirim, ao retornar a Mariana (MG), foi preso por dois anos entre 1833 e 1835 (GONÇALVES, 2008). Essa ação de expansão da mobilidade dos mineiros pelo território ocasionou uma presença expressiva destas pessoas em regiões de divisa com disputa de áreas e busca de definição dos limites entre as províncias. No início do século XIX, Minas Gerais se fazia presente em grande parte das terras que chegavam até Cachoeiro do Itapemirim, destacando os municípios de Dores do Rio Preto, luna, Guaçuí, junto ao rio Itapemirim. A estrada, hoje Rodovia 482, no trecho capixaba, foi aberta por João do Monte da Fonseca no início do século XIX e mantida por muitos anos pelo Guarda Mor Manoel Esteves de Lima, ambos oriundos da região de Mariana (MG), conforme esclarece Gonçalves, (2008). Por outro lado, já mais ao sul, sob forte raio de ação do Rio de Janeiro, junto ao vale do rio Itabapoana, a ocupação da região foi fortemente marcada pela presença de fluminenses e ainda por mineiros oriundos da região dos Campos das Vertentes.

O café fez a fortuna do centro sul do Brasil, irradiando-se, a partir de Resende, para jusante do rio Paraíba [...], onde alcançou, já no final do século, Cantagalo, Cordeiro, Itaperuna e Porciúncula, esbarrando na zona da cana de açúcar em Campos, sem nela penetrar. Mudando de direção, implantou-se em Minas (Leopoldina, Muriaé, Carangola, Manhuaçu) e no Espírito Santo (Cachoeiro do Itapemirim) (BOLTSHAUSER, 1972).

Esses percursos que levaram à ocupação do território no Espírito Santo foram direcionados majoritariamente sob a condução dos rios e bacias hidrográficas. Neste sentido, percebe-se que os afluentes do Rio Paraíba do Sul, que estão em território Mineiro, conduziram mineiros ao Rio de Janeiro, que saíram das cidades e áreas de decadência econômica e conflitos políticos, se aventurando por áreas de mata densa no Rio de Janeiro, Zona da Mata mineira e sul do Espírito Santo. Outros mineiros vieram por meio de rios da bacia hidrográfica do rio Doce, a qual inclui o Ribeirão do Carmo que nasce em Ouro Preto (MG) e passa em Mariana (MG). Esses mineiros também se deslocaram para a Bacia do Itabapoana e Itapemirim já no Espírito Santo.

A configuração das bacias hidrográficas e suas relações com a ocupação da região sul do Espírito Santo são determinantes para o surgimento dos caminhos que 
definiram a ocupação da área entre os vales do rio Itapemirim e rio Itabapoana. Esses dois rios deságuam direto no Oceano Atlântico e representam bacias hidrográficas próprias e importantes, além de estarem cercados pelas bacias hidrográficas do rio Paraíba do Sul e Rio Doce. A bacia hidrográfica do rio Itabapoana faz divisa com a bacia hidrográfica do rio Doce e rio Paraíba do Sul, importante área produtora de café no Rio de Janeiro ao longo do século XIX, e conecta-se à região do Campo das Vertentes (MG). Já a bacia hidrográfica do rio Itapemirim faz divisa com a bacia do rio Benevente e rio Novo, no Espírito Santo, e bacia hidrográfica do rio Doce, representando destacado caminho de movimentação de mercadorias para Minas Gerais. No Espírito Santo, o Porto de São Mateus, Vitória e Itapemirim representavam a conexão de Minas com outras regiões e países por via marítima. Caminhos eram abertos até os trechos dos rios que então se tornavam navegáveis quando passavam a levar e trazer produtos para o Sertão.

Durante muito tempo o governo havia proibido toda a comunicação entre as capitanias de Minas Gerais e Espírito Santo, querendo assim tornar mais difícil o contrabando do ouro. Depois da chegada do Rei D. João VI ao Brasil, o Governo tomou a resolução de fazer um caminho que fosse da Vila da Vitória à Vila de Mariana. O caminho teve inicio do lado da província do Espírito Santo, na aldeia de Santa Maria (RUBIM, 1844). Nesse amplo circuito de caminhos e movimento migratório, cabe ainda destacar que durante o período colonial as terras do Brasil pertenciam à Ordem de Cristo e esta, por concessão pontifícia, possuía o direito da criação de igrejas².

Até 1822, antes da Independência do Brasil, os soberanos de Portugal propunham ao papa a criação de dioceses e apresentavam bispos e párocos (BOTELHO, 1987). A então capitania do Espírito Santo, desde sua origem, teve seu território espiritual subordinado ao bispado da Bahia e a partir de 1575, passou à Prelazia de São Sebastião do Rio de Janeiro. Desmembrada do bispado da Bahia, o território desta nova Prelazia estendia-se desde a capitania de Porto Seguro até o Rio da Prata, que em 1676, passou a Diocese do Rio de Janeiro, que em 1892 se tornou Arcebispado. Em 1748, Mariana, MG, dentro do contexto brasileiro, passou à sexta diocese, depois do bispado da Bahia (1555), Rio de Janeiro (1676), Olinda (1676), Maranhão (1677) e Pará (1719). Antes, a província das Minas Gerais dava

\footnotetext{
${ }^{2}$ Para maiores entendimentos da relação entre igreja e poder, ver Garcia (2008).
} 
obediência espiritual aos Bispos do Rio de Janeiro. Nesse contexto, parte do território capixaba ficou sobre a jurisdição religiosa mineira, já que até 1838, Guaçuí, ES, pertencia ao município de Viçosa, MG (ABREU, 1960).

As terras brasileiras pertenciam a Igreja e eram administradas pela Coroa Portuguesa, todavia, percebe-se que a influência da Igreja ia muito além das questões religiosas em si. Nesse contexto, compreender as influências das dioceses da Bahia, Rio de Janeiro e Minas Gerais relacionadas às terras do Espírito Santo auxilia o entendimento das disputas territoriais e conclusão da definição de divisas ocorrida apenas no século XX. De acordo com Abreu (1960), ao contrário das capitanias de Ilhéus e Porto Seguro, a do Espírito Santo permaneceu "talvez pela dificuldade de contentar na partilha, Bahia, Minas Gerais e Rio de Janeiro; mas a simples inspeção do mapa mostra que este é um estado anômalo que não há de continuar como aparece". A Figura 1 ilustra esta condição de domínio e disputas territoriais nas divisas do Espírito Santo, tendo no século XVIII e ainda início do XIX, ficado para o estado capixaba apenas a área compreendida entre o rio Doce e o rio Itapemirim. Ao norte, parte das terras pertencia a Minas e Bahia, ao leste e sudoeste, a Minas e ao sul, ao Rio de Janeiro, que definitivamente incorporou a antiga capitania de Paraíba do Sul, que chegou a pertencer ao Espírito Santo.

A condição de ocupação do Espírito Santo é peculiar, pois apesar da significativa faixa litorânea, o seu interior foi ocupado principalmente a partir de Minas Gerais, no início do século XIX. Em 1818, o território cultivado da capitania não avançava além de uma estreita faixa de quatro léguas de largura em relação ao litoral, e, além disso, conforme Saint-Hilaire (1978), "acham imensas florestas que se confundem com as de Minas Gerais e servem de asilo às tribos errantes dos botocudos, sempre em guerra com os portugueses". 


\section{EVOLUCÃO DOS LIMITES DO ESPÍRITO SANTO}

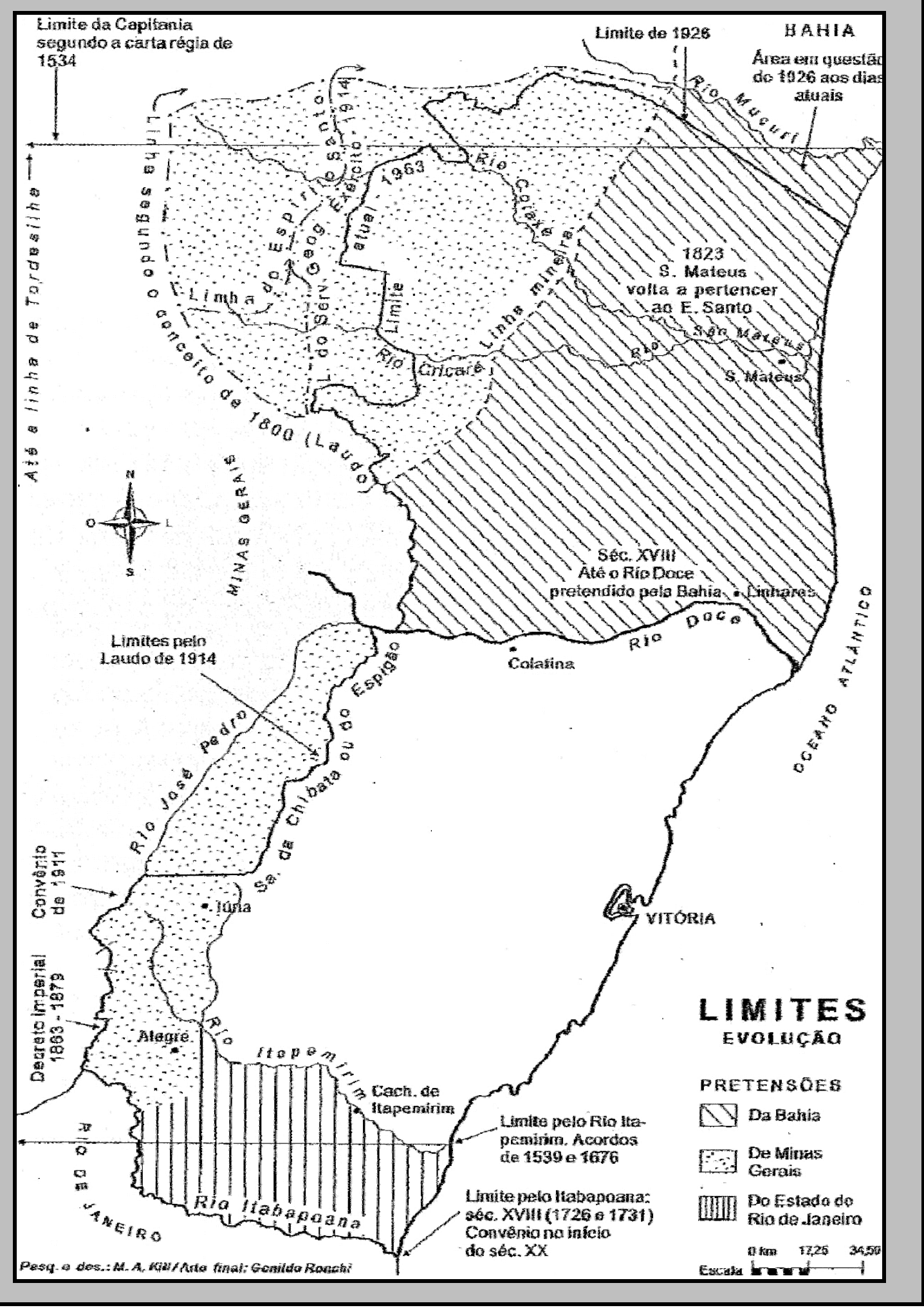

Figura 1. Limites de disputas territoriais entre Bahia, Minas Gerais e Rio de Janeiro para as terras do Espírito Santo. Adaptado de Kill (2005) 
Ao se investigar a cartografia do século XIX, verifica-se que apesar dos avanços tecnológicos quanto à representação gráfica, a região entre Minas e Espírito Santo não era detalhada. Saint Hilaire (1974, p.55) ainda descreve que "quanto às nascentes do Rio Itapemirim, parece que se não as conhece ainda. Do lado de cima da vila, as pirogas podem subir esse pequeno rio no espaço de, mais ou menos, oito léguas, mas, a partir daí, são detidas, quer por quedas d'água quer por cascatas". Ele se refere à área denominada proibida, onde a divisa entre Minas Gerais e Espírito Santo ainda era indefinida. A ausência de ocupação e povoamento em grande parte do interior do Espírito Santo é decorrente da proibição que constava no Real Erário $^{3}$ português, de 18 de novembro de 1773, referente à abertura de caminhos junto ao Rio Doce e Cuité que levassem Minas ao litoral. Tal condição evidencia a política oficial para a ocupação da região.

Entretanto, a sociedade portuguesa daquele momento estava vinculada a interesses diversos, e muitas vezes, a determinação régia não continha o ímpeto dos desbravadores do Sertão, que também em muitas das vezes eram "fora da lei". Além disso, a fiscalização dessas áreas longínquas era deficiente, o que gerou nesse processo inúmeras restrições oficiais à penetração dos sertões do leste, tendo a Administração Portuguesa emitido ordens, onde se proibia qualquer tipo de comunicação terrestre entre as Minas e a capitania do Espírito Santo em 1704, 1710 e 1733, conforme afirma Costa (2004).

Em 1800, os portugueses iniciaram um processo ativo de demarcação dos limites entre Minas e Espírito Santo, visando estabelecer jurisdições fiscais para a cobrança de impostos. Tinham como objetivo implantar a comunicação dos correios e o estabelecimento de quartéis, tudo de acordo com as ordens reais. Conforme relatório do tenente-coronel Ignácio Pereira Duarte Carneiro, apresentado ao governador da capitania do Espírito Santo, Francisco Alberto Rubim, em 1819, a estrada tinha origem na Cachoeira do Rio Santa Maria no Espírito Santo e seguiria para Minas por rota definida, passando por: Cachoeira do Rio Santa Maria, Quartel

\footnotetext{
${ }^{3}$ O Erário Régio, também chamado de Real Erário, Real Fazenda, Tesouro Público ou Tesouro Geral, foi criado em Portugal pelo alvará de 22 de junho de 1761 e no Brasil pelo decreto de 11 de março de 1808, quando foi nomeado seu presidente, Dom Fernando José de Portugal, que exerceu o cargo juntamente com o de ministro e secretário de Estado dos Negócios do Brasil e o de ministro assistente do despacho do Real Gabinete (www.arquivonacional.gov.br, 2012).
} 
de Bragança, Quartel do Pinhel, Serra Grande (dos Aimorés), Quartel Serpa, Quartel de Ourem, Quartel de Barcelos, Villa Viçosa, Quartel Monforte, Quartel de Sousel, Travessia do Rio Pardo, Rio Guandu, Rio Giquitibá, Rio São Luiz, Quartel Novo, Quartel do Main-assu, Rio Matipo-o, Cabeceira Torta, Quartel Geral da Casca, Ponte Nova, Freguesia do Furquim, Freguesia São Caetano, Freguesia São Sebastião, Cidade de Mariana, Villa Rica (RUBIM, 1844).

As demandas de comunicação entre Minas e Espírito Santo se ampliavam na região deste estado. De acordo com Bravo, (1994, p.9) no início do século XIX:

O alferes João do Monte da Fonseca, comandante da segunda Divisão dos Caçadores de Minas Gerais, foi responsável pela abertura da estrada que de Mariana chegava ao porto de Itapemirim, as margens da qual construiu ranchos para as tropas e quartéis de caçadores, sendo que o último quartel era localizado na foz do riacho, a que denominou de Alegre, junto ao rio Itapemirim, lugar ao qual intitulou Barra do Rio Norte.

Ainda em 1816, o sargento-mor Manoel José Esteves de Lima solicitou ao governo de Minas Gerais, autorização para gerenciar a estrada aberta pela Divisão Militar da Capitania de Minas Gerais, até o rio Itapemirim da capitania do Espírito Santo, prestando apoio aos viajantes e ficando em contrapartida, isento dos impostos sobre os gêneros que neste período de tempo, exportasse pela estrada, conforme Figura 2.

Com o espírito tomado pelas entusiásticas possibilidades de exploração, das terras e outras fabulosas riquezas, encobertas pelas matas do sul da capitania do Espírito Santo, o sargento-mor Manoel José Esteves de Lima organizou, em 1820, uma bandeira de setenta e dois homens que, partindo de Mariana, capitania de Minas Gerais, penetrou nas terras do, hoje, sul do Espírito Santo (BRAVO, 1994, p.13). 


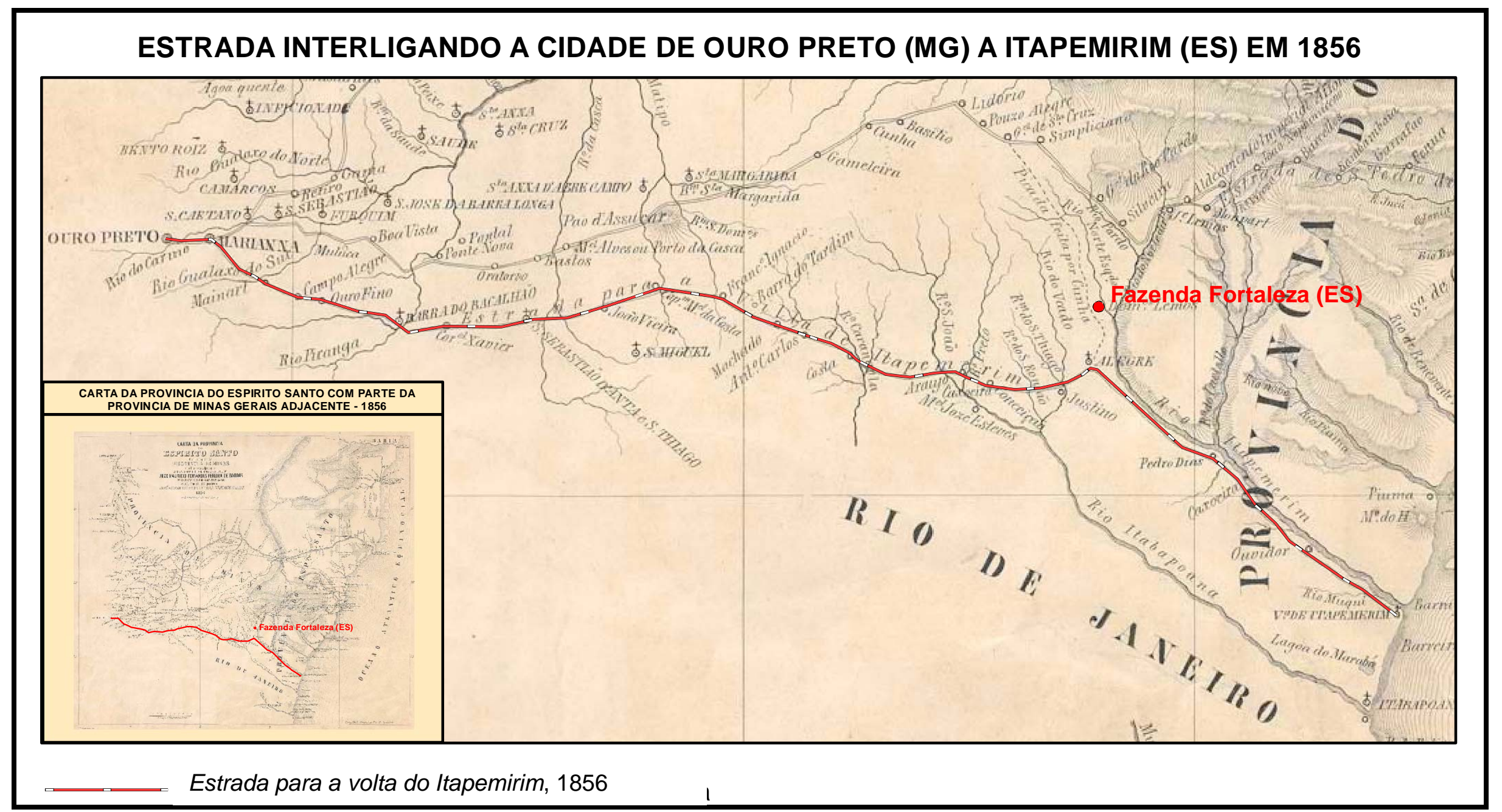

Figura 2. Estrada que foi provavelmente aberta por João do Monte da Fonseca e mantida por Manoel Esteves de Lima no século XIX. 
O objetivo desses mineiros era chegar ao porto de Itapemirim, lá, após serem recebido pelo futuro Barão de Itapemirim, Joaquim Marcelino da Silva Lima, iniciaram a viagem de volta, onde o sargento-mor, Esteves de Lima, foi orientando a fixação de integrantes de seu grupo em diferentes localidades, objetivando a ocupação do território, formando fazendas e ranchos de apoio às tropas (BRAVO, 1994). De acordo com o relatório do presidente da província Vasconcelos (1824), tais colonizadores mineiros tiveram suas posses de terras concedidas em março de 1822. Em 1824, é registrada, na Vila de Itapemirim, a chegada de oito mineiros, dos quais três estavam sob o comando do sargento-mor Manoel José Esteves de Lima. Esses se encontravam a vinte duas léguas de Itapemirim, "fazendo uma grande plantação, por ordem do governo mineiro, com o objetivo de poder concluir a estrada de Minas para o Espírito Santo, e ainda, facilitar o povoamento dos sertões e as minas do castelo" (BRAVO, 1994, p. 17).

A característica da ocupação mineira é visível ao observarmos fotos do início do século XX da cidade de Alegre (ES), e distritos, (Figura 3, 4 e 5) que mostram povoados com ruas definidas pela implantação das edificações, presença de caminhos tortuosos e outros perpendiculares a esses, onde ruas se encerram de fronte uma edificação. Além disso, é possível observar telhados com cumeeira paralela ao alinhamento da rua, casas com paredes em comum na divisão das propriedades, parede e meia e ainda, a presença da ampla praça central tradicionalmente utilizada pelos portugueses para as cavalhadas. A configuração espacial do distrito de Anutiba ilustra organização espacial semelhante à da cidade de Tiradentes (MG), Figura 3: o Largo das Forras, e mesmo à Mariana, com sua praça de dimensões quadráticas.

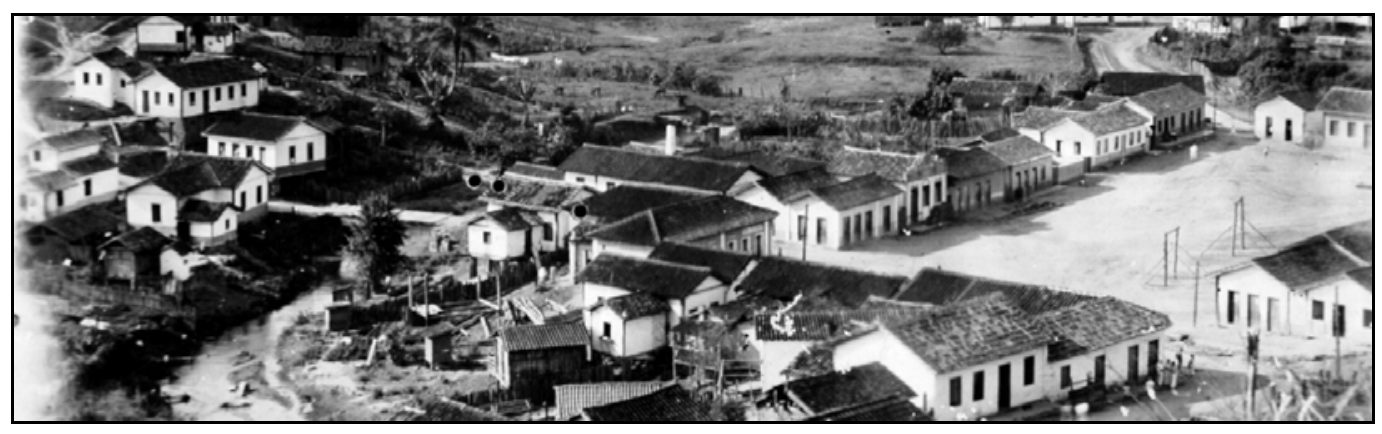

Figura 3. Vista parcial de Anutiba, Distrito de Alegre, ES início do século XX (IHGA, 2010). 
Na região de Alegre, ES, que ocupava boa parte do sul do Espírito Santo, de acordo com Bravo (1994, p.97), os primeiros desbravadores:

eram procedentes das províncias do Rio de Janeiro, Minas Gerais e São Paulo. Eram pessoas das famílias de Paula Mageste, Ferreira de Paiva, Vieira Macedo, Aguiar Valim, Carvalho, Monteiro Nogueira da Gama, Gonçalves de Ataíde, de Paula Ribeiro, Soares da Silva, Coutinho Velasco, Vieira da Silva, Lemos Barbosa, Santos Peixoto, Lacerda, da Costa, Bom Sucesso, de Souza, Monteiro da Silva Porto, Hausman, Amorim, entre outras que aqui chegaram, durante os anos de 1820 e 1860, vindo juntar-se com pioneiros que aqui já estavam.

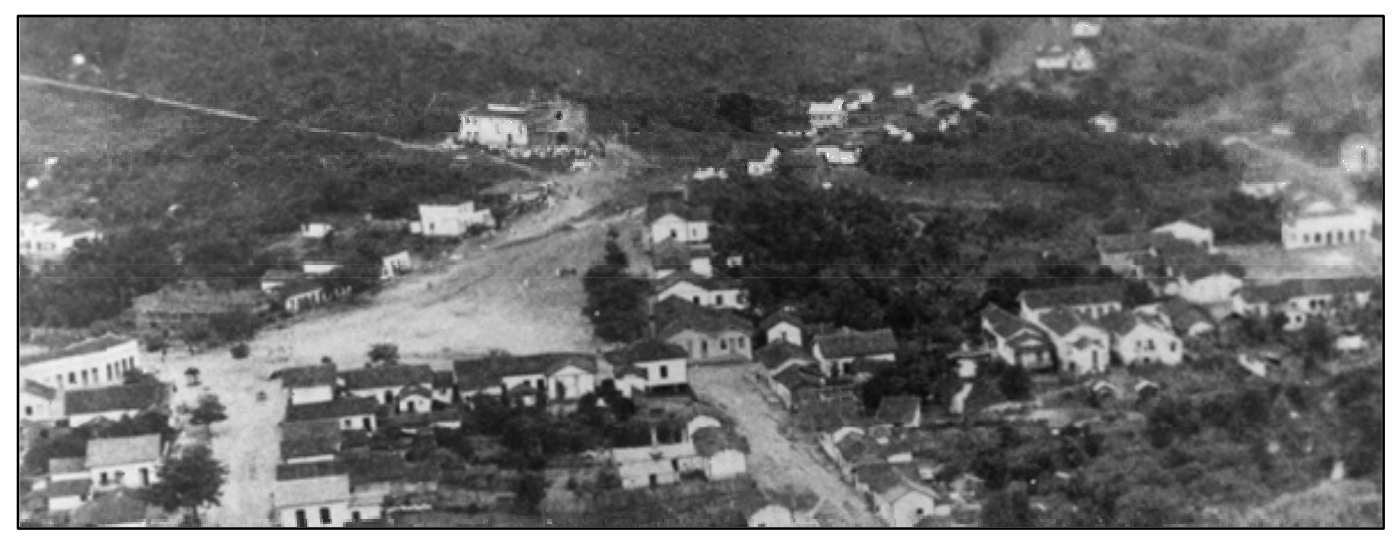

Figura 4. Vista parcial de Alegre, ES início do século XX (IHGA, 2010)

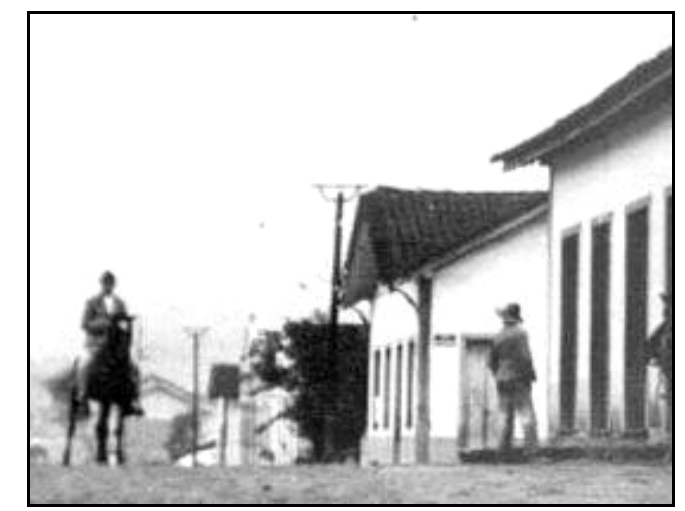

Figura 5. Rua de Alegre, ES início do séc. XX (IHGA, 2010)

Moreira (2002) esclarece que a partir de 1822, com o fim do Regime de Sesmarias, a ausência de leis específicas que regulamentassem a propriedade da terra até 1850 com a Lei de Terras, contribuiu para o processo de apropriação de terras que deu origem a inúmeros latifundiários que compuseram a oligarquia rural 
brasileira. No Espírito Santo, o início da expansão da cafeicultura e ocupação das terras do interior ocorrem nesse mesmo período predominantemente por mineiros, fluminenses e imigrantes europeus.

No recenseamento de 1872, consta que das paróquias instauradas no Espírito Santo, um terço pertenciam à bacia do rio Itapemirim e Itabapoana, conforme ilustra a Figura 6. Sendo as paróquias de: São Pedro do Itabapoana, São Pedro do Cachoeiro, São Miguel do Veado, Nossa Senhora da Penha do Alegre, Nossa Senhora da Conceição do Aldeamento Afonsino, São Pedro de Alcântara do Rio Pardo, Nossa Senhora do Amparo do Itapemirim. Atualmente representadas pelos municípios de Mimoso do Sul, Muqui, Cachoeiro do Itapemirim, São José do Calçado, Alegre, lúna, Itapemirim, e outros municípios que destes se desmembraram (NETO, 2009). Evidencia-se que no final do século XIX, o interior do Espírito Santo ainda era pouco ocupado, com destaque para a bacia do rio Itabapoana e bacia do rio Itapemirim que abrigam freguesias. Até mesmo a bacia do rio Jucu e bacia do rio Santa Maria, que deságuam na baia de Vitória, nesta época ainda não dispunham de povoações próximas às suas nascentes conforme Figura 6 .

$\mathrm{Na}$ área entre os rios Itabapoana e Itapemirim, evidencia-se a paróquia de Nossa Senhora da Penha do Alegre, São Miguel do Veado, São Pedro do Cachoeiro e São Pedro do Itabapoana, Figura 6. Neste avanço da ocupação do território capixaba, é destacada a determinação da administração de Minas Gerais para a abertura e manutenção de uma estrada de Minas para o porto de Itapemirim (Figura 2). Tal região, ainda denominada como "sertões", possuía grande área colonizada como se pertencesse a Minas Gerais, de acordo com cartografia do início do século XIX. Conforme Bravo (1994, p.17), os limites do sul do Espírito Santo com Minas Gerais "eram bastante incertos, pois a mata densa e os índios bravios mantinham os capixabas na estreita faixa litorânea". Essa condição tende a mudar quando em 1825 é concluída a estrada de conexão entre Minas Gerais ao local de onde hoje está localizada a cidade de Cachoeiro do Itapemirim (Figura 2).

Nessa época [1827], as terras do Alegre e outros municípios vizinhos recebiam proteção do governo mineiro através dos seus soldados e eram colonizadas por homens trazidos pelo sargento-mor do Termo de Mariana Manoel José Esteves de Lima, sendo, então, consideradas solo mineiro, conforme determinava o Auto de Demarcação (BRAVO, 1994, p.19). 


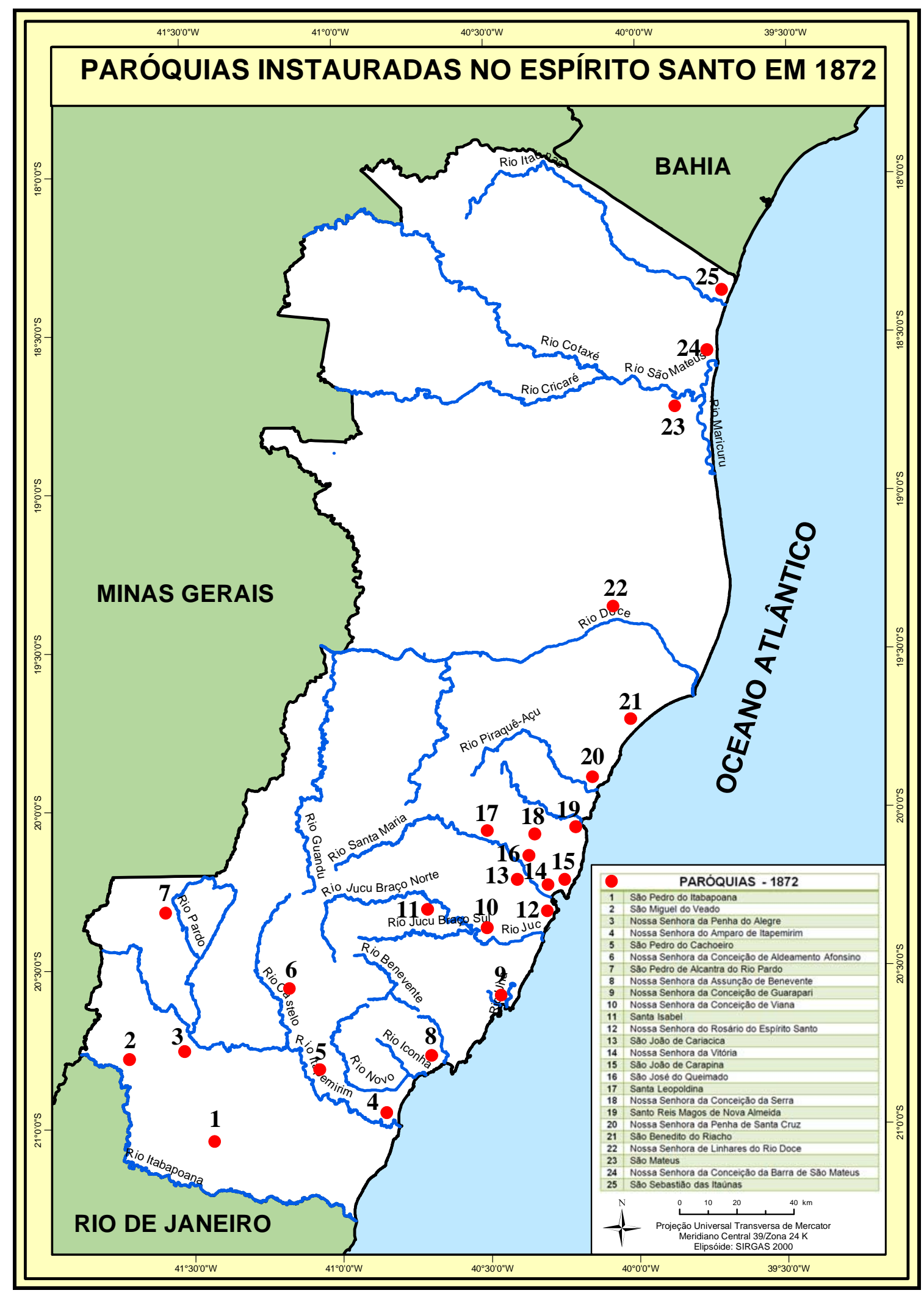

Figura 6. Paróquias que constam no recenseamento de 1872, localizadas no estado do Espírito Santo a partir da hidrografia. Adaptado de Neto (2009). 
Ainda citando Bravo (1994), as caravanas de novos colonos vindos de Minas Gerais traziam os pioneiros da ocupação destas terras, como João Teixeira da Conceição, que plantava e incentivava os novos colonos ao cultivo do café. Com isso, a produção agrícola da região aumentava, crescendo, assim, o movimento das tropas rumo ao porto de Itapemirim.

Neste processo de ocupação do Espírito Santo por mineiros, em 1840, a região de Alegre era composta por municípios como Guaçuí e lúna, que pertenciam a Minas Gerais. A estrada para Minas Gerais era fundamental para o desenvolvimento do sul do Espírito Santo. A via de comunicação com Minas que realmente possuía trânsito era a de Itapemirim a Ouro Preto, apesar da estrada de Santa Tereza, ou estrada do Rubim, ter sido concluída primeiro (NETO, 2009). Todavia, a estrada de Itapemirim a Ouro Preto tinha o trecho de Cachoeiro do Itapemirim ao Porto de Itapemirim em condições precárias de conservação. Isso preocupava as autoridades, sem, contudo comprometer as boas expectativas em relação à importância da estrada para o desenvolvimento da região.

Não espero que por nela sejam transportados os gêneros da lavoura Mineira muito além dos limites desta província. A extensão do caminho, e a circunstancia de não ser a barra de Itapemirim de fácil acesso devem desiludir-nos. Como, porém sejam excelentes os terrenos do Veado, São Pedro de Rates, Alegre e Cachoeira, tornase esta estrada de extrema utilidade e de trânsito frequente porque a emigração Mineira e Vassourense afluem para ali fundando grandes e rendosos estabelecimentos agrícolas (CORREA, 1871, p.93).

Saint-Hilaire (1974, p.108) observa que transitavam neste caminho "pedestres e índios e para que os muladeiros encontrassem durante a viagem víveres e abrigo, havia de colocar, de três em três léguas, soldados que seriam suprimidos logo que os colonos se estabelecessem à beira do caminho". Tais postos militares eram denominados Quartéis, e muitos deles se tornaram fazendas após a consolidação da ocupação dos caminhos (BOTELHO, 1984).

Além disso, dessas fazendas, inúmeras se converteram a ponto de origem para formação de povoados de cidades, que em alguns trechos, com a chegada da ferrovia, teve consolidada a ocupação. Até o final do século XIX, com o surgimento das ferrovias, os caminhos eram estreitos e abertos mata adentro, se constituindo como trilhas ou estradas perigosas e pouco movimentadas. Aqueles que as 
percorriam eram aventureiros e andavam em comboios, principalmente quando transportavam cargas, como faziam os tropeiros. Eram comuns os deslocamentos a pé, em carros de bois, lombos de burros e liteiras conduzidas por escravos. Esse movimento nas estradas exigia pousos, abrigos, postos de abastecimento de negócios e alimentos, que podem ser interpretados como locais pioneiros de inúmeras fazendas e povoados. Diante disso, era comum que os fazendeiros abrigassem viajantes e negociantes, de maneira que os sistemas se interdependiam.

Fazendas foram formadas ainda em decorrência da ocupação de uma nova área resultante das fugas de personalidades oriundas de conflitos políticos, forçando o deslocamento para o Sertão em busca de oportunidades longe da prisão. Deste modo, muitas dessas propriedades seguiram o padrão da tradicional fazenda mineira, composta por cultivo de roças, nem sempre fundadas sob a monocultura. Eram em geral propriedades de pequenas proporções, podendo ter o engenho movido à água ou não, o que determinava a dimensão da fazenda e poder econômico do proprietário, uma vez que grandes propriedades também se formaram. Entende-se que, pela influência mineira, ocorre predomínio de fazendas de produção ampla e diversa. A presença mineira se fez de tal maneira que apenas depois de 1850, o Espírito Santo confirmou suas posses sobre grande parte da região do sul do estado, tendo ainda permanecidas as disputas de divisas, onde a questão dos limites entre os estados foi encerrada apenas no ano de 1963 (COSTA, 2004).

O arraial de Alegre desenvolvia-se com bastante intensidade. Cada vez mais, chegavam colonos provenientes das províncias do Rio de Janeiro de Minas Gerais. A riqueza do cultivo do café e o grande tráfego de tropas levaram à Assembleia Legislativa Provincial a votar, em 13 de julho de 1857, a Resolução $n^{\circ}$. 4, que, sancionada pelo presidente da Província, Olímpio Carneiro Viriato Catão, em 14 de julho, criava, no povoado do Alegre, a sede do quinto Distrito de Paz do município de Itapemirim (BRAVO, 1994, p. 25).

A capitania do Espírito Santo vivia de expressivas limitações. Em 1811, as estradas eram quase inexistentes, e desde o rio Doce até o rio Itabapoana percorriase pela extensa costa do mar (OLIVEIRA, 1975). Em 1824, o governador Ignácio Accioli de Vasconcelos, em ofício ao Ministro do Império, destaca que a província do Espírito Santo "é a mais miserável do Império: não tem agricultura nem comércio, 
seus habitantes são pobríssimos". Tais condições já eram colocadas desde a ampliação das dificuldades impostas pela perda de rendas decorrentes da separação de Campos dos Goytacases e São João da Barra da província do Espírito Santo. Conforme Almada (1984), a situação de miséria do Espírito Santo é agravada pela segregação do "restante do território da capitania de São Tomé, ou da Parayba do Sul, por Lei de 31 de agosto de 1832" que determina a passagem de Campos dos Goytacases e São João da Barra à província do Rio de Janeiro.

Em 1831, já havia dificuldades econômicas devido às limitações do tráfego negreiro que veio a se extinguir em 1850. O desafio do Espírito Santo era grande perante uma agricultura canavieira carente de mão de obra abundante e capital de investimento. Nesse contexto, o café é introduzido na economia capixaba ainda no início do século XIX. Conforme Almada (1984, p.60), a cultura do café se impõe no Espírito Santo em substituição à cana-de-açúcar porque se trata de:

cultura extensiva e exigente de terras virgens [...] e irá valer-se da mão de obra escrava disponível e atrair imigrantes livres e escravos das regiões vizinhas, que aos poucos irão ocupar as imensas áreas despovoadas da província.

A condição da cultura de cana de açúcar e café no estado do Espírito Santo no século XIX pode ser visualizada a partir da análise comparativa entre as Figura 7 e 8. De acordo com relatórios dos Presidentes da Província, na década de 1850, houve a superação da produção da cana de açúcar pelo café, chegando o Espírito Santo na década de 1870, a produção de 560.000 (quinhentos e sessenta mil) arrobas. Na segunda metade do século XIX, mesmo com as dificuldades impostas pelas restrições referentes à eliminação do tráfico de escravos, a produção cafeeira é ampliada no Espírito Santo, assim como a mão de obra escrava. Para o funcionamento de uma fazenda de café, conforme Costa $(1966,27)$ :

os serviços eram contínuos [...], a mata tropical, de sub bosque denso, cheio de liames intrincados de árvores frondosas, precisava ser derrubada. Esse era um trabalho rude e penoso, principalmente numa época em que se dispunha apenas de machado e foices. Depois o preparo da terra, o plantio, as construções, as carpas, as roças onde se cultivava o necessário para sustento das fazendas, o trato dos animais, numerosos então, pois representavam o único meio de transporte disponível. 


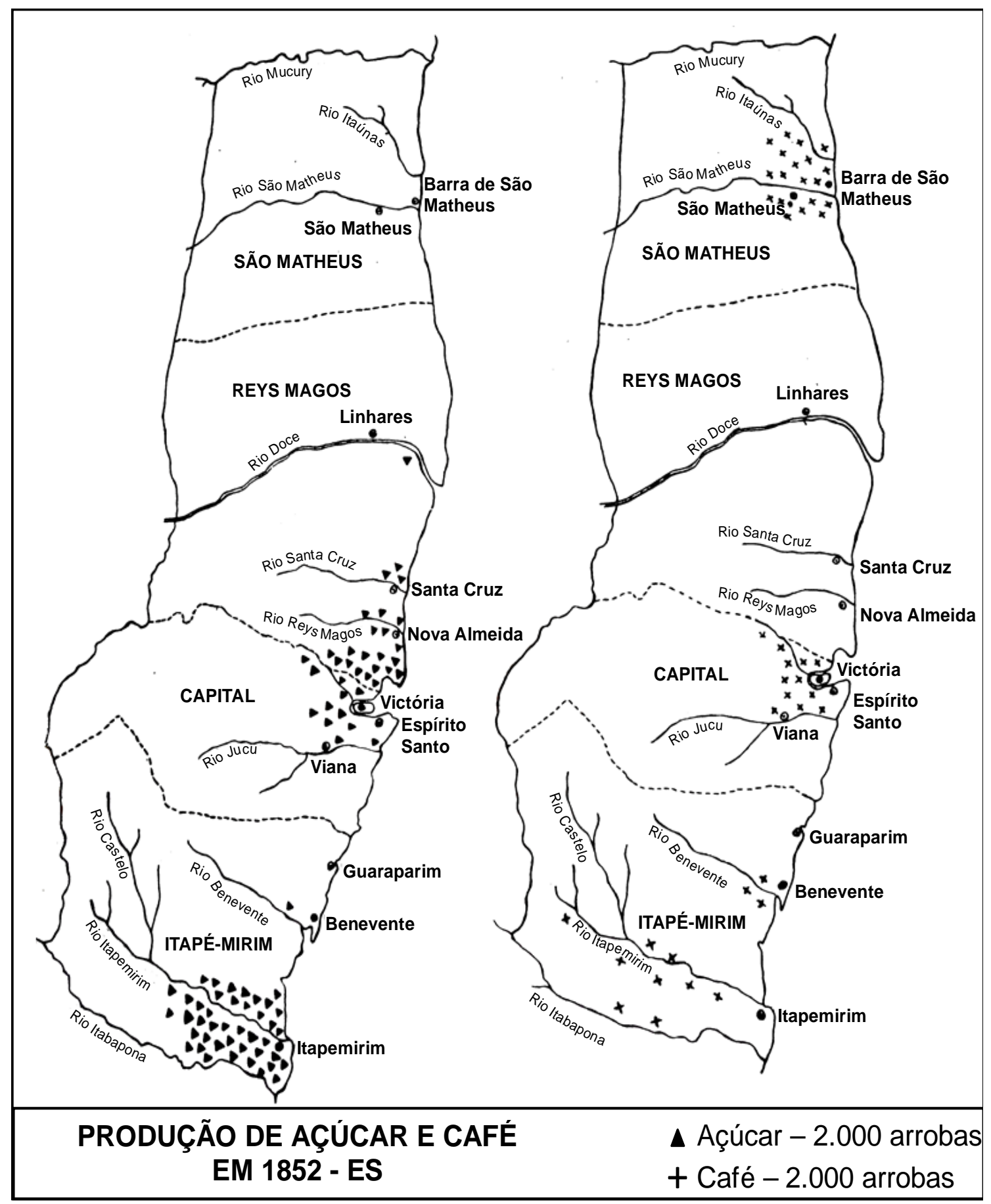

Figura 7. Produção de açúcar e de café em milhares de arrobas para o ano de 1852, adaptado de Almada (1984). 


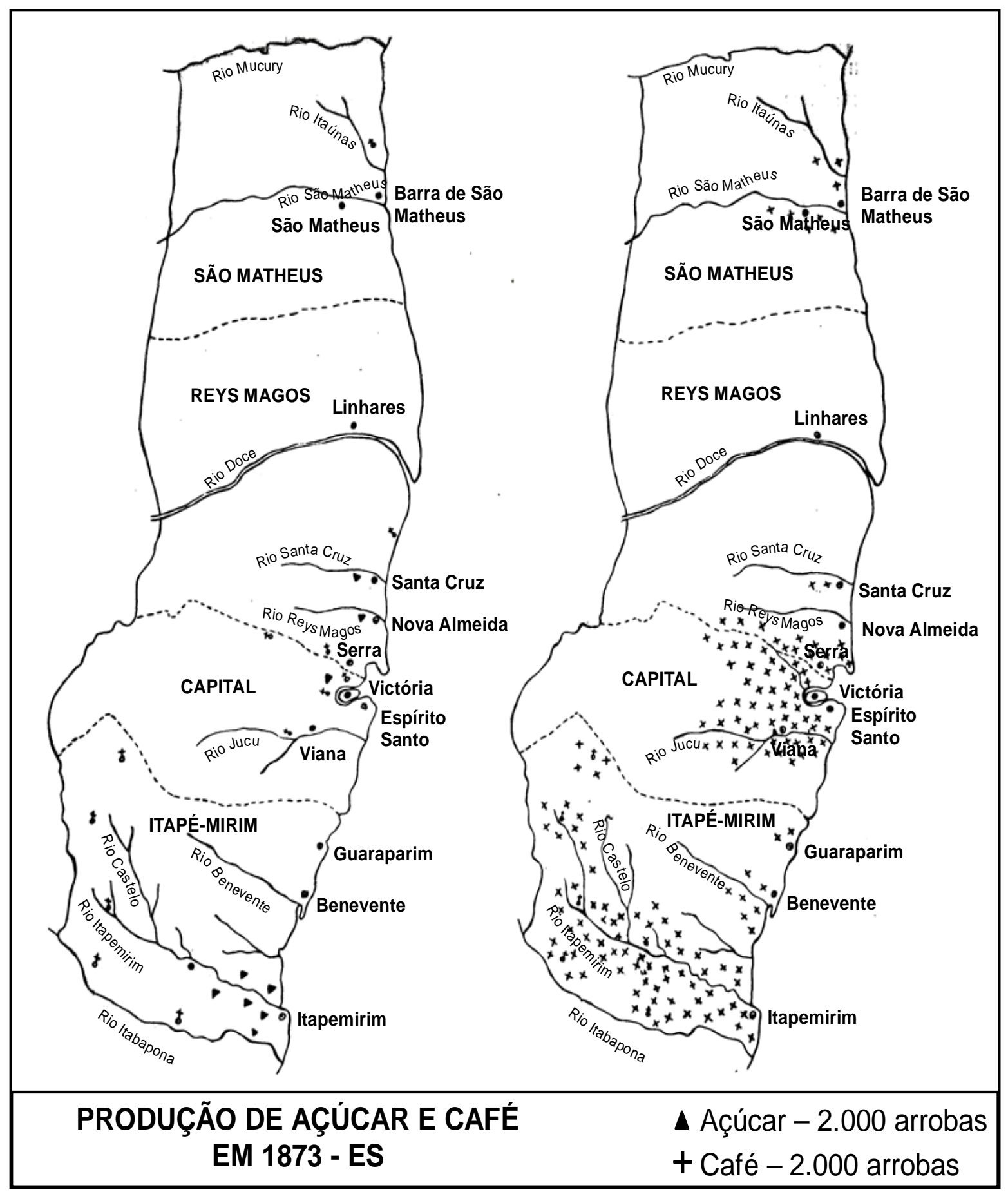

Figura 8. Produção de açúcar café em milhares de arrobas em 1873, adaptado de Almada (1984). 
Cabe destacar que por volta da década de 50 do século XIX ocorreram mudanças marcantes na estrutura econômica do Espírito Santo e elas exerceram importante contribuição na atual configuração do estado. Nesse período, o cultivo do café se expandiu, tornando-se a principal atividade agrícola regional, substituindo a produção da cana-de-açúcar e transferindo para o plantio do café o trabalhador escravo, então utilizado no cultivo açucareiro. Houve uma mudança na configuração da dinâmica regional, veja a Figura 7 e 8 . 0 café foi plantado em todas as regiões, mas a partir de 1870, a produção concentrou-se principalmente no sul do estado, região de Cachoeiro de Itapemirim. Conforme Daré (2010), a região sul possuía grandes fazendas de café, já a região de Vitória apresentava estrutura fundiária basicamente formada por pequenas propriedades e agricultura de subsistência.

De acordo com relatório do presidente da Província José Fernandes da Costa Pereira Júnior, à Assembleia Legislativa Provincial, em 1862:

Em Itapemirim existem mais de quarenta excelentes fábricas de açúcar, algumas das quais têm máquinas a vapor, ao mesmo tempo que, no Cachoeiro e no Alegre prospera o café, cuja produção em todo o município pode ser orçado em mais de 200.000 arrobas, e vai crescendo todos os anos (JUNIOR, 1862, p. 28).

Em Alegre, o distrito denominado Café, retrata esta condição de importância da cafeicultura na região. Possui inúmeras fazendas de grande porte ainda remanescentes deste período. A fazenda Boa Sorte, apesar de pequenas modificações arquitetônicas, mantém preservadas as referências de sua origem agrária, conforme Figura 9.

No recenseamento de 1872, verifica-se que Alegre era bem desenvolvido, com população expressiva livre e de escravos. Mesmo com a abolição da escravatura, as atividades agrícolas da cafeicultura progrediram em decorrência do solo fértil das matas recém derrubadas. Nesse contexto, os trabalhos para fazer chegar a estrada de ferro à sede da vila do Alegre eram contínuos.

O presidente da província, em 16 de setembro de 1887, realizou viagem inaugural da estrada de ferro, que ligava Cachoeiro de Itapemirim à estação do Pombal (Rive) [distrito de Alegre. Foi um acontecimento importantíssimo para o desenvolvimento da região sul capixaba] (BRAVO, 1994, p.33). 


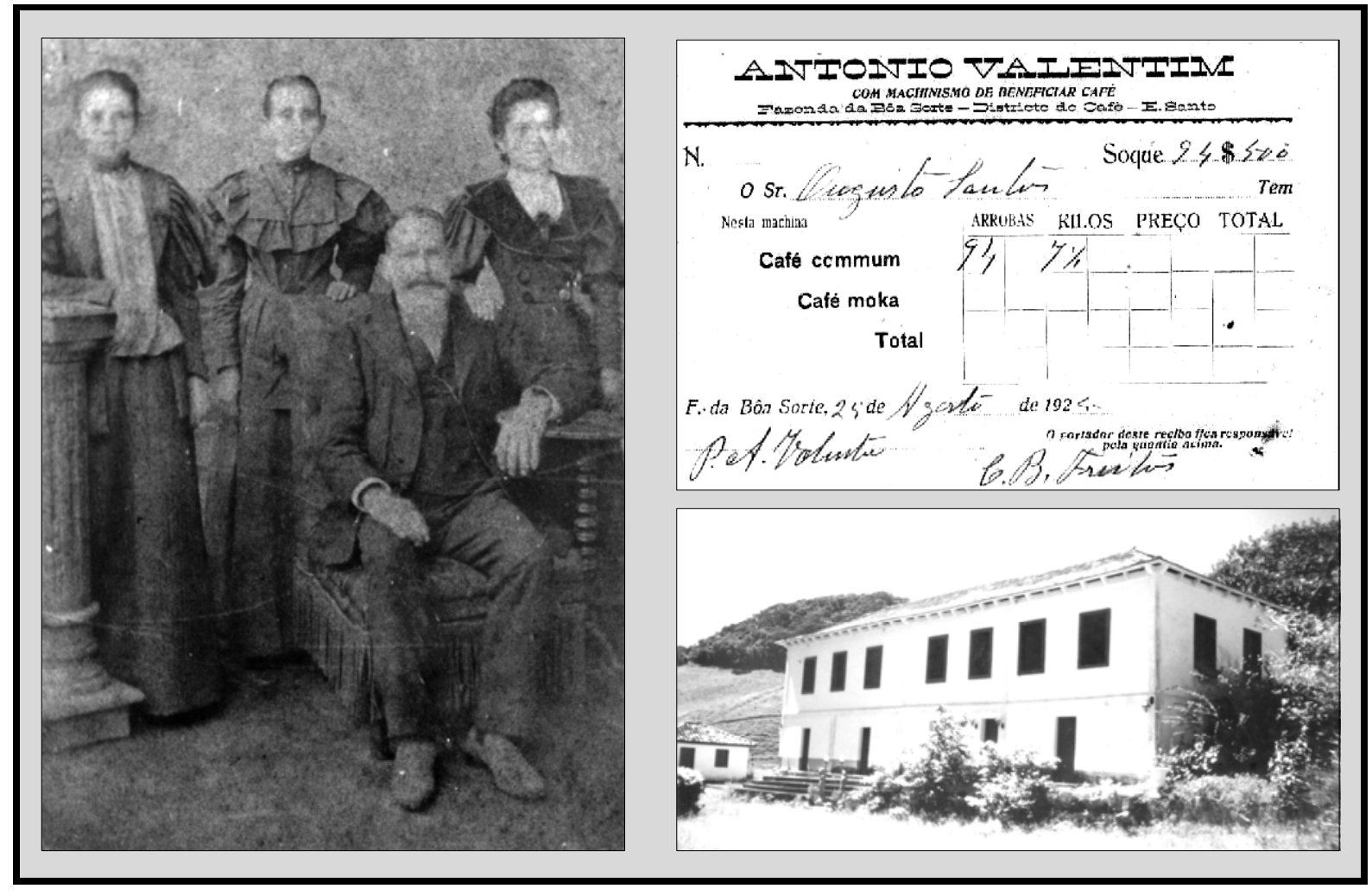

Figura 9. Proprietários; documento de movimentação cafeeira e vista da sede da Fazenda Boa Sorte, Distrito do Café, Alegre (ES), (IHGA, 2010).

Mesmo considerando as pressões econômicas e políticas existentes na segunda metade do século XIX no Brasil, acredita-se que a ocupação recente do território capixaba possibilitou avanços para a expansão agrária e urbana. Nessa estrutura histórica e econômica, percebe-se a ampla interseção entre o universo mineiro e capixaba, com destaque para a região sul do estado, uma vez que ao norte, os interesses baianos predominavam, apesar de mineiros tradicionalmente terem pleiteado terras na região.

Esses mineiros que se fixaram no território sul capixaba instalaram fazendas, que tiveram papel importante tanto na organização econômica, como política e social do espaço. Os primeiros empreendimentos rurais que se formaram entre os vales dos rios Itapemirim e Itabapoana aconteceram em situações de 
desbravamento de áreas de mata densa. Conforme Werneck (1878), muitas vezes a escolha do sítio para implantação da sede de uma fazenda estava vinculada às espécies de árvores do local, que indicavam qualidade da madeira e fertilidade do solo. A madeira retirada da derrubada da mata atlântica foi muito utilizada em ambientes rurais, compondo elementos diversos na aplicação agrícola, tais como engenhos, depósitos, edificações para o criatório de animais, instrumentos de trabalho como ferramentas, o mobiliário e as edificações em geral. A dinâmica econômica definiu significativamente a arquitetura e seus condicionantes. $O$ tipo de atividade e sua escala de produção se relacionam intimamente na definição de tipologias arquitetônicas, assim como os materiais utilizados nesses complexos rurais estão atrelados a parâmetros culturais diversos.

Para compreender a arquitetura e sua técnica construtiva, é necessário conhecer as condições em que foram realizadas. Em se tratando de complexos edificados em ambientes rurais, cabe destacar o significado da arquitetura a que se refere de acordo com a região em que se manifesta. Para Cardoso (1975), o conceito de arquitetura contempla "o de espaço útil, limitado artificialmente e animado por uma arbitrária disposição de formas imitadas da natureza ou criadas pela imaginação"; para ele, na arquitetura civil, prevalecem o gosto popular e coletivo, diferentemente das obras grandiosas como os monumentos religiosos. Há que se considerar o edifício "como uma figura de um campo definido e limitado", onde é necessário conhecer a "estrutura interna desses campos, para caracterizar esses domínios pelas suas diversas condições de natureza, de técnica ou de cultura, de definir os seus limites e de classificá-los". Essa ideia de "campo" colocada por Cardoso (1975) evidencia o objeto arquitetônico em sua totalidade, considerando todo o complexo que o constitui.

O clima, a exploração agrícola e a localização geográfica compõem elementos que contribuem para o conhecimento das características da casa rural de regiões diversas. Os núcleos rurais que historicamente se constituíram no Brasil em diferentes regiões estão marcadamente vinculados à dimensão econômica e territorial da agricultura, como os engenhos de açúcar e as fazendas de café paulistas. Cardoso (1975) destaca as características da arquitetura rural brasileira, exemplificando a região do Alentejo em Portugal, onde as dependências em que se armazenavam as alfaias agrícolas, onde se faziam o queijo e o pão e onde repousa 
os serviçais, os malteses e o gado, concebem um tipo de construção adaptada às grandes propriedades rurais, representando uma formação social semelhante a dos latifúndios brasileiros. Esclarece que as características de determinada arquitetura rural estão estreitamente ligadas às condições de apropriação da terra, às dimensões de tal área e à cultura que congrega aquele que a ocupa e que a edifica.

Cabe destacar ainda que conforme Lemos (1989, p.13), no Brasil, "as condições socioeconômicas e o clima determinaram plantas, agenciamentos e partidos arquitetônicos peculiares", assim como o encastelamento das classes dominantes em latifúndios, condicional a alocação de grande parte do resto da população nas cidades (LEMOS 1989).

Diante deste tradicional latifúndio, onde a pequena propriedade se faz sobre suas bases, conforme nos esclarece Guimarães (1989), ou a partir da propriedade que surge com a imigração estrangeira no sul do Brasil e Espírito Santo, conforme aponta Petrone (1984), evidencia-se a caracterização arquitetônica distinta, apesar de não se excluir questões comuns. Tendo como referência a estrutura fundiária, vislumbram-se os condicionantes que definem determinada tipologia arquitetônica, assim como a relação de tal forma de construir como inerente à origem social do proprietário da terra que a edificou, conforme seu poder econômico, referência cultural, e dimensão da área rural. Essa questão traz junto de si, o tipo de agricultura que é adotada na propriedade como itens de influência significativa no padrão construtivo de suas dependências e complexo agrário.

Considera-se interessante entender questões relacionadas à estrutura fundiária brasileira como auxílio à compreensão dos diferentes padrões da arquitetura rural, assim como do sistema construtivo adotado. Ao se observar a arquitetura oitocentista do sul do Espírito Santo, percebe-se que a região historicamente se fez a partir da ocupação das fazendas de café que se expandiram do norte do Rio de Janeiro e sudoeste de Minas Gerais, assim como por imigrantes europeus do final do século XIX que se fixaram na região. Apesar de a ocupação ter iniciado no litoral do Espírito Santo ainda no século XVI, ela não se expandiu para o interior nos primeiros séculos de colonização.

Como forma de defesa, para impedir a penetração no território das Minas Gerais, até fins do século XVII não houve interesse oficial em desenvolver e povoar o território compreendido entre o sul da Bahia 
e o norte do Rio de Janeiro, a estreita faixa de terra entre o mar e as montanhas, que constitui atualmente o estado do Espírito Santo (MUNIZ, 1997, p.29).

A ocupação se deu a partir da abertura dos caminhos e da realização do povoamento das terras capixabas, como resultado de esforços efetivados a partir de 1810, quando o território do Espírito Santo se tornou independente da Bahia, e passou a ter governo próprio, conforme afirma Oliveira (1975). A ocupação das terras no Espírito Santo ocorreu a partir de sesmarias e disso resulta uma formação que tem suas bases no latifúndio, mas também, na pequena propriedade, já que "a imigração europeia foi, sem dúvida, a solução mais eficaz para o povoamento das terras do Espírito Santo" como descreve Muniz (1997).

Guimarães (1989) destaca a condição de formação do latifúndio no Brasil assim como o surgimento da pequena propriedade, tendo como destaque suas origens com os posseiros e intrusos, além dos agregados nas grandes fazendas. Esse autor analisa os quatro séculos de latifúndio no Brasil, como luta das camadas empobrecidas na busca pela propriedade da terra; como processo histórico em que surge e se mantém o latifúndio, e como é estruturada a sociedade que permite a existência deste sistema de propriedade da terra.

No que se refere à presença dos imigrantes na formação do território, "italianos e outros imigrantes muitas vezes se contentavam com a possibilidade de adquirir um lote em fazenda de café abandonada, onde o esgotamento do solo impunha o retalhamento da terra" (PETRONE, 1984). O fazendeiro abria novas fazendas e mantinha a sua volta colonos que compravam as antigas terras com algum dinheiro adquirido em trabalho desenvolvido para o referido fazendeiro. Apesar de o latifúndio prevalecer com o avanço da imigração, que garantiu o seu fortalecimento, foi acompanhado ao longo do século XIX do crescimento da pequena propriedade com suas implicações sociais e econômicas.

Considera-se importante entender que intrusos e posseiros representaram os percussores da pequena propriedade. Inicialmente, conforme Guimarães (1989) nos esclarece, as invasões aconteciam em sesmarias, em terras de ninguém, ou assim entendida, depois nelas próprias, quando abandonadas ou não cultivadas e posteriormente se direcionaram para as terras devolutas. Almada (1984) esclarece 
que ocorreram inúmeras situações que o governo em seu processo de legitimação de terras no Espírito Santo, regulamentou propriedade de terras de particulares, ocasionando graves demandas legais de dupla propriedade. A posse nem sempre se voltava à formação de pequenas propriedades, uma vez que possibilitou ainda a configuração de inúmeros latifúndios (GUIMARÃES, 1989, p.113). Essa condição é observada na Fazenda Fortaleza, Alegre (ES), quando da regulação da posse da terra por meio do processo de terras na segunda metade do século XIX (INSTITUTO DE DEFESA AGROPECUÁRIA E FLORESTAL DO ESPÍRITO SANTO, 1924).

Em 1822, com a abolição da Sesmaria, ampliou-se a dificuldade de manutenção do latifúndio para o lavrador sem recursos. Contudo, foram mantidas as doações públicas das terras que eram convertidas em latifúndio, mas ainda assim permaneceram as ocupações de lotes menores. Foi a partir desse momento, conforme Guimarães (1989), que a ocupação tomou importante posição diante das concessões do poder público. Nesse momento de expansão territorial, a fiscalização pública era deficiente e a posse da terra ocorria ainda com frequência (LINHARES, 1981). A imigração europeia trazia o fomento à pequena propriedade, e, além disso,

o imigrante europeu instalado em pequena propriedade, deveria constituir-se no agente modernizador e transformador da sociedade e da economia brasileira. Com experiências agrícolas e de criação de gado diferentes, com técnicas artesanais novas, com hábitos de vida outros que os das populações existentes, esperava-se que o imigrante contribuísse para tirar o país da situação de atraso a que o sistema colonial o tinha relegado (PETRONE, p.18).

Esse ponto de vista pode não ser majoritário, entretanto ele nos indica evidências ainda no campo das ideias e da efetiva diferenciação que ocorre na forma de habitar e edificar ambientes rurais de pequena extensão, se comparados com aqueles da grande fazenda no Brasil. Isso pode se mostrar a partir da casa residencial do imigrante italiano e alemão, comparada à casa do brasileiro já radicado no país a partir da colonização portuguesa, principalmente o mineiro, para o caso capixaba. A tradição em se cultivar a terra e a maneira como se relacionam os povos que nela trabalham e plantam, refletem diretamente na tipologia arquitetônica e no sistema construtivo do complexo agrícola que esses agricultores instalam em suas propriedades rurais. 
De maneira geral, percebe-se que a ação do imigrante tornou terras cultiváveis, tanto aquelas esgotadas como as que foram desbravadas, possibilitando a construção de estradas, pontes e infra-estrutura, trazendo maior valorização às terras com custo baixo frente aos interesses fundiários. Essa realidade revelou a estrutura de ocupação do espaço com dependências e sistemas sociais marcados pela forma de edificação do espaço, retratada pela arquitetura em condições diversas no Brasil. Nessa situação, escravos receberam terrenos para levantar a própria casa e condições para mantê-la, além de área para quintais, pomares, e roça. Cada sítio tinha a forma de uma povoação, uma vez que para os senhores, os escravos se tornavam vizinhos (LINHARES, 1981). Em tais condições, o sistema construtivo e as características das construções, nesses complexos, foram distintos, mesmo sem a clareza de seus detalhes. A casa do senhor e a do escravo se fizeram com dimensões e padrões construtivos diferentes. Tal condição da terra e de seu cultivo contribuiu significativamente para a apreensão das condições e escolhas arquitetônicas adotadas e implementadas por determinados grupos agrícolas.

Ao pesquisar sobre a ocupação do sul do estado do Espírito Santo, que além da região entre os vales do Itabapoana e Itapemirim, congrega os vales do rio Novo, rio Jucu, Santa Maria, assim como parte do rio Doce, observou-se a ampla diversidade de grupos que se instalaram na região. "Os colonizadores mineiros, tiveram suas posses de terras, concedidas pela portaria de 13 de março de 1822, da Secretaria de Estado dos Negócios do Reino" (BRAVO, 1998) e representam a maioria absoluta dos migrantes brasileiros no estado do Espírito Santo (KILL, 2005). Cabe lembrar que no início do século XIX, com a divergência na demarcação das divisas entre Minas e Espírito Santo, parte da região sudoeste do Espírito Santo, pertencia a Minas Gerais. Essa realidade de administração da propriedade reflete nas condições de ocupação da terra. Nessa região, prevaleceu a ocorrência de fazendas de policulturas, de café e de gado, fundadas após o declínio das catas auríferas em Minas.

Em outros municípios da região sul do Espírito Santo, mantiveram-se as fazendas cafeeiras, mas com influência do Rio de Janeiro, representando a ampliação da ocupação do Vale do Paraíba, como é o caso de Mimoso do Sul e Muqui. Em outras áreas, como do Benevente, prevaleceu a colônia e a pequena propriedade do imigrante europeu do século XIX e XX, que apesar de cultivar café, 
tinha como padrão construtivo para suas edificações referências distintas daqueles oriundos de outras regiões do Brasil. Cabe destacar que a arquitetura é um fenômeno eminentemente cultural e a mensuração das interações entre diversas influências tipológicas ambientais é complexa. Entretanto, os aspectos de valores e modos de vida em um novo ambiente a ser edificado favorecem o juízo entre as interligações culturais do grupo social que o constrói. As características construtivas próprias no estado do Espírito Santo são resultados das especificidades de sua ocupação, ou seja, ataques indígenas, restrições de exploração aurífera, obstáculos geográficos, como montanhas ao sudoeste e áreas pantanosas junto o rio Doce, tornaram a ocupação do interior do estado tardia.

Após 275 anos de colonização, em 1810, índios ainda atacavam Carapina, a $10 \mathrm{~km}$ de Vitória, e, por isso, não havia agricultura no Estado a mais de $20 \mathrm{~km}$ do mar (KILL, 2005, p.27).

O autor ainda esclarece que, se comparado ao processo migratório no Espírito Santo, a contribuição dos mineiros é majoritária, e que no que se refere à imigração, foram os italianos os de maior número, chegando a $80 \%$. E ao se considerar a presença da imigração europeia no estado, registra-se, atualmente, que mais da metade dos capixabas são descendentes de europeus (KILL, 2005). Essa ocupação partiu de áreas rurais e a marca cultural do imigrante na paisagem e na sua arquitetura é consideravelmente visível. Muitos europeus, de tradição rural, distribuíram-se em colônias familiares e permaneceram no campo até os dias atuais, cultivando produtos hortifrutigranjeiros e também o café. Muitos deles, como os germânicos, ainda conservam em suas casas as tradições dos primeiros imigrantes (MUNIZ, 1989). Mesmo com a expressiva ocorrência do latifúndio no Espírito Santo, a presença da pequena propriedade foi considerável, tendo em vista a ocupação ao longo do século XIX sob a ótica do sistema de colônias para o imigrante europeu. No estado, alguns imigrantes, principalmente italianos tiveram acesso às fazendas, mas a maioria deles se fixou a partir do trabalho familiar e da policultura em propriedades pequenas e fazendas latifundiárias.

A arquitetura fez-se como resultado de tal organização produtiva. De acordo com Posenato (1997), a construção do complexo agrícola contemplava uma casa ampla, com cozinha espaçosa para as refeições e convívio; a construção de abrigos para os animais domésticos e para os implementos agrícolas; depósito para os 
mantimentos e para o que fosse produzido no lote; edificações de edículas para as instalações domésticas de apoio e para os equipamentos de processamentos da produção; e ainda os espaços abertos ou cercados como terreiro, horta, pastagens e plantações.

É interessante destacar ainda que a partir de 1888 a entrada de imigrante no Espírito Santo foi dirigida paras as fazendas, e muitos se mantiveram como meeiros, mantendo a organização dessas estruturas. Contudo, conforme Posenato (1997), em algumas situações, os fazendeiros estavam com dificuldades em substituir a mão de obra escrava, vendendo suas fazendas a grupos de imigrantes. Muitas dessas propriedades foram loteadas para pastagens e plantações, como é o exemplo da Fazenda Lavrinhas em Venda Nova do Imigrante (ES). Entretanto, há registro de italianos que se tornaram fazendeiros, mantendo o sistema produtivo e de acúmulo de capital baseado no latifúndio. No processo de ocupação da terra, ocorreu no Espírito Santo situação de apropriação de algumas propriedades de posseiros que ocupavam a terra a várias gerações, por usurpação, por meio da força bruta, por imigrantes europeus, que os mataram para ficar com a posse (POSENATO, 1997, p.290). Nesse universo do saber histórico do processo de ocupação do espaço rural, onde conhecer a estrutura fundiária auxilia no conhecimento da organização arquitetônica e do sistema construtivo das instalações agrárias, Posenato (1997) destaca que:

em comparação com a estrutura do lote colonial, à maior extensão territorial da fazenda corresponde um núcleo arquitetônico igualmente mais avantajado: a casa "grande" do proprietário e as casas dos empregados, e edificações destinadas à guarda dos equipamentos e colheitas, proporcionalmente maiores que aqueles das pequenas propriedades. Muitas vezes há instalações de porte para beneficiamento de produtos, especialmente 0 café (POSENATO, 1997, p.291)

Por ser o Espírito Santo um estado com pequena extensão territorial, se comparado com outros brasileiros, esta condição da formação e ocupação do território capixaba se torna peculiar. Há uma influência direta da cultura lusobrasileira, principalmente mineira, com a europeia, destacando-se a italiana e germânica. A ocupação do sul do Espírito Santo é peculiar e diversa, possui fortes influências da estrutura agrária norte fluminense por meio da tradicional fazenda cafeeira do Vale do Paraíba, da cana de açúcar de Campos dos Goitacazes, assim 
como a expressiva presença de mineiros oriundos das regiões auríferas da área central de Minas Gerais, com costumes da monocultura do café, mas tradicionalmente policultores. Esses migrantes trouxeram ao Espírito Santo a estrutura do latifúndio e da exploração, da ocupação em vasta extensão territorial. A eles se juntaram os imigrantes europeus com o propósito de reforçar o sistema latifundiário e programar a pequena propriedade, que se constituiu em número expressivo. Acredita-se que o complexo arquitetônico do latifúndio é distinto daquele da pequena propriedade, resultando em elementos construtivos diferentes e sendo consequência de um modo de edificar de culturas diversas, neste caso, luso brasileiras, com italianas e germânicas, que produziram no Espírito Santo uma arquitetura com elementos únicos, se comparados àqueles de onde seus construtores vieram. Tudo isso nos leva a identificar a importância do patrimônio rural no Espírito Santo, e tendo os mineiros destacada contribuição na ocupação e formação do espaço, considera-se relevante investigar através da arquitetura rural a sua presença na formação do território capixaba.

Como amostragem, optou-se pela área compreendida entre os vales dos rios Itapemirim e Itabapoana como elegível a esta pesquisa, tendo em vista a expressiva influência de mineiros em sua ocupação, elegendo para estudos detalhados a Fazenda Fortaleza, Alegre, ES. Acredita-se que esta área representa a região mais importante de cultura cafeeira ao logo do século XIX e início do XX no estado do Espírito Santo, conforme Almada (1984). Além disso, sua conformação difere daquela do norte que possui relação territorial direta com a Bahia, e é distinta da ocupação do centro do estado do Espírito Santo, que possui forte influência cultural dos imigrantes europeus do final do século XIX. É também singular se comparada com a cultura rural do litoral capixaba que possui característica de ocupação diferente daquela do interior do estado, tendo em vista as origens da formação do território brasileiro. Entender a edificação e sua organização espacial auxilia a compreensão da arquitetura tradicional. A subdivisão dos cômodos e análise da forma como eles se relacionam contribui para a investigação dos antecedentes construtivos evidenciando tipologias e apontando precedentes arquitetônicos e de desenvolvimentos regionais e suas inter-relações. Assim, para entender a arquitetura da região sul capixaba concebida pioneiramente por mineiros, optou-se por incorporar nos estudos a noção da arquitetura rural de Minas Gerais. 


\subsection{Arquitetura entre os vales do Itabapoana e Itapemirim}

Estudos desenvolvidos por Gonçalves (2008) mostram que em processo crime datado de 1839, o mineiro e desbravador do sul do Espírito Santo, Manoel Esteves de Lima, aparece como autor, movente de ação, contra invasores de suas terras, que segundo ele, nelas construíram "um rancho com esteios que servisse de pousada aos trabalhadores, feito caminho e pontes e roçado, derrubada para três quartas ou um alqueire de plantas de milho..." (GONÇALVES, 2008, p.70), colocaram abaixo as benfeitorias erguidas, sem poupar nem mesmo as duas pontes e o roçado. No processo consta ainda que:

além de proprietário de engenho de cana, movido a água, Manoel Esteves compunha, juntamente com outros sediciosos, o grupo de proprietários da típica fazenda mineira cuja diversificação era uma marca destacada, cultivando o milho e outros gêneros de subsistência e desenvolvendo atividades criatórias (GONÇALVES, 2008, p.72).

Tais dados de uma fazenda mineira pertencente a um desbravador de terras capixabas, leva à necessidade de maior compreensão desta realidade edificada para melhor entender o universo rural do sul do Espírito Santo. Assim, em análise da tipologia arquitetônica rural mineira, Carvalho (2003), em sua investigação referente a fazendas dos séculos XVIII e XIX na região central de Minas Gerais, destaca que as sedes das edificações rurais construídas no século XVIII apresentam plantas quadráticas ou retangulares, com telhados de quatro águas, sendo por ela considerados três tipos básicos de edificações: aquelas de dois pavimentos em meia encosta, as de dois pavimentos implantadas no topo de uma elevação e a térrea pousada em meia encosta. A casa era pensada sempre para receber hospedes, possuindo cômodos mais reservados e outros mais afastados da intimidade da casa. "Logo após a varanda, a sala é o primeiro ambiente quando se entra" (NOVAIS, 2009 , p.27). Após a sala encontram-se os dormitórios e provavelmente, as alcovas que se voltavam para ela. A cozinha é localizada ao fundo da casa e tem a dispensa contígua a ela, sendo também a varanda e o alpendre elementos comuns nessas construções. 
As casas eram construídas com material do próprio local, predominando o uso da terra, pedra e madeira. Normalmente, não havia preocupação em fazer desaterro, corrigindo-se o desnível com maior altura do alicerce. Este tipo de solução deu à casa mineira um aspecto assobradado em um dos lados, e térreo do outro. Se houvesse suficiente, esta base era usada como porão, que normalmente era utilizado como depósito ou cômodo para os escravos. Mesmo se a casa não possuísse porão ela era sempre mais elevada em relação ao terreno natural (NOVAIS, 2009, p.2930).

Era comum nas casas o alpendre frontal com escadas em madeira, ou em pedra. Contudo, cabe lembrar que devido à derrubada da mata atlântica, nas propriedades rurais, o uso de elementos de madeira no complexo edificado era amplo. Sua aplicação em edificações é bastante antiga, sendo que o seu emprego em estruturas e componentes diversos das construções, tais como paredes, vedações, revestimentos, forros, pisos é muito comum. Cruz (2008) ressalta que em Minas, o sistema construtivo tradicional é composto majoritariamente por estruturas em gaiola de madeira e vedação em adobe, pau-a-pique ou taipa de pilão, menos utilizada. Argamassa de barro, areia e cal e pintura simples em cal. Os telhados são em madeira e a cobertura, em telhas de barro do tipo capa e canal.As pesquisas de Novais (2009) se voltam para um exemplar da arquitetura rural em Rio Casca, MG, e para as questões das reflexões aqui desenvolvidas, cabe destacar que conforme Gonçalves (2008), Manoel Esteves de Lima também possuía propriedades em Rio Casca, MG. Novais (2009) evidencia que o núcleo original da Casa Sede da Fazenda da Cachoeira em Rio Casa, MG, do século XVIII, possui partido arquitetônico de casa assobradada e alpendre. Para ela, a maioria das edificações mineiras possui conformação, onde os diversos cômodos se voltam para um maior que acolhe e centraliza a organização da casa.

Essa característica construtiva é frequente nos exemplares relacionados no sul do Espírito Santo, na região entre os vales dos rios Itapemirim e Itabapoana. A partir de meados do século XIX a cultura cafeeira trouxe influências variadas para a região. Foram analisadas diversas fazendas dispersas por onze municípios (Figura 10). Constatou-se que as fazendas foram edificadas majoritariamente a partir da segunda metade do século XIX, e apresentam características comuns entre si e com 
a arquitetura mineira do século XVIII em sua maioria. Entretanto cada uma delas possui particularidades próprias, conforme é possível observar nas figuras 14 a 21 .

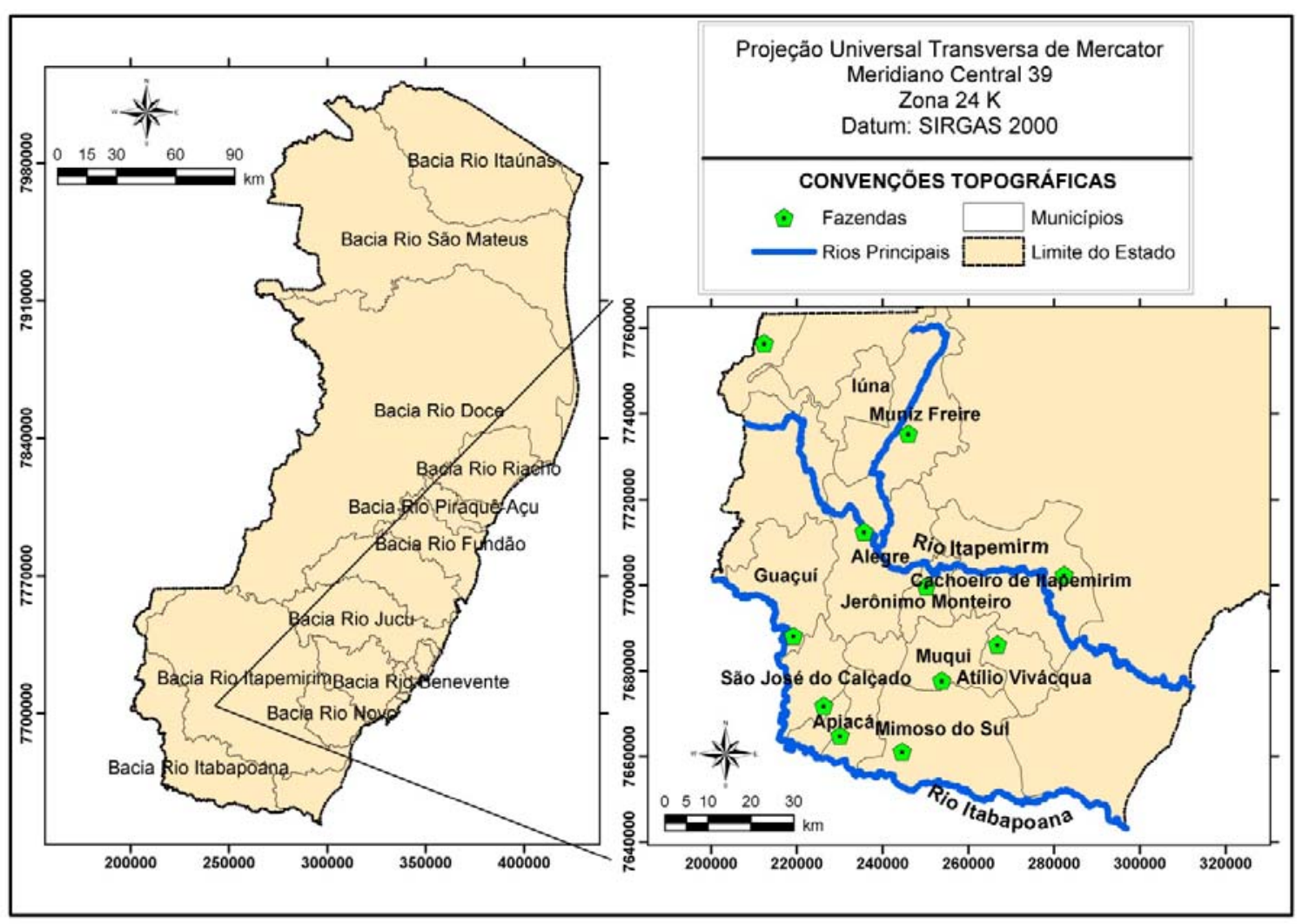

Figura 10. Municípios pertencentes à bacia hidrográfica do rio Itapemirim e do rio Itabapoana.

Tais sedes de fazendas encontram-se no tradicional trecho de conexão entre Minas Gerais e o Porto de Itapemirim do século XIX, e área de influência entre Espírito Santo e norte do Rio de Janeiro. Esses caminhos desempenharam importante papel para a integração econômica, política e social no interior capixaba durante o século XIX. Observou-se ainda que na região dessas fazendas, o sistema de distribuição de terras era por sesmarias, como o caso da fazenda eleita para detalhamento das reflexões aqui desenvolvidas, a Fazenda Fortaleza, localizada em Alegre, ES. A figura 11 traz a conexão viária atual da Fortaleza com a região sul, contribuindo para a noção de conectividade entre as fazendas visitadas, representadas no Apêndice $A$, além de mostrar a proximidade desta fazenda com a provável estrada de João do Monte da Fonseca, do século XIX, atual BR 482, e sua adjacência ao rio Braço Norte Esquerdo formador do rio Itapemirim. 


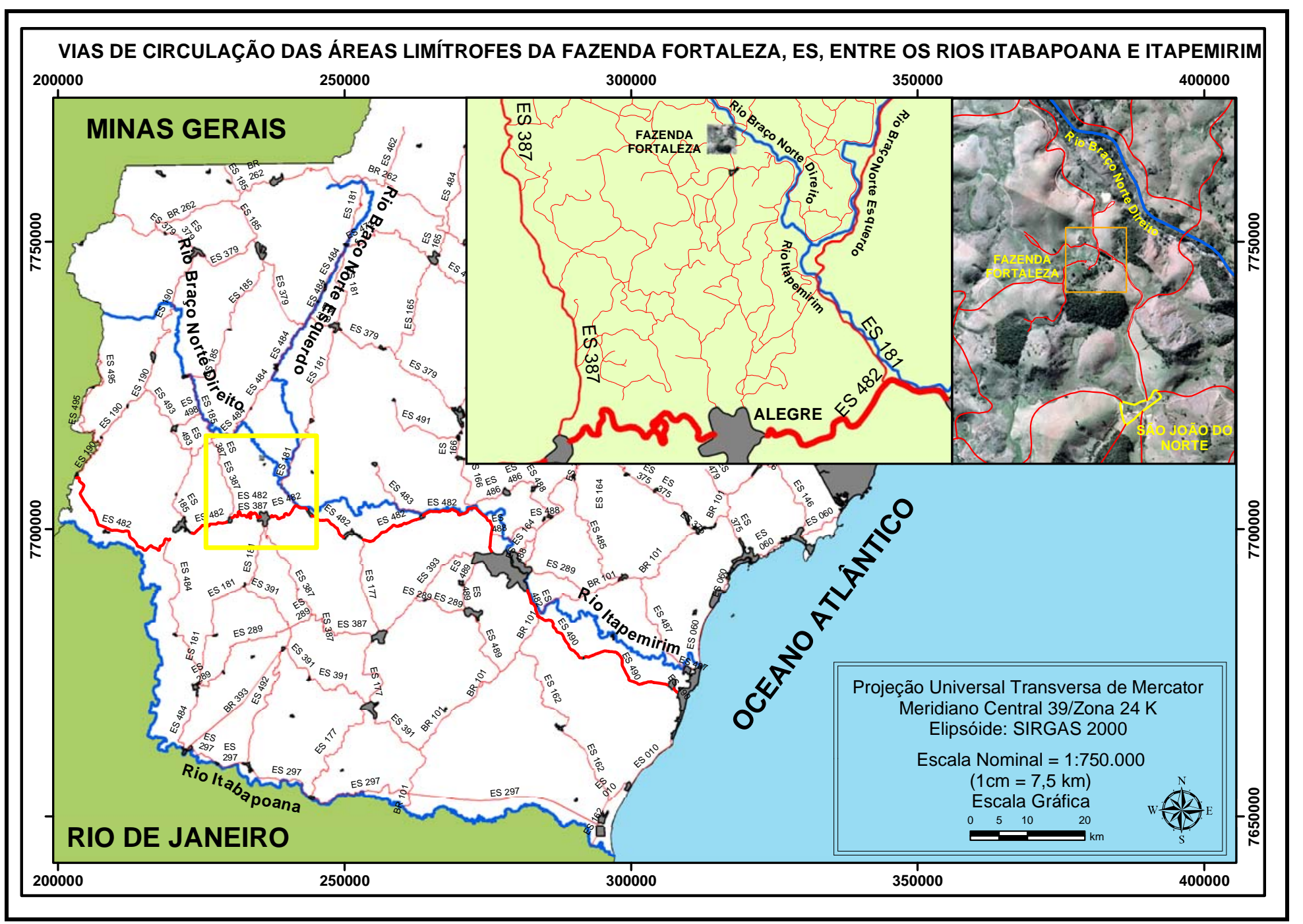

Figura 11. Caminhos de conectividade entre os rios Itabapoana Itapemirim. Destaque para proximidades da fazenda Fortaleza, Alegre, ES. 
O conceito de bem cultural passa por entendimentos atrelados a uma dimensão quantitativa, com necessária tutela, adequado empenho e defesa da documentação histórico-testemunhal, percebendo-o como "testemunho dos valores de uma civilização, expressão de uma cultura material, "objetos de pesquisa científica" (CARBONARA, 2005).

De acordo com a Carta de Veneza (1964), acredita-se que os critérios de conservação e preservação se transformam e devem ser continuamente debatidos dentro dos conceitos de cada época. Convém ainda destacar que diante do patrimônio rural, relaciona-se com instrumentos de suportes materiais que representem a memória da coletividade, e ao longo do tempo, ofereçam leituras novas e diferentes que possam contribuir em futuras adaptações à realidade rural daquele determinado contexto. É através da conservação que se pode garantir o direito de acessar o conhecimento que estes bens culturais trazem consigo. Assim, ações ou projetos de suporte à identificação, reconhecimento, conservação e gestão, objetivando a preservação material ou proteção de bens culturais de forma a garantir sua permanência e usufruto à sociedade na atualidade e para o futuro, representa um exercício de cidadania.

Nesse sentido, iniciou-se o mapeamento de fazendas no sul do estado do Espírito Santo, definindo-se a região de pesquisa em função das bacias hidrográficas dos rios Itapemirim e Itabapoana, e área de ocupação rural pioneira da cafeicultura. Foram excluídos os municípios e/ou propriedades de ocupação pioneira da cana de açúcar, reforçando assim os estudos em imóveis de meados do século XIX. Na expectativa de se obter uma amostragem do patrimônio rural do sul do estado, relacionaram-se exemplares em pontos diversos da região, não se atendo necessariamente à obtenção de registros de exemplares relevantes em maior número por localidade, conforme figuras 14 a 21 . Isso indica uma segunda etapa de mapeamento de bens culturais rurais relevantes por município, tendo, por exemplo, em Alegre, no distrito do Café, um conjunto significativo a ser inventariado.

Após se relacionar a amostragem para a região entre os vales dos rios Itabapoana e Itapemirim, efetivou-se o levantamento métrico simplificado e fotográfico das fazendas, com registro de dados básicos da realidade de cada unidade visitada em planilha do Excel, como consta na Figura 13. 
Do ponto de vista da implantação das sedes das fazendas, cabe destacar que na escolha do local para edificar a Casa Sede, a existência de água para o abastecimento próprio e outras finalidades representou fator preponderante, como já destaca Werneck (1878).

Após análise da posição da Casa Sede no terreno, constatou-se que a maioria situa-se em encosta, mostrando fachadas perpendiculares ao aclive do terreno. Com exceção de modificações recentes, percebe-se que não houve preocupação em realizar cortes e aterros na topografia natural. Ou seja, foram realizadas apenas correção do desnível com alicerces da construção, ficando o porão mais alto na parte frontal das casas, e fundos no nível da terra, atendendo a área de serviço.

De modo geral os porões foram subdivididos em, duas, três ou quatro partes e utilizados como depósito, abrigo de animais e conforme relatos, ainda funcionavam senzalas, como na fazenda Memória em São José do Calçado, ES. Em quase todas as sedes pesquisadas, são utilizadas pedras no preenchimento da alvenaria estrutural no porão, que trabalha conjugada com a estrutura em gaiola de madeira. As vedações de todas as sedes de fazenda são em madeira para os vãos e tijolos para as alvenarias, que representam substituição na maioria das situações ao pau-a-pique, ainda remanescente em algumas alvenarias internas (Figura 12).

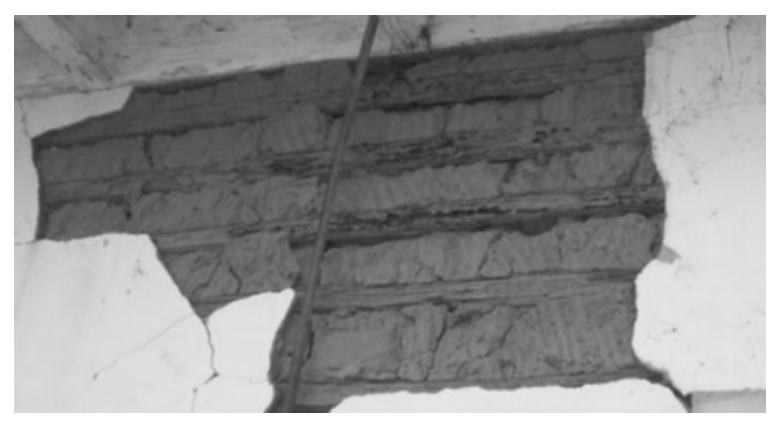

Figura 12. Alvenaria em pau-a-pique. Fazenda Fortaleza, Alegre (ES)

Foi verificado o assentamento posterior de guilhotina em janelas de algumas fazendas, mas a maioria mantém o enquadramento e vedação em tábuas de madeira colocadas em plano único com juntas secas, conforme especifica Vasconcellos (1979). Verificou-se ainda que foram fechadas posteriormente algumas varandas entaladas no corpo da edificação e os vidros utilizados nas janelas são pequenos em sua maioria, devido à dificuldade de transporte do litoral para interior no século XIX. 
A presença de alpendre ${ }^{4}$ projetado na frente da casa foi notada na maioria das sedes pesquisadas. Por consequência disso e da implantação em aclive, quase todas as casas possuem escada na fachada frontal. A solução de planta das sedes visitadas apresenta proporções quadráticas ou retangulares. Todavia, acredita-se que tenham passado por dois momentos de transformação, sendo originalmente plantas quadráticas, pois o bloco principal da construção é visível, e posteriormente, ampliadas para plantas retangulares. Além disso, outras fazendas passaram por adaptações mais recentes para ajustes aos modos atuais de moradia, como a Fazenda dos Andes em Muqui, que apresenta características de planta em "U". De todo modo, são encontradas plantas quadráticas em "L" e em "U", conforme figuras 14 a 21.

O número de cômodos variou muito em função de modificações internas, mas percebe-se um padrão em termos de distribuição espacial e organização das partes. Todas as sedes são elevadas em relação ao nível da terra, exceto a fazenda Palestina em Mimoso do Sul, talvez pela proximidade com o norte fluminense, que oferece outras influências arquitetônicas. Em geral, as edificações identificadas possuem solução de boa ventilação e insolação, construídas em tijolos e madeira e já tiveram o pau-a-pique como importante componente. Algumas mantêm atividades múltiplas de exploração da terra, sendo que a fazenda dos Andes em Muqui é a que possui o programa mais amplo, com o maior número de componentes para o ambiente construído, como engenho, chiqueiro e galinheiro. Com relação às funções complementares, não foi percebida a presença de capelas nas sedes visitadas, conforme figuras 14 a 21, apesar do conhecimento da presença de capelas em outras fazendas da região, como a Gironda em Jerônimo Monteiro.

Há, portanto, fortes indícios, percebidos por meio da observação apenas da arquitetura, de que os mineiros representam os pioneiros na ocupação do sul do Espírito Santo, independentemente dos manuscritos históricos.

\footnotetext{
${ }^{4}$ Cabe esclarecer que Vasconcelos (1979), pautado no sistema construtivo, apresenta como diferença entre varanda e alpendre, o fato de o alpendre ter telhado independente, enquanto na varanda, o telhado é a continuação do corpo principal da edificação. Lemos (1999), por sua vez, define alpendre e varanda em função do uso e distribuição espacial na edificação. Para as reflexões do estudo aqui desenvolvido entende-se que ambas as compreensões podem conviver e serem aceitas.
} 


\begin{tabular}{|c|c|c|c|c|c|c|c|c|c|c|c|c|c|c|c|c|c|c|c|c|c|c|c|c|c|c|c|c|c|c|c|c|c|c|c|c|c|}
\hline \multirow[b]{3}{*}{22 Denominaçăó da Propiededade } & \multicolumn{14}{|c|}{ 3. CARACIERZACĀO } & \multirow{2}{*}{\multicolumn{14}{|c|}{\begin{tabular}{|c|} 
4. TIPOLOGIA \\
41. Alpendre 4 42 Partido Arguit
\end{tabular}}} & \multirow{2}{*}{\multicolumn{8}{|c|}{ 5. ARQUIIIIURA }} & \multirow{3}{*}{ 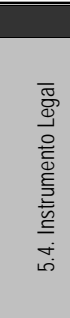 } \\
\hline & \multicolumn{5}{|c|}{ 3.1. Caracterização extemen } & \multirow[b]{2}{*}{3.2 Casa sede } & \multicolumn{5}{|c|}{ 3.3. Tecrica Construtiva } & \multicolumn{3}{|c|}{ 3.4. Implantacao } & & & & & & & & & & & & & & & & & & & & & & & \\
\hline & & & & & $\begin{array}{l}\text { 离 } \\
\end{array}$ & & 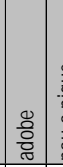 & & & 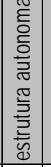 & 孚 & & 兽 & 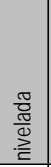 & & & & 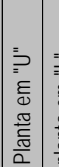 & 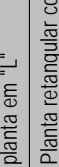 & 을 & & & & & & & & 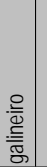 & 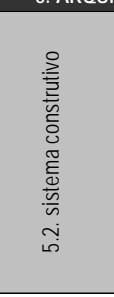 & \multicolumn{3}{|c|}{ ○. } & \multicolumn{2}{|c|}{ 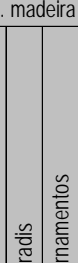 } & & 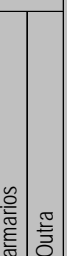 & \\
\hline Cava Roxa & & & 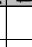 & $\mathrm{x}$ & $x$ & & & t. & $\mathrm{x}$ & & & $\mathrm{x}$ & & + & & to & & 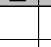 & $\mathrm{x}$ & & $\mathrm{x}$ & 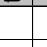 & 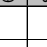 & $x$ & (t) & $\mathrm{x}$ & 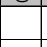 & 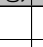 & & $\mathrm{x}$ & $-x$ & 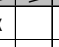 & $\mathrm{x}$ & 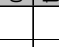 & & & \\
\hline Fazenda Batatal & & & 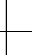 & $x$ & $x$ & & & & $x$ & $x$ & & $x$ & & 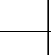 & & & & & & $x$ & & & & $x \times x$ & $x$ & & 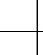 & 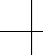 & & \begin{tabular}{|l|l|l|l|}
$x$ & $x$
\end{tabular} & $x_{x}$ & $x$ & $t_{1}$ & & 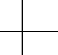 & & \\
\hline & & & & & & & & & & & & & & & & & & 1 & 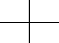 & & & & & & & & $\mathrm{C}$ & 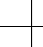 & & $\begin{array}{ll}x & x \\
x & y\end{array}$ & |x & $|x|$ & & & 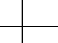 & & \\
\hline Fazenda da Ponte & & & $\mathrm{x}$ & & $\mathrm{x}$ & & & & $\mathrm{x}$ & $x$ & & $x$ & & & & & & 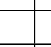 & $\mathrm{x}$ & & $\mathrm{x}$ & & & $x$ & $x$ & & 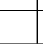 & 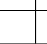 & & \begin{tabular}{l|l}
$x$ & $x$ \\
$x$
\end{tabular} & \begin{tabular}{l|l}
$x$ & $x$ \\
\end{tabular} & $x \mid$ & & & $\mathrm{x}$ & & \\
\hline Fazenda dos Antes $(96 \mathrm{hec})$ & & & $x$ & & $x$ & & & & $\mathrm{x}$ & $|x|$ & & $x$ & & 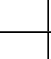 & & & & $\frac{1}{x}$ & t & & $x$ & & $\frac{1}{x}$ & \begin{tabular}{l|l}
$x$ \\
$x$ & $x$
\end{tabular} & \begin{tabular}{|l|l}
$x$ & $x$ \\
\end{tabular} & $\frac{1}{x}$ & $\mathrm{x}$ & $\frac{1}{x}$ & & \begin{tabular}{l|l} 
& \\
$x$ & $x$
\end{tabular} & \begin{tabular}{l|l}
$x$ \\
$x$
\end{tabular} & $x$ & & & $x$ & & \\
\hline & & & & & & & & & & & & & & & & & & & & & & & & & & & & & & 1 & & 1 & & & & & \\
\hline Fazenda Memoria & & & & $\mathrm{x}$ & $x$ & & & & & $x$ & & $x$ & & & & & & & $x$ & & 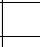 & & & \begin{tabular}{l|l}
$x$ & $x$ \\
\end{tabular} & $x$ & $x$ & & & & \begin{tabular}{l|l}
$x$ & $x$ \\
$x$
\end{tabular} & \begin{tabular}{l|l}
$x$ & $x$ \\
\end{tabular} & $x$ & & & E & & \\
\hline Fazenda Surridouro & & $x \times$ & & $x$ & $\times$ & & & & & 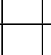 & & - & & $x$ & & & & 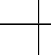 & $x$ & & 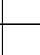 & & & $x$ & 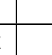 & 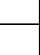 & & & & \begin{tabular}{l|l}
$x$ & \\
$x$ & $y$
\end{tabular} & $x+x$ & k & $\mathrm{x}$ & $\times$ & $x$ & & \\
\hline & & & & & & & & & & & & & & & & & & & & & - & & & & & & & & & & & & & & & & \\
\hline & & & & & $x$ & & & $x$ & & $x$ & & $x$ & & & & & & & $x$ & & 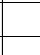 & & & $x$ & 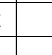 & & & & & $\begin{array}{l}x \times \\
x\end{array}$ & \begin{tabular}{c|c}
$x$ & $x$ \\
$x$
\end{tabular} & . & & & \begin{tabular}{l|l}
$x$ \\
\end{tabular} & & \\
\hline Fazenda Palestina & & & & & $\mathrm{x}$ & & & & $\mathrm{x}$ & & & & & $\mathrm{x}$ & & & & & $x$ & it & $\mathrm{x}$ & & & $x$ & ( & & & & & \begin{tabular}{c|c}
$x$ & $x$ \\
\end{tabular} & $\mathrm{x}$ & & & & 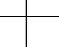 & & \\
\hline & & & & & & & & & & & & & & & & & & & & & 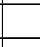 & & & & & & & & & - & & & & & & & \\
\hline Fazenda Confluênnia & $x$ & $x$ & & & $x$ & & & & & & & & & $x$ & & & & & $x$ & & 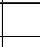 & & & & T & $x$ & & & & \begin{tabular}{l|l}
$x$ & $x$ \\
$x$
\end{tabular} & \begin{tabular}{l|l}
$x$ & $x$ \\
\end{tabular} & $x$ & & & $x$ & & \\
\hline & & & & & & & & & & & & & & & & & & & & & & & & & & & & & & & & & & & & & \\
\hline Fazenda Belo Jardim & & & $x$ & & $x$ & & & & & & & & & $x$ & & & & & $x$ & & $x$ & & & $x$ & 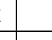 & $x$ & & & & $\mathrm{x}$ & $x$ & $\mathrm{x}$ & & $\mathrm{x}$ & $x$ & & \\
\hline & & & & & & & & & & & & & & & & & & & & & & & & & & & & & & & & & & & & & \\
\hline
\end{tabular}

Figura 13. Dados gerais das Fazendas visitadas no sul do Espírito Santo. 
Fazenda dos Andes, Muqui

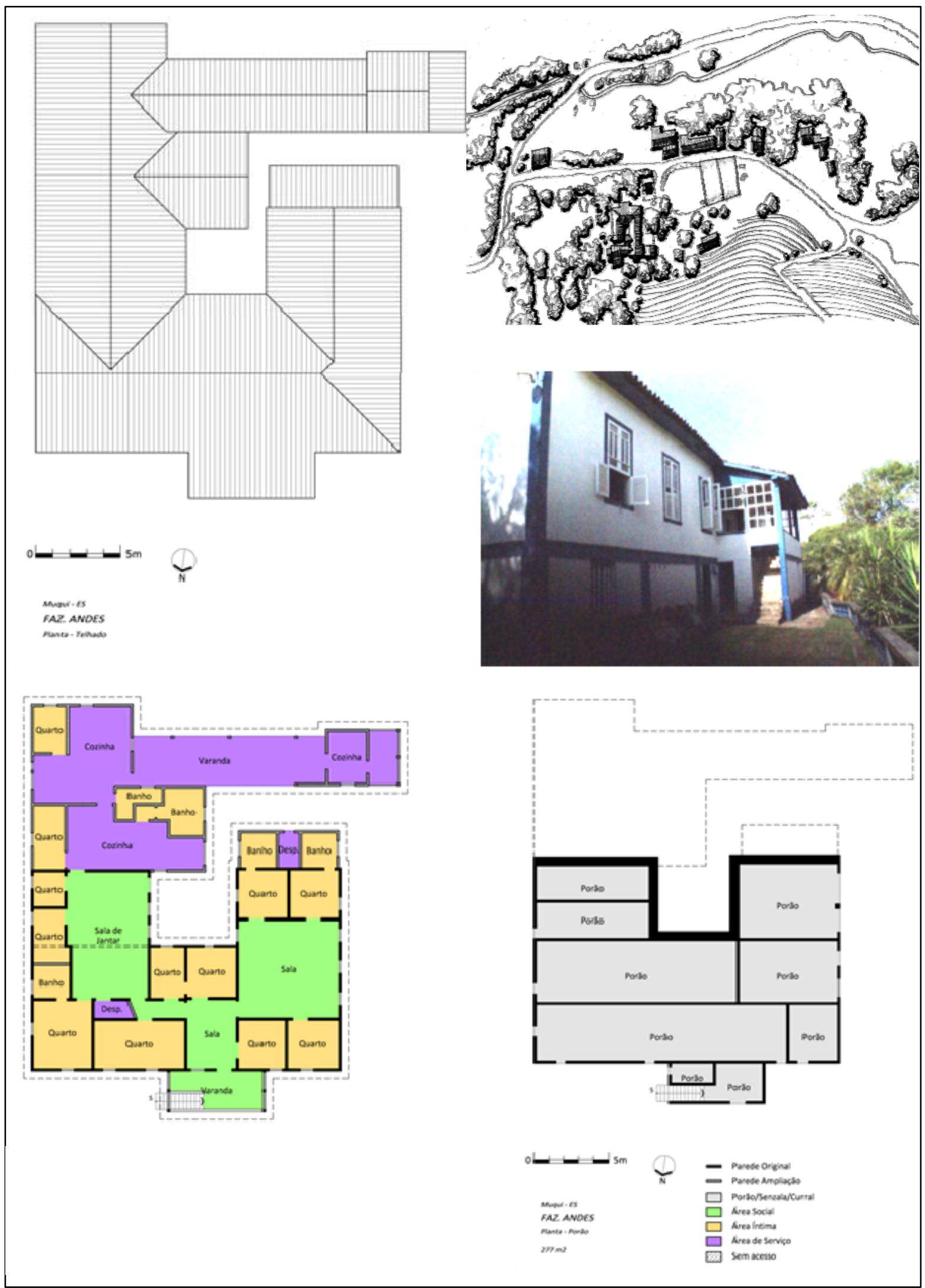

Figura 14. Fazenda dos Andes, Muqui (ES). Desenho Mateus Rosada, 2012. 
Fazenda da Ponte, luna

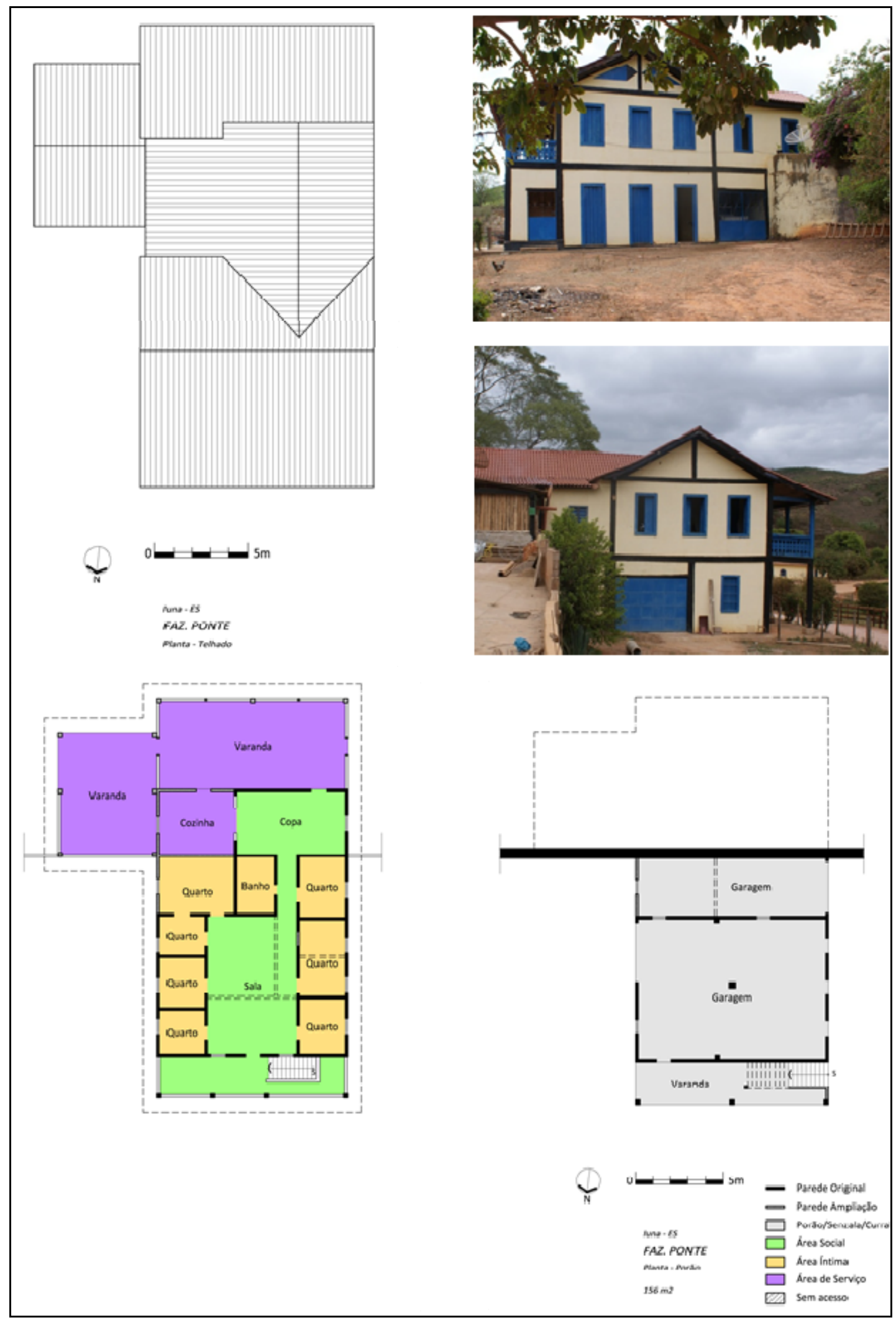

Figura15. Fazenda da Ponte, luna (ES). Desenho Mateus Rosada, 2012. 
Fazenda Batatal - Assentamento Teixeirinha - Apiacá

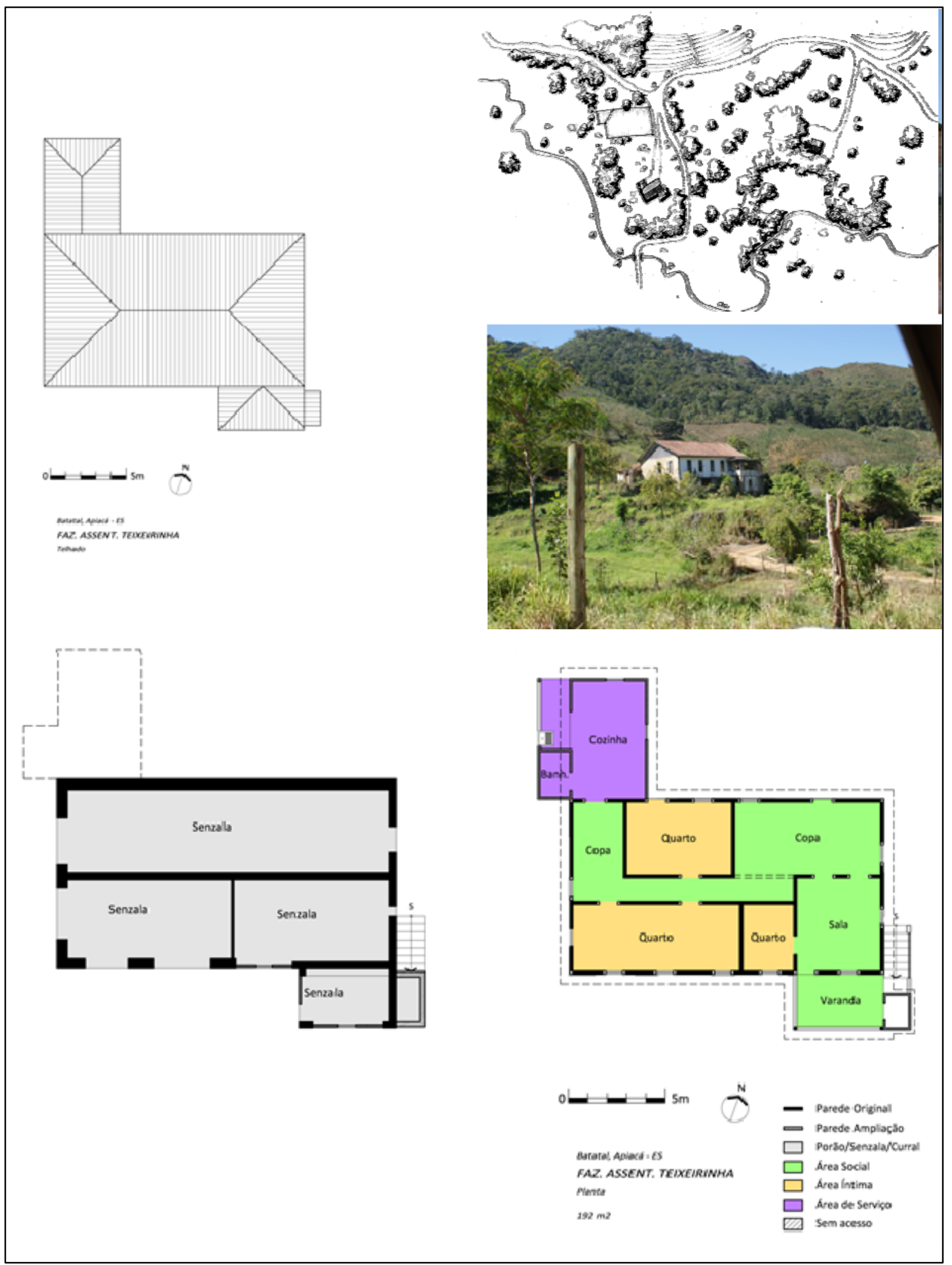

Figura 16. Fazenda Batatal, Apiacá (ES). Desenho Mateus Rosada, 2012. 
Fazenda Belo Monte, Bom Jesus do Norte (ES)

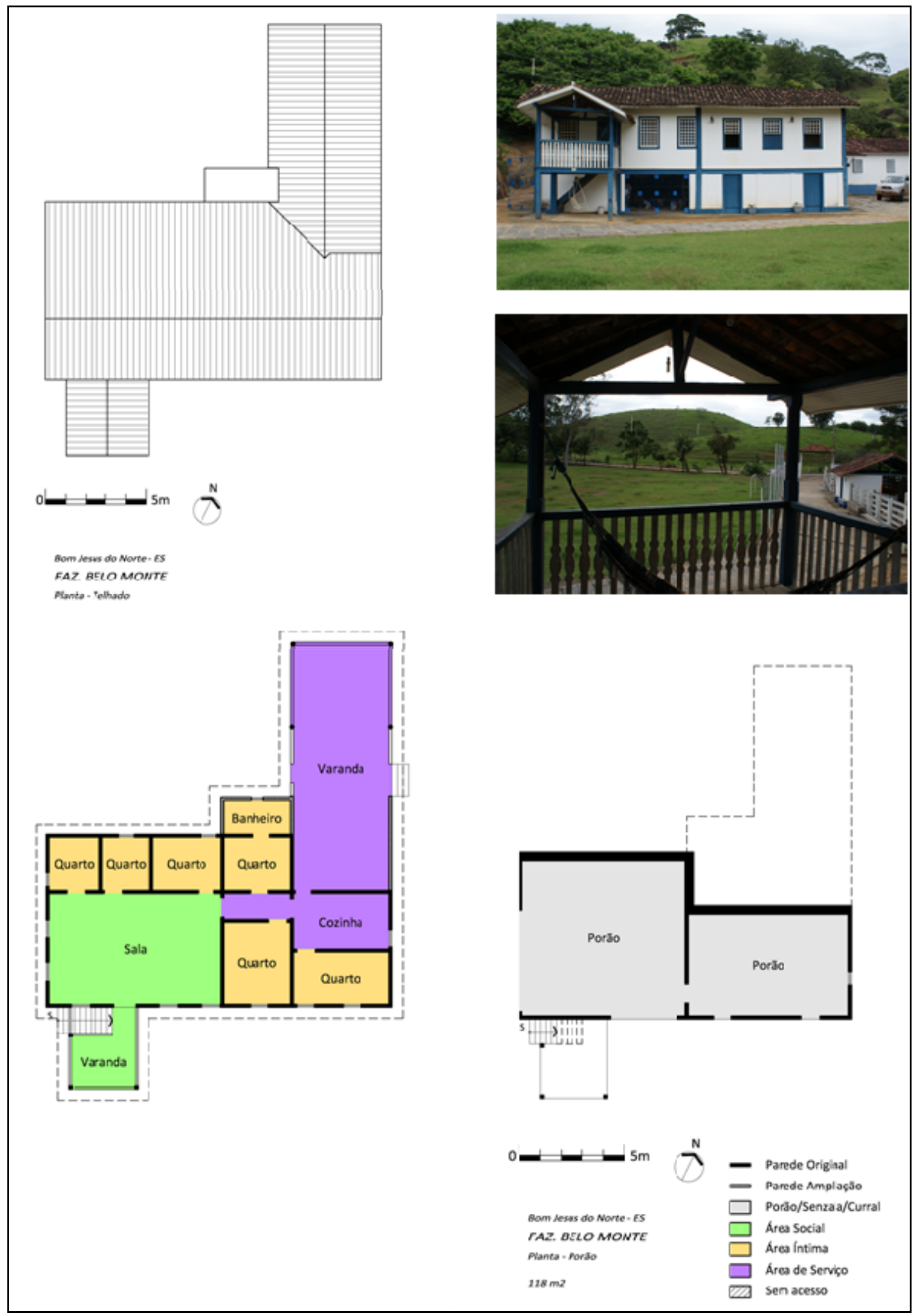

Figura 17. Fazenda Belo Monte, Bom Jesus do Norte (ES). Desenho Mateus Rosada, 2012. 
Fazenda Confluência, Divino de São Lourenço (ES)

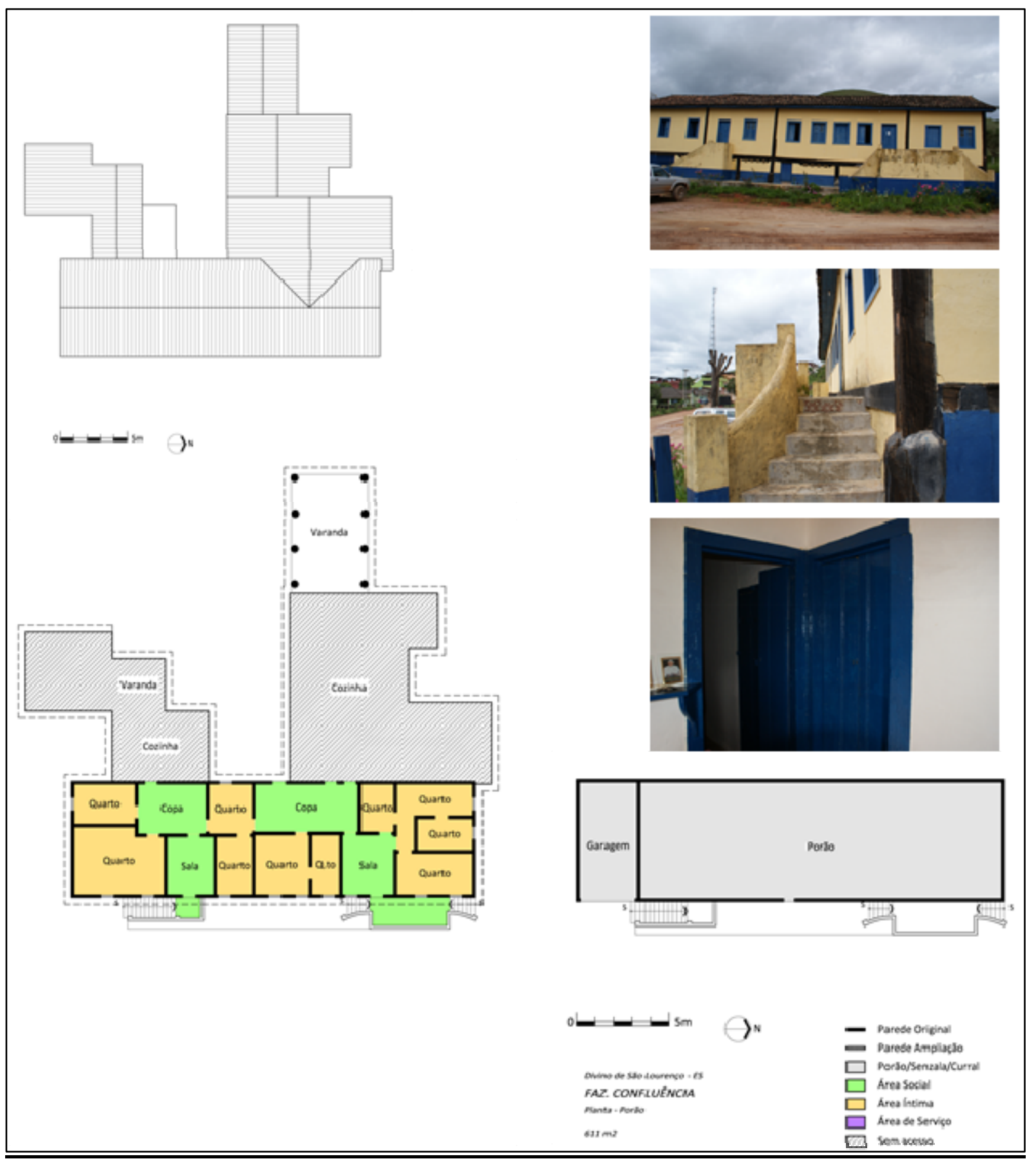

Figura 18. Fazenda Confluência, Divino de São Lourenço (ES). Desenho Mateus Rosada, 2012. 
Fazenda Memória, São José do Calçado (ES)

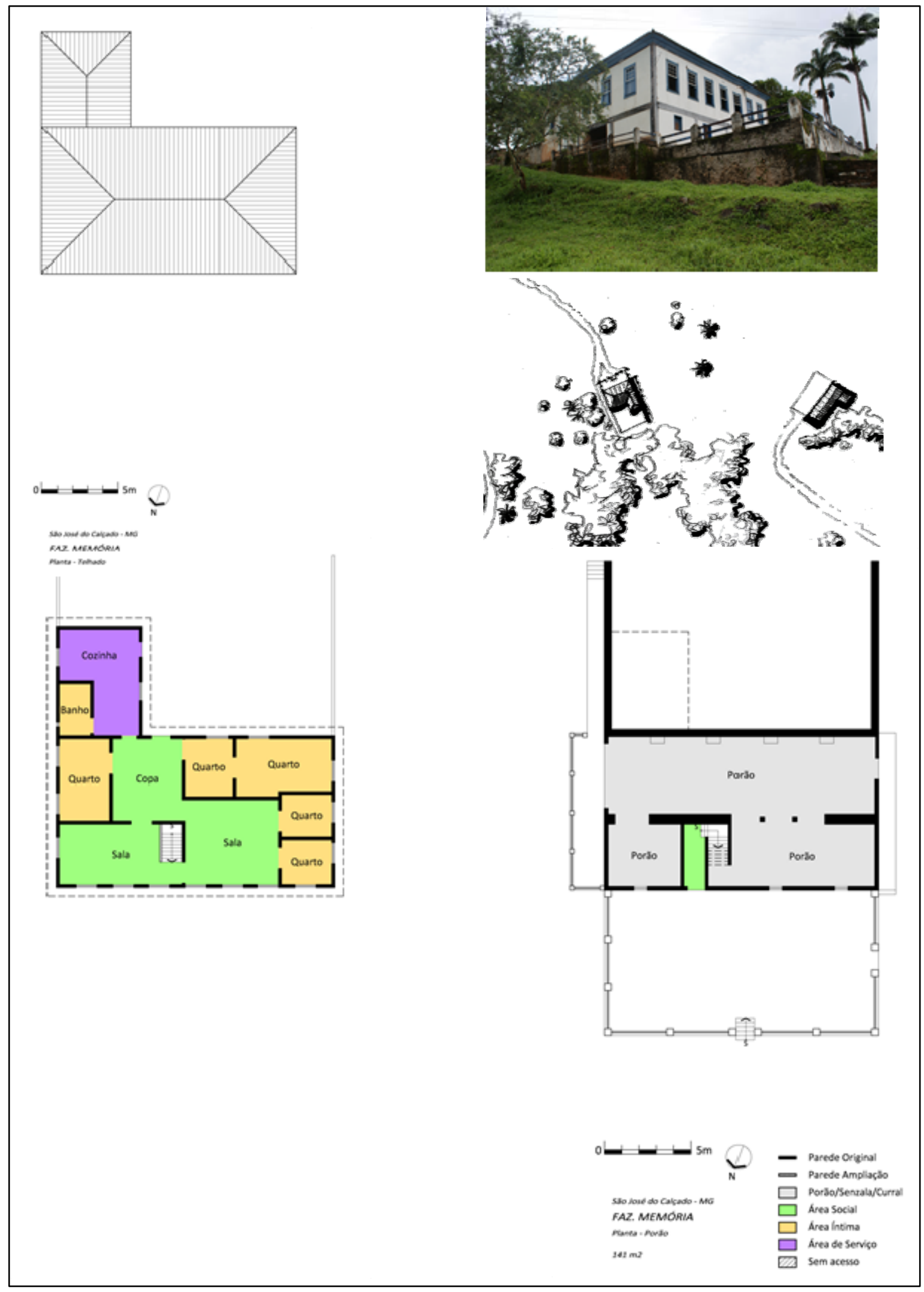

Figura 19. Fazenda Memória, São José do Calçado (ES). Desenho Mateus Rosada, 2012. 
Fazenda Palestina, Mimoso do Sul (ES)

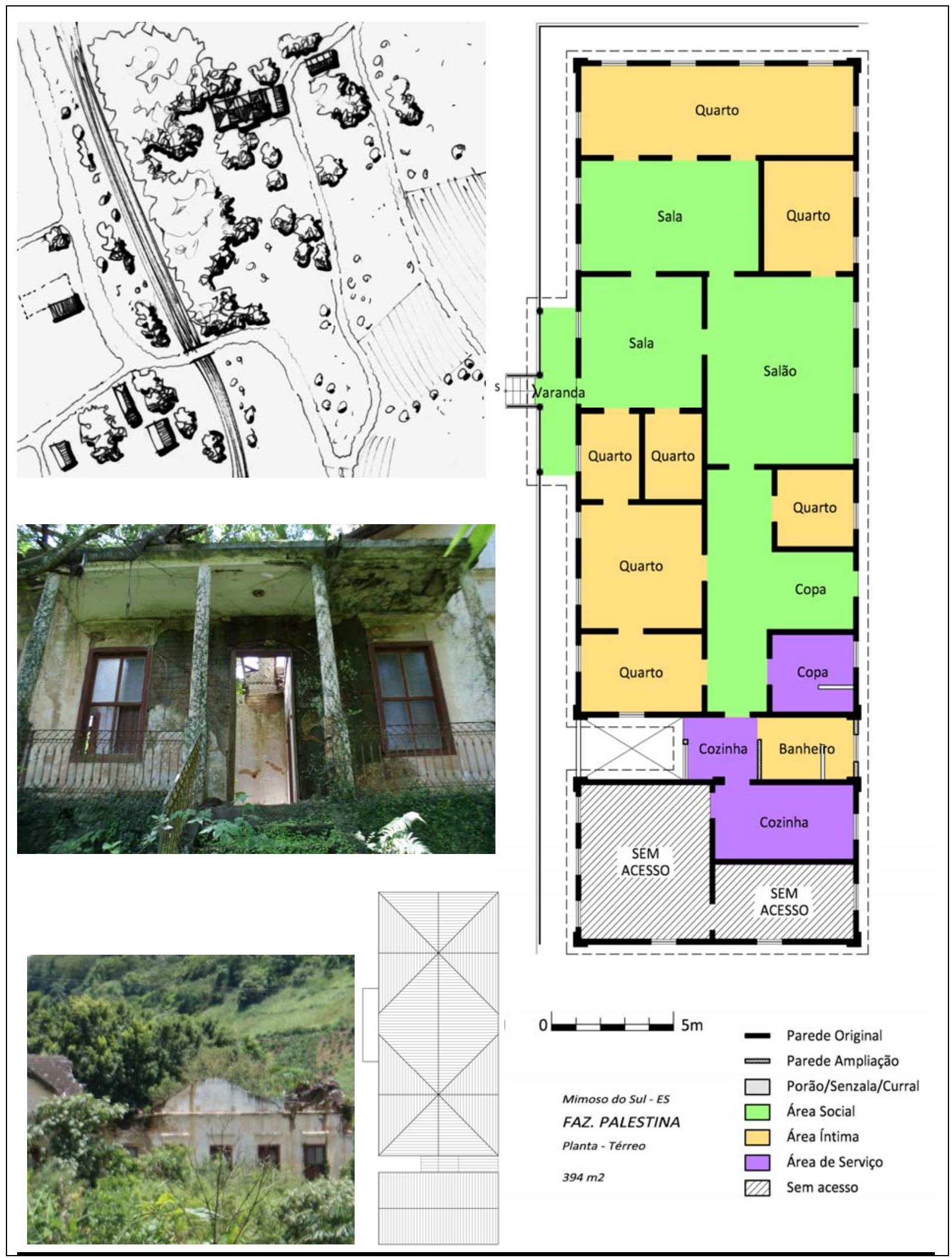

Figura 20. Fazenda Palestina, Mimoso do Sul (ES). Desenho Mateus Rosada, 2012. 
Fazenda Sumidouro, Atílio Vivácqua (ES)

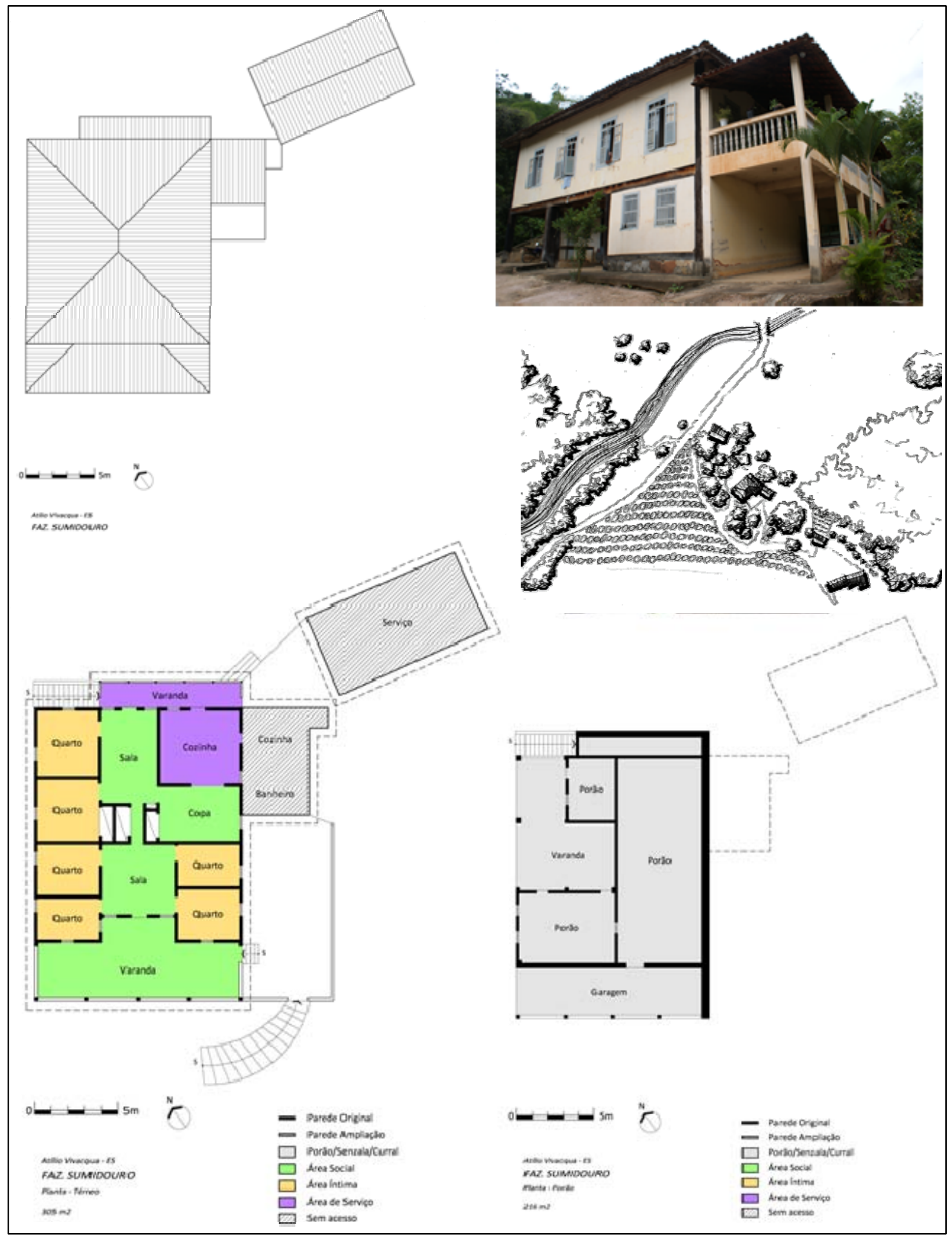

Figura 21. Fazenda Sumidouro, Atílio Vivácqua (ES). Desenho Mateus Rosada, 2012. 


\title{
1.3. A fazenda Fortaleza
}

Por acreditar que o conhecimento do universo rural diante das questões patrimoniais é fundamental para a manutenção da identidade nacional, considera-se que a utilização de ferramentas e técnicas adequadas à preservação dos bens culturais rurais é essencial. $\mathrm{Na}$ expectativa de analisar as condições atuais de uma fazenda de café fundada em meados do século XIX, enquanto patrimônio cultural do ambiente rural do Espírito Santo, tendo em vista o universo de pesquisa situado entre os rios Itabapoana e Itapemirim, elegeu-se a fazenda Fortaleza, município de Alegre, ES, para estudo das condições ambientais, conforme manuais de agricultura do século XIX. De acordo com Carrilho (2006, p.72), mesmo que haja variações tipológicas de implantação das fazendas oitocentista,

\begin{abstract}
há dois tipos fundamentais de arranjos do conjunto das instalações. O primeiro deles adota um esquema muito regular, constituído de um quadro bem alinhado, em que a distribuição das partes é perfeitamente ordenada. [...].

No segundo, como resultado de terrenos mais difíceis, a residência principal comparece deslocada em relação ao eixo principal da composição. Assimetria, aqui, não significa de modo nenhum desequilíbrio do conjunto, cuja harmonia é resolvida pelo jogo alternado entre as massas. Valendo-se muitas vezes de uma sucessão de planos, que vão se acomodando ao terreno, estes conjuntos oferecem um jogo de massas muito rico e variado. $\mathrm{O}$ exemplar mais conhecido é o da fazenda Pau d'Alho, em São José do Barreiro. Implantada à meia-encosta, suas edificações estão distribuídas em sucessivos patamares (CARRILHO, 2006, p.72).
\end{abstract}

Acredita-se que a fazenda Fortaleza localizada no município de Alegre, ES, seja um exemplar deste segundo modelo de implantação, descrito por Carrilho (2006), onde os volumes originalmente se distribuíam em patamares, tendo a Casa Sede implantada em meia encosta (Figura 22). A ocupação da região capixaba, onde se encontra atualmente o município de Alegre, teve início no século XIX, quando João do Monte da Fonseca, em 1815, organizou uma expedição que saiu da freguesia de Arrepiados, MG, rumo aos portos marítimos da então capitania do Espírito Santo, onde hoje podemos encontrar o estado do Espírito Santo e parte do 
estado de Minas Gerais. A expedição de João do Monte, além de abrir caminho em direção ao mar, pretendia erradicar a presença de índios Botocudos na região, e ainda investigar a ocorrência de ouro e prata nas serras e cascalhos dos rios que encontrasse pelo caminho (OLIVEIRA, 2009).

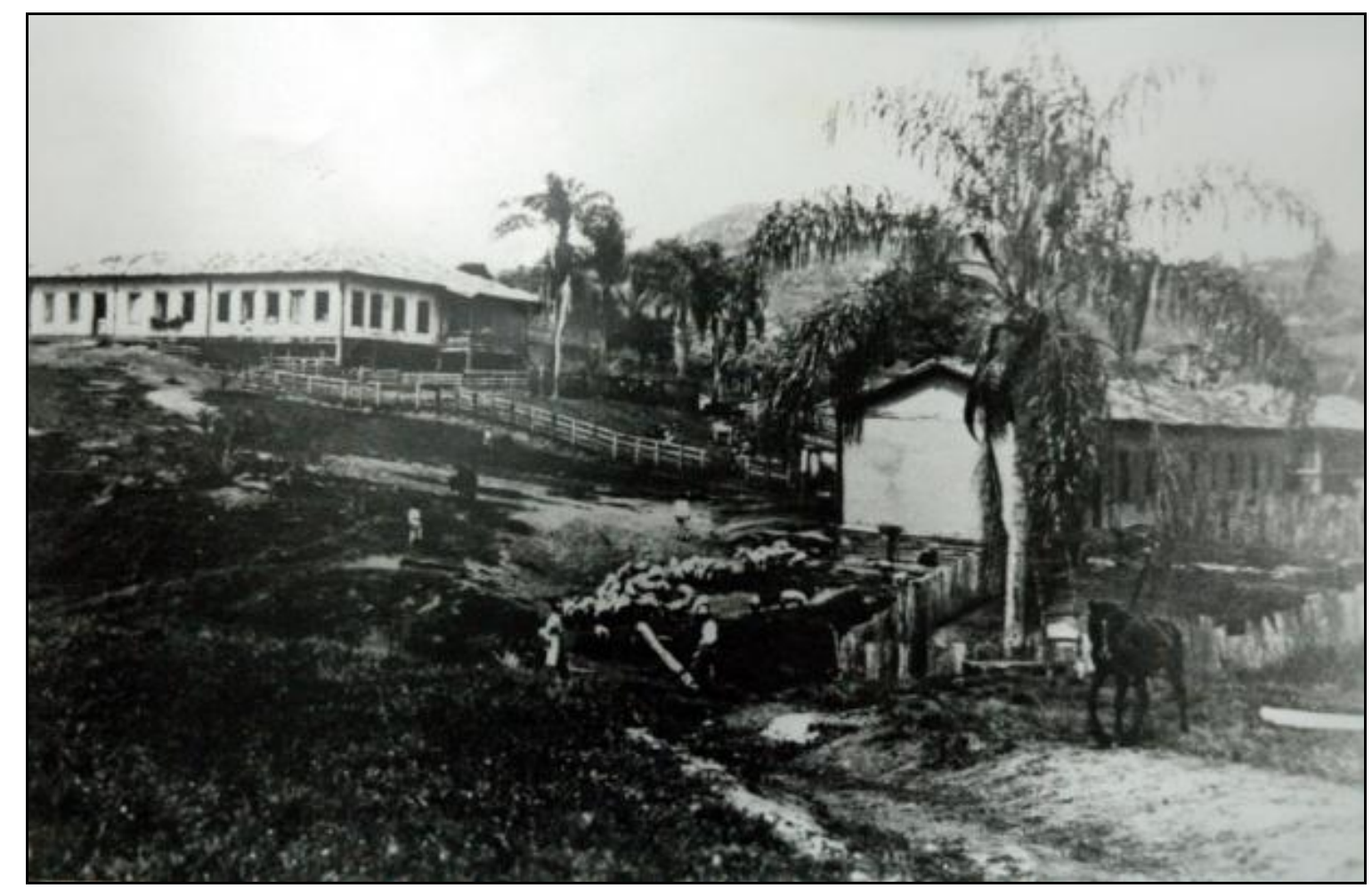

Figura 22. A Fazenda Fortaleza no ano de 1924, IGHA (2010).

Segundo Bravo (1998), próximo aos anos de 1820, Manoel Esteves de Lima, português, vindo de Minas Gerais à procura de terras férteis para a exploração agrícola, chegou onde hoje é a cidade de Alegre, passando pelo caminho que João do Monte da Fonseca abriu em 1815. Em seu retorno a Minas Gerais, Manuel Esteves entregou aos homens de sua bandeira, terras que formaram fazendas. De acordo com o Processo de Terras da Fazenda Fortaleza, na década de 1830, Euzébio Cabral da Fonseca colonizou áreas junto ao Córrego da Saudade, lugar este denominado na época Córrego do Pacheco. Em 1842, Euzébio transferiu "umas terras de agricultura e todas as mais vertentes e logradouros em lugar denominado Pacheco", na freguesia de Itapemirim, ao Coronel Francisco Xavier Monteiro Nogueira da Gama por novecentos e quarenta mil reis (INSTITUTO DE DEFESA AGROPECUÁRIA E FLORESTAL DO ESPÍRITO SANTO, 1924).

O Coronel Monteiro Nogueira da Gama nascera em Minas Gerais em 24 de abril de 1823, no arraial de Paulo Moreira (ALMADA, 1984, p.96). Ele se tornou 
proprietário de inúmeras fazendas no Espírito Santo, tais como a fazenda São Francisco, Sítio Mimoso, Cachoeira Coberta, Perdição, São João. De acordo com Bravo (1998), ele ao todo possuía propriedades referentes a 21 sesmarias, sendo o maior proprietário de terras da região. Além disso, contava com mais de 120 (cento e vinte) escravos, que trabalhavam preferencialmente nas fazendas Saudade e Fortaleza, e os demais nas outras propriedades das quais o coronel tinha posse (OLIVEIRA, 2009). A instalação da fazenda utilizava a derrubada da mata para o plantio, construção das edificações e conforme demonstra a planta e as medições de terras da fazenda Fortaleza constante dos processos de terras, registrado no ano de 1890 (INSTITUTO DE DEFESA AGROPECUÁRIA E FLORESTAL DO ESPÍRITO SANTO, 1924), as árvores eram utilizadas como marcadores de divisa de terras. Alguns registros dessas árvores que são encontrados no Processo de Terras da fazenda Fortaleza, são espécies como Angico, Guapeba, Angelim Amargoso, Graúna (Braúna Preta) e Peroba. Pioneiramente, a fazenda Fortaleza, que ainda era agregada à fazenda Saudade, possuía no total 267 (duzentos e sessenta e sete) alqueires ${ }^{5}$ de terra. A riqueza do solo recém exposto pelo desmatamento da mata atlântica permitiu a implantação de várias lavouras, como a de cafezais, roças de milho, canaviais e imensas pastagens para a criação de cabeças de gado, porcos de pasto e cabras. No Inventario de Matheus Monteiro da Gama, herdeiro direto do Coronel Francisco Xavier Monteiro da Gama, datado de 1890, registra-se que:

a fazenda Fortaleza consta de duzentos e sessenta e nove alqueires de terras, em comum com predita fazenda Saudade, com cafezais frutíferos, matas virgens, capoeiras e pastos, casa de sobrado para moradia, coberta de telhas com forro, engenho de pilões, engenho de cana e seus pertences, paiol, tulha, tenda de ferreiro e seus pertences, casa dos ex-escravos, moinho, bolandeira pra fazer farinha, ceva para porcos e casa pertencente à mesma, seis ranchos coberto de telha nas lavouras, cem cabeças de gado, vacaria, setenta cabeças de porco de pasto mais ou menos, vinte e cinco capados de ceva, ferramenta dos carpinteiros, um carretão, três carros com cangas, cambões, correntes e mais acessórios da lavoura pertencentes às ditas fazendas, mantimentos nas tulhas, mobílias constantes de dois sofás, mesa redonda com pedra mármore, duas marquesas, dez catres, quatro lavatórios, duas camas francesas, duas mesas grandes, duas ditas pequenas, caixa grande para guardar camas, dois armários, uma cômoda, um lavatório de pedra, um armário com medicamento, um armário para roupa, e outras duas mesas pequenas, seis tachas de cobre para assucar, fornos do mesmo metal, seis balanças, trem de cozinha,

\footnotetext{
${ }^{5}$ Conforme referência mineira, um alqueire equivale a 48.400 m2 (OLIVEIRA, 2009).
} 
louça, vidros, relógio de parede, talheres, relógio, e mais utensílios domésticos (INSTITUTO DE DEFESA AGROPECUÁRIA E FLORESTAL DO ESPÍRITO SANTO, 1924, p.37)

Observa-se que as descrições dos inventários não se detêm apenas ao interior da edificação, mas são amplas, contemplando o ambiente construído e o patrimônio exterior à edificação, como as matas, capoeiras, pastos e lavoura. A fazenda Fortaleza é um importante representante do período cafeeiro entre os vales dos rios Itabapoana e Itapemirim. De acordo com o Processo de Terras (INSTITUTO DE DEFESA AGROPECUÁRIA E FLORESTAL DO ESPÍRITO SANTO, 1924, p.8), em 1899 havia na propriedade:

duzentos e sessenta e sete alqueires de terras geométricas constituem as fazendas denominadas Fortaleza e Saudade, contendo mais ou menos 30 mil pés de café em estado regular e os demais abandonados, casas de morada e as demais existentes, com todos os acessórios e todas as benfeitorias.

E 1892, em escritura de compra e venda da fazenda Fortaleza é relatado conforme Processo de Terras, que em conjunto com a fazenda Saudade, consta de casa para moradia, casa de engenho com alambique, engenhoca de serra deteriorada, moinho e casa para tulhas, e

cafezais, canaviais, roças de milho, árvores frutíferas, matas virgens, capoeiras e pastos, casa de sobrado para moradia, coberta de telhas com forro, engenho de pilões, engenho de cana e seus pertences, casa dos escravos, bolandeira para fazer farinha, ceva para porcos e casa pertencente a elas, 6 ranchos cobertos de telha nas lavouras, oitenta cabeças de gado vacum, pequenos e grandes, 80 cabeças de porcos de pastos, 25 capados, 6 egoas e um jumento, 14 bestas de canga, mantimentos que houver em tulha e outros acessórios existentes (INSTITUTO DE DEFESA AGROPECUÁRIA E FLORESTAL DO ESPÍRITO SANTO, 1924, p.47)

O estudo do Processo de Terras da fazenda Fortaleza evidencia a importância que ela possui para a compreensão da configuração econômica e arquitetônica da região localizada entre os vales dos rios Itabapoana e Itapemirim, conforme os preceitos da época, respeitando os manuais de agricultura. Trata de exemplar com características da tradicional arquitetura mineira, importante para o período do café no Espírito Santo, datado da primeira metade do século XIX. 
2. PATRIMÔNIO RURAL: PROCEDIMENTOS PARA A SUA PRESERVAÇÃo 


\subsection{Manuais de agricultura do século XIX: ocupação do espaço e utilização da madeira}

Paisagens culturais são bens culturais e representam as obras "combinadas da natureza e do homem". Ilustram a evolução humana ao longo do tempo, sob a influência das restrições físicas e/ou oportunidades apresentadas pelo seu ambiente natural e dos condicionantes sociais, econômicos e culturais, tanto externos como interno a tais bens. Esse conceito surgiu no universo da geografia na década de 20 do século XX e foi efetivamente incorporado como instrumento legal de preservação em 1992 (UNESCO, 2003, p.19). Considera-se que paisagem organizada, é sinônimo de paisagem cultural, e é resultado de:

uma ação meditada, combinada e contínua do homem sobre o ambiente. Paisagens culturais podem ser ainda descritas como paisagens rurais, caracterizadas pelas atividades agro-pastoris ou urbana produto esta de aglomerações humanas (FILHO, 1998, p.10).

E de acordo com o geógrafo Filho (1998), a análise de uma paisagem, seja natural, modificada, ou cultural, exige o reconhecimento das diferentes escalas dos elementos de paisagem, que variam de tamanho, forma, tipo e heterogeneidade. Acredita-se que conhecer apenas a paisagem não seja suficiente para um adequado estudo das demandas culturais do ambiente rural, na busca pela preservação de seu patrimônio. Realizar pesquisa histórica, estudos das referências arquitetônicas e análise da forma e tamanho do ambiente construído e das áreas resultantes da ação do homem no meio ambiente, constitui instrumental adequado para melhor conhecer e gerir o universo cultural, vinculado ao patrimônio rural no sul do Espírito Santo.

Para Filho (1998), as simulações estocásticas espacialmente explícitas de uso da cobertura da terra em uma paisagem cultural ainda representam um desafio, apesar da diversidade de abordagens realizadas e atuais. Se a paisagem original dos morros foi alterada com a devastação da mata atlântica, as primeiras manifestações de construção de um universo paisagístico rural próprio e marcadamente brasileiro surgem neste contexto. Aparece uma nova paisagem, 
intimamente associada ao ambiente edificado, onde a presença da sede de uma fazenda à longa distância se avista.

Ha que se entender que esta transformação da paisagem não ocorreu de maneira puramente aleatória e empírica. No século XIX, surgiram inúmeros textos com o propósito de disponibilizar a partir de uma abordagem prática e objetiva, orientações sobre a forma adequada de implantação de uma fazenda com os mais diversos tipos de cultivos que poderiam ser de interesse do fazendeiro. Os "Manuais de Agricultura" no Brasil se consolidaram principalmente no momento de expansão da cultura de café no Vale do Paraíba. Esse tipo de literatura era usual e aborda as técnicas agrárias e o complexo industrial que caracteriza o ambiente rural daquele momento. Ao descrever o interior de uma fazenda, $\operatorname{Smith}^{6}(1941$, p.8) destaca que:

a sala de jantar é grande e de paredes lisas; de um lado há uma escrivaninha com alguns livros, notadamente manuais agrícolas, em português e francês [...]. Nem um livro sequer na sala; aliás, não existem outros na casa além dos manuais de agricultura.

Para Carrillho (2006), pesquisadores e estudiosos do ambiente rural como Luis Saia, Eduardo Silva, referenciam obras importantes, manuais, tais como o Tratado de Laborie e as Memórias do Barão de Paty de Alferes, contemplando fundamentalmente a discussão das técnicas agronômicas de maneira superficial, dificultando o entendimento das especificidades da organização do complexo rural cafeeiro. Neste sentido, Carrilho (2006) indica o exame dos próprios manuais para ampliar a compreensão dos preceitos adotados para a instalação de uma fazenda e sua agricultura.

Para as reflexões aqui desenvolvidas, optou-se então por buscar através das publicações de Laborie, em sua tradução de 1799 para o português, e das Memórias de Paty de Alferes, ampliada em sua terceira edição de 1878, adquirir compreensão dos parâmetros fundamentais para se construir uma fazenda, objetivando perceber o seu universo paisagístico e ambiental em prol da preservação do patrimônio rural capixaba na atualidade.

\footnotetext{
${ }^{6} \mathrm{SMITH}, \mathrm{H}$. H. Uma fazenda de café no tempo do Império. Rio de Janeiro: Departamento Nacional do Café, 1941, p. 8. In: CARRILHO, M.J. (2006)
} 
Laborie (1799, p.7) acredita que para se definir o local adequado ao cultivo de café deva-se contemplar a escolha de terras próximas aos cumes das montanhas, que por possuírem difícil acesso, devido ao emaranhado de matos que cobrem os declives das montanhas, podem ocasionar determinação de outras áreas para o cultivo em detrimento da investigação teórica indicada. Para ele, na mesma fazenda, variarão muito as terras, tanto na qualidade intrínseca do terreno, como na situação. As montanhas mais baixas e próximas às campinas são menos adequadas à produção do café, pois são quentes e de solo impróprio, em relação àquelas situadas nas partes altas, que são frias com terreno mais coeso, como os cafeeiros gostam. Tudo isso se reconhece a primeira vista.

As várias espécies de cedros, as outras árvores de lenho mole e branco, como também uma certa palmeira menor (chamada Chapelet) mostrarão evidentemente a bondade a frescura do terreno, em que crescem, mas sempre se requer alguma profundidade do terreno (LABORIE, 1799, p.11).

De todo modo, em seus escritos, Laborie (1799) esclarece que nos lugares baixos e quentes, as exposições solares ao norte e oeste são melhores, porque são mais frias. Já nos montes altos opta-se pela exposição solar a leste e sul, pois o calor é menor. Define ainda que para se instalar um estabelecimento rural de maneira adequada, há que se considerar prioritariamente, as seguintes conveniências como essenciais:

I. Que os caminhos, ou estradas, não sejam distantes.

II. Que seja vizinho de outras plantações, tanto por amor de suprimento de provisões de boca, e de plantas, que delas se pode tirar, como pela comunicação com criaturas racionais.

III. Que tenha água corrente.

IV. Que tenha madeiras, e arvores, ou plantas que dém colmo.

V. Que tenha pedras calcareas, e pedra para outros fins,

VI. Que haja algum lugar accessível, onde se possa effeituar o estabelecimento (LABORIE, 1799, p.15).

Percebe-se que os fatores ambientais e morfológicos são condicionantes básicos para se viver e cultivar terras. $\mathrm{O}$ autor ainda afirma que a fertilidade de terrenos em morros é de pouca duração, uma vez que as águas das chuvas lavam a superfície do solo e o degradam retirando-lhe os nutrientes e deixando a terra estéril. Para conservar os terrenos morrados, sugere a manutenção das raízes de árvores que ali estão entrelaçadas, que minimizam a degradação do solo (LABORIE, 1799, 
p.43). As orientações publicadas em manuais no século XIX contemplam ainda as importantes memórias do Barão Paty de Alferes. Para ele, quando um fazendeiro funda um estabelecimento rural, a primeira coisa a fazer é procurar água em abundância, e, encontrando-a, deve tirar o seu nível em direção à localidade mais vantajosa.

Entretanto, se a disposição do terreno não permitir essa escolha, sujeitar-se-á o lavrador às circunstâncias, e fundará a fazenda à feição da altura que a água alcançar em condições de constituir o mais possante motor. (WERNECK, 1878, p.1)

O autor considera ainda que as obras e construções rurais, apesar de importantes, não devem se isolar das plantações. Junto à residência deve reservar área favorável ao plantio de um pomar, que além de variedades de árvores frutíferas ou de embelezamento, possibilite laser ao agricultor e sua família. É necessário que o proprietário procure situar as habitações no lugar mais seco e enxuto do estabelecimento. Em localização de preferência próxima ao local da fazenda, devem ficar os pastos para os animais destinados ao serviço do pessoal e custeio do estabelecimento, como porcos para consumo, bois para os carros, vacarias para leite e carne, animais para movimento dos engenhos, mulas para carga, dentre outros.

Os caminhos constituem uma das mais importantes condições de uma boa fazenda. Quando traçados adequadamente em relação ao declive e a direção topográfica, facilitam os trabalhos e os serviços rurais, tornando práticos os transportes dos produtos e a locomoção das pessoas. É necessária, em um estabelecimento rural, uma estrada central que atravesse a fazenda, contemplando vários outros caminhos que se cruzam com essa estrada em inúmeros pontos, de maneira a permitir que o fazendeiro percorra a cavalo todas as plantações com entrada e saída distintas, entrando por um lado e saindo por outro (WERNECK, 1878).

O declive dos caminhos para carro ou bestas muares não deve exceder de 1 para 13; isto é, em cada 13 palmos deve haver um de subida. É evidente que, se puder ser de 1 para 14, 15 ou 16, melhor será o traço, e mais fácil o transporte e a locomoção. Os níveis empregados para a tirada das águas nos regos servem perfeitamente para essa demarcação, o modo de execução é 
idêntico, empregando-se também estacas de 1 palmo de altura. (WERNECK, 1878, p.8)

Os caminhos levam em consideração a largura adequada aos veículos em circulação na fazenda. Na margem destes, o autor aconselha plantar laranjeira e outras árvores frutíferas. Percebe-se que a compreensão das relações espaciais e morfológicas do ambiente natural e sua transformação pelo homem que o edificará e cultivará é fundamental para a determinação e apropriação adequada do espaço e da paisagem rural. Antes da instalação de uma fazenda, para se conhecer os terrenos férteis, as madeiras e sua qualidade para uso, Werneck (1878) esclarece que as terras são identificadas à distância por meio de suas florestas, principalmente na primavera, pois a florescência e cor das flores facilitam a classificação dos vegetais, assim como a folhagem das árvores, a configuração e altura dos galhos. Conhece-se pela madeira a qualidade das terras, se boa, media ou má. Nas terras boas encontra-se:

o superior óleo vermelho, o jacarandá-tan, o jacarandá roxo, o guarubu, a guararema, a guarapoca, a catinga de porco, a canela de sassafrás, o cedro, o jequitibá, a laranjeira, o arco de pipa, o pão parahyba, a canella de veado, o sucupira, o tinguassiba e outros. Nas terras médias achareis o guaraçahy, a peroba, a cabiúna, algum tipinhuan, a arucurana, a cangerana, o cataguá, a guarapiapunha, a canela do brejo, a canela preta, a canela cheirosa, a guarauna, o ipe, o taquara-ssú, a taquarapoca, e outros. Nas inferiores encontra-se muito tapinhuan, o ipê, o murici, o pão-caudo (pereira), o bacupary, o milho cozido, o negro-mina, muito caeté, a taquara de lixa, o cipó timbó, a serrapilheira e outras arvores e vegetais, que não existem em terra boa. (WERNECK, 1878, p.12)

Percebe-se que a localização do complexo edificado deve ser perto de boa água, os pastos e pomares devem ficar próximos da residência, os caminhos cruzarem toda a propriedade, a floresta ser identificada para avaliação da condição do solo e aproveitamento das madeiras. Ou seja, a Casa Sede, o ambiente construído, a água, os caminhos, os pastos e a floresta são essenciais na fundação de um estabelecimento rural, primordiais ao ambiente rural. Compreender as orientações dos principais manuais agrícolas, conforme Carrilho (2006), utilizados no século XIX, quando da fundação e aquisição de um estabelecimento rural, e considerar as demandas atuais de preservação destes imóveis entendidos como 
bens culturais, representam importante desafio para a permanência dos mesmos vistos em sua totalidade morfológica.

\subsection{A fenomenologia como leitura do patrimônio}

A fazenda Fortaleza é um importante exemplar oitocentista do patrimônio rural do sul do Espírito Santo. Ela está localizada em área de ocupação pioneira da região sul desse estado, e ainda possui boas condições de preservação, conforme ilustra a Figura 23. Ela é considerada um exemplar adequado para a realização dos estudos em geotecnologia para o patrimônio cultural no ambiente rural, pois não possui descaracterização ou alteração que comprometa sua unidade, mantendo assim a autenticidade do monumento, sustentando às ações do tempo e as intervenções posteriores à sua construção. Acredita-se que ela seja um objeto representativo que ilustra um conjunto de fazendas que podem ser encontradas no sul do Espírito Santo, conforme demonstram as figuras de número 14 a 21 . A fazenda Fortaleza possui ainda atributos básicos inerentes à implantação de um imóvel rural no século XIX, respeitando os tratados de agricultura que consideram corpos d'água, caminhos, floresta, área agriculturável, pastagens para animais e ambiente construído em sua concepção. Tais atributos podem ser encontrados em inúmeras fazendas de origem no século XIX, mas na Fortaleza, eles são expressivos e preservados, como mostram as figuras 15 e 16, com vegetação típica de toda a região, hidrografia e Casa Sede do período de fundação da fazenda.

Os estudos do ambiente rural que compõem o patrimônio cultural da fazenda Fortaleza, inclusive suas características topográficas, foram gerados considerando a definição da área de estudo recortada dentro do imóvel como um todo, a partir da delimitação de uma pequena região em um quadrante resultante do desenho de uma linha de 500 (quinhentos) metros em relação aos extremos dos beirais da Casa Sede da fazenda, conforme Figura 23 e Figura 24, área de estudo da fazenda 
Fortaleza. A distância de 500 metros é adotada, para exercício das análises aqui necessárias, por acreditar trazer a adequada escala de leitura que compõe o ambiente construído, possibilitando assim, a leitura da paisagem cultural do ambiente rural em estudo.

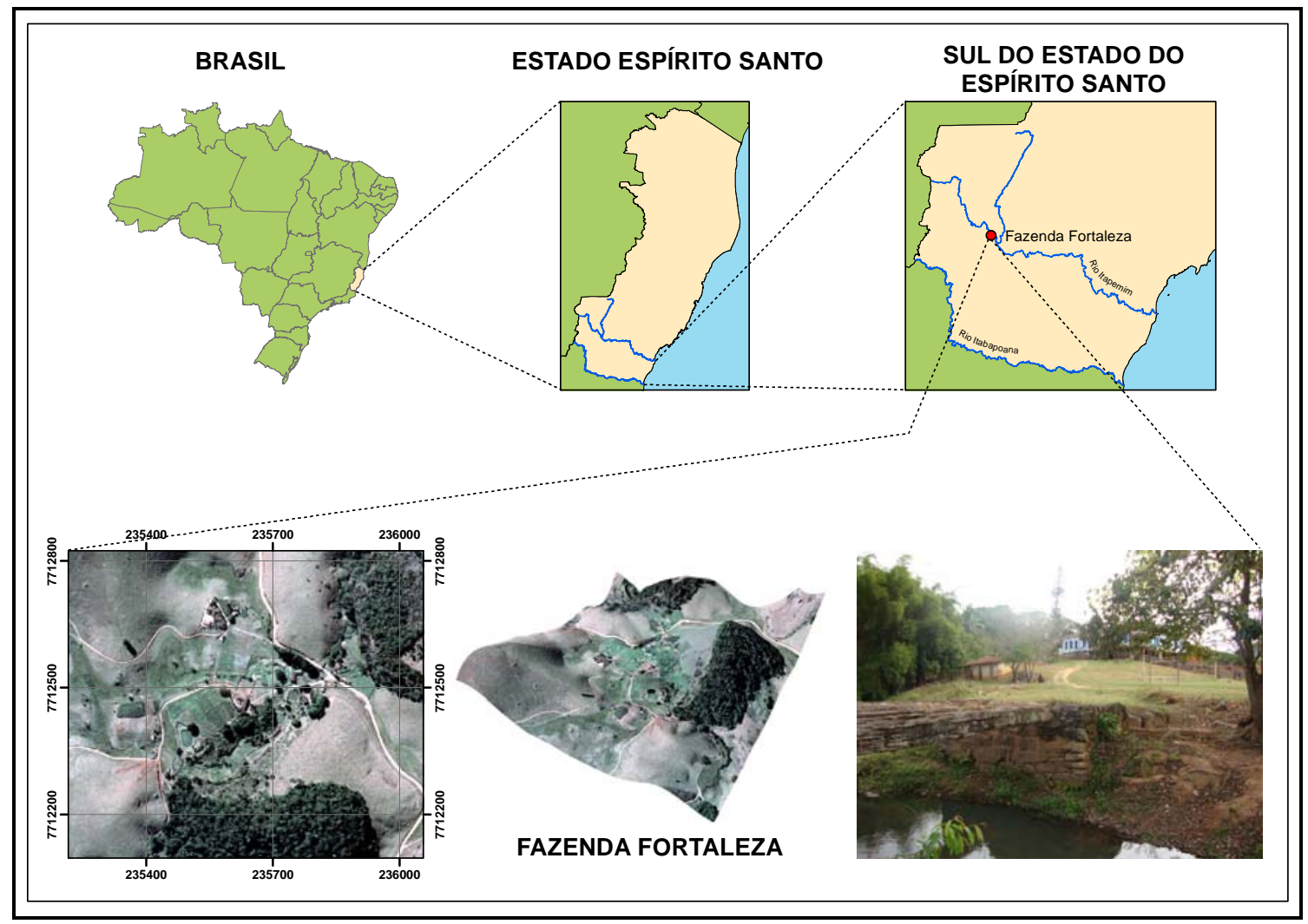

Figura 23. Região entre os rios Itabapoana e Itapemirim e Fazenda Fortaleza, Alegre, ES

Entretanto, é possível considerar o imóvel rural em seus limites reais e tradicionais, além de elementos que compõem sua paisagem, uma vez que as ferramentas em geotecnologia permitem análises em escalas territoriais. Nesse sentido, a distância que determina a área de estudo para a pesquisa em um bem cultural deve ser de tal maneira que não comprometa sua unidade, ou seja, esse bem deverá ser percebido como único e não como partes de um conjunto de elementos fragmentados. Conforme Barbosa (2007), a unidade que concerne ao inteiro não pode ser a unidade que se alcança no total, portanto, o bem cultural deve realizar "um inteiro" e não "um total". 


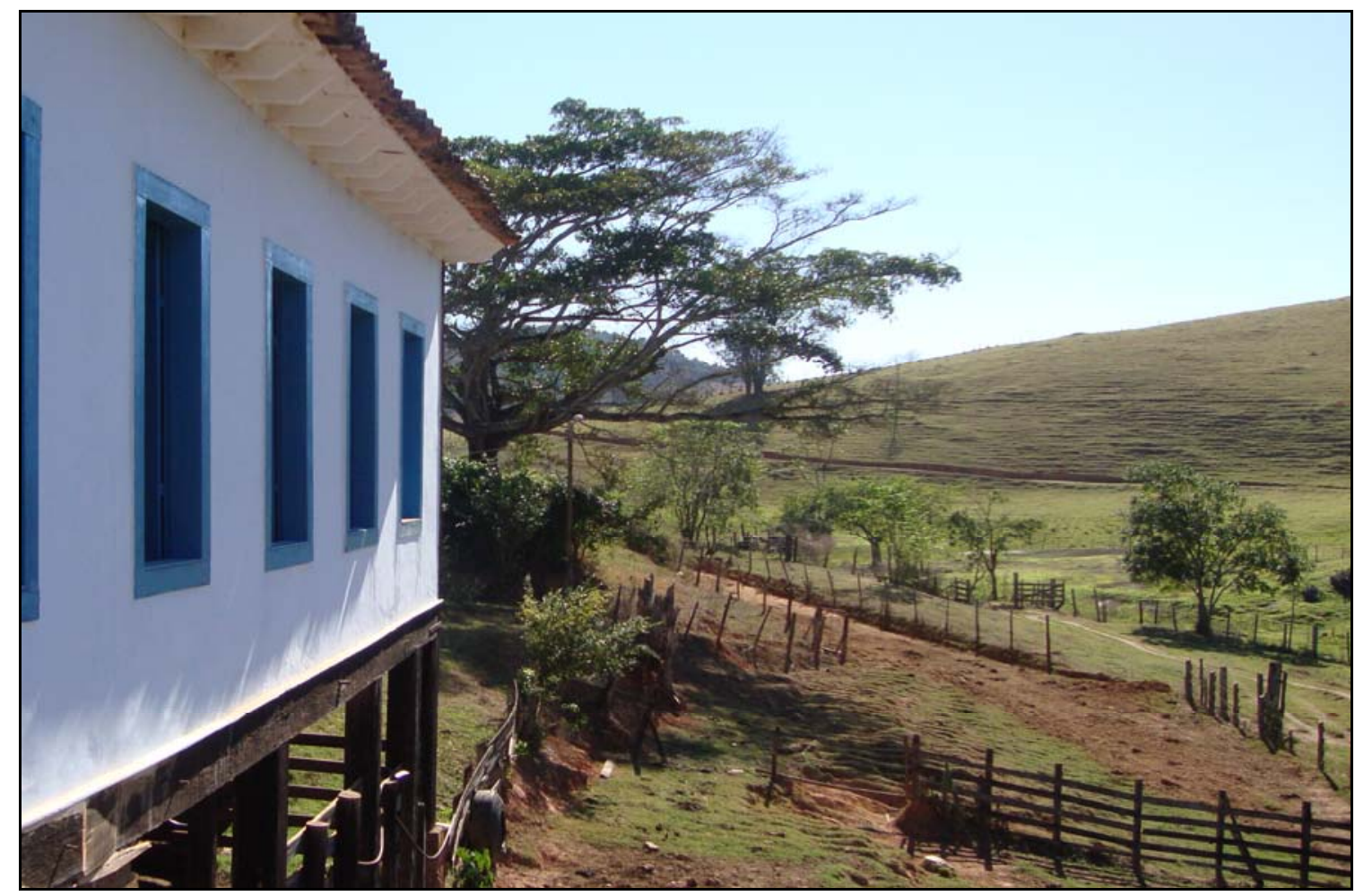

Figura 24. Fazenda Fortaleza, Alegre, ES

Esse caráter de unidade é demonstrado, por exemplo, através de um "mosaico" ou em uma construção arquitetônica feita de "blocos separados". Por analogia, é necessário entender que esse caráter deve ser compreendido em edificações isoladas da fazenda ou em elementos que a constituem como, por exemplo, os caminhos, corpos d'água, pastagem, rocha, onde se possa perceber a diferença entre os elementos reunidos em um total ou conformados em uma unidade na construção do rural como um inteiro. É essencial que se compreenda que na imagem que o bem cultural formula, o mundo do conhecimento obtido por meio dos sentidos aparece reduzido tão só a uma função do conhecimento em meio da figuratividade e da representação de formas reconhecíveis da própria imagem, conforme Figura 25.

Em consequência disso, a imagem de uma escultura em que se vê apenas o busto de um homem, possui apenas o seu tronco, e não pode, por isso, ser considerada mutilada, porque, na verdade, não possui corpo, "pois o que se vê é uma função semântica com respeito ao contexto figurativo que a imagem desenvolve" (BRANDI, 2005). 

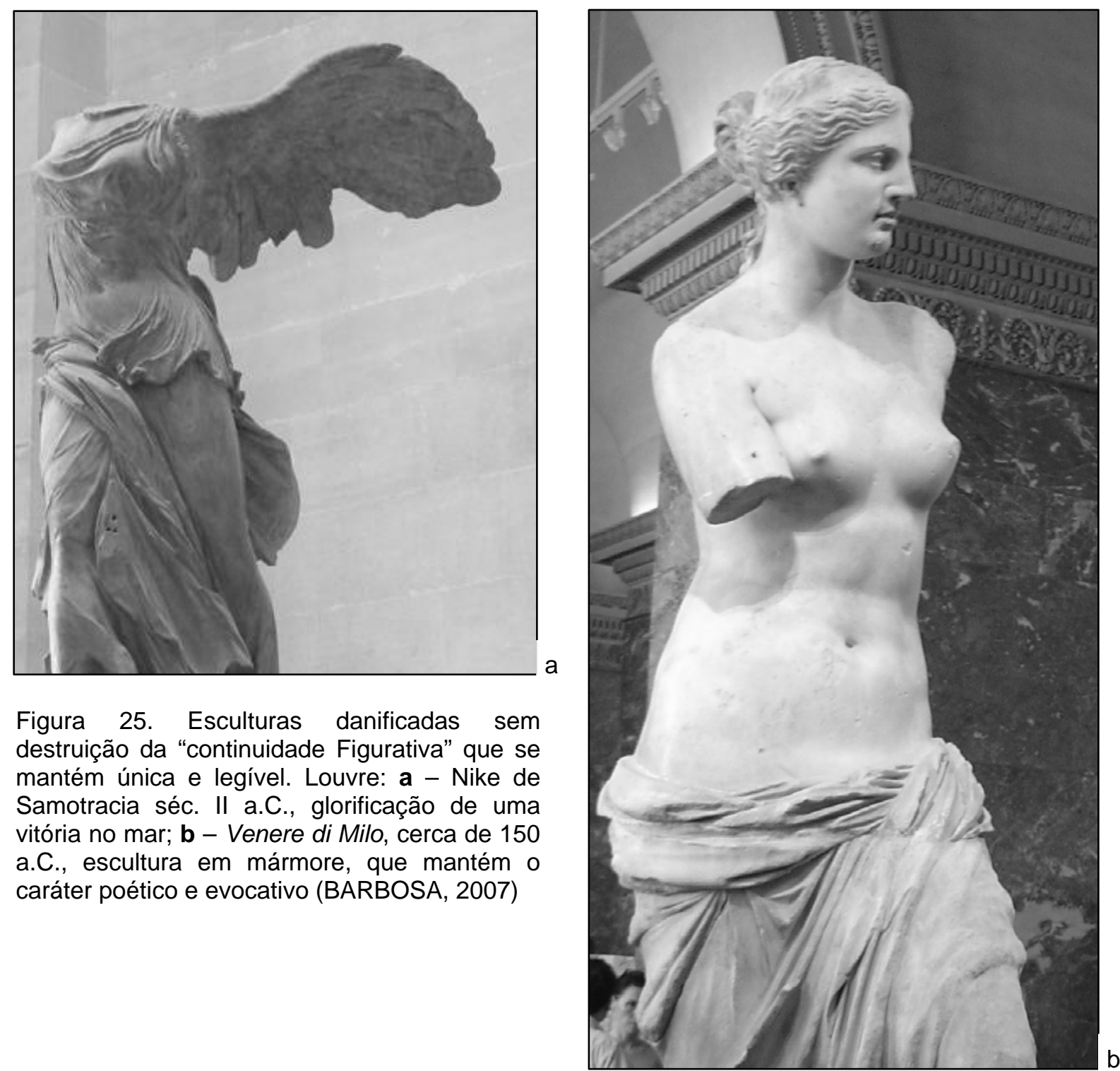

Figura 25. Esculturas danificadas sem destruição da "continuidade Figurativa" que se mantém única e legível. Louvre: a - Nike de Samotracia séc. II a.C., glorificação de uma vitória no mar; $\mathbf{b}$ - Venere di Milo, cerca de 150 a.C., escultura em mármore, que mantém o caráter poético e evocativo (BARBOSA, 2007) $b$

Isso faz perceber que a "unidade orgânico-funcional da realidade existencial" reside nas funções lógicas do intelecto, enquanto a "unidade figurativa da obra de arte se dá concomitantemente com a intuição da imagem como obra de arte" (BRANDI, 2005). Com este encaminhamento dedutivo, o autor elabora a seguinte argumentação reflexiva no que se refere à ciência da conservação de bens culturais:

deduzimos que a obra de arte $^{7}$ não constando de partes, ainda que fisicamente fracionada, deverá continuar a subsistir potencialmente como um todo em cada um de seus fragmentos e essa potencialidade será exigível em uma proposição conexa de forma direta aos traços formais remanescentes, em cada fragmento, da desagregação da matéria.

\footnotetext{
${ }^{7}$ Conforme Beatriz Khul (2006), o conceito de obra de arte na atualidade é sinônimo de bem cultural.
} 
Infere-se que se a 'forma' de toda obra de arte singular é indivisível, e em casos em que na sua matéria, a obra de arte estiver dividida, será necessário buscar desenvolver a unidade potencial originária que cada um dos fragmentos contém, proporcionalmente à permanência formal ainda remanescente neles. (BRANDI, 2005, p.46).

A partir desses dois corolários pode-se entender o que é a unidade potencial de um bem cultural e compreender ainda a negação brandiana de que se possa intervir por analogia na obra mutilada e reduzida a fragmentos. Em sua Teoria, o procedimento de analogia exigiria como princípio a equiparação da unidade intuitiva da obra de arte com a unidade lógica com a qual se pensa a realidade existencial. E, isso é veementemente negado por Brandi (2005).

A arte não seria, portanto, mera reprodução de uma entidade, mas fundaria, ela própria, uma nova entidade, concretizada pelo seu trabalho específico. A realidade seria, aquilo que é instituído pela verdade. Essa instituição é um acontecimento, pois ela nunca é a reprodução do pré-existente e do status-quo, mas que se mantém aberto enquanto a obra de arte existir e for fruída. É do caráter da verdade, portanto, que ela não seja "descoberta" ("descobrir" aqui no sentido de que ela já pré-existiria), como se já existisse em definição no universo, mas de que seja descoberta no sentido de ser desvelada, criada através da instituição desse novo mundo. Isto traz profundas implicações quando trata-se da obra de arte, pois ela, graças ao seu caráter de abertura e de não imutabilidade eterna (afinal a verdade não é pré-estabelecida), se institui a cada vez em que é fruída (CARSALADE, 2007, p.48).

Ao instituir esse mundo, dois pontos são importantes: o seu caráter de ser "real" trazido pela matéria e pelo lugar ("earth") e a noção de "concretização", de "fazer real uma nova realidade" (HEIDEGGER, 1975, p. 45). Sobre o primeiro ponto, "A Origem da Obra de Arte" usa o exemplo do templo grego, onde o contexto em que se coloca e a matéria com que ele é construído são os alicerces sobre os quais se constrói uma nova realidade.

Pelo exame daquilo que é colocado em "Ser e Tempo", tem-se que foi preciso instituir um ente dotado de um privilégio ôntico-ontológico, a pre-sença, para que a fenomenologia pudesse exercer o seu conteúdo como "ciência do ser dos entes", isto é, uma ontologia. Isto significa que a ontologia é o instrumento filosófico que se 
credencia para examinar o sentido do ser em geral: "da própria investigação resulta que o sentido metódico da descrição fenomenológica é interpretação." (HEIDEGGER, 2004, p. 68). Ou seja, para que se possa efetivamente entender o sentido que as coisas estabelecem, devemos nos valer dos métodos interpretativos. (CARSALADE, 2007, p.58)

Essa necessidade ainda se torna mais premente no caso dos estudos desta pesquisa, pois a compreensão do patrimônio depende da interpretação que dele se faz, sobre a qual pesa a distância do tempo e a força da tradição. Para Heidegger (2004), a compreensão é a maneira pela qual a pre-sença se abre para as possibilidades (estas inerentes ao seu ato de projetar-se em direção àquilo que quer compreender) e, antes, é a "forma originária de realização da pre-sença, que é serno-mundo." (GADAMER, 2004, p. 347). Assim, "o projetar da compreensão possui a possibilidade própria de se elaborar em formas. Chamamos de interpretação essa elaboração [...] Interpretar não é tomar conhecimento de que se compreendeu, mas elaborar as possibilidades projetadas na compreensão." (HEIDEGGER, 2004, p. 204). O fenômeno da compreensão ocorre quando as coisas se apresentam com um sentido para o ser, ou seja, quando se estabelece uma ponte entre o ser e os entes que vai além da mera percepção. Assim sendo, o sentido não é algo que se "cola" à presença, mas um existencial característico dela própria, na medida em que, propiciado pela sua abertura, os entes podem nela se revelar. A compreensão, portanto, se constitui na abertura do pré e toda interpretação se funda na compreensão como possibilidade de articulação (HEIDEGGER, 2004, p. 204 a 210). É assim que "a presença se mostra sempre como uma possibilidade" (GALEFFI, 1994, p. 16), e é exatamente essa dimensão da possibilidade que faz com que o caráter hipotético da hermenêutica heideggeriana privilegie sempre as possibilidades sobre as "realidades". A pre-sença é sempre uma possibilidade condicionada pelo ser, seu tempo, sua história e seu modo de determinação. No entanto, apesar dessa multiplicidade a percepção e o conhecimento se dá para os indivíduos de forma integrada, ou seja, dentro de uma possibilidade que integra sujeito e objeto em um único ato.

Para Heidegger (2004), a compreensão é a maneira pela qual a pre-sença se abre para as possibilidades (estas inerentes ao seu ato de projetar-se em direção àquilo que quer compreender) e, antes, é a"forma originária de realização da pre- 
sença, que é ser-no-mundo." Assim, "o projetar da compreensão possui a possibilidade própria de se elaborar emformas. Chamamos de interpretação essa elaboração [...] Interpretar não é tomar conhecimento de que se compreendeu, mas elaborar as possibilidades projetadas na compreensão" (HEIDEGGER, 2004, p. 204). O fenômeno da compreensão ocorre quando as coisas se apresentam com um sentido para o ser, ou seja, quando se estabelece uma ponte entre o ser e os entes que vai além da mera percepção. Assim sendo, o sentido não é algo que se "cola" à presença, mas um existencial característico dela própria, na medida em que, propiciado pela sua abertura, os entes podem nela se revelar. A compreensão, portanto, se constitui na abertura do pré e toda interpretação se funda na compreensão como possibilidade de articulação (HEIDEGGER, 2004, p. 204 a 210). É assim que "a presença se mostra sempre como uma possibilidade" (GALEFFI, 1994, p. 16), e é exatamente essa dimensão da possibilidade que faz com que o caráter hipotético da hermenêutica heideggeriana privilegie sempre as possibilidades sobre as "realidades". A pre-sença é sempre uma possibilidade condicionada pelo ser, seu tempo, sua história e seu modo de determinação. A percepção, o conhecimento ocorre dentro de uma possibilidade que integra sujeito e objeto em um único ato.

\begin{abstract}
Rigorosamente, porém, o que é compreendido não é o sentido, mas o ente e o ser. Sentido é aquilo em que se sustenta a compreensibilidade de alguma coisa. Chamamos de sentido aquilo que pode articular-se na abertura da compreensão. (HEIDEGGER, 2004, p. 208).
\end{abstract}

Conforme Carsalade (2007) as questões ligadas à interpretação se mostram de bastante interesse para o entendimento de como o patrimônio é compreendido pelo ser com que ele se relaciona. Para tanto ele se valer da hermenêutica que, conforme Heidegger, é a ferramenta fenomenológica adequada: "Fenomenologia da pre-sença é hermenêutica no sentido originário da palavra em que se designa o ofício de interpretar" (HEIDEGGER, 2004, p. 68). A investigação ontológica é um modo possível de interpretação caracterizado como elaboração e apropriação de uma compreensão. A situação hermenêutica heideggeriana se constitui exatamente aí, no fenômeno da compreensão: o ente a ser analisado ocupa uma posição prévia e está exposto ao ser que o examina, o qual possui uma visão prévia. Dessa relação resulta uma concepção prévia, a qual delineia uma conceituação, base para a 
interpretação, para a qual se devem dirigir todas as estruturas ontológicas (CARSALADE, 2007).

\subsection{Geotecnologia e preservação cultural}

Moura (2011, p.5), utiliza recursos de Geoprocessamento em análises destinadas ao planejamento urbano, e a gestão do patrimônio histórico, arquitetônico e paisagístico. De acordo com a autora as análises de planejamento urbano promoveram complexa caracterização da realidade urbana de Ouro Preto, identificando limitações e potencialidades de uso, adequabilidade da distribuição das atividades e de infra-estrutura, áreas de risco, assim como a verificação da adequabilidade do Plano Diretor em vigência.

Nos estudos de gestão urbana, Moura (2011) disponibiliza ferramentas para agilizar o cotidiano do monitoramento da cidade, visando a aplicação de programa de armazenamento e gerenciamento da documentação relativa a projetos e intervenções acervo do patrimônio da cidade, e a aplicação de processo que permite a navegação virtual no conjunto urbano e a simulação das intervenções na paisagem. A proposta construída segundo a autora "resgata conceitos da geografia da percepção e propõe modo de análise dentro de critérios reproduzíveis, aplicáveis em diferentes situações, saindo do subjetivismo que sempre marcou a questão do valor do olhar na paisagem"

A adoção de geoprocessamento com diferentes ferramentas de representação e de análises do patrimônio cultural traduz o desejo de incorporação de leitura complexa da realidade e de associação entre "análise assistida por abordagem sistêmica e julgamento visual do usuário, dentro da lógica humana natural de criação de relações entre bagagem de imagens mentais armazenadas na memória e realidade espacial representada de modo virtual" (MOURA, 2010 p.9). 
De acordo com Moura (2010) "O conceito de GED - Gerenciamento Eletrônico de Documentação surge da necessidade de maior produtividade em instituições ou empresas que têm que lidar com o armazenamento e manuseio de grande quantidade de dados de diferentes naturezas (projetos, documentos impressos, fotografias, vídeos, tabelas, entre outros). O objetivo é facilitar e controlar o acesso a documentos em meios digitais. O GED visa eliminar o acúmulo de impressos na rotina da empresa, permitir que as informações sejam acessadas e tratadas mais rapidamente, e promover a criação de acervo de dados com mais segurança em relação ao arquivamento padrão.

Moura (2011, p.2) desenvolve em seu doutoramento estudos que representam importante marco na utilização de geocnologias em patrimônio cultural. Ela propõe a facilitação e o armazenamento de dados relativos a projetos arquitetônicos e urbanísticos já realizados e em andamento no centro histórico de Ouro Preto. Assim como disponibilização de instrumento para gestão do patrimônio histórico, segundo a dinâmica temporal própria das alterações na cidade patrimônio e fornecimento de de instrumento que realize interface entre armazenamento de dados, SIG (com consultas a banco de dados e espacialização das informações em mapas georreferenciados) e verificação visual dos espaços de intervenção pela Navegação Virtual" (MOURA, 2011, p.2). As pesquisas de Moura para o uso de geotecnologia em patrimônio cultural atualmente contemplam questões relativas ao acervo de Serro, MG, Sabará, MG, ambas patrimônio nacional. Deflagrando a diversidade e disponibilidade da ferramenta a temas diversos como o da cultura. De acordo com Moura (2010, p.9)

a Análise de Multicritérios é um procedimento metodológico de cruzamento de variáveis amplamente aceito nas análises espaciais. Ela é também conhecida como Árvore de Decisões ou como Análise Hierárquica de Pesos. O procedimento baseia-se no mapeamento de variáveis por plano de informação e na definição do grau de pertinência de cada plano de informação e de cada um de seus componentes de legenda para a construção do resultado final. A matemática empregada é a simples Média Ponderada, mas há pesquisadores que já utilizam a lógica Fuzzy para atribuir os pesos e notas.

Este procedimento foi o eleito para os estudos desenolvidos para a fazenda Fortaleza, conforme detalah-se ao longo desta pesquisa. Moura (2011) explica ainda 
que a metodologia de análise de multicritérios é bastante adequada para o emprego das geotecnologias na criação de sínteses de variáveis cujo objetivo é a identificação de áreas prioritárias para algum fenômeno ou arranjo geográfico.

O procedimento de análise de multicritérios é muito utilizado em geoprocessamento, pois se baseia justamente na lógica básica da construção de um SIG: seleção das principais variáveis que caracterizam um fenômeno, já realizando em recorte metodológico de simplificação da complexidade espacial; representação da realidade segundo diferentes variáveis, organizadas em camadas de informação; discretização dos planos de análise em resoluções espaciais adequadas tanto para as fontes dos dados como para os objetivos a serem alcançados; promoção da combinação das camadas de variáveis, integradas na forma de um sistema, que traduza a complexidade da realidade; e possibilidade de validação e calibração do sistema, mediante identificação e correção das relações construídas entre as variáveis mapeadas (MOURA, 2011).

\subsubsection{Morfometria para o patrimônio rural}

Para os estudos do ambiente rural da fazenda Fortaleza, utilizou-se como instrumento de mapeamento e identificação a aproximação e o afastamento constante do objeto, evidenciando seus componentes sem, contudo fragmentar o bem cultural como unidade, pautado na manutenção de sua unidade potencial. A fazenda Fortaleza é percebida como única, e para sua compreensão morfológica utiliza-se de instrumentos geotecnificados conforme Santos et al (2010). 


\section{a) Modelo digital de elevação}

A geração de Modelos Digitais de Elevação (MDE) é uma técnica recente dentro das geotecnologias, e tem como objetivo obter uma representação contínua do fenômeno que se pretende estudar a partir de amostras. Historicamente, para geração de modelos era necessário digitalizar os dados topográficos coletados em campo. Essa técnica ainda é aplicada para se gerar MDE, entretanto o elevado custo e velocidade inadequada no processo de geração de imagem, o coloca em substituição por outros métodos automatizados. O conceito atual de MDE, conforme Valeriano (2008), pode ser entendido como "arquivos que contêm registros altimétricos estruturados em linhas e colunas georreferenciadas, como uma imagem com valor de elevação em cada pixel".

Para a fazenda Fortaleza foram adotadas curvas de nível de 20 em 20 metros, em um quadrante de estudo definido a 500 metros a partir da Casa Sede. Na sequência, foi realizada interpolação através do método TIN, das curvas de níveis cortadas. O Modelo Digital de Elevação foi gerado então após a conversão deste relevo TIN para imagem matricial. De posse do MDE, foi possível gerar o perfil topográfico, o mapa de intervalos de elevação; variação da orientação das vertentes; o mapa de sombreamento, mapa de declividade e mapa de direção de fluxo d'água. A partir desses mapas, os dados numéricos foram organizados em gráficos e tabelas para aperfeiçoar as análises das informações obtidas pelos mapas morfométricos, conforme Figura 26. 


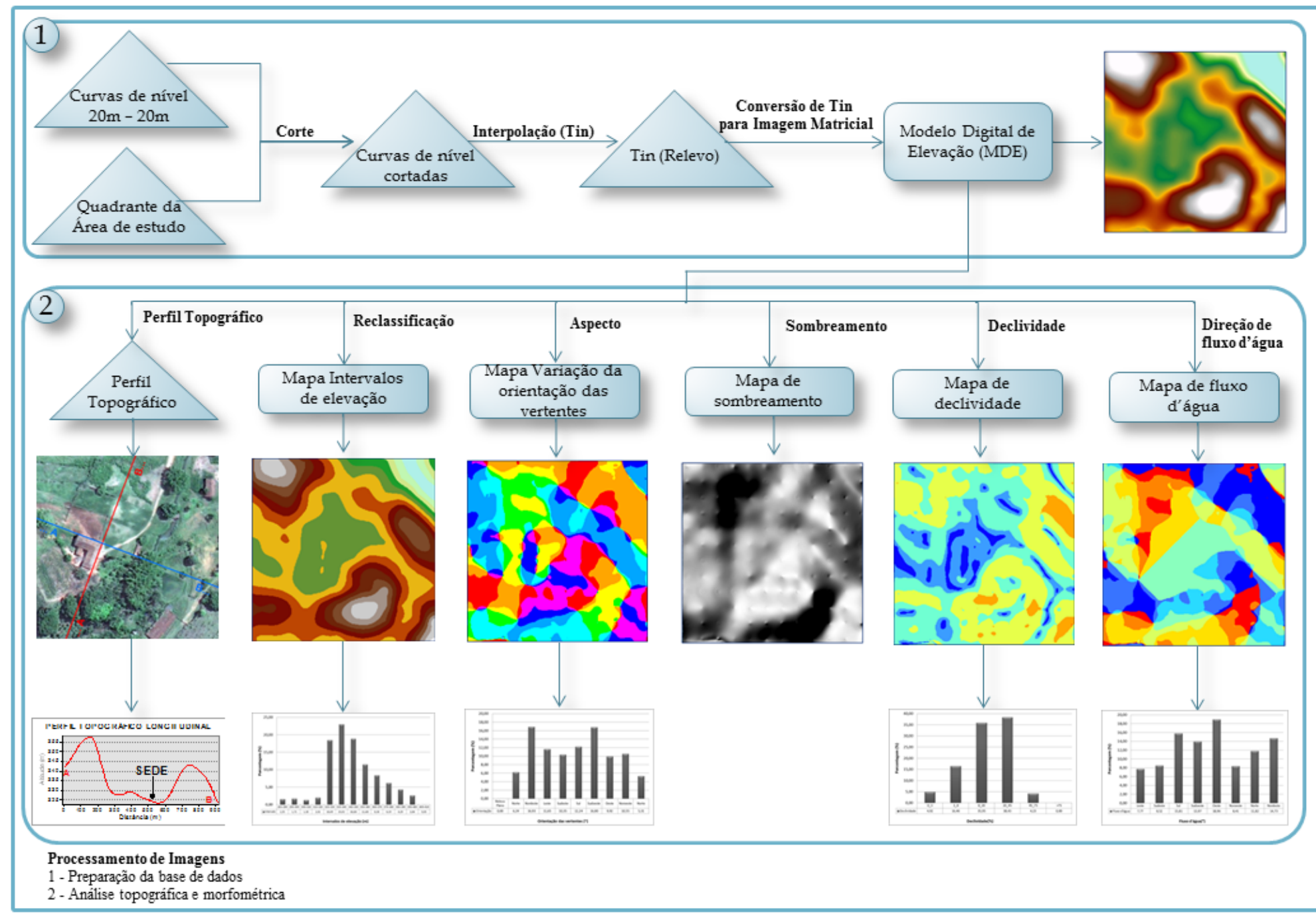

Figura 26. Fluxograma metodológico representativo das etapas necessárias para a elaboração do modelo digital e elevação para o ano 2009 da Fazenda Fortaleza, Alegre, ES. 


\section{Geração do Modelo Digital de Elevação - MDE}

Considerando que o modelo digital de elevação contenha registros altimétricos, representando a variação da elevação, é fundamental a utilização de um recurso que retrate as suas características altimétricas e utilize dados fundamentais na busca de maior refinamento do MDE, que são as linhas de máximo (divisores) e linhas de mínimo (hidrografia). Funciona melhor quando os dados estão distribuídos de forma regular ao longo do domínio (MAZZINI; SCHETTINI, 2009). Assim, para gerar o modelo digital de elevação, é necessário interpolar dados numéricos. Dentre os inúmeros interpoladores existentes para o seu cálculo, neste trabalho, adotou-se o TIN (TRIANGULAR IRREGULAR NETWORK) que é uma variação da Triangulação de Delaunay, descrito por Felgueiras e Goodchild (1995). A Figura 27 ilustra a representação esquemática do modelo. Cabe destacar que esse método preserva as características topográficas, e utiliza importantes dados na busca de um maior refinamento do MDE.

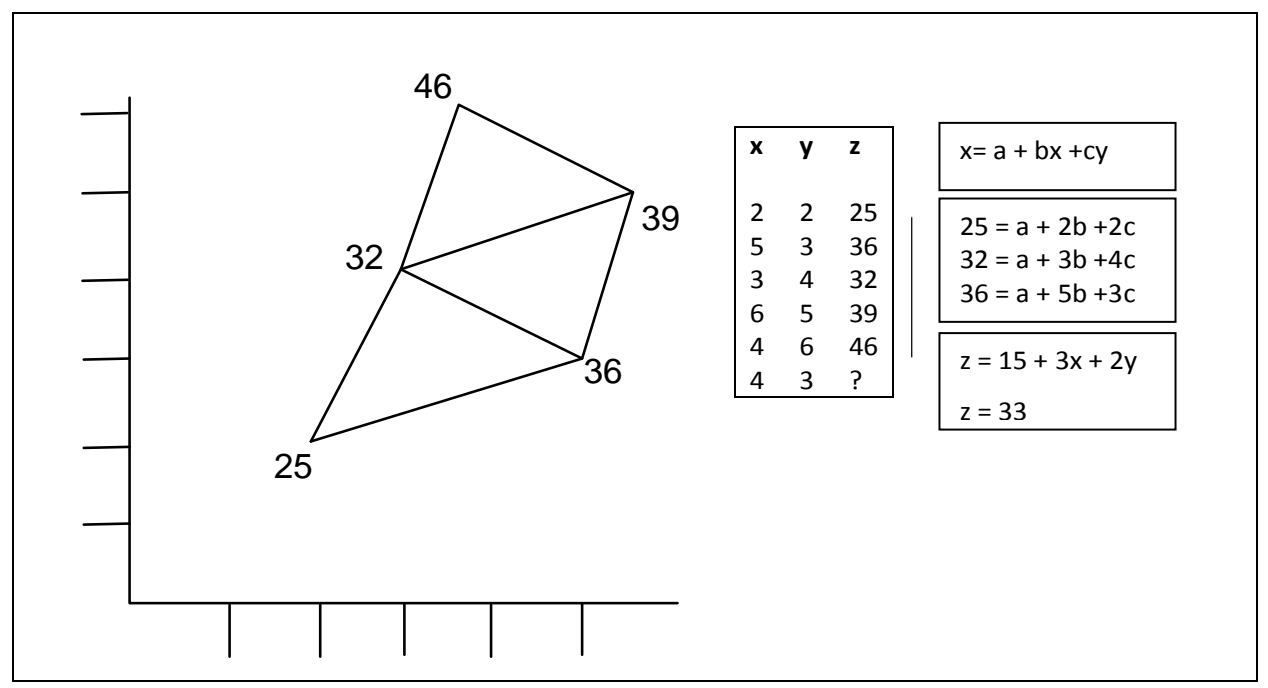

Figura 27. Triangulação de Delaunay

As características topográficas referentes à fazenda Fortaleza foram geradas, considerando-se a definição da área de estudo a partir da sua delimitação pelo quadrante dos 500 metros em relação aos extremos dos beirais da Casa Sede da fazenda, conforme Figura 23. Todos os mapas morfométricos relacionados têm como referência o MDE gerado para a Fazenda Fortaleza nesta área de estudo (Figura 28). 


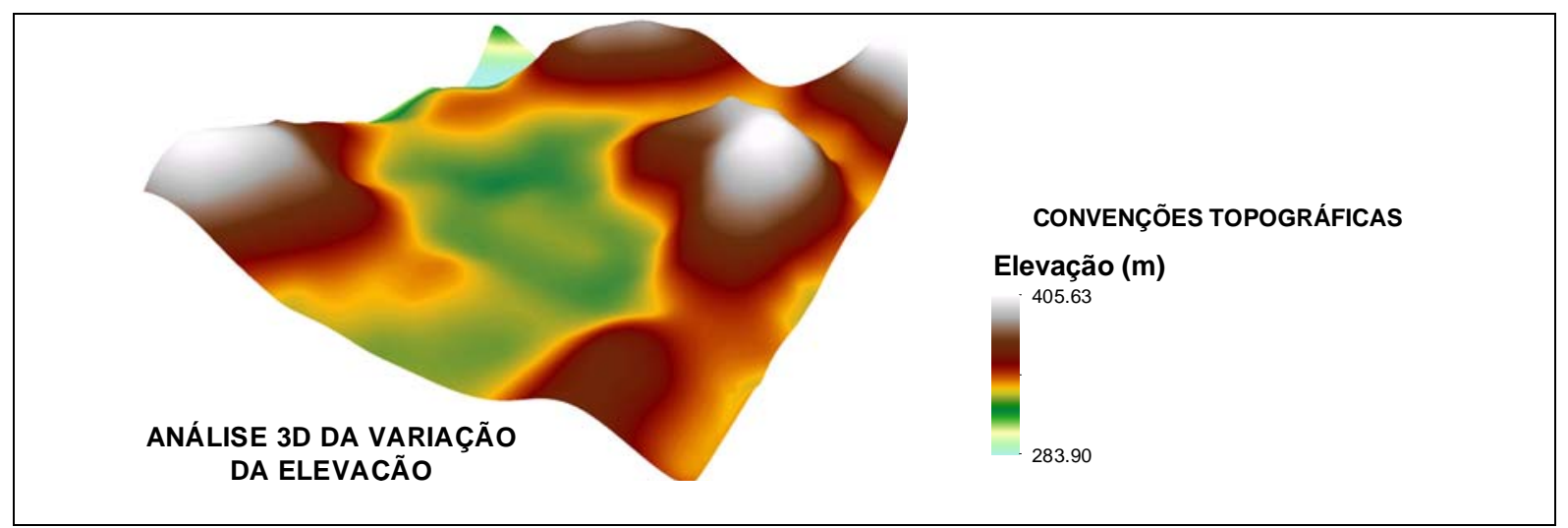

Figura 28. Modelo Digital de Elevação 3D da área de estudo da fazenda Fortaleza.

\section{b) Perfil Topográfico}

A Figura 29 trata da representação de um corte ao longo de uma linha desenhada em um mapa. É como se fosse possível recortar uma porção de terra e separá-la do restante, para assim poder observar lado a lado a superfície recortada, obtendo-se dessa forma o perfil topográfico. Ele é importante para estudar e compreender as relações dos recursos naturais, com as trocas topográficas e o ambiente construído, possibilitando analisar os problemas ou questões existentes.

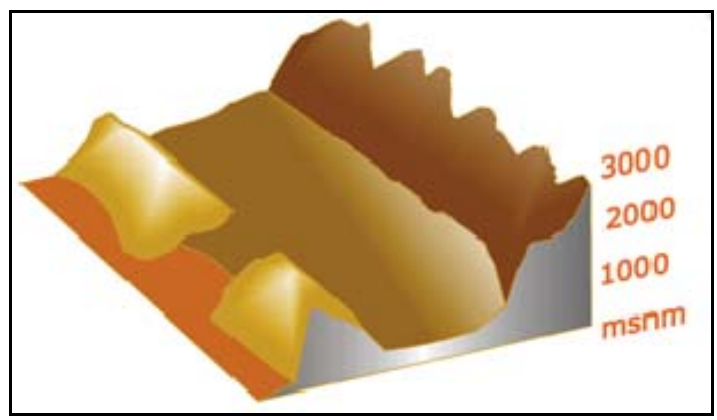

Figura 29. Perfil topográfico 


\section{c) Intervalos de elevação}

A partir do Modelo Digital de Elevação (MDE), conforme Figura 30, foi aplicada a técnica da reclassificação espacial com o objetivo de classificar o MDE em intervalos de grupos iguais a 10 (dez) m. Os intervalos de elevação constituem a representação gráfica do relevo da área de estudo mostrando a variação da cota ou elevação com intervalos de classes definidos de 10 m (SANTOS et al, 2010).

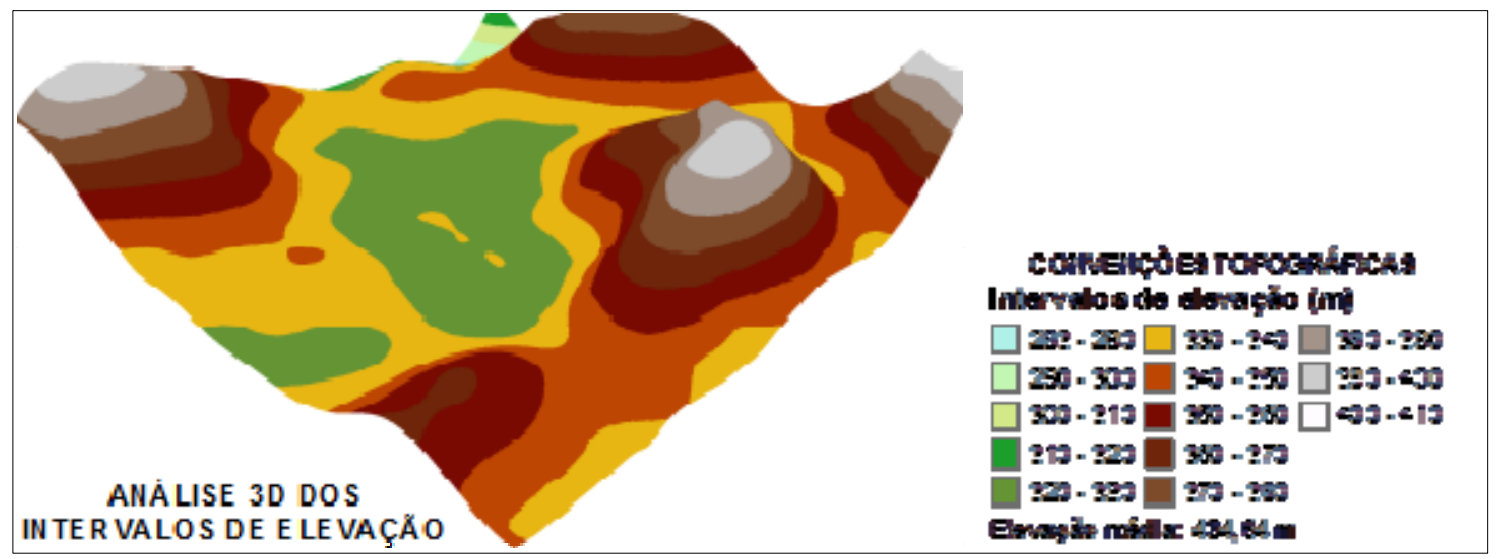

Figura 30. Intervalos de elevação da área de estudo da fazenda Fortaleza

\section{d) Orientação das vertentes}

Esta etapa consiste em elaborar o mapa de orientação do terreno ou mapa de aspecto. A orientação do terreno é definida como sendo o azimute em graus ou ponto cardinal na rosa dos ventos, para o qual se encontra orientado o plano de máxima declividade nesse ponto (SANTOS et al, 2010). Na Tabela 1, estão indicados os pontos cardeais e seus intervalos em graus para a área de estudo da fazenda Fortaleza. 


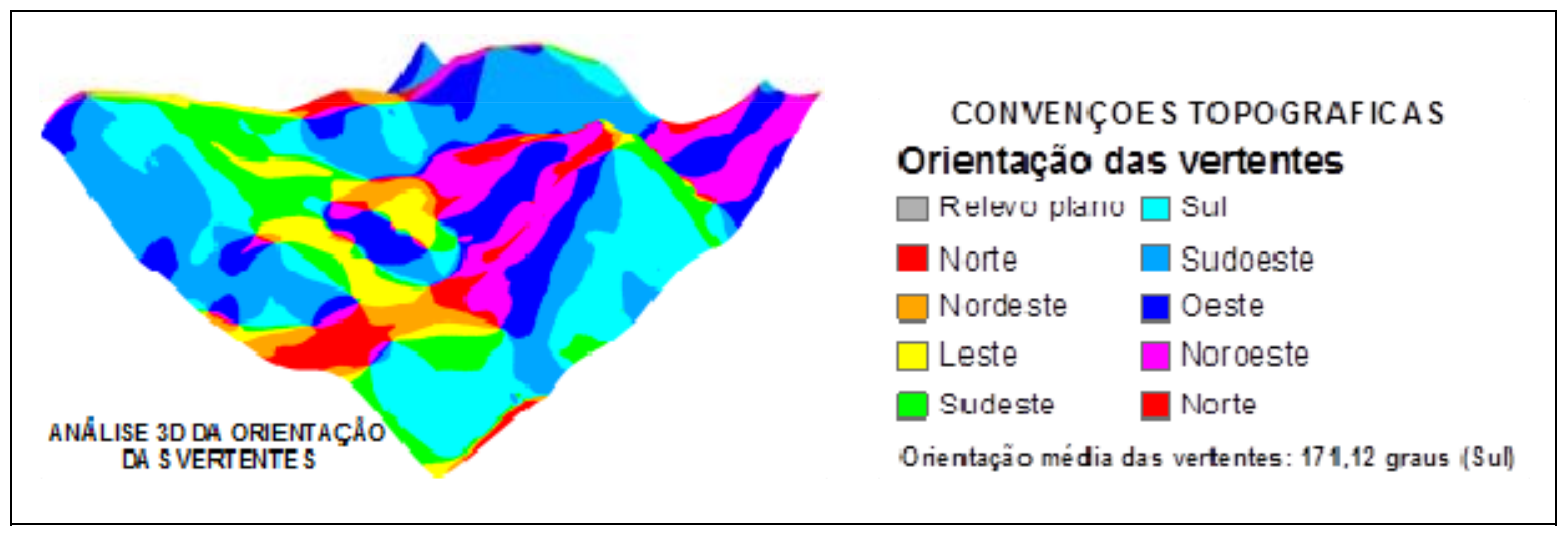

Figura 31. Orientação das vertentes no terreno da área de estudo da fazenda Fortaleza.

Tabela 1. Pontos cardeais e seus intervalos em graus.

\begin{tabular}{lc}
\hline \multicolumn{1}{c}{ PONTOS CADEAIS } & INTERVALO EM GRAUS \\
\hline Norte & $0-22,5$ \\
Nordeste & $22,5-67,5$ \\
Este & $67,5-112,5$ \\
Sudeste & $112,5-157,5$ \\
Sul & $157,5-202,5$ \\
Sudoeste & $202,5-247,5$ \\
Oeste & $247,5-292,5$ \\
Noroeste & $292,5-337,5$ \\
Norte & $337,5-360,0$ \\
\hline
\end{tabular}

O mapa de variação da orientação das vertentes gerado para a área de estudo da fazenda Fortaleza, conforme a Figura 31, é considerado a partir da Rosa dos ventos, que é composta por um gráfico de círculos graduados de $0^{\circ}$ a $360^{\circ}$, onde o exterior indica direções de acordo com os pólos geográficos, conforme Figura 32. O Norte é o $0^{\circ}$, os $90^{\circ}$ correspondem a Leste, os $180^{\circ}$ ao Sul e os $270^{\circ}$ a Oeste. O círculo interior indica as direções em relação ao pólo magnético, o $0^{\circ}$ coincide com a indicação da bússola. O mapa auxiliará na leitura do índice de maior ou menor incidência de terreno, que possui direção conforme os pontos cardeais. 


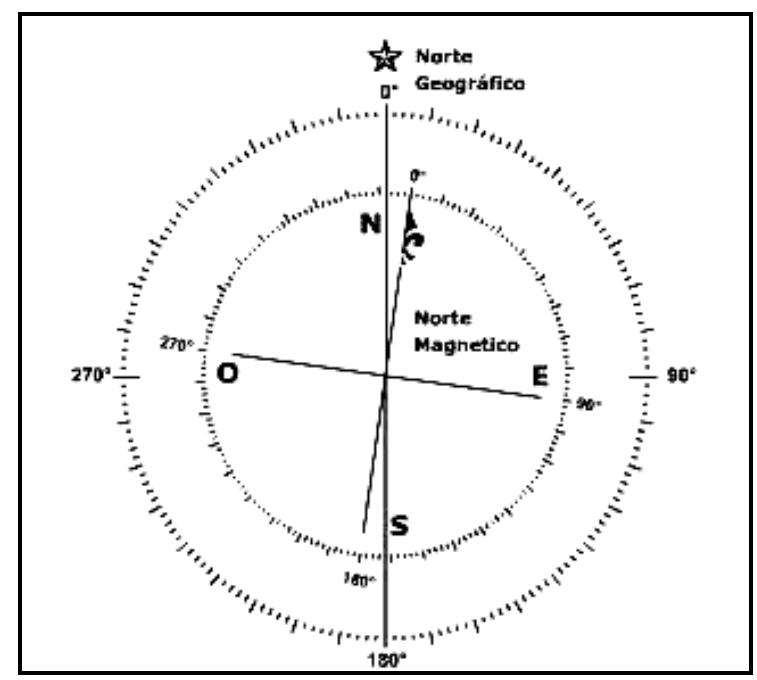

Figura 32. Rosa dos ventos

\section{e) Sombreamento}

Dentre as diversas possibilidades de representar o relevo destaca-se o mapa do sombreamento ou iluminação do terreno. Neste caso, a variável representada é uma simulação do nível de luz, ou de sombra, refletida pelo relevo ao ser iluminado pelo Sol, situado numa posição geográfica determinada. As áreas de maior declividade, que se encontram expostas ao Sol, refletirão muita luz e serão, portanto, muito visíveis; aquelas áreas que se encontram nas encostas não iluminadas diretamente pelo Sol, não refletirão luz e aparecerão escuras no modelo (SANTOS et al, 2010). Como exemplo prático, essa representação do terreno sombreado da fazenda Fortaleza foi obtida através de um ângulo azimutal de 315 graus, ângulo de elevação do Sol de 45 graus às 15 h00 e o MDE, conforme Figura 33.

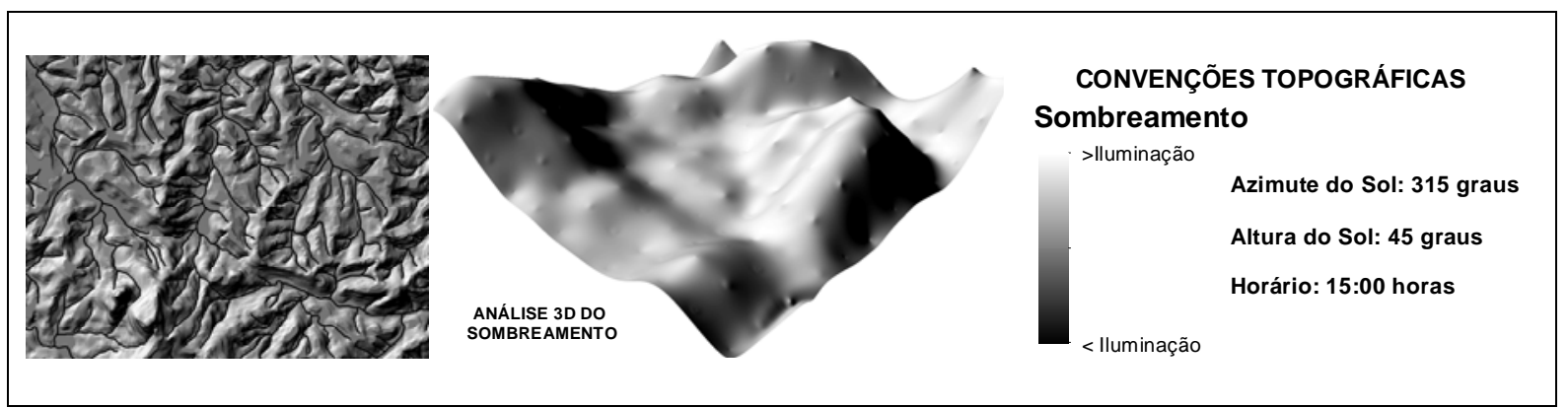

Figura 33. Sombreamento do terreno da área de estudo da fazenda Fortaleza. 


\section{f) Declividade}

Outra possibilidade de representar o relevo é por meio da declividade do terreno que é expressa como a variação de altitude entre dois pontos, em relação à distância que os separa, conforme Figura 34. Para gerar o mapa de declividade, o MDE será utilizado como imagem de entrada. A imagem de declividade gerada será do tipo contínua, por apresentar valores reais. Essa imagem será fatiada e, as classes de declividades serão discriminadas em seis intervalos distintos, conforme parâmetros sugeridos pela Empresa Brasileira de Pesquisa Agropecuária EMBRAPA (1979), assim definidos: 0-3\% (relevo plano), 3-8\% (relevo suavemente ondulado), $8-20 \%$ (relevo ondulado), $20-45 \%$ (relevo fortemente ondulado), $45-75 \%$ (relevo montanhoso), e, $>75 \%$ (relevo fortemente montanhoso), Figura 34. Entretanto, existe a possibilidade de se dividir o terreno em outras classes de declividade, de acordo com as necessidades de cada estudo (SANTOS et al, 2010). Neste trabalho, essa operação contempla a técnica de reclassificação com base numa tabela ASCII, gerada para este propósito. A estrutura utilizada com o comando que foi realizado está na Tabela 2.

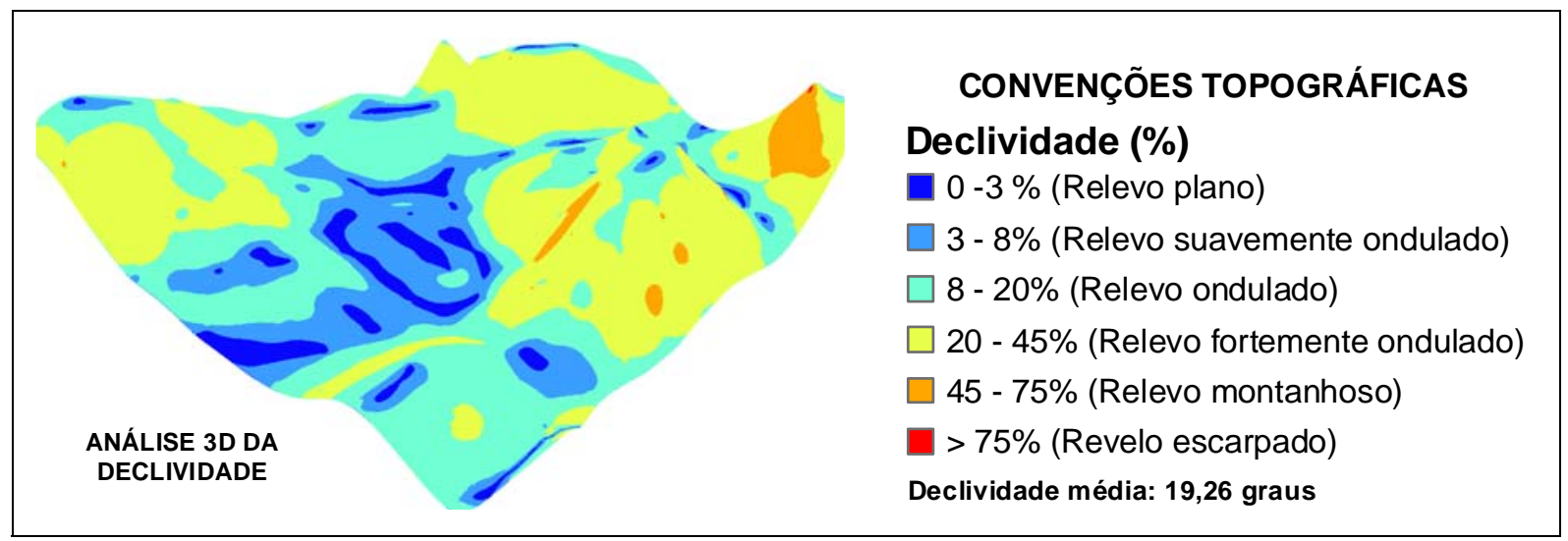

Figura 34. Modelo e 3D do terreno da área de estudo da fazenda Fortaleza. 
Tabela 2. Declividade e a classificação do respectivo relevo

\begin{tabular}{cc}
\hline $\begin{array}{c}\text { DECLIVIDADE EM PORCENTAGEM } \\
\mathbf{( \% )}\end{array}$ & RELEVO \\
\hline $0-3 \%$ & plano \\
$3-8 \%$ & suavemente ondulado \\
$8-20$ & ondulado \\
$20-45 \%$ & fortemente ondulado \\
$45-75 \%$ & montanhoso \\
$>75 \%$ & fortemente montanhoso \\
\hline
\end{tabular}

\section{g) Direção de fluxo de escoamento da água}

Após a correção do MDE, pode-se determinar a direção do fluxo de escoamento da água (Figura 35), baseando-se nas direções do escoamento para cada célula que compõem o MDE já corrigido anteriormente. A imagem matricial de direção de fluxo é representada pelos códigos 1, 2, 4, 8, 16, 32, 64 e 128 que depende da direção do escoamento da água das maiores para as menores elevações do MDE, conforme ilustra a Figura 36 (SANTOS et al, 2010).

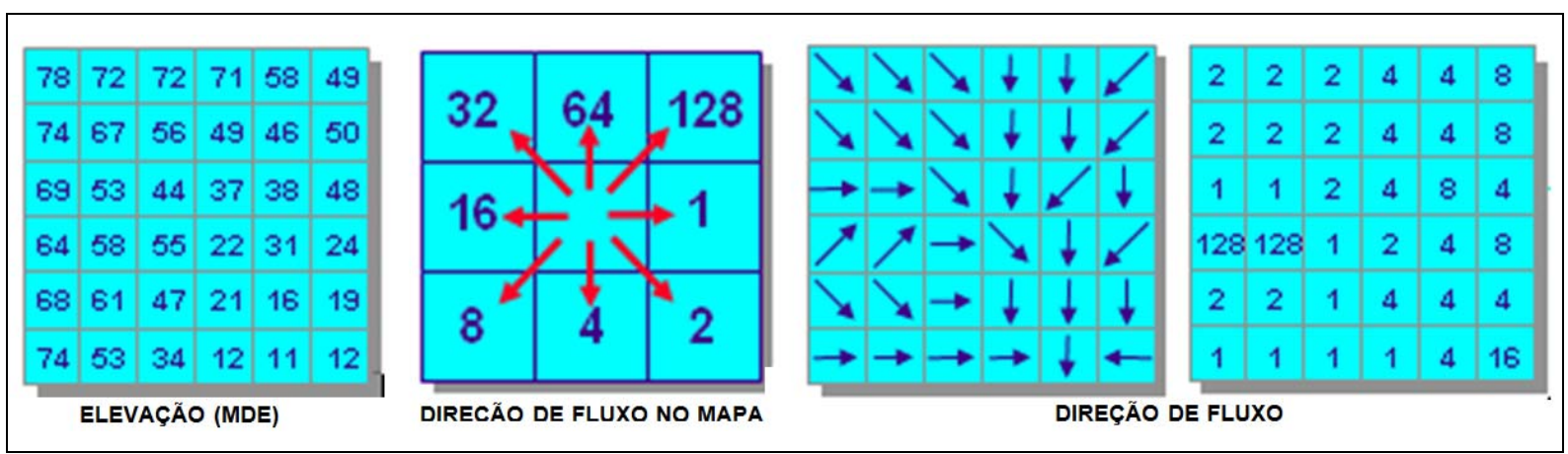

Figura 35. Representação matricial da direção do fluxo d'água. 


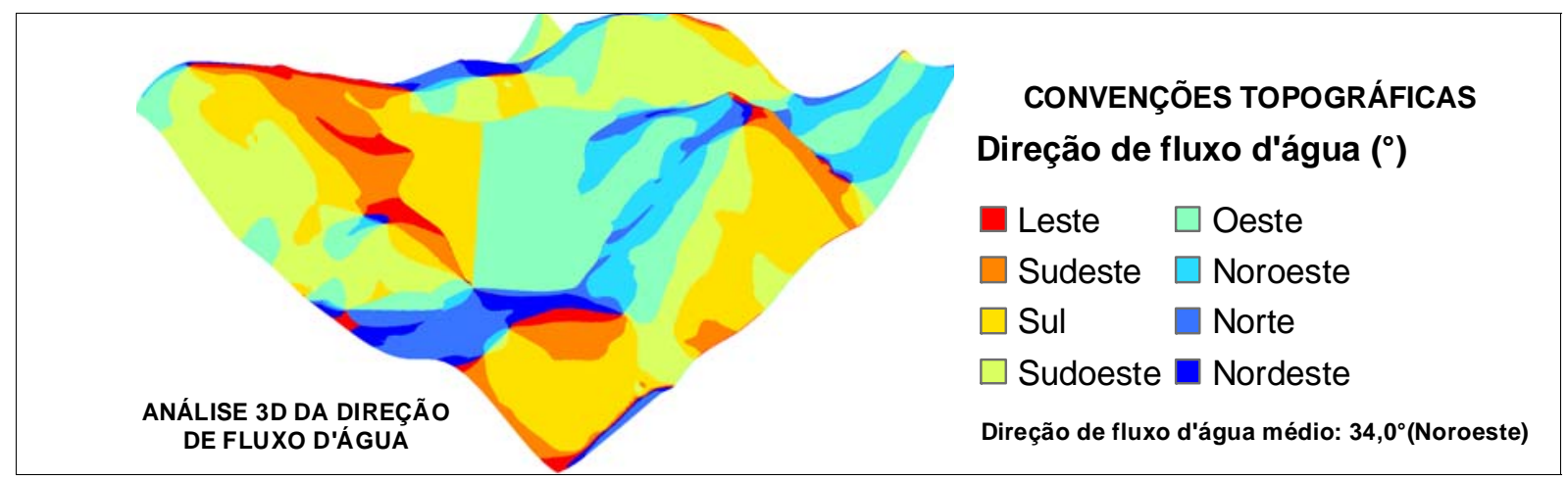

Figura 36. Direção do fluxo d'água no terreno da área de estudo da fazenda Fortaleza.

\subsubsection{Evolução do uso da terra para os anos de 1970 e 2009}

No que se refere à evolução do uso da terra, cabe destacar que os objetos mudam ao longo do tempo. Todos os dados geoespaciais estão variando de momento em momento relativamente ao uso e ocupação da terra e localizações dos objetos (GRANZINOLLI, 2009). Estão ocorrendo avanços tecnológicos na coleta de dados geoespaciais como monitoramento de animais selvagens e de dinâmira de erupções vulcânicas. Tais avanços devem ser observados e incorparados na área de patrimônio cultural. Estudos de Granzinolli (2009) mapeiam o levantamento da área de vida, uso e seleção de habitat de aves de rapina na região central do estado de São Paulo com monitoramento de seis aves de rapina por rádio-telemetria. A que se ter claro ainda, as relações entre o uso da terra e o objeto em si, por exemplo, para se descobrir padrões de áreas desmatadas e como esses padrões evoluem no tempo é importante ter o conceito de objeto (área desmatada) e de evolução desse objeto ao longo do tempo (GRANZINOLLI, 2009). O autor ainda destaca que esta organização da informação espacial permitiu que variáveis diversas fossem integradas ao banco de dados e que estudos diferentes fossem realizados, combinando tão somente os fenômenos de interesse. 
Assim, acredita-se que o estudo do patrimônio rural e o impacto das condições ambientais em sua permanência às gerações futuras, bem como suas características ambientais atuais frente ao que já foi em um tempo anterior, gerem níveis de informação preciosas diante da relação entre o ambiente construído e a paisagem que o constitui. Para os estudos da fazenda Fortaleza, considera-se que a aerofoto IEMA 2007/2008, abrange todo o estado do Espírito Santo. É fruto do convênio "VALE DE QUALIDADE AMBIENTAL" celebrado entre a Companhia VALE e o Governo do Estado, este representado pelo IEMA. As aerofotos, formadas pela articulação de cerca de 540 blocos de imagens de $10 \times 10$ km, são constituídas de imagens de alta qualidade, muito úteis para a identificação e mapeamento de feições geográficas e do uso e cobertura da terra. Segundo o Instituto Brasileiro de Geografia e Estatística - IBGE, (2006) os levantamentos de uso e da cobertura da terra indicam a distribuição geográfica da tipologia de uso, que pode ser identificada por meio de padrões homogêneos da cobertura terrestre; devendo estes estudos ser considerados como importantes instrumentos para a construção de indicadores ambientais e para a avaliação da capacidade de suporte ambiental, visto que proporcionam o conhecimento dos diferentes manejos empregados e identificam alternativas que permitam o desenvolvimento sustentável. Devido a sua importância, os levantamentos de uso e ocupação da terra são largamente realizados.

Trabalhos por meio de técnicas de fotointerpretação já eram realizados em 1952, 1962, 1980 e 1996 baseadas em vôos, e trabalhados em diferentes escalas (CANEPARO, 2001). Rangel et al. (2001) mapeou mudanças de uso e cobertura vegetal por meio de imagens Landsat-5 TM, dados ERS-1/SAR e do uso da classificação supervisionada ocorridas nos manguezais do município Raposa (MA) entre 1984 e 1995. Os autores analisaram o uso e cobertura vegetal presentes nas imagens. Foi ainda realizado estudo com o objetivo de quantificar e caracterizar espacialmente a mudança na cobertura de terra no período de 1956 a 1998, nas regiões de Cacheu e Orango, Guinea-Bissau. Os pesquisadores salientaram que a diferença das fontes de dados disponíveis para os dois anos limitaram a interpretação dos resultados, contudo os resultados dessa pesquisa apontaram a necessidade de um plano de manejo sustentável nas áreas estudadas, visto que a maior modificação observada entre as classes no período de tempo estabelecido ocorreram em Cacheu, região de maior área populacional (VASCONCELOS et al. 
2002). Outro estudo de destaque contempla o desenvolvimento de uma metodologia para a delimitação de unidades de conservação ambiental, utilizando técnicas de fotointerpretação e fotogrametria digital. O método aborda o levantamento de dados e materiais já existentes, análise e digitalização dos originais fotográficos do vôo (captura dos dados do meio analógico para o meio digital), levantamento e utilização dos pontos de controle terrestres, aerotriangulação e geração dos modelos estereoscópicos, restituição e fotointerpretação digital dos limites do mangue. A metodologia se mostrou altamente aplicável a outras unidades de conservação, sendo que, para unidades de maiores dimensões, imagens de alta resolução, advindas de sensores orbitais, devem ser consideradas (LEMOS et. al. 2004).

Ratcliff e Henebry (2005) estudaram o aumento da densidade urbana de Almaty, Cazaquistão, por meio de aerofotos dos anos de 1964, 1966, 1968 e 1971, e de uma imagem do satélite quickbird do ano de 2002. Os autores utilizaram a interpretação visual e digitalizaram manualmente as mudanças ocorridas na área de estudo, assim observaram a transformação da ocupação do espaço a partir da mudança das edificações de pequena para grande porte. Estudos realizados por Holland et. al. (2006) abordam a substituição de aerofotos por imagens de satélite no desenvolvimento e atualização de mapas topográficos. Os autores verificaram que a imagem quickbird, quando comparada a aerofotos na escala 1:50000, possibilita número maior de feições, porém mapeou menos feições quando comparada as aerofotos na escala 1:25000. Além disso, para essa última escala, a exatidão e fidelidade geométrica são mais complexas. Ginak et. al. (2007) utilizaram as bandas verde, vermelho e azul de uma imagem do satélite quickbird do ano de 2006 para mapear o uso e ocupação da terra de uma ilha fluvial, localizada entre Ilha Solteira (SP) e Selvíria (MG), com o uso da fotointerpretação e da digitalização manual (via tela). Foram classificados seis usos da terra para a região: capoeira, capoeira rala, campo alagadiço, campo-cerrado, uso antrópico e solo exposto. Verificaram que a composição colorida do satélite possibilitou observação de detalhes da vegetação.

Entende-se que em mapeamento de uso da terra, quanto mais completo o padrão de ocupação, maior a heterogeneidade do tamanho das edificações, e quanto maior a variedade dos materiais de cobertura e a ausência de um arranjo espacial bem definido, pior será a exatidão temática dos resultados (PINHO et al 2007). De acordo com fluxograma ilustrado pela Figura 37, a partir das imagens 
digitais, georreferenciadas e cortadas, relativas aos anos de 1970, 2007 e 2009, foi realizada fotointerpretação em tela das classes de uso da terra, em conformidade com a classificação do IBGE (2006), como é possível observar na Tabela 3. No ambiente do aplicativo computacional ArcGis 10, realizou-se a dissolução de polígonos, gerando as classes de uso da terra dissolvidas, o que possibilitou a leitura das áreas em hectares e em porcentagens da incidência de cada uso da terra, ocasionando o conhecimento dos diferentes manejos empregados, o que permite a identificação de opções que contribuirão para um desenvolvimento adequado do meio ambiente. A fotointerpretação em tela para se obter o mapa de uso da terra, foi adaptada das classes de uso apresentadas pelo IBGE (2006) (Tabela 3), e adotaram-se as imagens ortofotomosaicaidas do IEMA na escala de 1:35000 e trecho específico a 350 m de altitude da imagem GeoEye de satélite do Google Earth do ano de 2009. Além disso, adotou-se também a utilização de aerofoto analógica escaneada em alta resolução da área de estudo referente ao ano de 1970, cedido pelo Instituto de Defesa Agropecuária e Florestal do Espírito Santo IDAF (1970). Essas fotos digitalizadas foram mosaicadas e a partir da associação do sistema de projeção, a aerofoto digital, ou imagem digital, foi georreferenciada e posteriormente cortada. Essa aerofoto ou imagem digital foi fotointerpretada em tela, possibilitando o mapeamento da imagem em classes do uso da terra, que após dissolução de polígonos possibilitou o cálculo de áreas em hectares e porcentagem de uso da terra conforme Figura 37. 
Tabela 3. Classes de uso da terra de referências para fotointerpretação na fazenda Fortaleza, Alegre, ES.

\begin{tabular}{|c|c|c|}
\hline CLASSE & TEXTURA & DESCRIÇÃO \\
\hline Floresta & & Todas as áreas verdes com presença de vegetação arbórea \\
\hline Café & & $\begin{array}{l}\text { Área utilizada para o cultivo da cultura do café. Lavoura permanente e } \\
\text { intermitente: cultura de ciclo longo e curto que permite colheitas sucessivas, } \\
\text { com ou sem necessidade de novo plantio a cada ano. }\end{array}$ \\
\hline Pastagem & & $\begin{array}{l}\text { Áreas utilizadas pela pecuária e ainda áreas cobertas por gramíneas, sem } \\
\text { uso definido; nessas áreas o solo está coberto por vegetação de gramíneas } \\
\text { ou leguminosas, cuja altura pode variar de alguns decímetros a alguns } \\
\text { metros. }\end{array}$ \\
\hline Solo exposto & & $\begin{array}{l}\text { Todos os solos descobertos, sem a presença de área verde ou } \\
\text { construções, área sem nenhuma vegetação. }\end{array}$ \\
\hline Rocha & & $\begin{array}{l}\text { Consideraram-se todas as formações rochosas como áreas com presença } \\
\text { contínua de rochas. }\end{array}$ \\
\hline $\begin{array}{l}\text { Área } \\
\text { agriculturada }\end{array}$ & & $\begin{array}{l}\text { Área destinada ao cultivo de culturas agrícolas de curta ou média duração, } \\
\text { geralmente com ciclo vegetativo inferior a um ano, que após a produção } \\
\text { deixa o terreno disponível para novo plantio. }\end{array}$ \\
\hline $\begin{array}{l}\text { Edificações e } \\
\text { instalações rurais }\end{array}$ & & $\begin{array}{l}\text { Área de construção civil isolada, como casas, currais, galpões etc., } \\
\text { incluindo-se benfeitorias do entorno como quintais etc. }\end{array}$ \\
\hline Rios e lagos & & Presença de córregos, rios, lagoas e reservatórios. \\
\hline $\begin{array}{l}\text { Estrada não } \\
\text { pavimentada }\end{array}$ & & Estradas rurais, não asfaltadas. \\
\hline
\end{tabular}

Fonte: Adaptado de IBGE (2006); Imagens: Ortofotomosaico IEMA, Escala 1:35000 


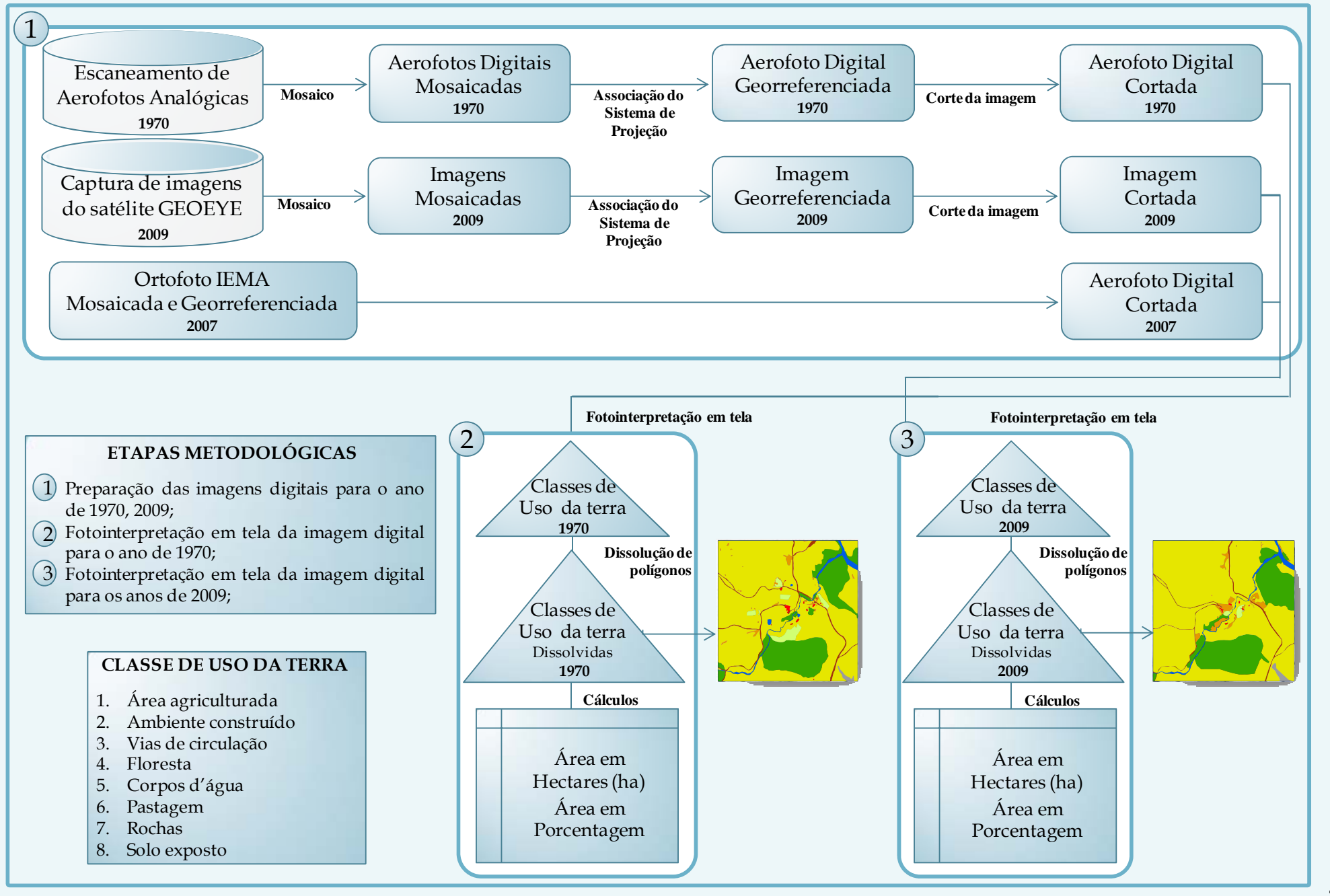

Figura 37. Fluxograma metodológico representativo das etapas necessárias para a elaboração dos mapas e uso da terra para os anos de 1970 e 2009 da fazenda Fortaleza, Alegre, ES. 


\subsubsection{Sensibilidade Cultural para o ambiente rural: um conceito}

No passado, o entendimento de "Monumento Histórico" era utilizado para se referir a obras espetaculares. Na atualidade, esse conceito se aproxima mais da origem do termo Monumento, conforme Alois Riegl, mostrando-se como dispositivo da memória coletiva e de bens históricos. A preservação de bens culturais, tal como entendida hoje, tem raízes remotas.

É possível detectá-las no século $X V$, quando, de forma paulatina, as intervenções em obras de épocas passadas deixam de ter como moventes questões de ordem essencialmente prática e utilitária e começam a ter motivação cultural. A partir de finais do século XVIII a preservação vai se sistematizar, assumindo, de forma gradativa, uma maior autonomia e consolida-se como campo disciplinar autônomo principalmente a partir do século XX (KÜHL, 2006, p.3).

Percebe-se que as produções vinculadas ao tema da preservação, como princípios e preceitos, estão fundamentadas em pelo menos 200 (duzentos) anos de sólidas e respeitadas experimentações. Mas deve-se ter atenção, pois divergências são constantes, apesar de não impedir preciosas discussões e contribuições criteriosas para a área, proporcionando ao tema da preservação importantes instrumentos de reflexão (BARBOSA, 2007). No que se refere à arquitetura, Feilden (1982) afirma que o trabalho de preservação requer tratamento de materiais em um ambiente aberto e virtualmente incontrolável, onde devem ser permitidos os efeitos do tempo.

Camillo Boito trouxe questões como a distinguibilidade e a ênfase ao valor documental dos monumentos, e Alois Riegl, no final século XIX e início do século $\mathrm{XX}$, apresentou novidades tanto para a teoria quanto para a prática da preservação e restauração dos bens culturais, contemplando aspectos normativos na Áustria, além de análises profundas sobre o papel dos Monumentos Históricos e suas formas de apreensão por uma dada sociedade.

Riegl deu passos fundamentais para consolidar a preservação de bens culturais como um campo disciplinar autônomo, que deixou de ser apenas um "auxiliar" da história da arte (assim como também contribuiu para a consolidação da própria história da arte como um campo autônomo em relação à 
"história geral"), passando a assumir características próprias, podendo, por sua vez, oferecer contribuições para a própria historiografia e para a criação artística contemporânea. Elaborou proposições prospectivas, que permanecem válidas ainda hoje, contendo elementos que podem ser continuamente explorados (KÜHL, 2006, p.5).

Cabe destacar ainda que Riegl foi um dos primeiros a evidenciar que as atuações voltadas à preservação dos Monumentos Históricos não podiam ser entendidas em sentido absoluto; para ele, não existe uma única solução universalmente válida, mas várias soluções de pertinência relativa. Entretanto, isso não significa que a ação seja arbitrária, pelo contrário (KÜHL, 2006). Trata-se de respeito à obra de arte. Para Brandi (2005), é na imagem que a obra de arte se formula, não reduzida somente a uma função do conhecimento em meio da figuratividade desta imagem, pois nessas condições, qualquer postulado de integridade orgânica se dissolve. Assim, ele afirma que "a imagem é verdadeiramente e somente aquilo que aparece: a redução fenomenológica que serve para indagar o existente torna-se, na Estética, o próprio axioma que define a essência da imagem" (BRANDI, 2005, p.44). A manifestação, ou percepção da natureza, ou do significado essencial da imagem, é mostrada através da matéria. Pode-se dizer que a fenomenologia ${ }^{8}$ estabelece a importância dos fenômenos da consciência - os quais devem ser estudados em si mesmos - e que tudo que podemos saber do mundo resume-se a esses fenômenos, a esses objetos e ideias que existem na mente, cada um designado por uma palavra, que representa a sua essência, sua significação.

Os objetos da fenomenologia "são dados absolutos apreendidos em intuição pura, com o propósito de descobrir estruturas essenciais dos atos (noesis) e as entidades objetivas que correspondem a elas (noema)" (COBRA, 2005, p.1). Ou seja, a fenomenologia trata do estudo da consciência e dos objetos da consciência, a redução fenomenológica. De acordo com Cobra (2005), trata do "[...] processo pelo ciência rigorosa, procurando dar raciocínio filosófico em relação às coisas variáveis do mundo real. Para ele, trata-se de um "método filosófico que se propõe a uma descrição da experiência vivida da consciência, cujas manifestações são expurgadas de suas características reais ou empíricas e consideradas no plano da generalidade essencial [Reconhecida como uma das principais correntes filosóficas do século XX, influenciou autores como Heidegger (1889-1976), Sartre (1905-1980) e Merleau-Ponty (1908-1961).]". (Houaiss, 2001, verbete da Rubrica: filosofia). 
qual tudo que é informado pelos sentidos é mudado em uma experiência de consciência, em um fenômeno que consiste em se estar consciente de algo", podendo se referir a imagens, coisas, fantasias, atos, relações, pensamentos, sentimentos e demais constituições de experiências da consciência. Para a fenomenologia, o mais relevante não é o que existe no mundo, mas sim, o modo como o conhecimento do mundo acontece e se realiza para o indivíduo, onde a "redução fenomenológica" significa restringir o conhecimento ao fenômeno da experiência da consciência, importando prioritariamente a visão de mundo que cada um tem. Nesse contexto, a percepção, assim como o pensamento, se faz nas coisas, considerando-se que pensar consiste em se reinstalar no ato da visão. Dessa forma, de acordo com Merleau-Ponty (1999), a cada instante da existência estamos integrados ao mundo por meio de nosso corpo. Sendo essa a nossa condição, temos que reavaliar o fenômeno da percepção e perguntar como percebemos o mundo e, mais, devemos inquirir se podemos pensá-lo sem antes percebê-lo. Para Beatriz Kühl (2006), a partir da fenomenologia é possível deixar-se penetrar em um bem cultural e no processo que o produziu, examinando-o em sua plenitude formal, buscando, por assim dizer, sua realidade ontológica.

Em Ser e tempo destaca que:

a expressão fenomenologia significa, antes de mais nada, um conceito de método [...]. O termo expressa um lema que poderia ser assim formulado: voltemos às próprias coisas! $\mathrm{E}$ isso em contraposição às construções desfeitas no ar e as descobertas casuais, em contraposição à aceitação de conceitos só aparentemente justificados e aos problemas aparentes que se impõem de uma geração à outra como verdadeiros problemas (HEIDEGGER, 2004, p.176).

O autor aponta que "a fenomenologia não é ciência de fatos, e sim ciência de essências", para isso, diante da ciência qualquer pesquisador deve se apresentar em atitude de espectador desinteressado, libertar-se das opiniões preconcebidas e, sem se deixar envolver pela banalidade e pelo óbvio, saber "ver", intuir, e descrever aquele universal que "um fato é aquilo e não outra coisa" (REALE, 2005). A fenomenologia pretende ser: "ciência fundamentada estavelmente, voltada à análise 
e à descrição das essências"," onde o conhecimento destas não é imediato, e sim obtido por meio da abstração ou comparação de inúmeros fatos. Inicialmente, a obra de Maurice Merleau-Ponty, especialmente nos seus textos ligados à percepção e à obra de arte, ele resume com clareza a tarefa da fenomenologia:

A fenomenologia é o estudo das essências, e todos os problemas,
segundo ela, resumem-se em definir essências: a essência da
percepção, a essência da consciência, por exemplo. Mas a
fenomenologia é também uma filosofia que repõe as essências na
existência, e não pensa que se possa compreender o homem e o
mundo de outra maneira senão a partir de sua 'facticidade'
(MERLEAU-PONTY, 1999, p.1).

Conforme Carsalade (2007), "para se comparar vários fatos, é preciso já ter captado uma essência, isto é, um aspecto pelo qual eles são semelhantes". Para o autor, a fenomenologia se propõe, portanto, a ser ciência das essências, e não de dados e fatos. Por isso, deve-se distinguir o aparecer de um objeto do objeto que aparece. Dessa forma, acredita-se ser possível compreender o universo rural em sua condição de bem cultural, visando a sua preservação, obtendo o conhecimento de sua essência, distinguindo o aparecer da paisagem rural, da paisagem rural que aparece. Assim, perceber o objeto como fenômeno, respeitando o bem cultural como único. Apesar do princípio de entendimento e análise adotado para o estudo de uma fazenda ser amplo e aplicável a qualquer fazenda, cada uma é única e aparece diferente das demais, mesmo ambas sendo fazendas.

\section{Sensibilidade Cultural para uma fazenda}

A partir da condição fenomenológica em que se manifesta o objeto, onde cada um se mostra como único, acredita-se somado a isso, a utilização do Analytic

\footnotetext{
${ }^{9}$ As essências são modos típicos do aparecer dos fenômenos [...]. Não abstraímos a ideia ou essência de "triângulo" da comparação de muitos triângulos: o que ocorre é que este, esse e aquele são triângulos porque são casos particulares da ideia de triângulo. Este triângulo isósceles desenhado no quadro negro existe aqui e agora, com estas dimensões e não outras. Esse é um dado de fato particular. Mas nele captamos uma essência. O desenho é de um triângulo e não de outra coisa (REALE, 2005, p.181).
} 
Hierarchy Process - AHP, que assim como é indicado para sistematizar demandas de decisões nos contextos econômicos, políticos, sociais e ambientais, possa ser igualmente utilizado como instrumento auxiliar nas análises e tomadas de decisão para a gestão da preservação de bens culturais, destacando-se a sensibilidade cultural de fazendas.

Em Chacaltana (2007), o AHP, método desenvolvido por Saaty em 1977, trata de uma metodologia de análise da paisagem pautada em princípios de auxílio à decisão por múltiplos critérios. Essa forma de análise apresenta importantes vantagens por colocar o "decisor a pensar na decisão de uma maneira lógica e verificar a inconsistência de seus julgamentos", reforçando assim a condição de se realizar uma redução fenomenológica da fazenda ou de seus componentes. O método proposto por Saaty (1977) possibilita análises de comparação de até 9 (nove) elementos simultaneamente. Tratam-se, portanto, de procedimentos multicritério, de apoio a decisão, e compreende as fases de justificativa e a fase de análise hierárquica. O AHP apresenta base numérica com capacidade para avaliar fatores qualitativos e quantitativos, sejam eles, tangíveis ou intangíveis. Nesse contexto, acredita-se que a maneira adequada de se estabelecer pesos para atividades de acordo com sua importância seja por meio da fenomenologia. O AHP:

\footnotetext{
propõe por intermédio da decisão do problema em níveis hierárquicos, determinar por meio da síntese dos valores dos agentes de decisão, uma medida global para cada alternativa, priorizando-as ou classificando-as ao finalizar o método (CHACALTANA, 2007).
}

Assim, a hierarquização monta um modelo da realidade e visualiza a interação dos componentes do sistema que possibilite confiança e flexibilidade. $O$ Método Saaty AHP é frequentemente utilizado em estudos de Índice de Sensibilidade Ambiental (ISA) e Vulnerabilidade ambiental, tendo resultados adequados às demandas necessárias. Parâmetros como proximidade de ruas, de áreas urbanas, de aterros sanitários, de aquicultura são utilizados em trabalhos de vulnerabilidade de ação antrópica a determinados meios ambientes. Para Chacaltana (2007), o Analytic Hierarchy Process é uma metodologia "amplamente flexível e pode ser utilizada como uma ferramenta de uso multidisciplinar".

Nessa pesquisa sobre estudos do patrimônio rural, utiliza-se o Método Saaty para traçar sensibilidade cultural da fazenda Fortaleza, localizada no sul do Espírito 
Santo, tendo a morfologia e as relações do ambiente construído como parâmetros. Para aplicação do AHP na fazenda Fortaleza, em sua condição cultural, buscou-se percebê-la despida de preconceitos, observando-a como fenômeno que se manifesta em sua essência, conforme esclarece Reale (2005), por meio da fenomenologia. Desse modo, percebe-se morfologicamente a Casa Sede, o ambiente construído, os caminhos, os rios e lagos, a floresta e as atividades agropastoris como importantes elementos ou componentes da paisagem rural e cultural da fazenda Fortaleza, relacionados para a obtenção da Sensibilidade Cultural no Ambiente Rural da Fazenda Fortaleza.

\section{Fatores de fragilidade morfológica e cultural}

Para obtenção da Sensibilidade Cultural, é necessário identificar fatores definidos e delimitados como relevantes à permanência da fazenda em seu contexto autêntico, visando a sua adequada preservação, destacando-se aqueles que se apresentam como essenciais. Considera-se neste caso, que a eliminação dos mesmos comprometeria a fazenda como unidade. A partir de uma base cartográfica oriunda do satélite GeoEye de 2009, e de visitas a campo para análise e percepção do ambiente rural, foi possível visualizar e delimitar, com o auxílio da fenomenologia e do aplicativo ArcGis 10.0, os elementos que demonstram fragilidade morfológica no contexto atual da fazenda Fortaleza e os limites da área de estudo para este universo rural de pesquisa. Os fatores morfológicos de fragilidade cultural no ambiente rural foram fotointerpretados diretamente na tela do computador, tomandose com base a imagem do satélite GeoEye de 2009. Os seis fatores fotointerpretados foram: 1. Casa Sede, 2. Ambiente Construído, 3. Caminhos, 4. Corpos d'água, 5. Atividades agropastoris e 6. Floresta.

A técnica aqui empregada tem por principal finalidade gerar dados adequados ao SIG, pois se acredita que a subjetividade das questões relativas à preservação do patrimônio cultural seja contemplada considerando os princípios da 
fenomenologia. Assim, a generalização de conceitos e polígonos em setores, por exemplo, pode ser entendida como uma etapa essencial de todo o processo, pois permite ao pesquisador um reconhecimento global e preliminar das fragilidades a que está exposta a fazenda. Portanto, os procedimentos seguintes são apenas uma consequência da compreensão da essência do bem cultural e sua apresentação geométrica no espaço definidor do meio ambiente em si. Acredita-se que seja possível deixar-se penetrar em um bem cultural e no processo que o produziu, examinando-o em sua plenitude formal, buscando, por assim dizer, sua realidade ontológica $^{10}$.

Para realização da Sensibilidade Cultural, eleita a fazenda Fortaleza, identificou-se a Casa Sede, e a partir dela adotou-se como limites de estudo a área determinada por meio de 500 metros em linha reta dos extremos do telhado da Casa Sede, de onde:

- Considerou-se o ambiente construído na área de estudo, destacando a Casa Sede;

- Relacionou-se a presença dos caminhos como definidores do espaço;

- Evidenciaram-se os corpos d'água, compostos basicamente por rios e lagos;

- Relacionaram-se os espaços das atividades agropastoris;

- Considerou-se a presença de fragmentos de florestas.

\footnotetext{
${ }^{10}$ Ontologia (em grego ontos e logoi, "conhecimento do ser") é a parte da filosofia que trata da natureza do ser, da realidade, da existência dos entes e das questões metafísicas em geral. A ontologia trata do ser enquanto ser, isto é, do ser concebido como tendo uma natureza comum que é inerente a todos e a cada um dos seres. Costuma ser confundida com metafísica. Conquanto tenham certa comunhão ou interseção em objeto de estudo, nenhuma das duas áreas é subconjunto lógico da outra, ainda que na identidade (HOUAISS, 2009).
} 


\section{Identificação dos fatores que demonstraram fragilidade morfológica e cultural para uma fazenda: o caso da fazenda Fortaleza}

Para mapeamento da Sensibilidade Cultural da fazenda Fortaleza foram identificados os seguintes fatores que demonstram fragilidade morfológica e cultural:

\section{Casa Sede}

$\mathrm{Na}$ identificação da Casa Sede como Fator de Fragilidade Morfológica e Cultural - FFMC (Figura 38), levou-se em consideração que o seu maior impacto cultural está relacionado com a própria existência, onde a delicadeza de sua condição morfológica é máxima, entendendo que sua eliminação no espaço existencial descarregaria significativamente o sentido cultural da fazenda em seu ambiente rural, enquanto objeto de interesse de preservação. Impactos sobre a edificação, ou transformação morfológica inadequados na Casa Sede, comprometeriam a percepção da fazenda enquanto bem cultural.

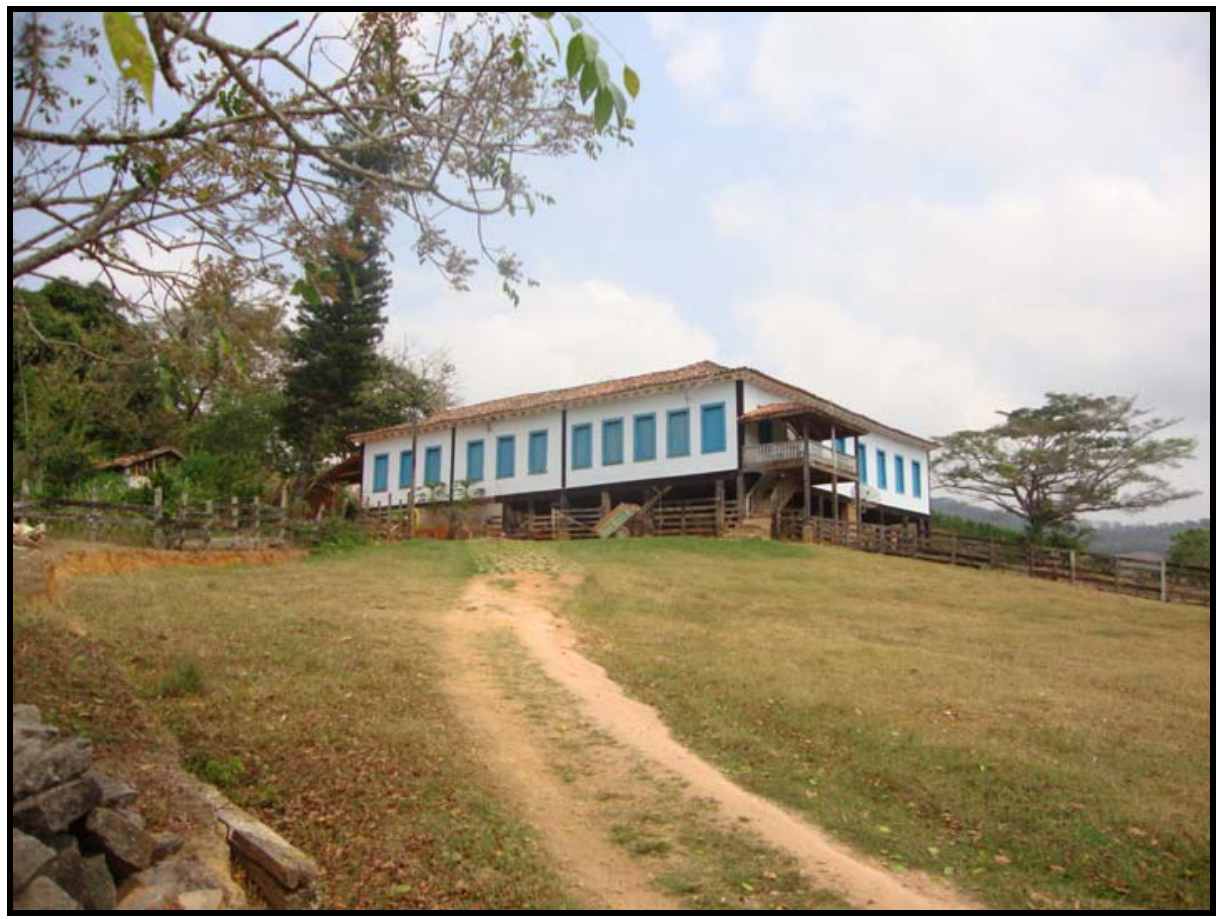

Figura 38. Casa Sede na área de estudo da fazenda Fortaleza. 
Ambiente Construído

Acredita-se que a partir de ações de interferência humana na paisagem, o ambiente construído agrupe construções de elementos e volumes arquitetônicos que de certa forma se mostram expressivos na constituição da fazenda Fortaleza, compondo assim, o ambiente natural e edificado, constante de infraestrutura rural para permanência das demandas que o espaço exige (Figura 39), tanto para aquelas agropastoris, quanto para outro fim. Considera-se que a eliminação ou ação nos elementos que compõem o ambiente construído fragilize a fazenda em sua totalidade, uma vez que os programas que a compõem são essenciais a sua integridade. Ressalta-se que a perda de moinhos, engenhos dentre outros, são danosos, mas não compromete o ambiente construído da fazenda entendendo-a em sua unidade potencial, conforme Brandi (2005).

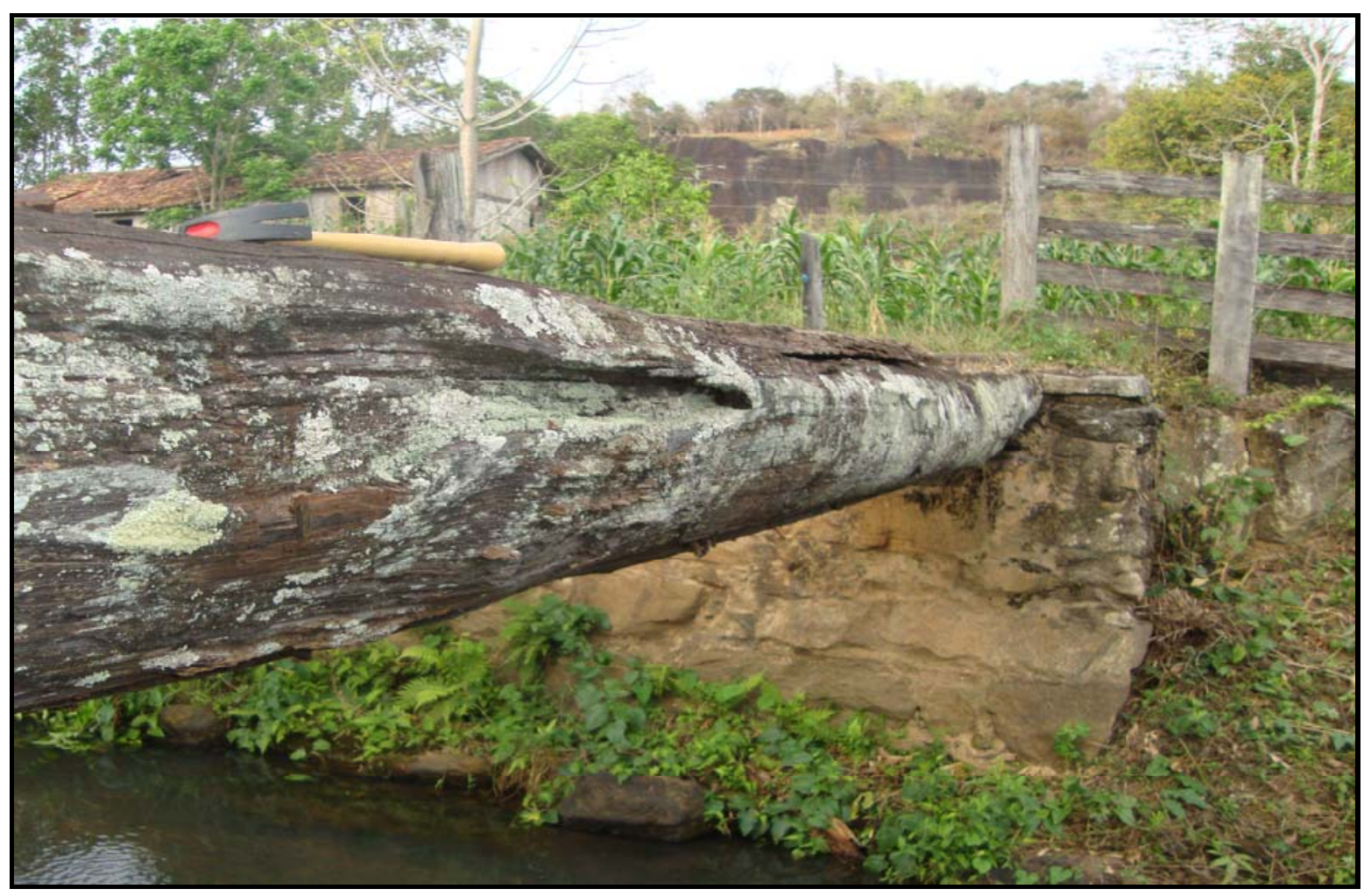

Figura 39. Ambiente construído na área de estudo da fazenda Fortaleza. 


\section{Caminhos}

Entende-se por vias de circulação caminhos e estradas, representados pelas vias rurais não pavimentadas, que são superfícies por onde transitam veículos, pessoas e animais, compreendendo a pista, e sua margem, podendo possuir ou não interseções em nível, além de coletar e distribuir o trânsito local. As vias de circulação tradicionalmente representam importantes elementos de valoração e constituição dos espaços habitados pelo homem. Para o universo rural, é fundamental a existência de caminhos para a sobrevivência de uma fazenda, seja na condição de fluxo de insumos e mercadorias, seja para a movimentação de pessoas e animais. Os caminhos se constituem elementos indispensáveis à instalação e manutenção do ambiente rural. Em se tratando de demandas de preservação de bens culturais, torna-se difícil imaginar a manutenção e permanência de um objeto que esteja inacessível. Para a fazenda Fortaleza, ao se apresentar na condição de objeto único em sua totalidade, se mantêm, ou seja, ela existe sem os caminhos, entretanto, eles constituem fatores de sustentabilidade do ambiente construído em seu meio físico, na busca pela manutenção da paisagem ao qual compõe e define (Figura 40).

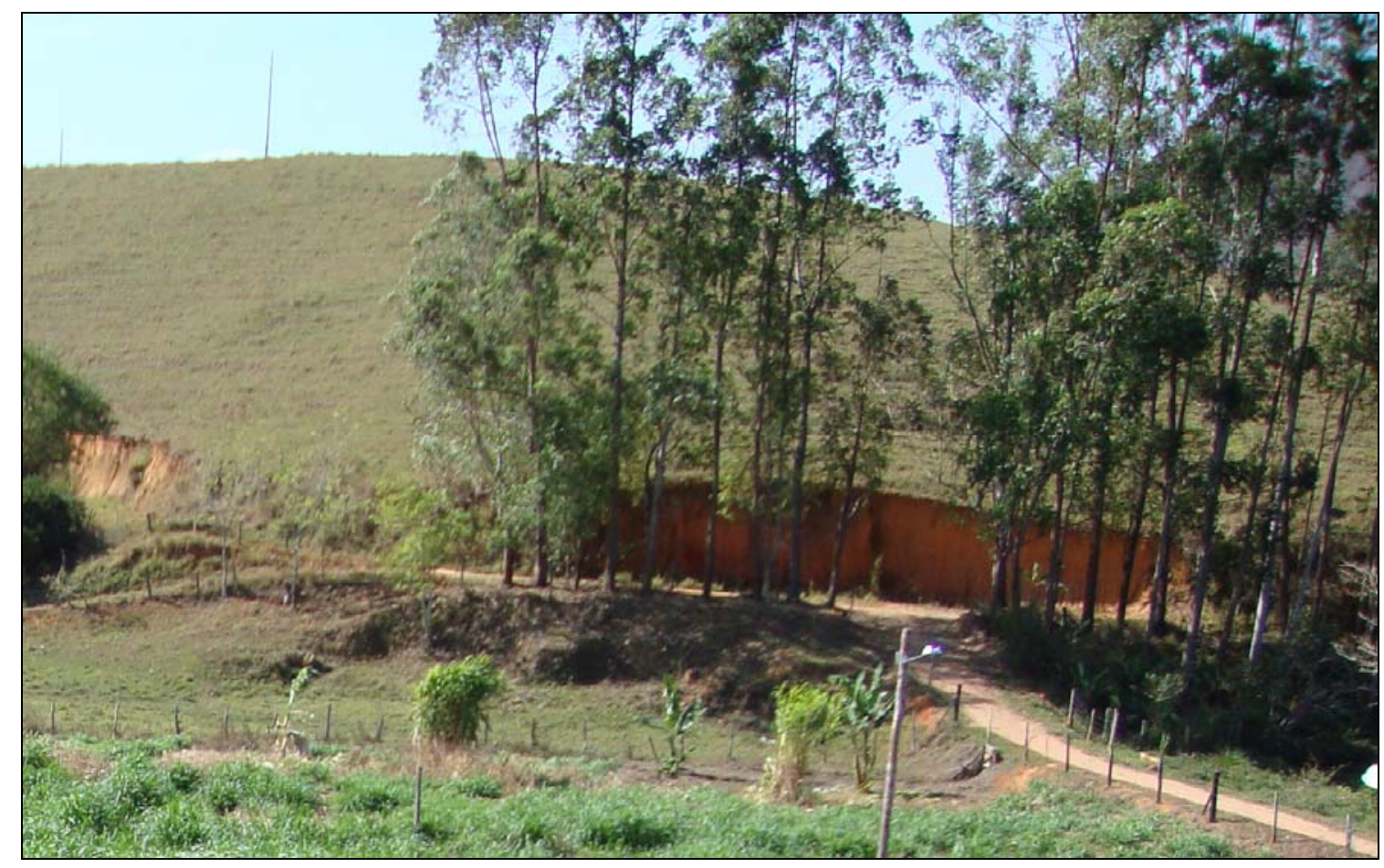

Figura 40. Caminhos na área de estudo da fazenda Fortaleza. 


\section{Corpos d'água}

Entende-se por corpos d'água a acumulação de água sobre a terra. Referemse geralmente a expressivos volumes de água, mas é usado também para lagoas, poças ou zona úmidas. Para efeito de estudo na fazenda Fortaleza, os cursos d'água, como córregos e rios, serão considerados corpos d'água (Figura 41). Foi considerado ainda nesse conceito as outras formações geográficas em que a água se move de um local para outro. Alguns corpos d'água podem ser feitos pelo homem, são artificiais, como os reservatórios. A presença de boa água representa elemento de permanência ao longo dos tempos no que se refere à escolha do melhor local para instalação de uma fazenda. Ao se apresentar na condição de objeto de preservação cultural, uma fazenda se coloca em condição de maior favorecimento à sustentabilidade se os corpos d'água estiverem presentes em seu meio ambiente e se forem mantidos adequadamente. Na atualidade, a água representa elemento de destacada preciosidade, e no ambiente rural se mostra como fator de relevância para a manutenção de uma fazenda. Entretanto para a fazenda Fortaleza, enquanto bem cultural, visando a sua permanência às gerações futuras, acredita-se que sua eliminação não destruiria a fazenda em sua unidade potencial.

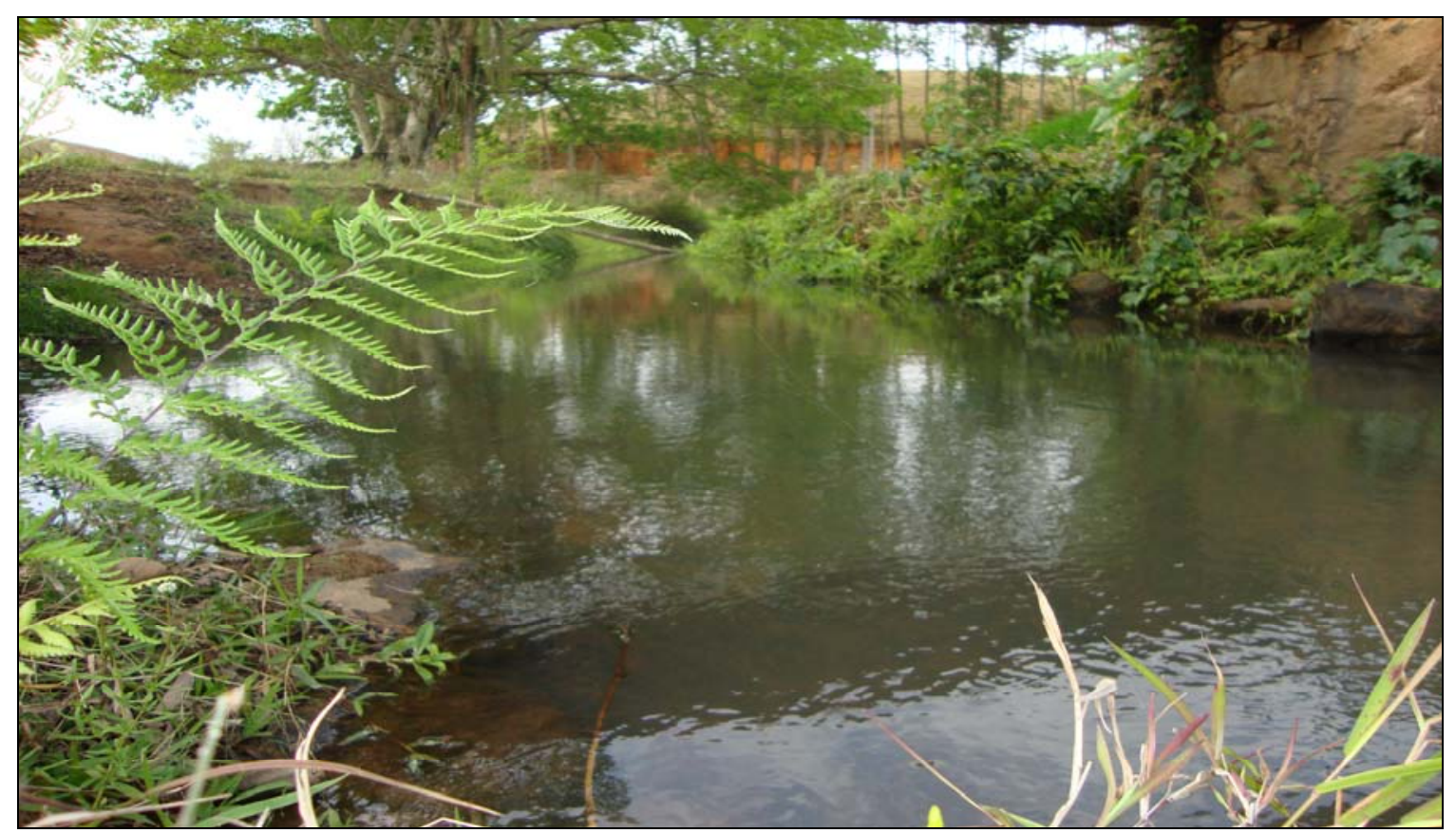

Figura 41. Corpos d'água na área de estudo da fazenda Fortaleza. 


\section{Atividades agropastoris}

Para uma fazenda, tradicionalmente, plantar e criar animais representa pioneiramente parâmetro essencial à sua instalação (Figura 42). Para a fazenda Fortaleza, as atividades agropastoris são de relevância à manutenção da propriedade, mas para sua condição de bem cultural, os componentes morfológicos relativos ao ambiente construído se manifestam com destacada relevância em relação ao uso que a constitui. O bem cultural, ao permanecer por décadas na condição de objeto edificado no meio rural, transforma sua maneira de apropriação do espaço enquanto meio de sustentabilidade, sem, contudo eliminar sua existência na paisagem, mesmo que a transforme e modifique. Essa condição a que se apresenta o fenômeno das atividades agropastoris as coloca como fator relevante à permanência da fazenda, mas não como inalterados, uma vez que o uso é dinâmico e mutável.

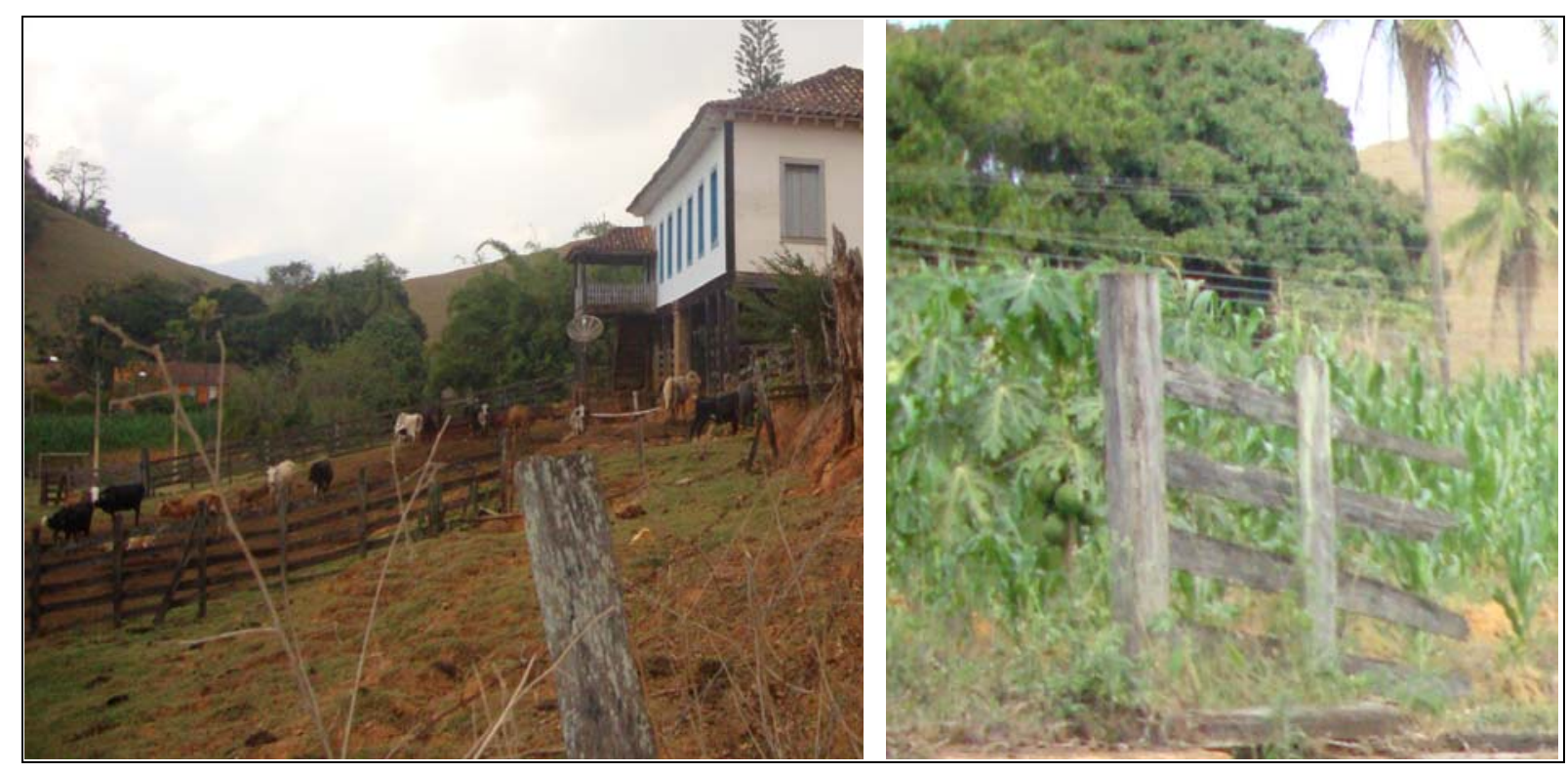

Figura 42. Atividades agropastoris na área de estudo da fazenda Fortaleza. 
Floresta

De acordo com a Organização das Nações Unidas para a Agricultura e Alimentação (FAO, 2012), Floresta é definida como área de maior que 0,5 ha com árvores que medem mais de $5 \mathrm{~m}$ (cinco metros) de altura e cobertura de copa superior a 10\%, ou ainda árvores capazes de alcançar estes parâmetros in situ. Isso não inclui terra que está predominantemente sob uso agrícola ou urbano. Entretanto, no Brasil, o Serviço Florestal Brasileiro, no desenvolvimento de seus trabalhos e na elaboração dos relatórios nacionais e internacionais sobre os recursos florestais do país, considera como floresta as tipologias de vegetação lenhosas que mais se aproximam da definição de florestas. Para o universo da fazenda Fortaleza, enquanto bem cultural a floresta é percebida como importante elemento que condicionou a ocupação do local e construção das edificações e elementos definidores do ambiente rural (Figura 43). Na atualidade, traz possibilidades de sustentabilidade ao espaço cujas terras são inadequadas ao cultivo. Apesar de representar possibilidade de valoração e sustentabilidade do bem cultural de caráter rural, a floresta não se coloca como indispensável para a permanência da fazenda às gerações futuras. Mas ao contrário disso, sua ampliação descontrolada eliminaria os aspectos agrários que traz a identidade da fazenda agropastoril em si.

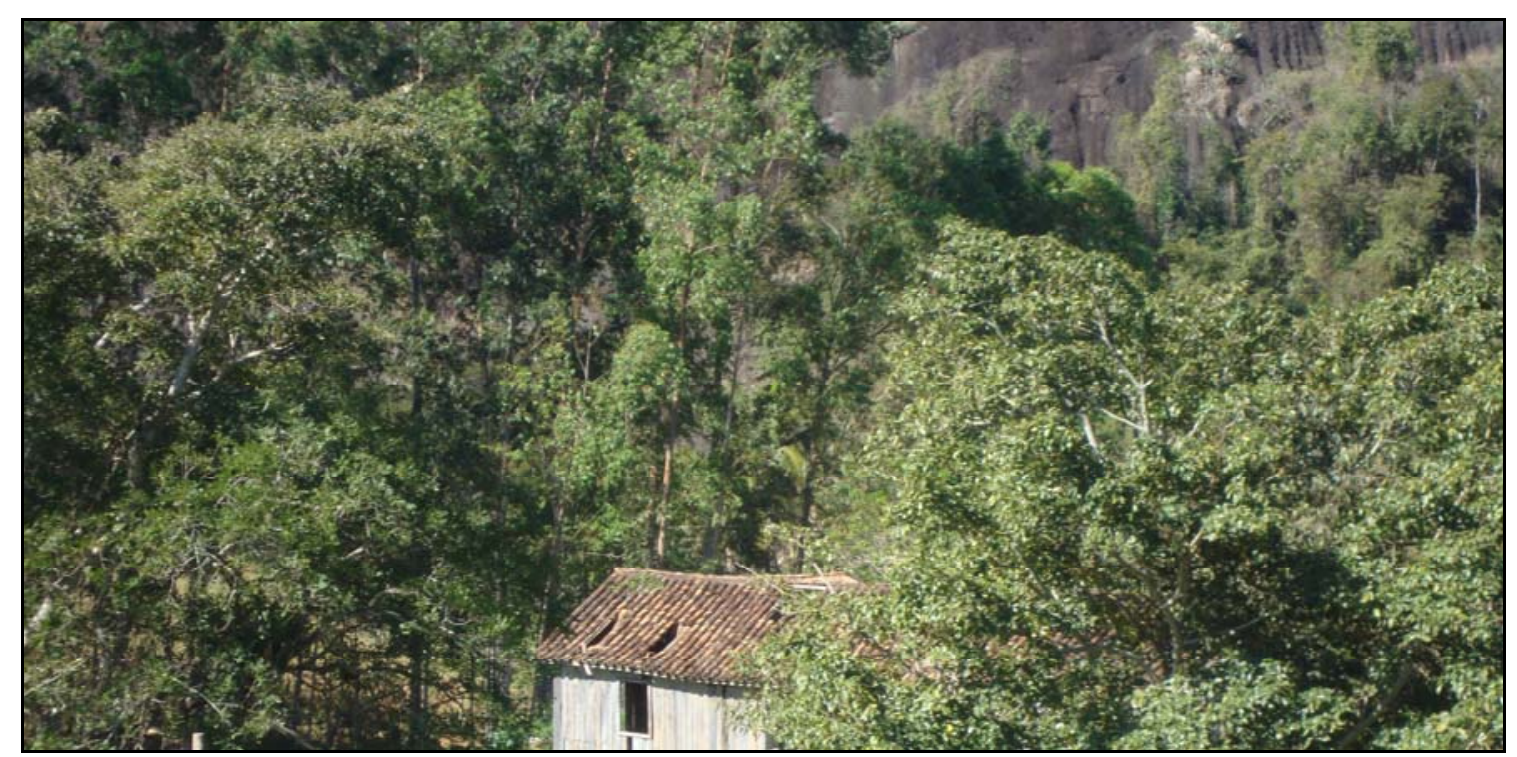

Figura 43. Floresta na área de estudo da fazenda Fortaleza. 


\section{Evolução da Sensibilidade cultural: procedimentos adotados para os anos de 1970 e 2009}

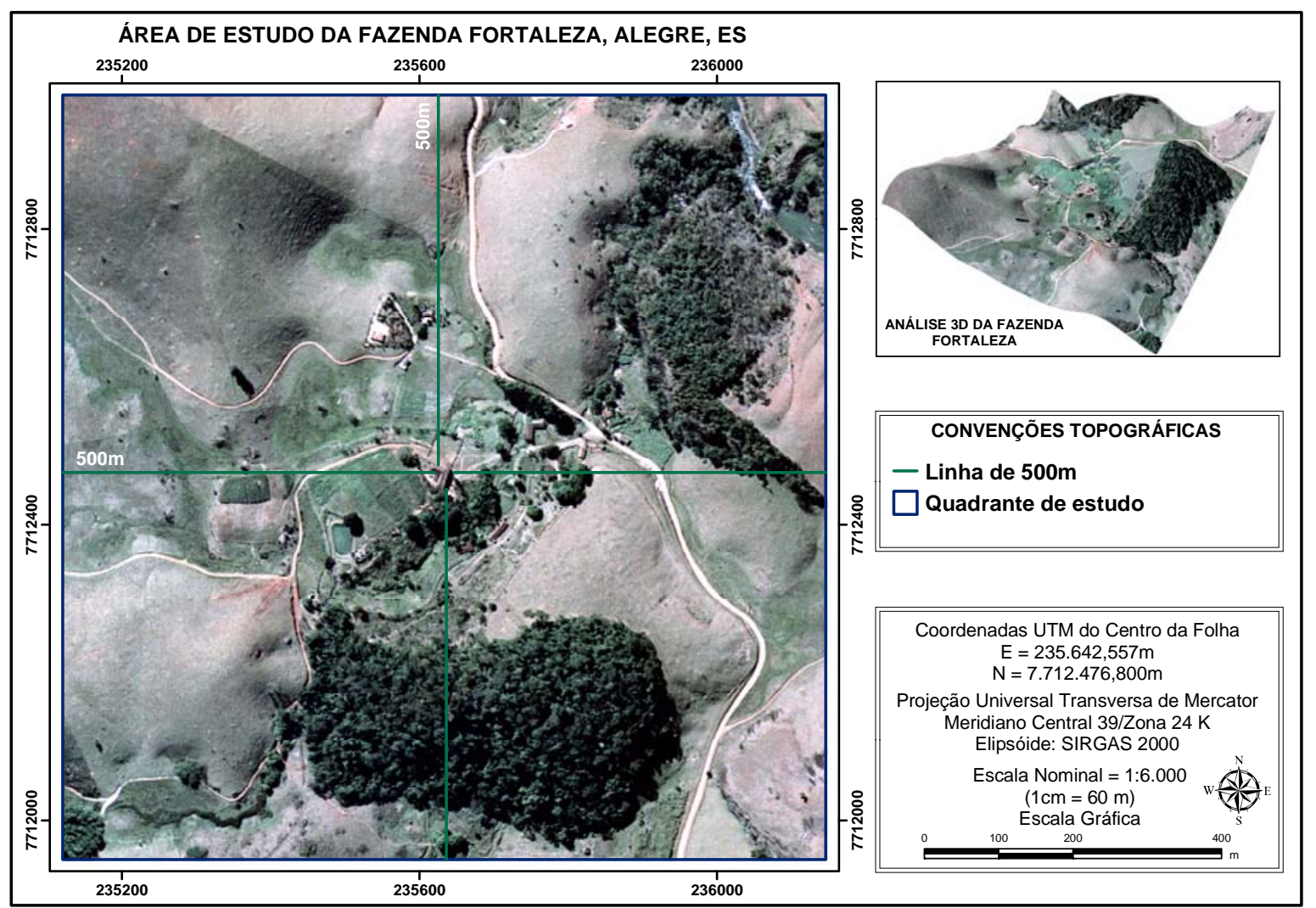

Figura 44. Área de estudo da fazenda Fortaleza, Alegre, ES.

Para o mapeamento da Sensibilidade Cultural para os Anos de 1970 e 2009 utilizou como referência a área de estudo da fazenda Fortaleza, definida pelos 500metros em linha reta a partir dos extremos dos beirais da casa sede, conforme figura 44. O mapeamento constou dos seguintes procedimentos:

ETAPA 01: Fotointepretação dos Fatores de Fragilidade Morfológica Cultural do ambiente rural - FFMC

Para os estudos de sensibilidade cultural da fazenda Fortaleza, considerou-se adequada a junção de classes de uso da terra definidas pelo IBGE (2006). Observando que na condição de bem cultural, e respeitando a manifestação da fragilidade física da fazenda em relação à sua permanência, conforme o fenômeno manifesta-se à consciência de quem o percebe, a partir da ciência das essências, da 
fenomenologia, com o intuito de descrever efetivamente o que se manifesta à consciência, o que nela se traduz e nos limites em que se apresenta, considera-se que rios e lagos sejam entendidos como um único fator denominado corpos d'água e edificação e instalações rurais se juntem em um ambiente construído como fatores morfológicos do ambiente a que estão inseridos.

Nessa organização, a Casa Sede se coloca em isolado, tendo em vista ser um elemento de destaque na composição da unidade potencial do ambiente rural como bem cultural. Seguindo essa mesma configuração de leitura espacial, pastagem e área agriculturada se agrupam como atividades agropastoris. Já estrada não pavimentada, se amplia para o conceito de vias de circulação por agregar caminhos de caráter local, atribuídos à locomoção de pedestres e animais, conforme os polígonos representativos de cada Fator de Fragilidade Morfológica e Cultural FFMC do ambiente rural, fotointerpretados em tela, conforme mostrados nas Figuras 45 e 46, para os anos de 1970 e 2009 , respectivamente.

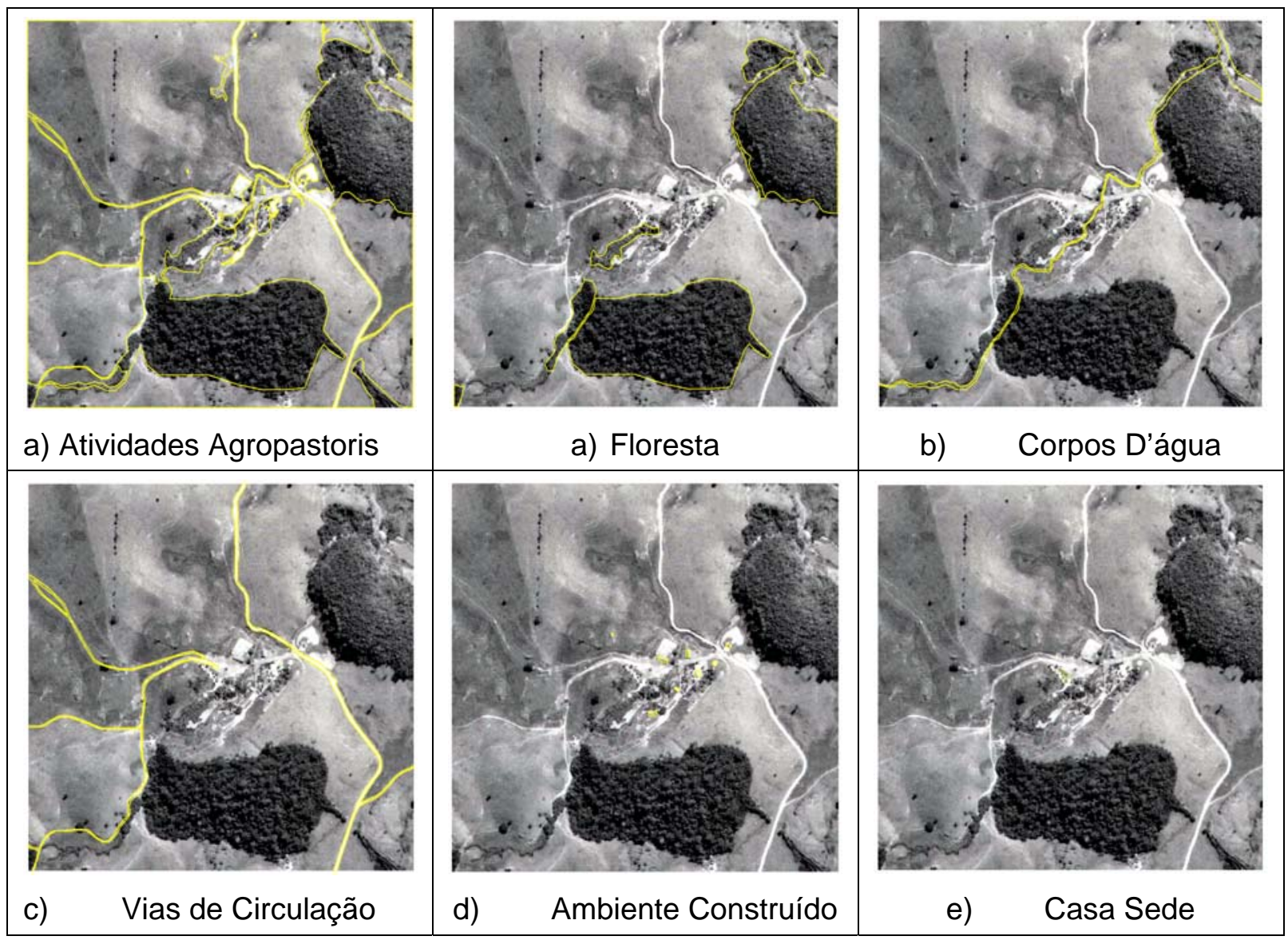

Figura 45. Fatores de Fragilidade Morfológica e Cultural da fazenda Fortaleza para 1970. 


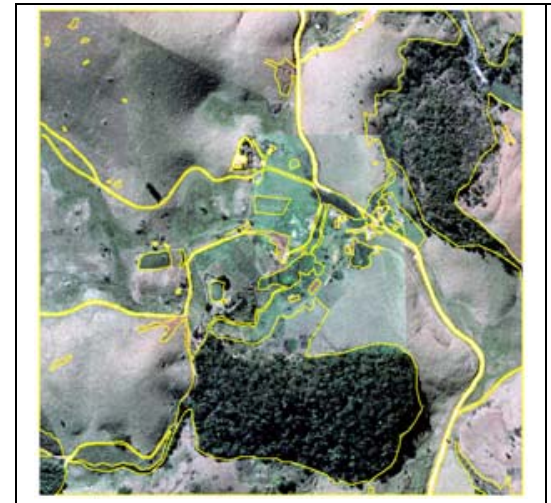

a) Atividades Agropastoris

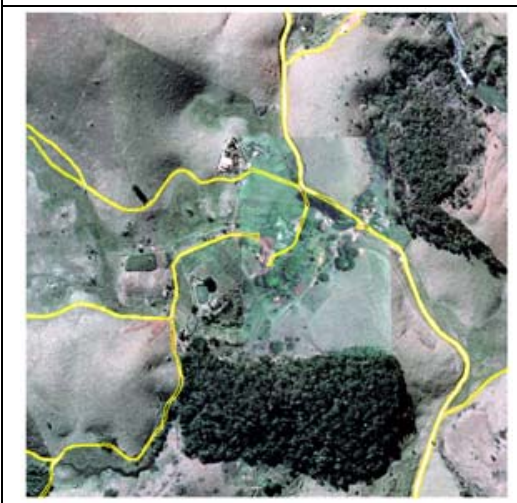

c) Vias de Circulação

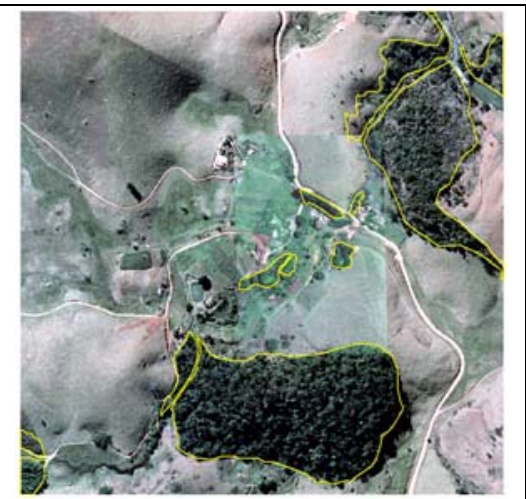

a) Floresta

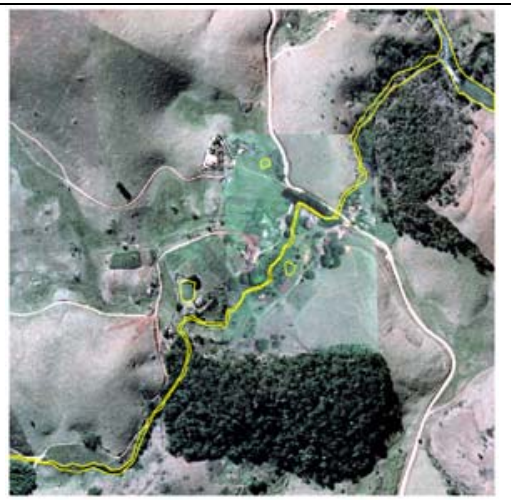

b) Corpos D'água

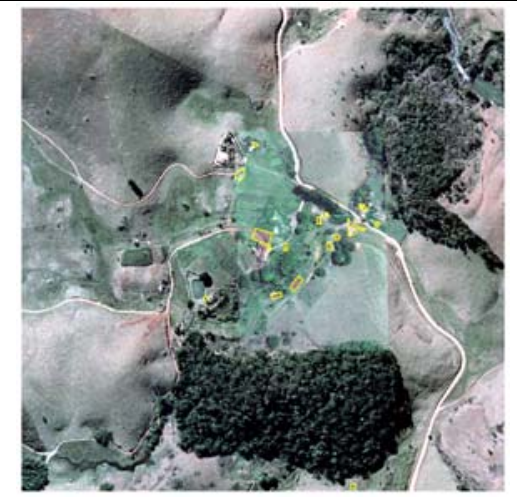

d) Ambiente Construído

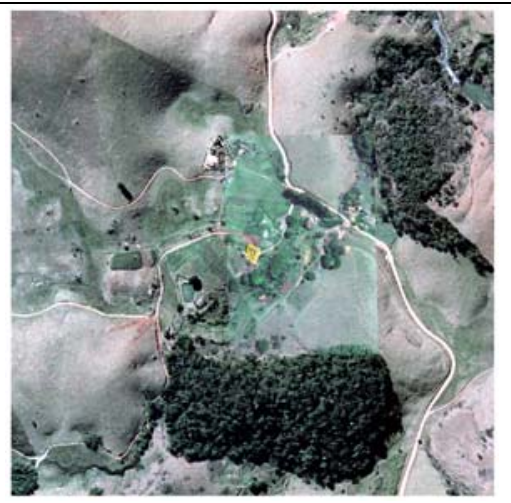

e) Casa Sede

Figura 46. Fatores de Fragilidade Morfológica e Cultural da fazenda Fortaleza para 2009.

ETAPA 02: Espacialização da distância linear em linha reta

Uma superfície de distância em linha reta é usada para encontrar a distância mais próxima, uma linha reta, a partir de cada célula para a origem mais próxima. Observe na Figura 47, que após a geração da imagem matricial de distância em linha reta (Distance Straight Line), os valores de distância dos pixels $D_{42}$ e $D_{33}$, são de 14,1 e 28,3, respectivamente (SANTOS et al, 2010).

Após levantamento e mapeamento dos Fatores de Fragilidade Morfológica e Cultural - FFMC para a fazenda Fortaleza iniciou-se no ArcGis 10.0 a representação das informações geográficas e da paisagem do ambiente rural de forma a gerar mapas que representem as distâncias dos fatores de fragilidade morfológica e cultural apresentados. Essa distância é obtida relacionando-se cada fator 
isoladamente e posteriormente todos entre si, a partir de sua condição existencial em relação ao universo rural como bem cultural.

Para representar a distância de um determinado fator em condição de fragilidade, gerou-se um mapa de distância linear que é uma imagem matricial formada por pixels, representada pela menor unidade exibida pela imagem, que registra uma distância linear " $X$ " em metros, com origem no ponto zero, ou seja, o fator na condição de máxima fragilidade em si, até o valor "n" em metros, representando a distância extrema alcançada pelo mapa e levando em consideração os limites da imagem gerada, restrita pela definição da área de estudo elegível (SANTOS, et al, 2010).

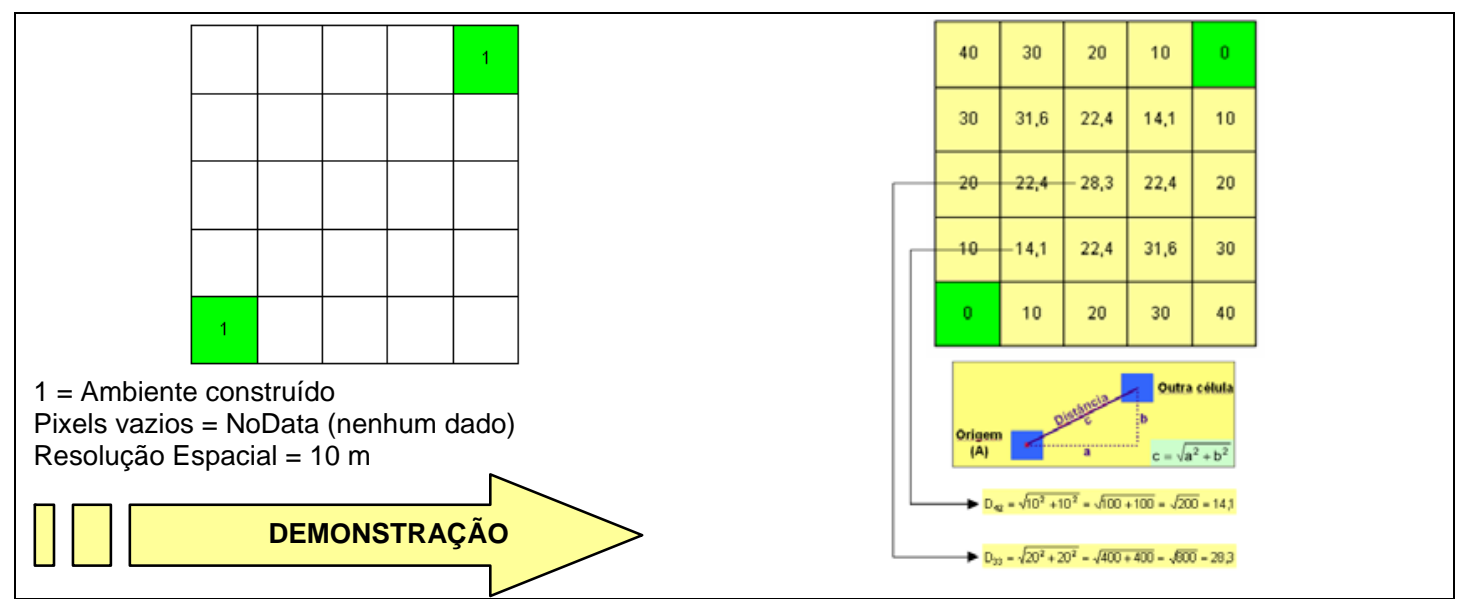

Figura 47. Exemplo prático de uma imagem matricial de distância em linha reta, (SANTOS et al, 2010).

Para cada parâmetro de fragilidade morfológica e cultural, diante do ambiente rural, foi gerado um mapa de distância em linha reta, mostrados nas Figuras 48 e 49, para os anos de 1970 e 2009, respectivamente. 


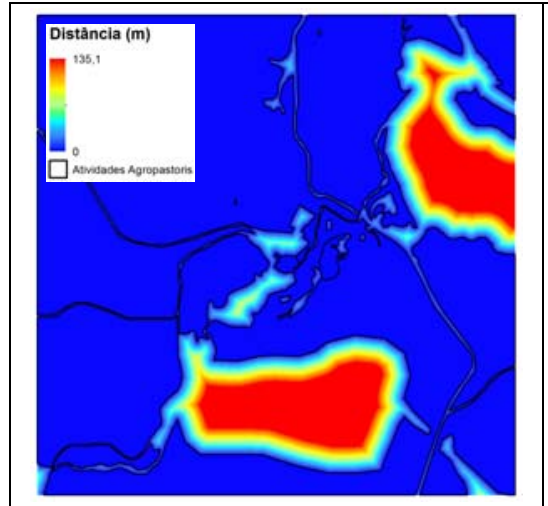

a) Atividades Agro-Pastoris

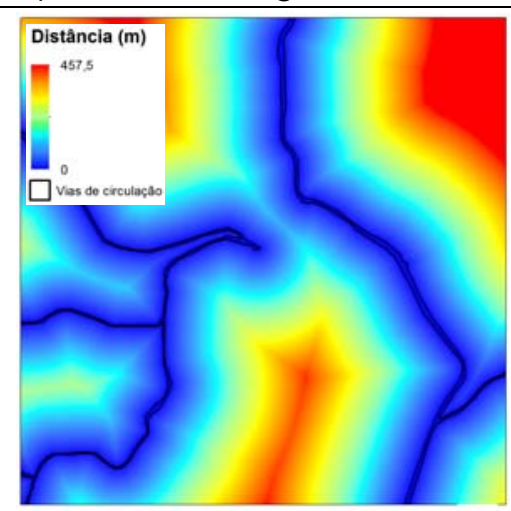

c) Vias de Circulação

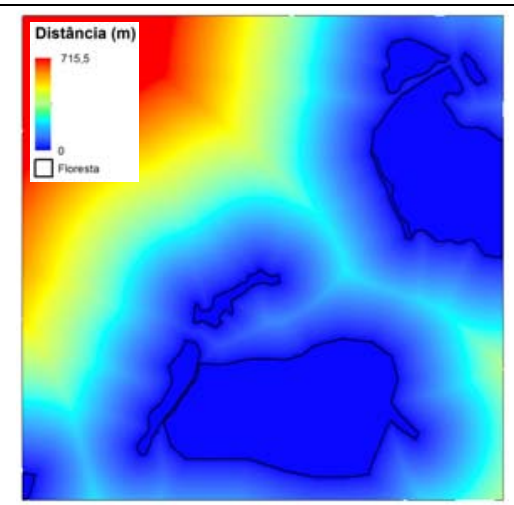

a) Floresta

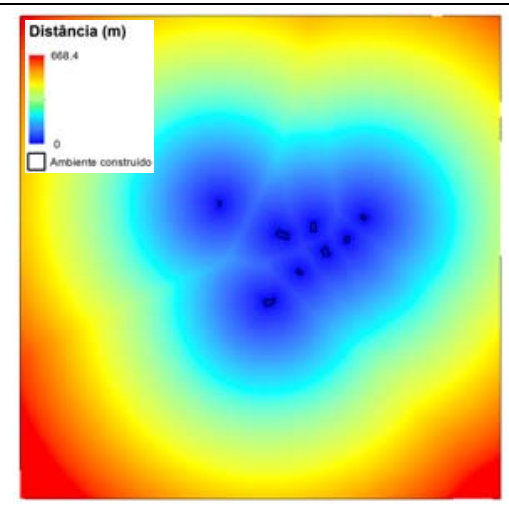

d) Ambiente Construído

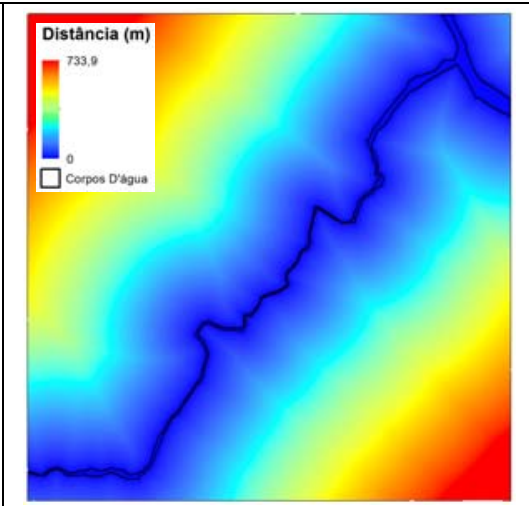

b) Corpos D'água

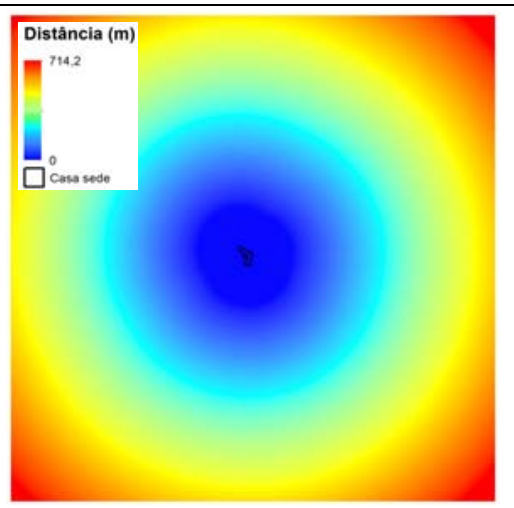

e) Casa Sede

Figura 48. Distância em linha reta de cada FFMC da fazenda Fortaleza para o ano de 1970.

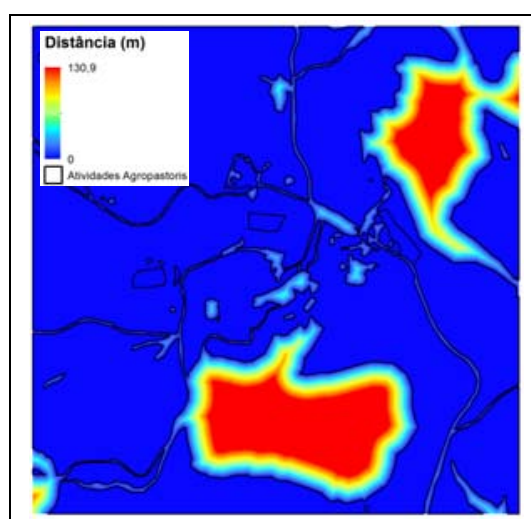

a) Atividades Agro-Pastoris

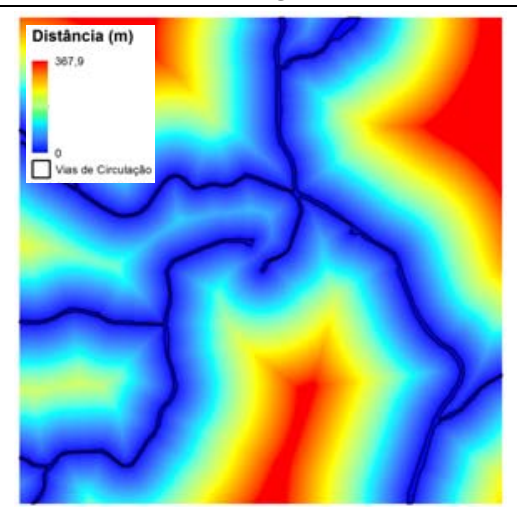

c) Vias de Circulação

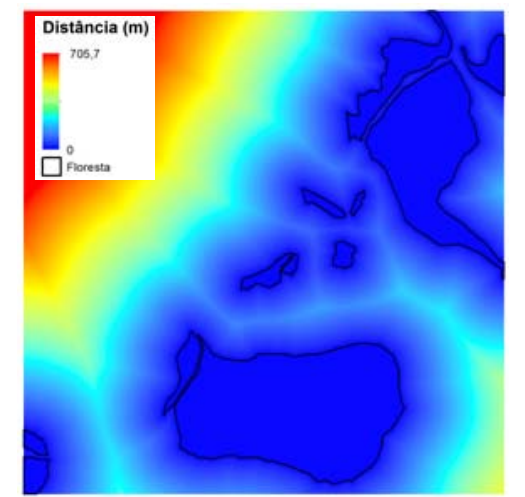

a) Floresta

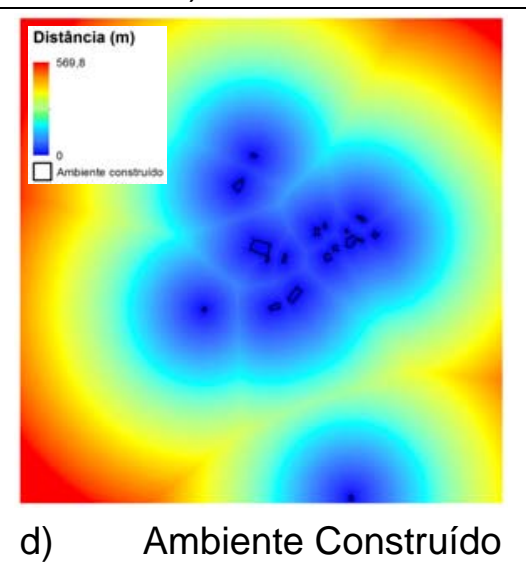

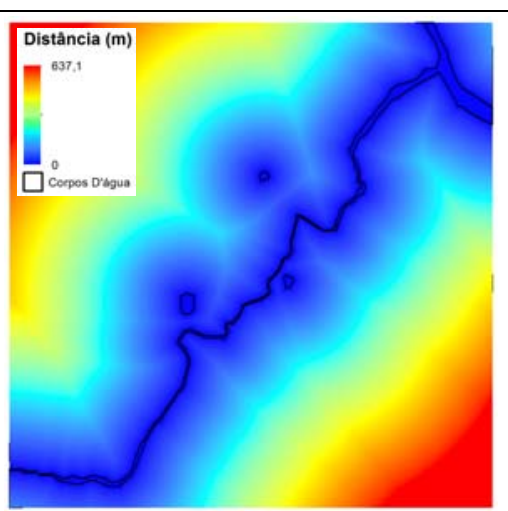

b) Corpos D'água

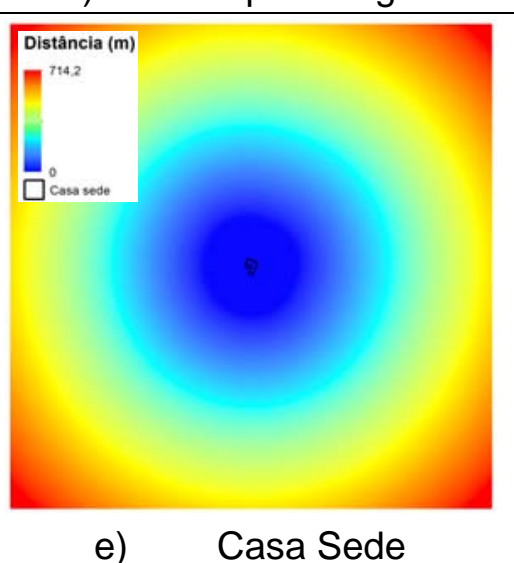

Figura 49. Distância em linha reta de cada FFMC da fazenda Fortaleza para o ano de 2009. 
ETAPA 03: Padronização fuzzy dos mapas de distância linear em linha reta.

A padronização da distância em linha reta considera que os Fatores de Fragilidade Morfológica e Cultural estão em diversas localizações dentro da área de estudo e mesmo assim, é necessária a classificação dessa linha reta em uma mesma escala de valores para fins de comparação. São gerados novos mapas de distâncias da área, considerando que terão valores comuns em unidade de medida sem perder sua localização absoluta. A Figura 50 demonstra a relação existente entre a padronização dos Fatores de Fragilidade Morfológica e Cultural do ambiente rural, onde o ponto "C" equivale ao menor valor de distância encontrado entre todos os mapas de distância gerados, e o ponto "D", o maior valor respectivamente.

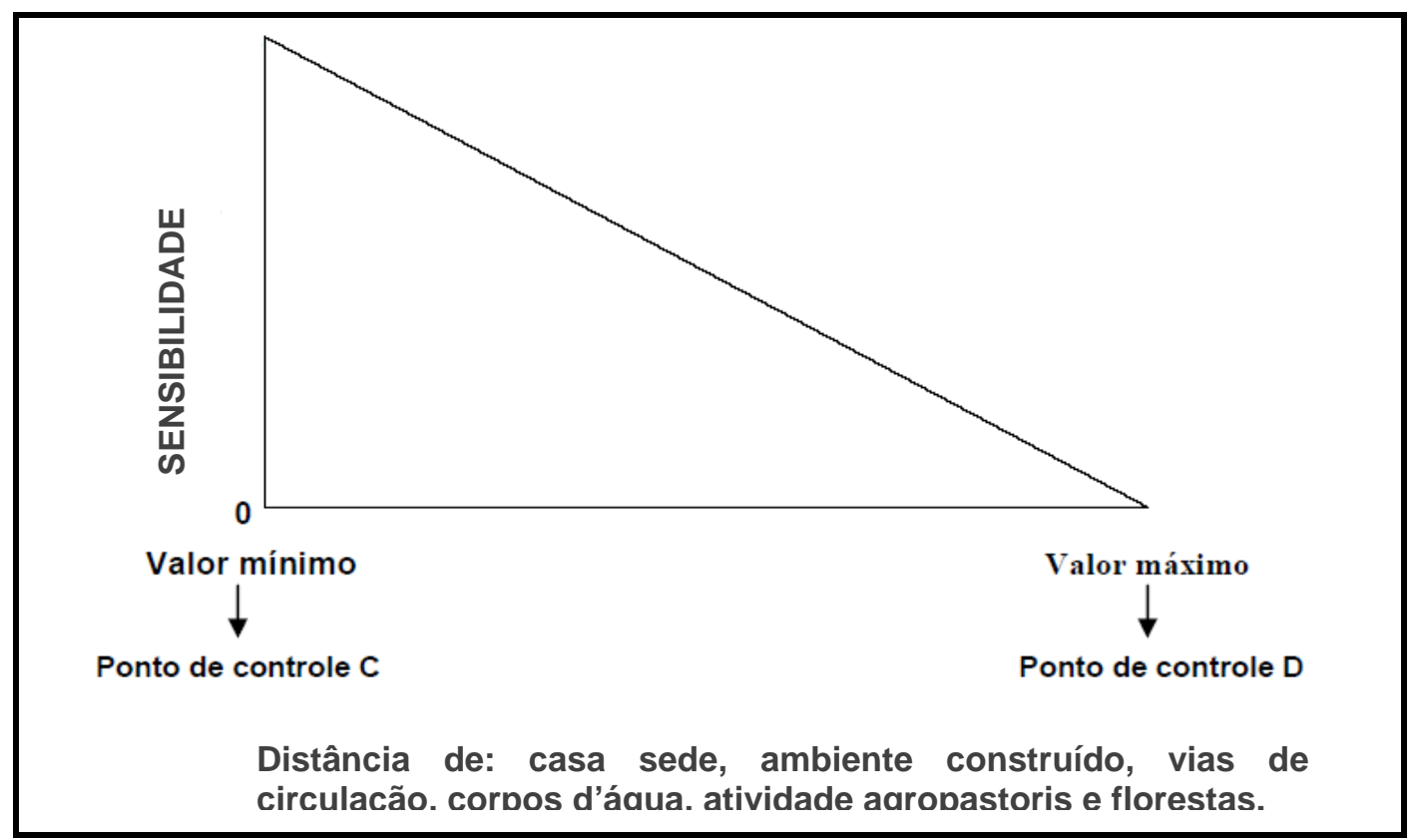

Figura 50. Função de reescalonamento linear decrescente, Adap. de ROSOT et al (2000).

Para a padronização, optou-se por usar o comando FUZZY, que permite o reescalonamento das medidas para uma escala linear decrescente que varia de $0 \mathrm{a}$ 1, sendo que há uma entrada com o menor e o maior valor do mapa de distância em linha reta. Com a padronização FUZZY, cada fator tem sua maior distância atribuída ao valor 1, equivalente a $100 \%$, e sua distância zero, continua no ponto de origem zero. A padronização Fuzzy dos mapas de distância linear em linha reta para os anos de 1970 e 2009 dos Fatores de Fragilidade Morfológica e Cultural é mostrada nas Figuras 51 e 52, respectivamente. 


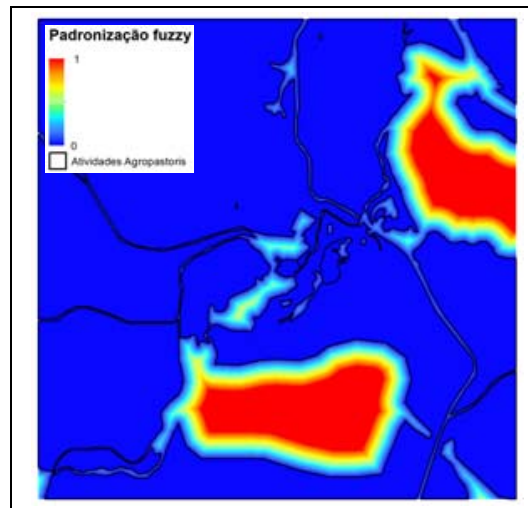

a) Atividades Agro-Pastoris

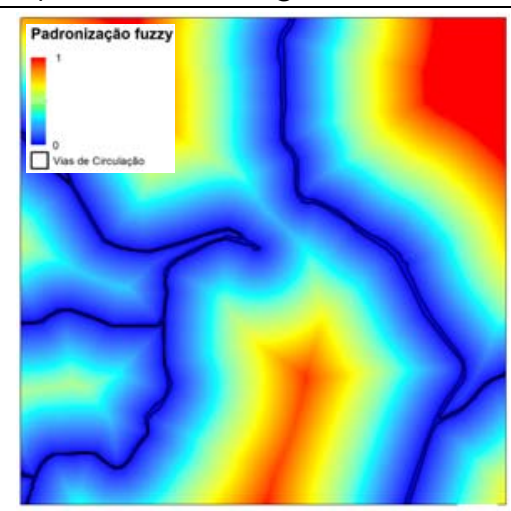

c) Vias de Circulação

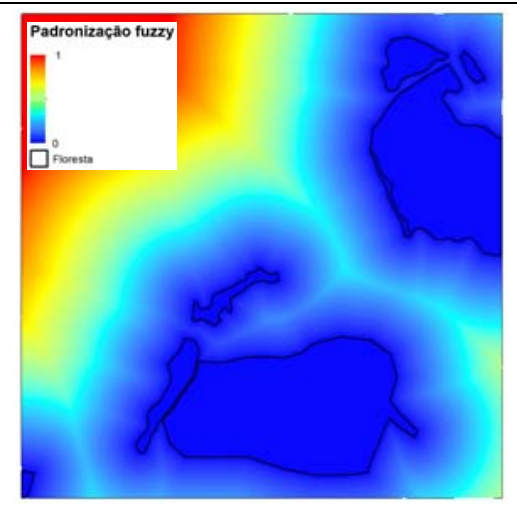

a) Floresta

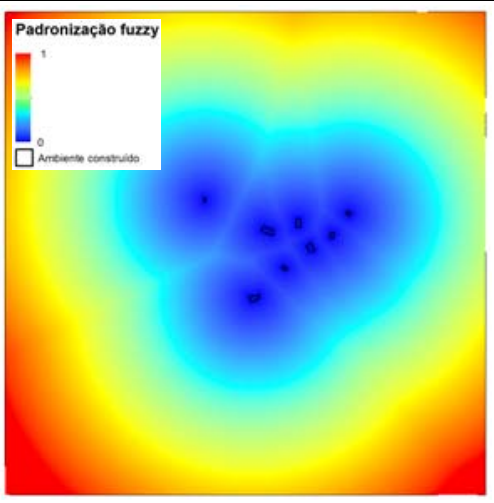

d) Ambiente Construído

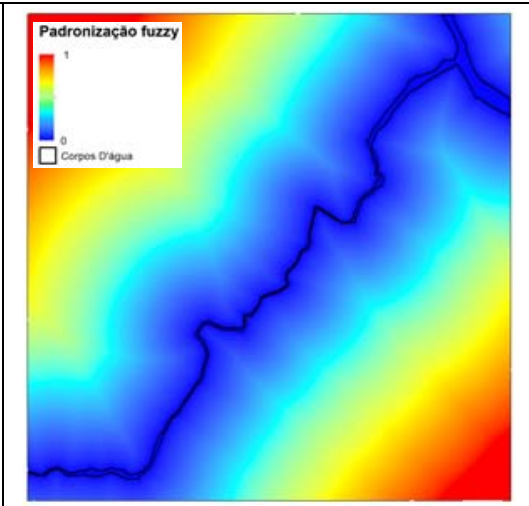

b) Corpos D'água

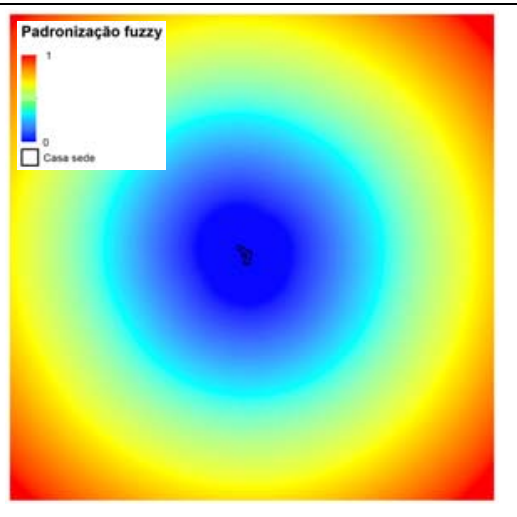

e) Casa Sede

Figura 51. Padronização Fuzzy da distancia em linha reta - FFMC para 1970, fazenda Fortaleza.

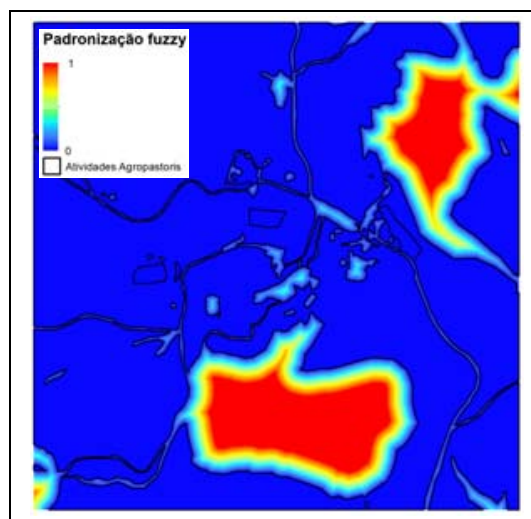

a) Atividades Agropastoris

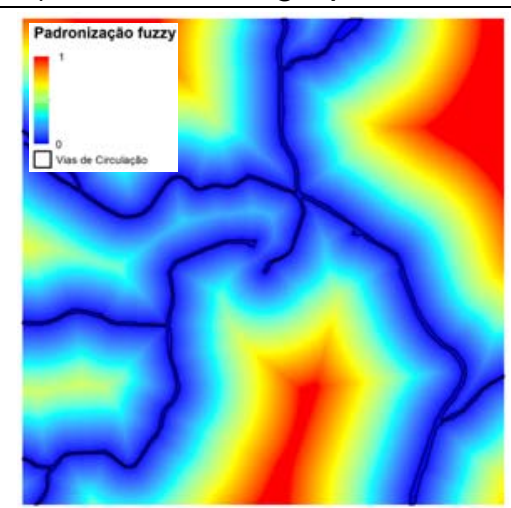

c) Vias de Circulação

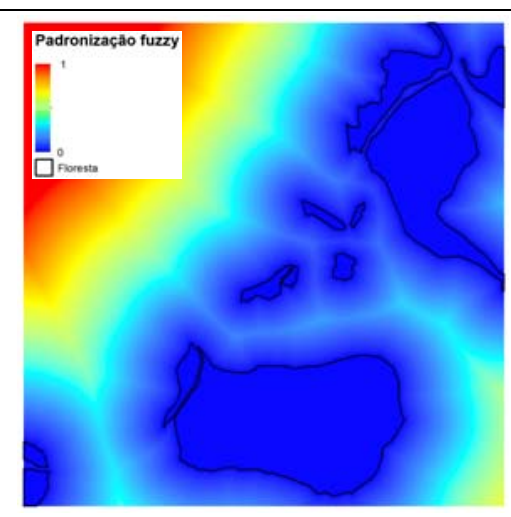

a) Floresta

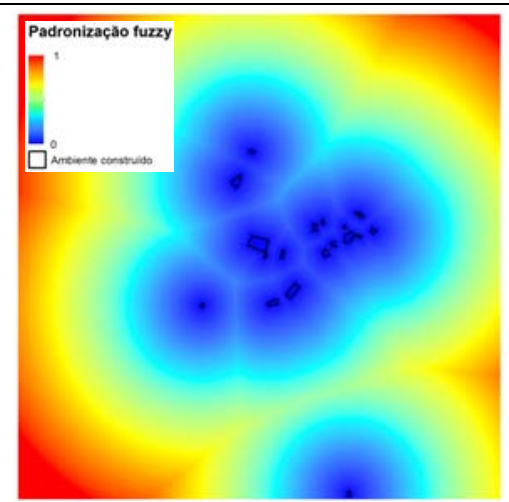

d) Ambiente Construído

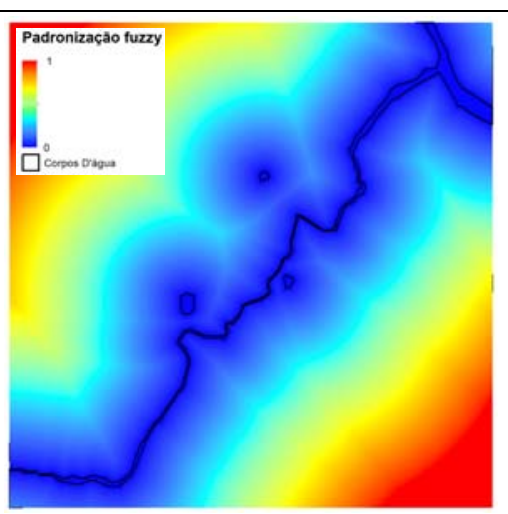

b) Corpos D'água

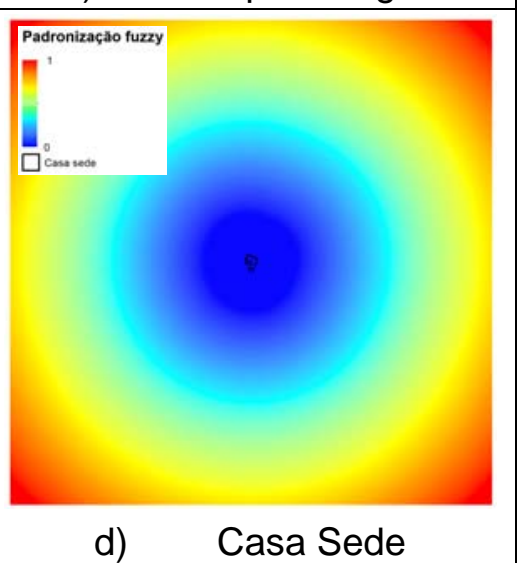

Figura 52. Padronização Fuzzy da distância em linha reta - FFMC para 2009, fazenda Fortaleza. 
ETAPA 04: Modelo de Sensibilidade Cultural para o Ambiente Rural

Para a elaboração do Modelo de Sensibilidade Cultural para o Ambiente Rural (SCAR), referente aos anos de 1970 e 2009, visando representar de forma mais real as condições encontradas na área de estudo da fazenda Fortaleza, foi realizada a ponderação dos dados, conforme esclarecido anteriormente, utilizando o método AHP proposto por Saaty (1977), por meio da decisão de demandas em níveis hierárquicos. Esse método determina por meio da síntese dos valores dos agentes de decisão, uma medida global para cada alternativa possível, priorizandoas ou classificando-as ao finalizar o método (GOMES et al., 2004). É eleita a matriz de comparação par a par ou matriz de decisão, fazendo uso da escala fundamental de Saaty (1977), Tabela 4. Conforme Santos et al (2010), o método de elaboração da matriz faz uso de uma escala de comparação, em que se pode definir linearmente a hierarquia de importância entre os Fatores de Fragilidade Morfológica e Cultural para o ambiente rural, fazenda Fortaleza, assim identificados: Casa Sede, ambiente construído, vias de circulação, corpos d'água, floresta e atividades agro pastoris, obtidos a partir das reflexões fenomenológicas.

Tabela 4. Escala de comparadores Saaty (1977

\begin{tabular}{cl}
\hline VALORES & \multicolumn{1}{c}{ IMPORTÂNCIA MÚTUA } \\
\hline $1 / 9$ & Extremamente menos importante que \\
$1 / 7$ & Muito fortemente menos importante que \\
$1 / 5$ & Fortemente menos importante que \\
$1 / 3$ & Moderadamente menos importante que \\
1 & Igualmente importante a \\
3 & Moderadamente mais importante que \\
5 & Fortemente mais importante que \\
7 & Muito fortemente mais importante que \\
9 & Extremamente mais importante que \\
\hline
\end{tabular}

Fonte: Adaptado de Saaty (1977), apud Rosot (2000).

A eleição dos valores com base na escala de comparadores foi considerada um dos momentos mais importantes de todo o processo para delimitação da 
Sensibilidade Cultural, pois é nesse momento, que foi interpretado o ambiente rural para identificação e destaque da importância de cada Fator de Fragilidade Morfológica e cultural. Para o caso de bens culturais, por se tratar de condição de expressiva subjetividade, assim como particularidades únicas para cada situação de identificação e reconhecimento do objeto em sua realidade de patrimônio de interesse de preservação coletiva, entende-se que os parâmetros da fenomenologia e hermenêutica foram fundamentais por serem considerados os mais adequados a esta realidade, uma vez que se busca entender a essência dos fatos, o retorno às próprias coisas, a fim de se encontrar a realidade única que é a consciência ${ }^{11}$, que constitui os significados das coisas e das ações do sentido do mundo (REALE, 2008). Por meio deles se organizam os fatores a partir da realidade em que se apresentam, respeitando sua existência como única para o universo em questão. Além disso, entende-se que em cada situação a realidade se manifesta com distinção, percebe-se que os "valores objetivos hierarquicamente ordenados se impõem à intuição emocional, como a luz para os olhos e o som para o ouvido" (REALE, 2008, p.177). Assim a hierarquia encontrada para a fazenda Fortaleza não é necessariamente a mesma para outras fazendas ou patrimônios rurais.

Para os estudos de Sensibilidade Cultural, é importante que se respeite a condição que o objeto se apresenta em sua existência no mundo das coisas. Além disso, considere-se a experiência científica, as visitas a campo, o respeito ao bem cultural em sua condição resultante da transformação estética e histórica, além de incorporar o levantamento bibliográfico e identificação dos componentes do bem cultural em unidade conforme Brandi (2005). Uma equipe multidisciplinar, trabalhando em conjunto, com visitas de campo, debates, dentre outros, pode definir a escala que mais se aproxima da realidade do objeto a ser preservado na elaboração de uma adequada hierarquização de Fatores de Fragilidade Morfológica e Cultural - FFMC, que determinarão a Sensibilidade Cultural. Na pesquisa aqui desenvolvida optou-se por unir a ideia de que análise fenomenológica, levantamento bibliográfico, associado à observação em campo e experiência prévia, possibilitaram um resultado adequado de hierarquização de componentes dos bens culturais. A união das possibilidades anteriores permite a interdisciplinaridade com ampliação

11 A consciência contempla algo independente da sensibilidade e, portanto, a priori, mas funcionalmente ordenado para a constituição da experiência (REALE, 2008). 
das contribuições científicas necessárias a uma adequada preservação cultural do ambiente rural. A partir dessa realidade científica, utilizam-se os Fatores de Fragilidade Morfológica e Cultural - FFMC relacionados para a fazenda Fortaleza como de relevância na obtenção do resultado conforme Tabela 5, decorrente das reflexões resultantes das escolhas da Tabela 9. Cada elemento da matriz indica quanto o FFMC da coluna da esquerda é mais importante em relação a cada FFMC correspondente na linha superior. Logo, quando um FFMC é confrontado com ele mesmo, o único resultado possível é 1, pois possui igual importância (SANTOS et al, 2010). Esse limite é fundamental para a pesquisa, pois, a partir do momento em que todos os FFMC se entrecruzam uma vez, a matriz passa a ser apenas um espelho, ou inverso do procedimento inicial, gerando assim o resultado de relevância para a pesquisa, conforme se apresentam os elementos do bem cultural que são fundamentais para o modelo matemático em si (Tabela 5 e 6 ).

Tabela 5. Matriz de comparação pareada para os Fatores de Fragilidade Morfológica e Cultural do ambiente rural para os anos de 1970 e 2009 da fazenda Fortaleza.

\begin{tabular}{lccccccc}
\hline Fatores de Fragilidade Morfológica e Cultural & AAP & CD & F & VC & AC & CS \\
\hline Ativ agropastoris & AAP & 1 & $1 / 3$ & $1 / 3$ & $1 / 5$ & $1 / 7$ & $1 / 9$ \\
Corpos D'água & CD & 3 & 1 & $1 / 3$ & $1 / 3$ & $1 / 5$ & $1 / 7$ \\
Floresta & F & 3 & 3 & 1 & $1 / 3$ & $1 / 3$ & $1 / 5$ \\
Vias de circulação & VC & 5 & 3 & 3 & 1 & $1 / 3$ & $1 / 3$ \\
Ambiente Construído & AC & 7 & 5 & 3 & 3 & 1 & $1 / 3$ \\
Casa Sede & CS & 9 & 7 & 5 & 3 & 3 & 1 \\
\hline
\end{tabular}

Tabela 6. Fatores de Fragilidade Morfológica e Cultural para o ambiente rural relevantes para o modelo numérico da fazenda Fortaleza.

\begin{tabular}{lccccccc}
\hline Fatores de Fragilidade Morfológica e Cultural & AAP & CD & F & VC & AC & CS \\
\hline Ativ. agropastoris & AAP & 1 & & & & \\
Corpos D'água & CD & 3 & 1 & & & & \\
Floresta & F & 3 & 3 & 1 & & & \\
Vias de circulação & VC & 5 & 3 & 3 & 1 & & \\
Ambiente Construído & AC & 7 & 5 & 3 & 3 & 1 & \\
Casa Sede & CS & 9 & 7 & 5 & 3 & 3 & 1 \\
\hline
\end{tabular}


Possuindo os valores de importância relativa dos Fatores de Fragilidade Morfológica e Cultural que compõem o bem cultural, fazenda Fortaleza, quantificado em seus elementos, foi possível utilizar aplicativos computacionais específicos para determinar os pesos estatísticos para cada variável (SANTOS, et al, 2010). Sendo assim, os pesos estatísticos para os Fatores de Fragilidade Cultural Morfológica para o ambiente rural para os anos de 1970 e 2009 são mostrados na Tabela 7 e a metodologia do modelo numérico para cálculos consta, de acordo, com o Anexo A.

Tabela 7. Pesos estatísticos obtidos a partir dos cálculos conforme metodologia proposta por Saaty (1977).

\begin{tabular}{lcc}
\hline $\begin{array}{l}\text { Fatores de Fragilidade Morfológica e Cultural } \\
\text { para o ambiente rural - FFMC }\end{array}$ & $\mathbf{1 9 7 0 ~ e ~} \mathbf{2 0 0 9}$ \\
\hline Casa Sede & P1 & 0,4287 \\
Ambiente Construído & P2 & 0,2503 \\
Vias de Circulação & P3 & 0,1502 \\
Floresta & P4 & 0,0879 \\
Corpos D'água & P5 & 0,0528 \\
Atividades Agropastoris & P6 & 0,0310 \\
Razão de consistência (RC) & - & $\mathbf{0 , 0 5 2}$ \\
\hline
\end{tabular}

Baseado nos resultados da Tabela 7, o seguinte modelo matemático foi determinado, visando gerar os mapeamentos de Sensibilidade Cultural para o Ambiente Rural referente aos anos de 1970 e 2009:

Em que,

SCAR: sensibilidade cultural para o ambiente rural;

CS : Casa Sede;

AC: ambiente construído;

VC: vias de circulação;

F : floresta; 
CD : corpos d'água; e

AAP : atividades agropastoris.

ETAPA 05: Reclassificação dos mapas de Sensibilidade Cultural para o Ambiente Rural

Nesta etapa, os mapas de Sensibilidade Cultural para o ambiente rural (SCAR) para os anos de 1970 e 2009 da fazenda Fortaleza foram reclassificados em intervalos padronizados de $25 \%(0,25)$ da variação de 0 a 1 , totalizando quatro classes de sensibilidade, definidas como muito alta (SCAR1), alta (SCAR2), média (SCAR3) e baixa (SCAR4), mostradas na Figura 53.

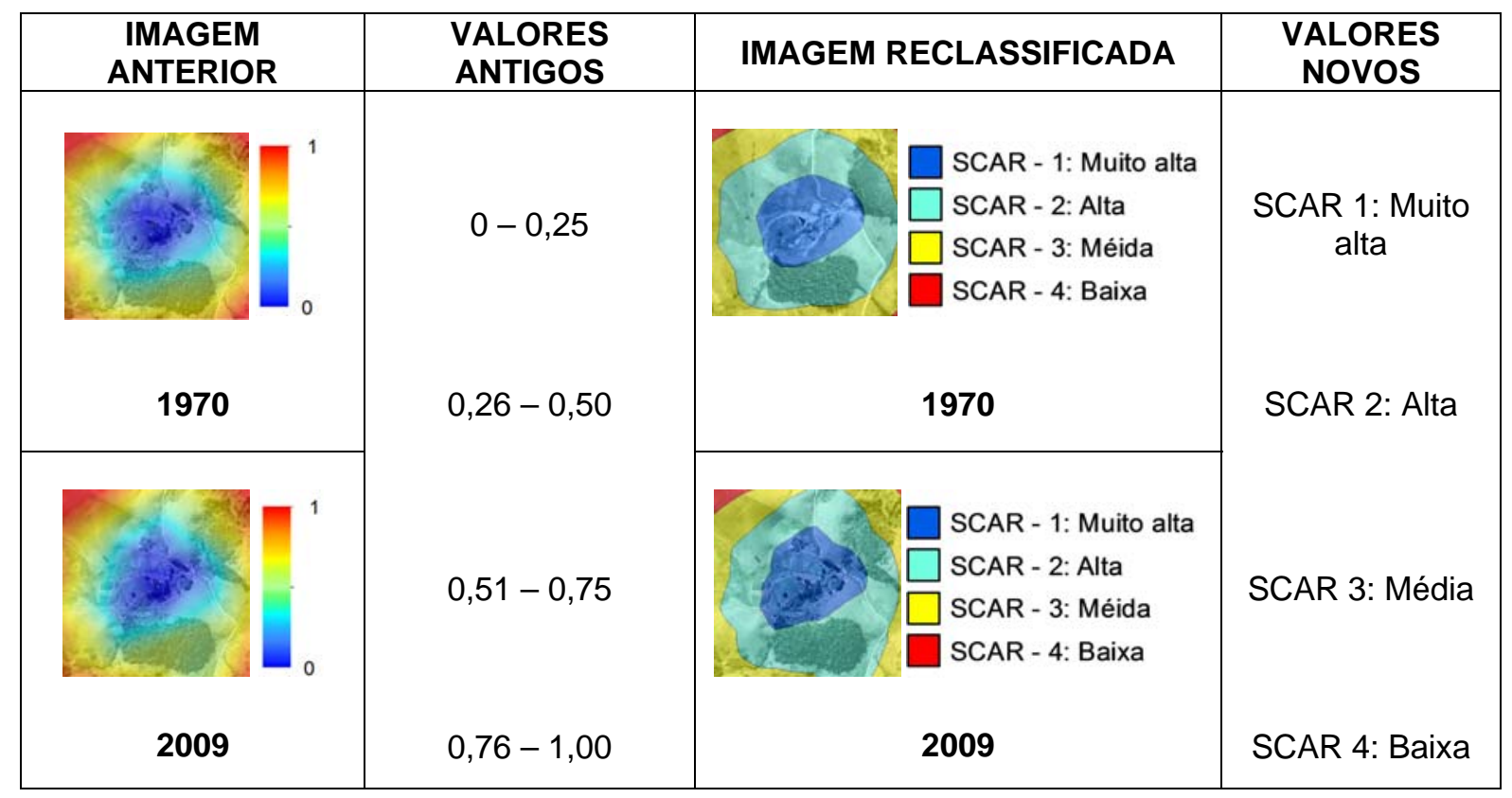

Figura 53. Reclassificação do mapa da Sensibilidade Cultural para o ambiente rural da fazenda Fortaleza para os anos de 1970 e 2009.

Todas as etapas necessárias para elaboração do mapeamento da Sensibilidade Cultural para o Ambiente Rural da fazenda Fortaleza para os anos de 1970 e 2009 são mostradas nos fluxogramas metodológicos exibidos nas Figuras 54 e 55, respectivamente. 


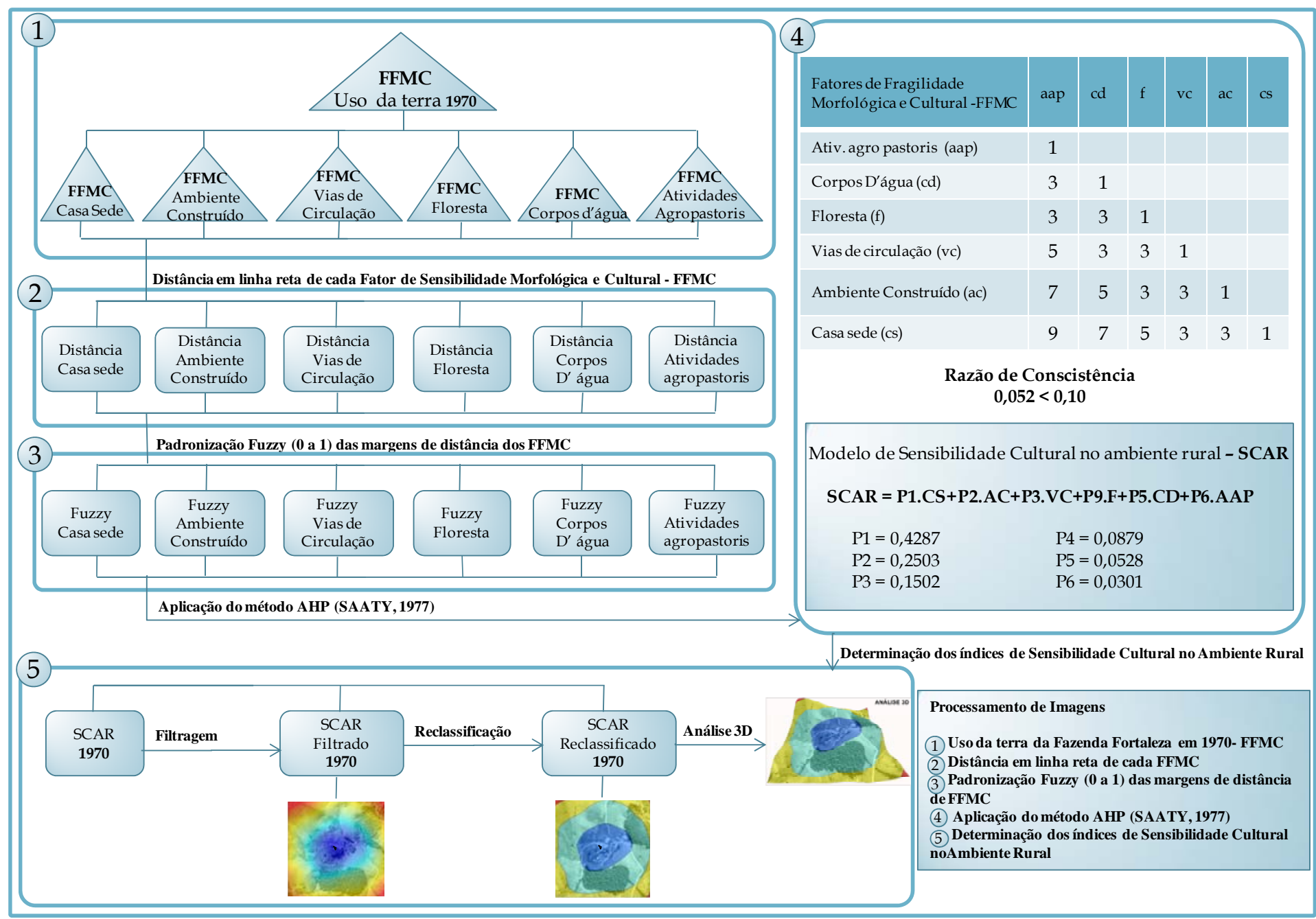

Figura 54. Fluxograma metodológico representativo das etapas necessárias para a elaboração do mapa de índice de sensibilidade cultural no ambiente rural para o ano de 1970 da fazenda Fortaleza, município de Alegre, ES. 


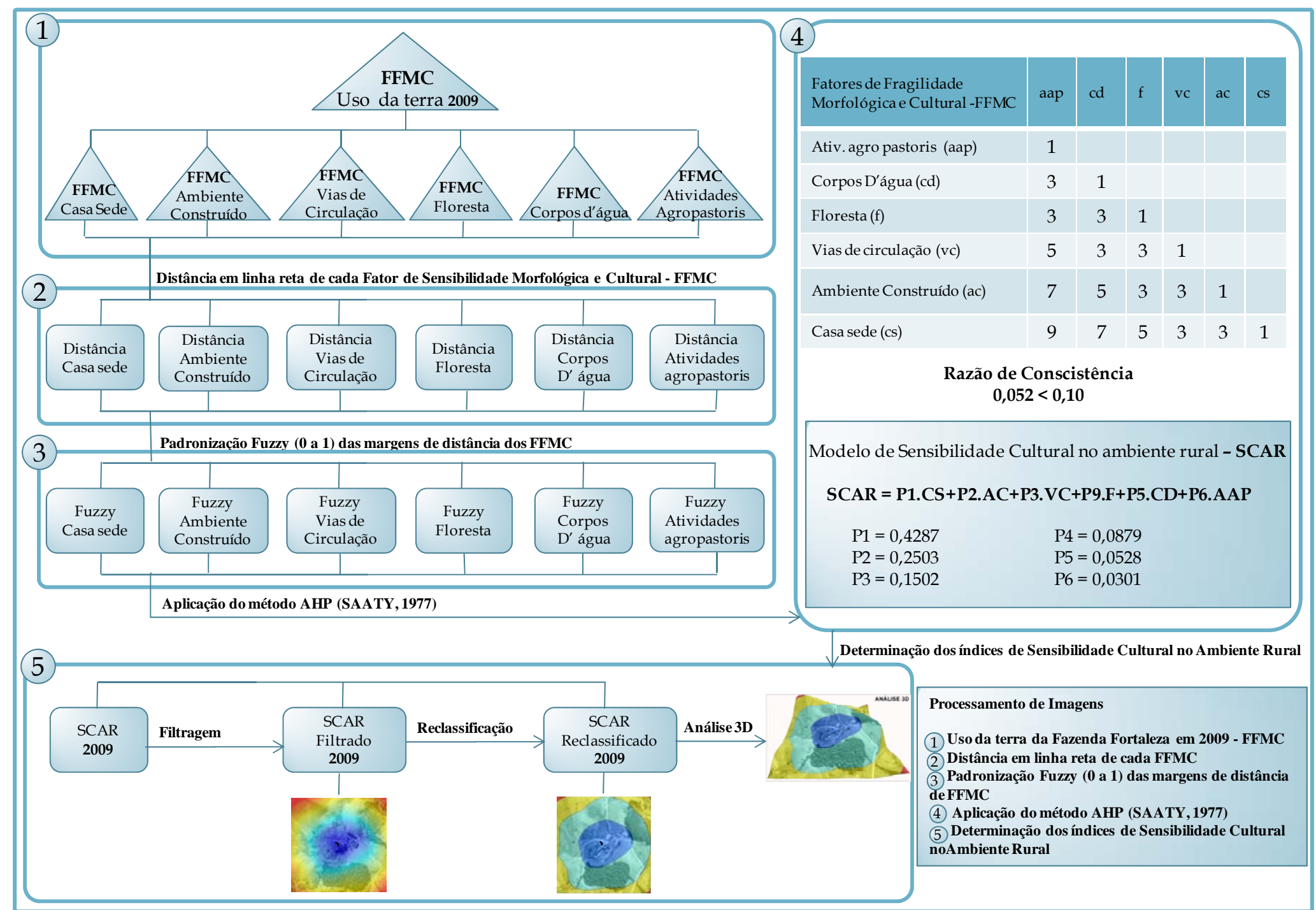

Figura 55. Fluxograma metodológico representativo das etapas necessárias para a elaboração do mapa de índice de sensibilidade cultural no ambiente rural para o ano de 2009 da fazenda Fortaleza, município de Alegre, ES. 
3. FAZENDA FORTALEZA: UMA ANÁLISE 


\subsection{Morfometria}

A variação da elevação da área em metros para a fazenda Fortaleza registra níveis que variam de 283,90 a 405,63 metros de altitude, conforme Figura 56. Sabendo da sua condição de empreendimento primordialmente cafeeiro, destaca-se que a altitude não é adequada ao cultivo do café, cuja produção é maior no alto dos morros, conforme tratados agrícolas. Confirma-se a orientação ao cultivo conforme literatura atual que indica altimetria acima de $450 \mathrm{~m}^{12}$ como ideal à produção de café de qualidade. Mesmo a condição altimétrica não sendo perfeita, a derrubada da mata atlântica colocava exposto o solo nutritivo e adequado à agricultura inicialmente.

Entretanto, tal medida, posteriormente, deixava o solo estéril, forçando a mobilidade do cultivo e em inúmeras situações, o abandono da fazenda, uma vez que o empreendimento deixava de ser lucrativo. Assim, a análise da elevação da área da fazenda Fortaleza mostra que, apesar de já ter produzido café, não é adequada a esse cultivo, considerando esse parâmetro. Entretanto para as demais culturas de subsistência e manutenção da fazenda, a variação da elevação se mostra apropriada a plantios diversos, tendo amplas áreas de baixa elevação e possibilitando o tratamento do solo com maior facilidade.

\footnotetext{
${ }^{12}$ Há dois tipos básicos de café, o arábica, bebida fina, exige altitude entre 450 a $800 \mathrm{~m}$, temperatura de $18^{\circ}$ a $22^{\circ} \mathrm{C}$; Já o café conilon, muito usado em café solúvel, necessita de temperatura de $22^{\circ}$ a $26^{\circ} \mathrm{C}$ e altitude de até $450 \mathrm{~m}$. Áreas de baixada são inaptas ao plantio mesmo com sistema de drenagem artificial (SANTOS, 2011).
} 


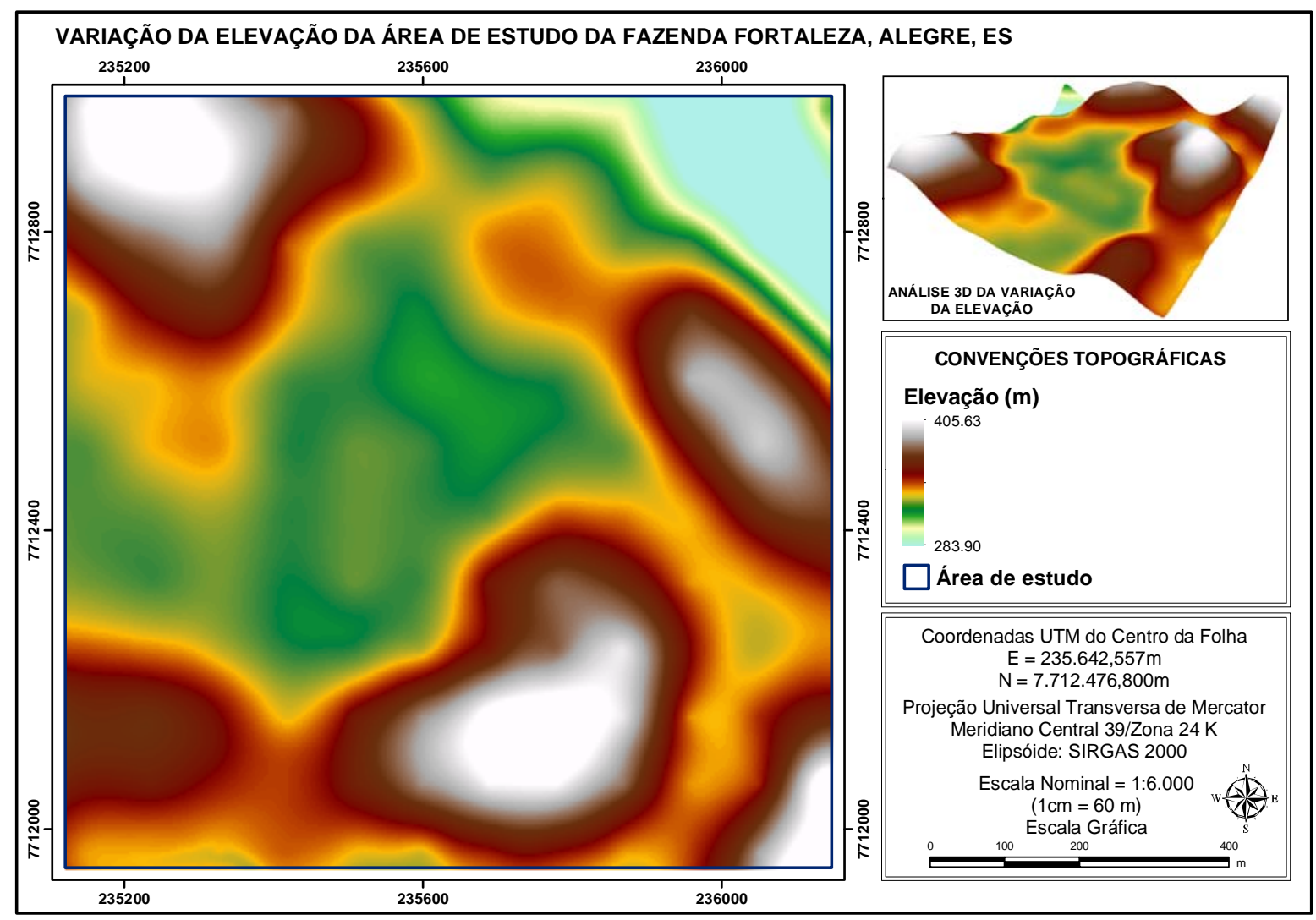

Figura 56. Variação da elevação no terreno da área de estudo da fazenda Fortaleza.

O perfil topográfico da área imediata à sede da fazenda evidencia sua condição de implantação em aclive, (ver Figura 57 e Figura 58), conforme referência construtiva mineira, confirmada pelo fato de seu fundador ser mineiro, de acordo com o Processo de Terras da Fazenda Fortaleza (INSTITUTO DE DEFESA AGROPECUÁRIA E FLORESTAL DO ESPÍRITO SANTO, 1924). Além disso, com o perfil topográfico é possível concluir por meio de dados altimétricos a condição de implantação da fazenda Fortaleza como pertencente ao denominado segundo grupo por Carrilho (2006), onde a Casa Sede comparece deslocada em relação ao eixo principal da composição, valendo-se de uma sucessão de planos, que vão se acomodando ao terreno, estes conjuntos oferecem um jogo de massas muito rico e variado, Figura 58. 


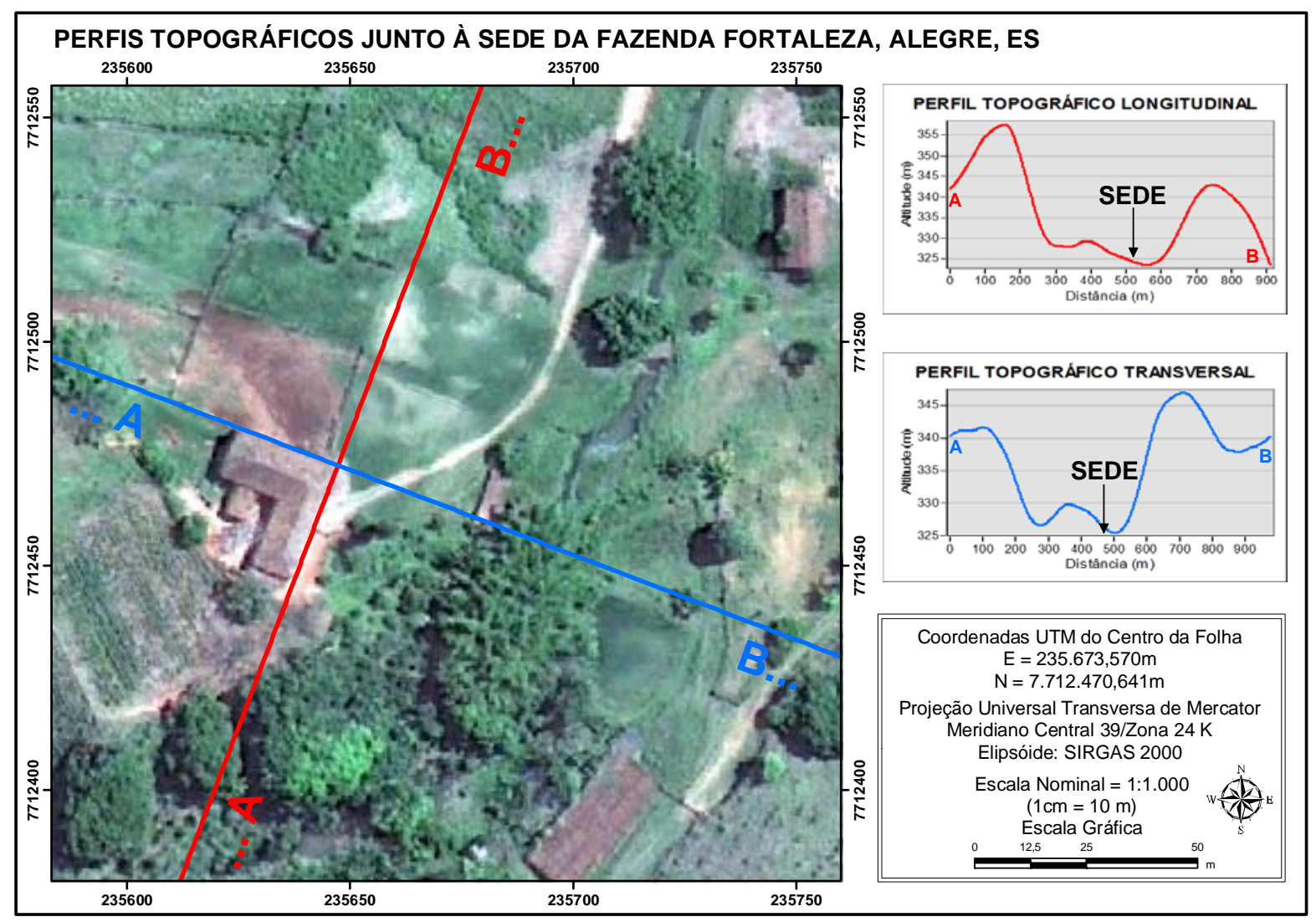

Figura 57. Perfil topográfico junto a Casa Sede da fazenda Fortaleza.

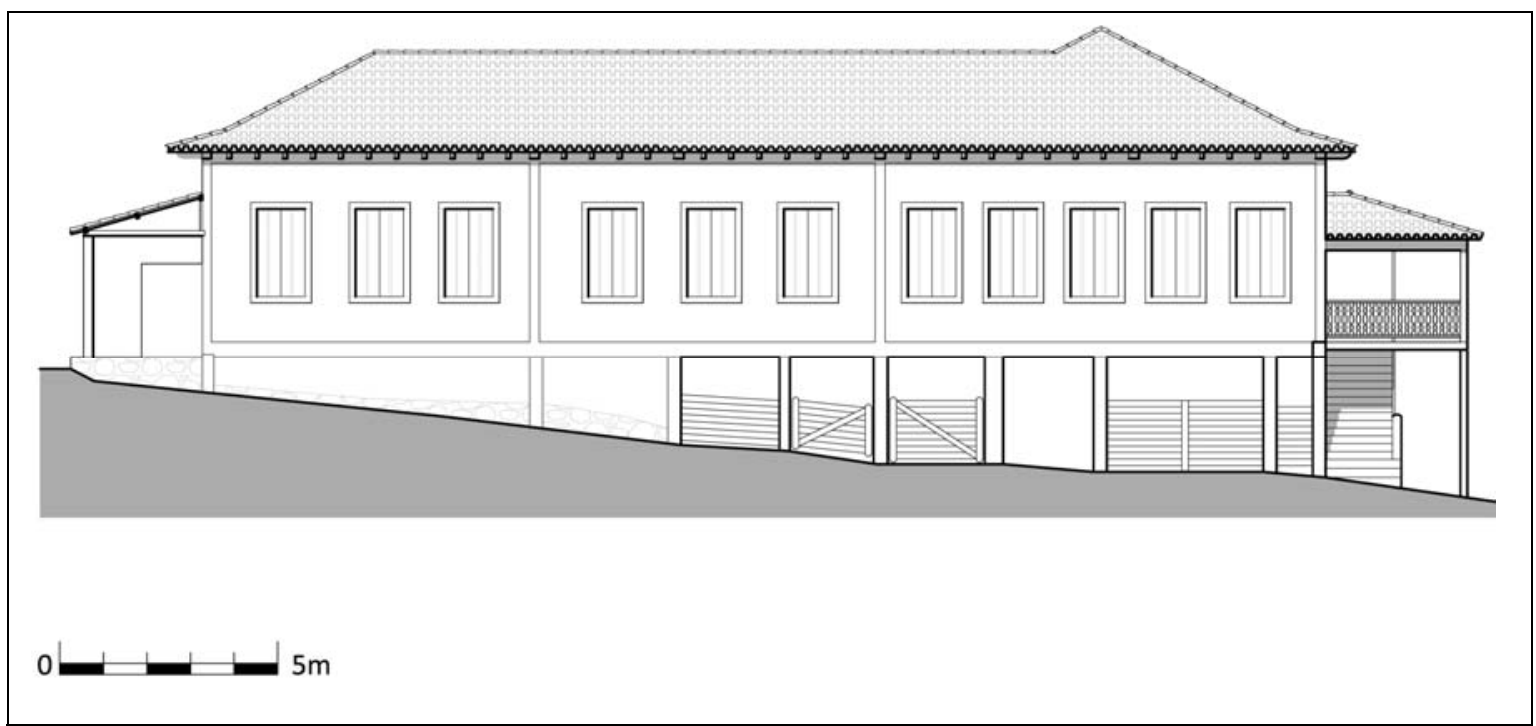

Figura 58. Elevação lateral esquerda Casa Sede da Fazenda Fortaleza. Desenho Mateus Rosada 2012.

Com a definição precisa dos intervalos de elevação na fazenda Fortaleza, evidencia-se a demarcação das faixas existentes em elevação por unidade de 
metragem, tornando visível e preciso os trechos mais ou menos adequados ao cultivo de espécies distintas. Além disso, auxilia-se a condição de avaliação para a implantação do complexo rural composto pelo ambiente construído, tendo a Casa Sede e os caminhos como importantes componentes vinculados à variação do intervalo de elevação. De acordo com Laborie (1799), os caminhos devem ser construídos com menor variação possível de elevação, o que pode ser observado a partir da Figura 59, em contraposição ao mapeamento do uso da terra.

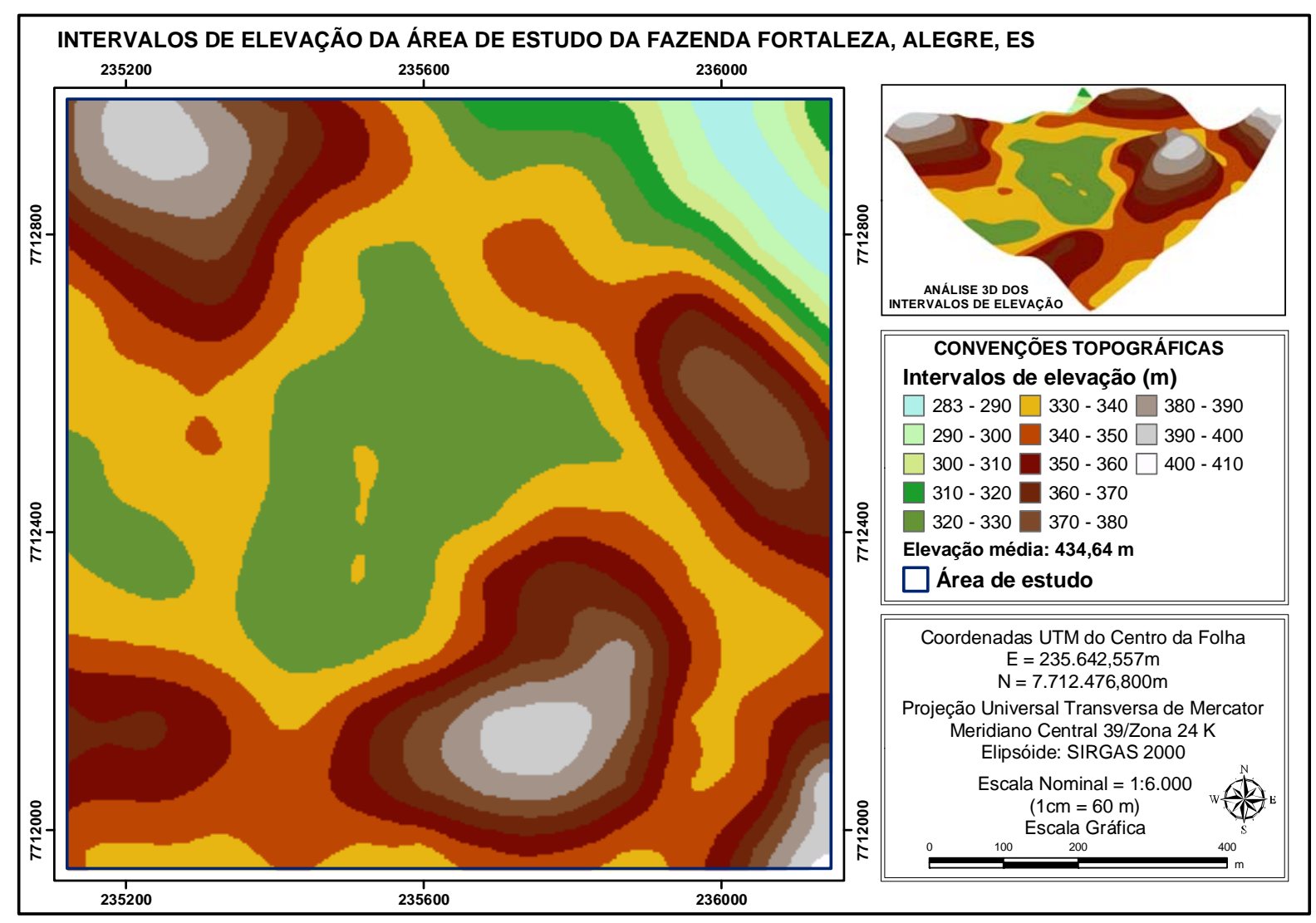

Figura 59. Intervalos de elevação da área de estudo da fazenda Fortaleza

A partir da tabela 8, destaca-se que ocorre o predomínio de intervalos de variação de elevação entre 340 a 350 metros com 23,02\% da área da fazenda, seguido do intervalo de 320 a 330 metros com 18,49\%, na faixa de implantação majoritária das instalações rurais e edificações, denominadas aqui como ambiente construído. Essa condição realça mais uma vez a localidade eleita para situar a fazenda, tendo em vista as orientações dos manuais de agricultura no que se refere aos parâmetros topográficos. Ao analisar a Figura 60, verifica-se que a fazenda 
Fortaleza localiza-se em área com variações de elevação em intervalos de 320 a 360 metros.

Tabela 8. Índice de variação de elevação

\begin{tabular}{ccc}
\hline Intervalos $(\mathbf{m})$ & $\begin{array}{c}\text { Número de } \\
\text { pixels }\end{array}$ & $\begin{array}{c}\text { Porcentagem } \\
\mathbf{( \% )}\end{array}$ \\
\hline $283-290$ & 16447 & 1,55 \\
$290-300$ & 18087 & 1,71 \\
$300-310$ & 13747 & 1,30 \\
$310-320$ & 21385 & 2,02 \\
$320-330$ & 195916 & 18,49 \\
$330-340$ & 243929 & 23,02 \\
$340-350$ & 200152 & 18,88 \\
$350-360$ & 121694 & 11,48 \\
$360-370$ & 88858 & 8,38 \\
$370-380$ & 65639 & 6,19 \\
$380-390$ & 45500 & 4,29 \\
$390-400$ & 27987 & 2,64 \\
$400-410$ & 517 & 0,05 \\
\hline Total & $\mathbf{1 0 5 9 8 5 8}$ & $\mathbf{1 0 0 , 0 0}$ \\
\hline
\end{tabular}

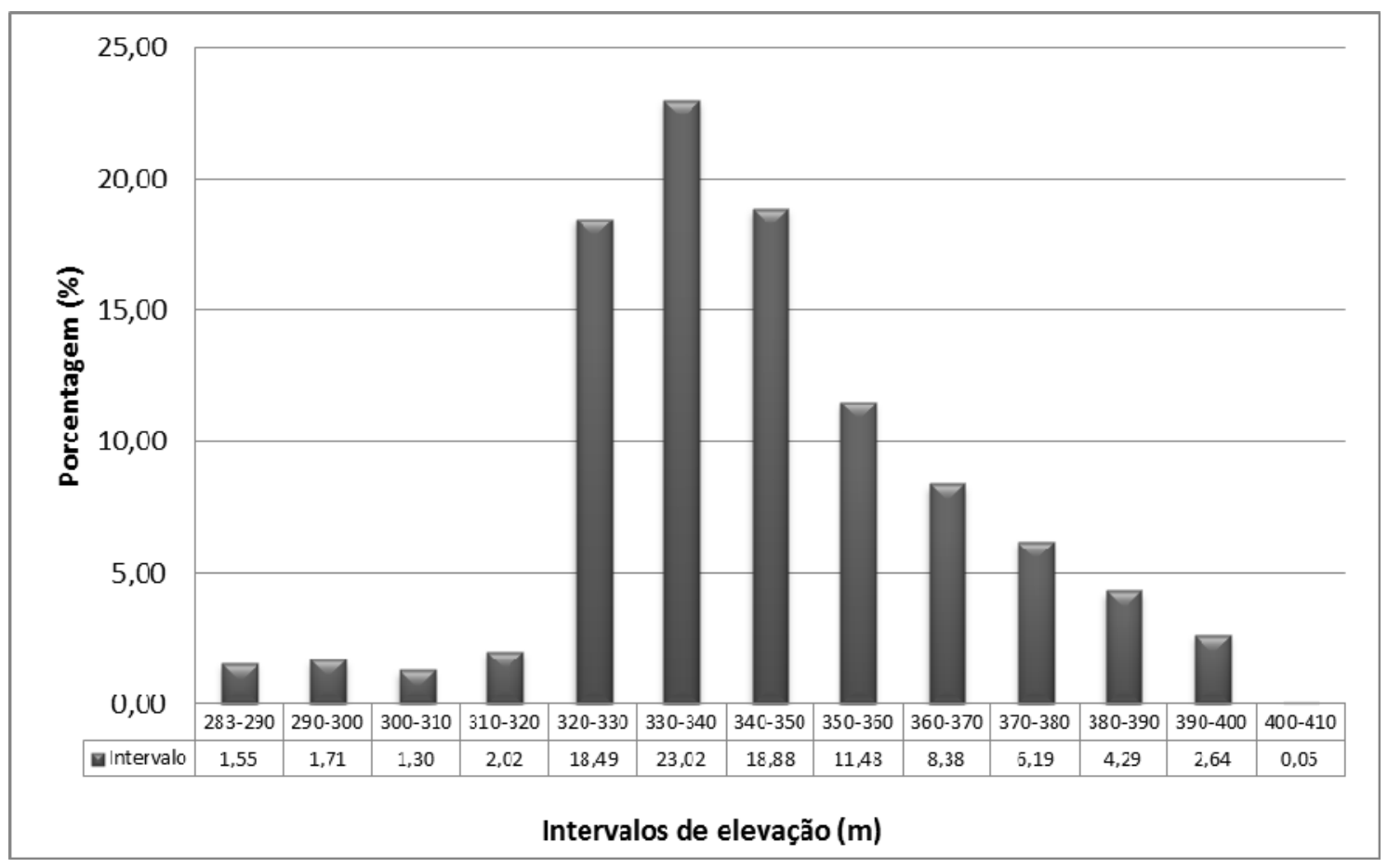

Figura 60. Índice de intervalo de elevação 
A orientação das vertentes conforme Figura 61, possibilita importante análise principalmente para a fazenda Fortaleza, no que se refere à posição adequada ao plantio dos cafezais conforme prescreve os manuais de agricultura. A topografia da fazenda Fortaleza possui configuração, cuja morfometria traduz predomínio de vertentes que se voltam para nordeste $(16,93 \%)$ e sudoeste $(16,80 \%)$, seguidas pelas orientações sul $(12,24 \%)$, leste $(11,65 \%)$, e com índices aproximadamente iguais às vertentes que se voltam para noroeste $(10,55 \%)$, sudeste $(10,35 \%)$ e oeste $(9,92)$, conforme Figura 62.

Se considerar o prescrito por Laborie (1799) ao se tratar de lugares baixos e quentes, as plantações de café devem se voltar para exposição solar norte e oeste, porque são mais frias e melhores. Já nos locais montanhosos e altos, a exposição solar adequada é a leste e sul, pois o calor é menor; o que pode ainda ser bem observado através do mapa de sombreamento, conforme Figura 62.

Tendo em vista que a variação da elevação na fazenda é pequena, com intervalos predominantes entre 320 e 360 metros, entende-se que nela predominam as terras baixas para o cultivo do café, o que acarreta localização dos cafezais em encostas voltadas para norte e oeste, que representam juntas apenas $15 \%$ da área disponível. Há que se observar ainda que em termos de uma média entre as orientações existentes na fazenda, considera-se o predomínio de $17,12^{\circ}$ sul, o que seria excelente se a variação de elevação fosse maior que 400 metros. Reflexões como essa auxiliam no processo de compreensão da trajetória histórica da fazenda e identificação de elementos que contribuíram para alguns resultados morfológicos e econômicos atuais.

Para a ampliação dos esclarecimentos quanto à presença do calor e do sol nas áreas altas e baixas da fazenda, utilizar as informações do mapa de sombreamento são fundamentais (Figura 63), pois é possível se eleger qualquer hora do dia e posição angular do sol em relação à Terra para se compreender as áreas com maior ou menor variação de iluminação, observando a necessidade dos cultivos e implantação do empreendimento rural. 


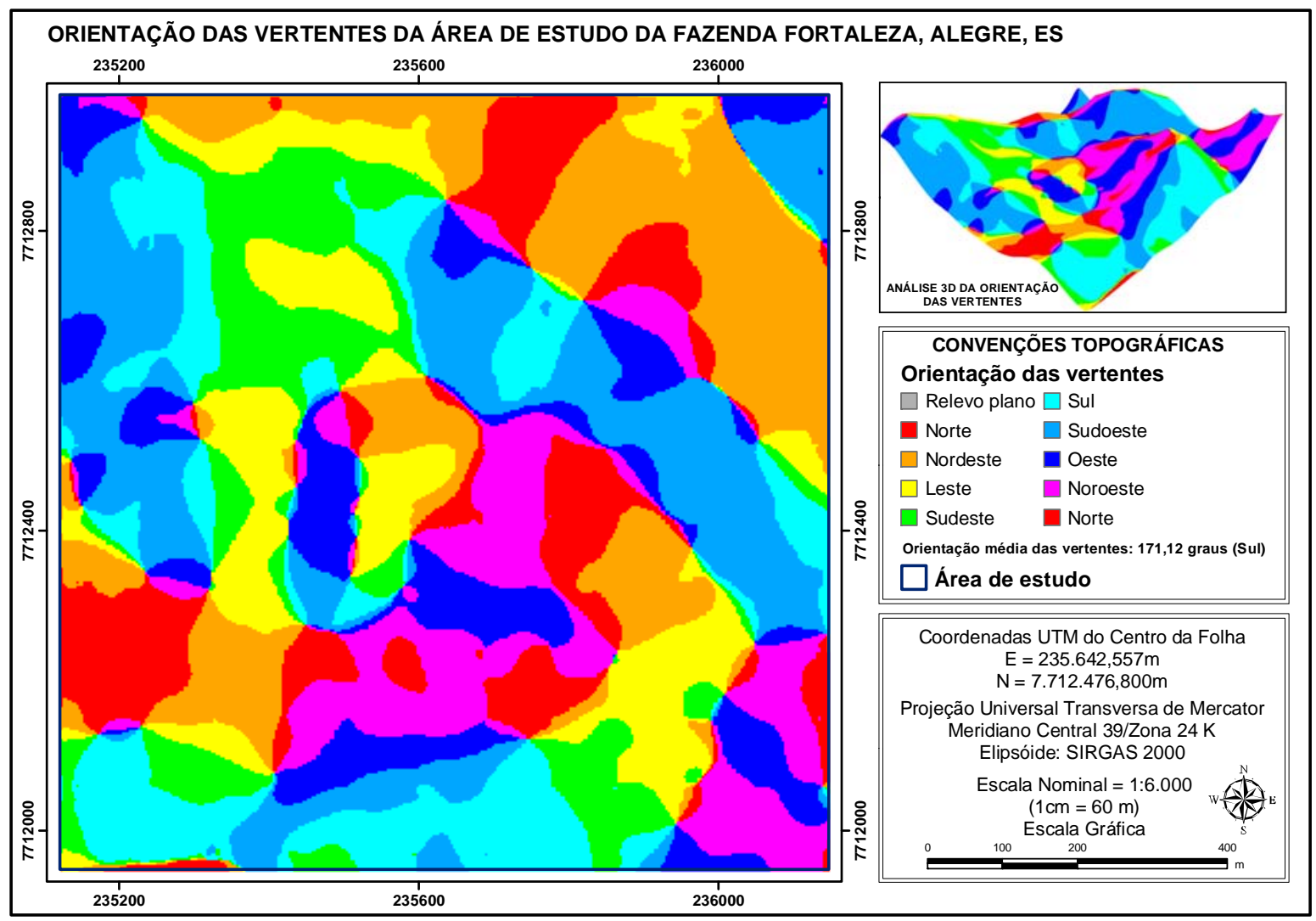

Figura 61. Orientação das vertentes no terreno da área de estudo da fazenda Fortaleza.

Tabela 9. Índice de orientação das vertentes por pixels

\begin{tabular}{|c|c|c|}
\hline Orientação ( ${ }^{\circ}$ ) & Número de pixels & Porcentagem (\%) \\
\hline Relevo Plano & 7 & 0,00 \\
\hline Norte & 66157 & 6,24 \\
\hline Nordeste & 179391 & 16,93 \\
\hline Leste & 123499 & 11,65 \\
\hline Sudeste & 109740 & 10,35 \\
\hline Sul & 129698 & 12,24 \\
\hline Sudoeste & 178044 & 16,80 \\
\hline Oeste & 105159 & 9,92 \\
\hline Noroeste & 111849 & 10,55 \\
\hline Norte & 56314 & 5,31 \\
\hline Total & 1059858 & 100,00 \\
\hline
\end{tabular}




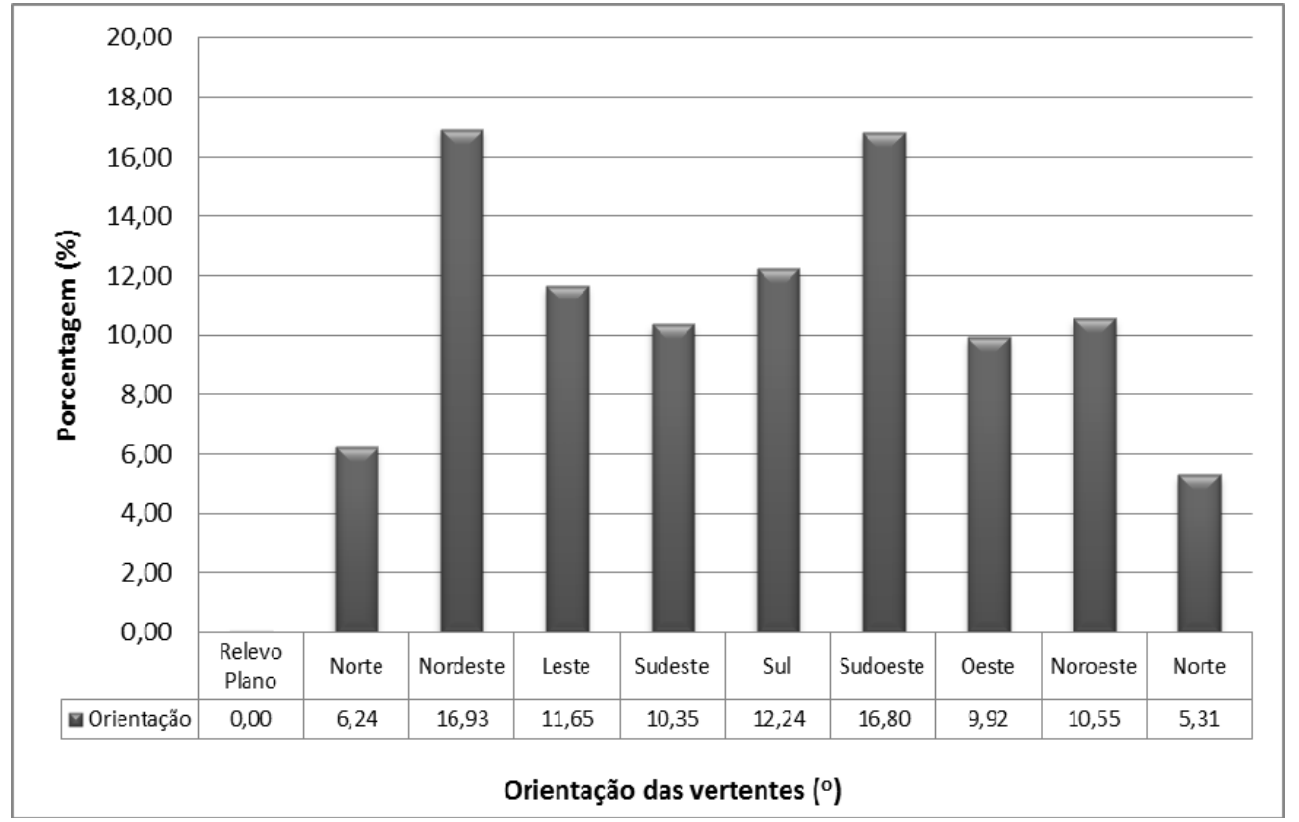

Figura 62. Orientação das vertentes para a área de estudo da fazenda Fortaleza.

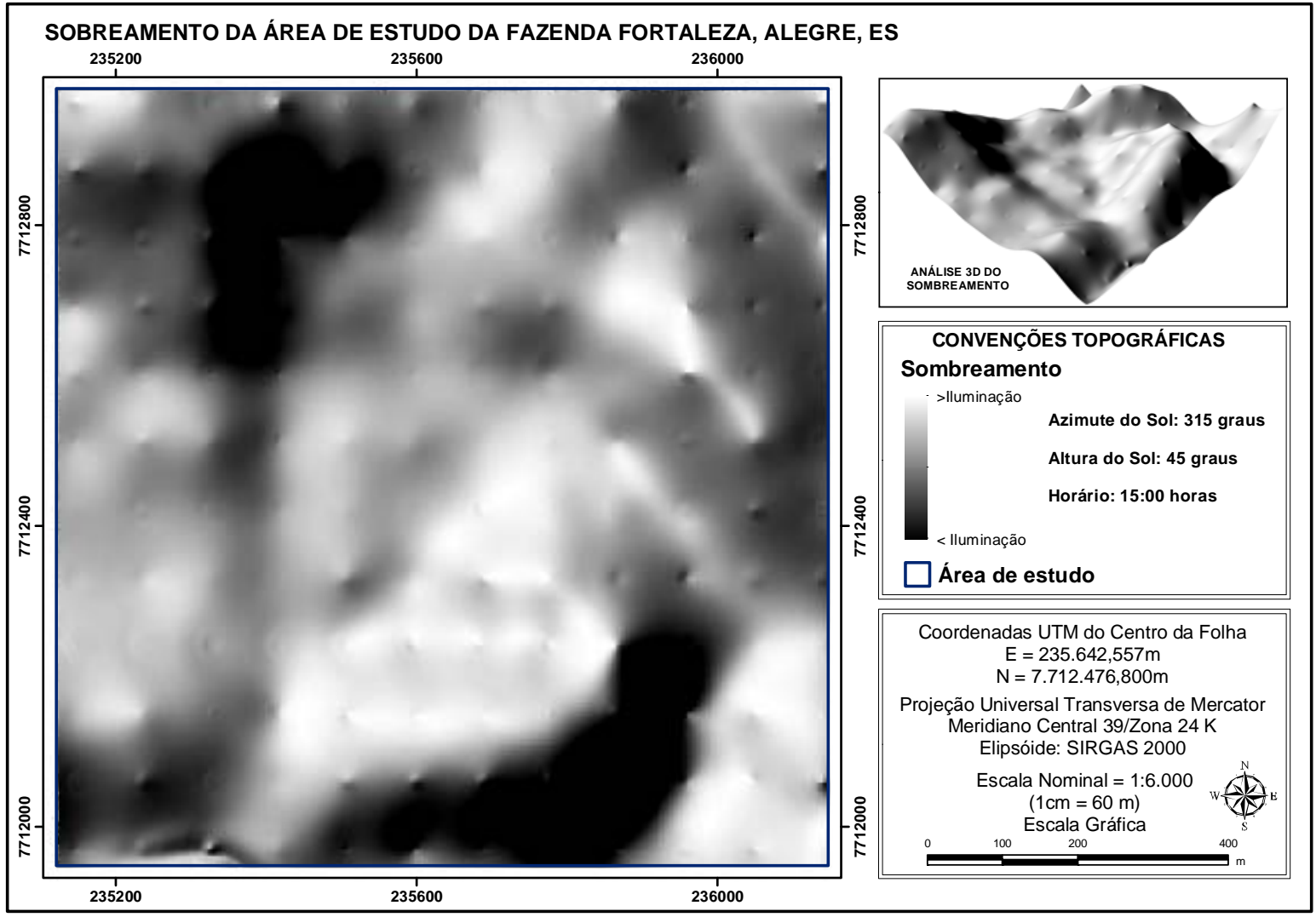

Figura 63. Sombreamento da área de estudo da fazenda Fortaleza. 
A declividade, conforme Figura 64, representa poderoso instrumento de análise para o ambiente rural, juntamente com a direção do fluxo d'água (Figura 66). Carrilho (2006) esclarece como a declividade influencia na tipologia e conjunto de edificações que compõem o empreendimento rural.

A topografia condiciona o tipo de agricultura, assim como os demais parâmetros morfométricos. Laborie (1799) sugere a manutenção inicialmente, de raízes de árvores que foram cortadas na propriedade, para se evitar a degradação da terra e a lavagem dos nutrientes pela chuva:

é fácil de se conhecer [...], que o terreno dos morros não são de longa duração; e por isso para se lhe prolongar o gozo, se faz indispensável proibir aos escravos barbechar, ou arrancar as raízes das árvores, que lastram sobre a terra, e totalmente se entrelaçam apos as derribadas. Esta precaução é de uma grande utilidade, para a conservação da terra. Em quando as raízes subsistirem, as águas não farão preza na terra; e por este meio os pés de cafés tem tempo de crescer, e de cobrir a seu turno as raízes; e a terra, que as rodeia, antes da inteira consumação das outras, o que dá lugar de resistir alguns anos mais (LABORIE, 1799, p.43)

Conforme dados de declividade gerada para a fazenda Fortaleza, (Figura 64), verifica-se o predomínio de relevo plano, suavemente ondulado, somando um total de $57,34 \%$ da área estudada em detrimento do relevo fortemente ondulado, montanhoso e escarpado, que juntos somam 42,66\%. Entretanto, é possível fazer outra leitura da declividade ao se agrupar os trechos de relevo fortemente ondulado e relevo montanhoso, que agregam áreas de declividade entre $20 \%$ a $75 \%$, e entender que juntos são 74,38\% predominantes, conforme a tabela 10.

Tabela 10. Incidência da declividade por tipo de relevo por

\begin{tabular}{|c|c|c|}
\hline Declividade (\%) & Número de pixels & Porcentagem (\%) \\
\hline $0-3 \%$ (Relevo plano) & 52123 & 4,92 \\
\hline 3 - 8\% (Relevo suavemente ondulado) & 174469 & 16,46 \\
\hline 8 - 20\% (Relevo ondulado) & 381070 & 35,95 \\
\hline 20 - 45\% (Relevo fortemente ondulado) & 407332 & 38,43 \\
\hline 45 - 75\% (Relevo montanhoso) & 44833 & 4,23 \\
\hline > 75\% (Revelo escarpado) & 31 & 0,00 \\
\hline Total & 1059858 & 100,00 \\
\hline
\end{tabular}




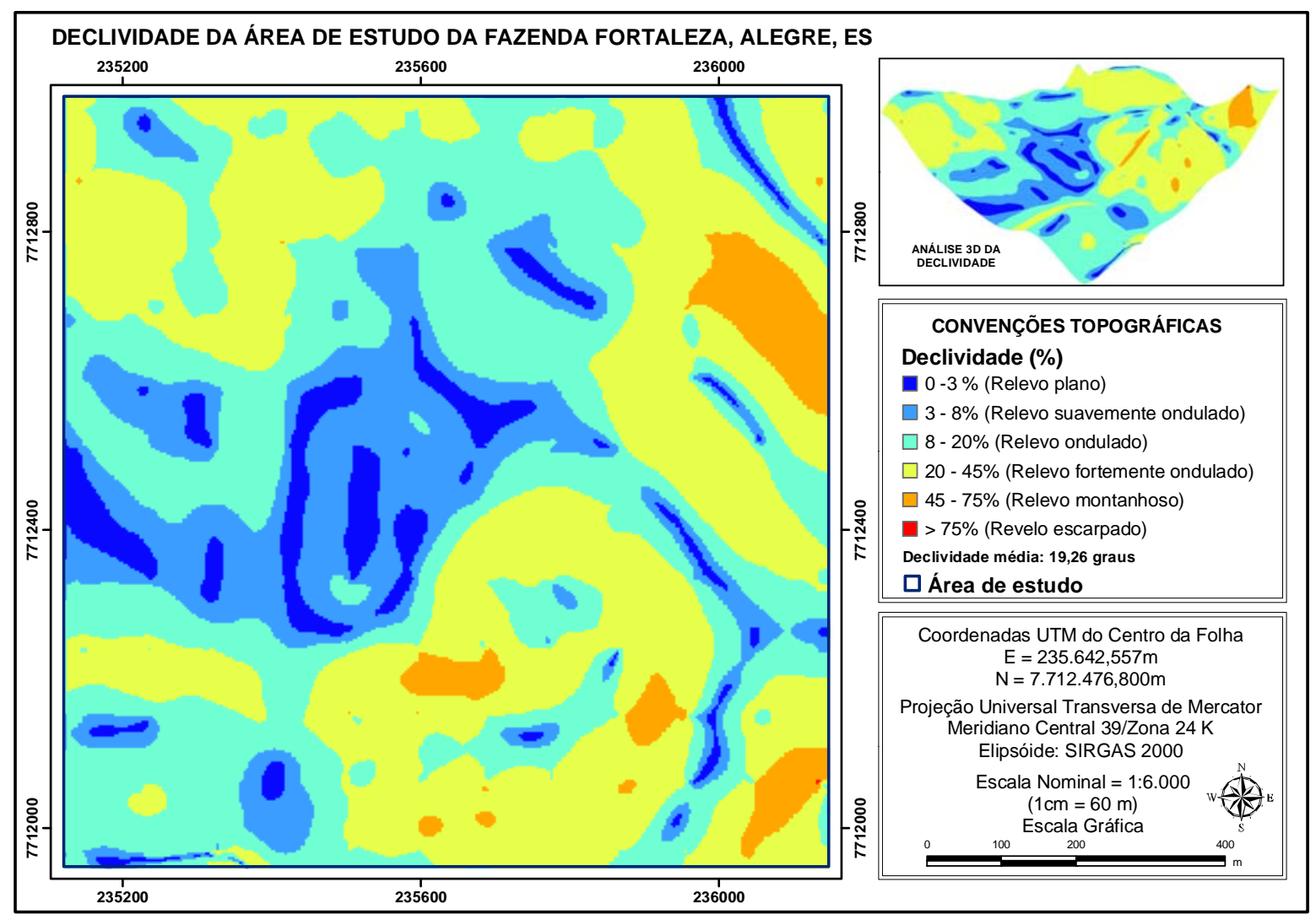

Figura

64. Declividade no terreno da área de estudo da fazenda Fortaleza.

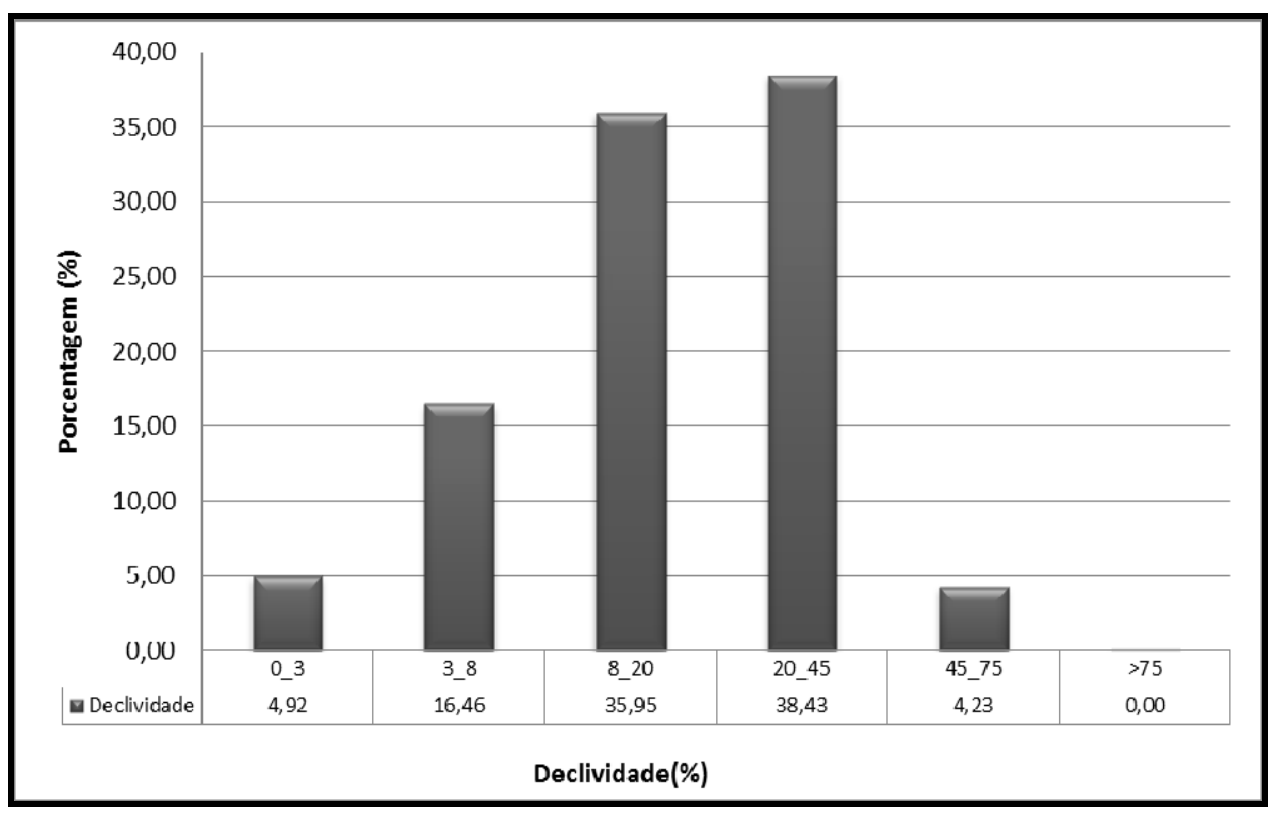

Figura 65. Declividade para a Fazenda Fortaleza.

Cabe destacar que nos tratados agrícolas, a mata associada à topografia também trazia leituras e conclusões quanto à condição da terra e sua fertilidade. 
Muitas terras boas há, que nas cabeças dos morros e das meias laranjas apresentam madeira, que só dão em abundância em terrenos inferiores, e que aliás são madeiras de primeira qualidade para construção, como a guarauna, o ipê, a aguarapiapunha. O que é uma dupla vantagem, porque estes cabeços de morros e outeiros produzem muito café e mandioca, e depois de mais safados também dão excelente feijão e milho (WERNECK, 1878, p.15).

Ao se comparar os dados gerados pela variação de elevação (Figura 60) e declividade (Figura 65), percebe-se que apesar da fazenda Fortaleza possuir o predomínio de relevo fortemente ondulado, está em cotas altimétricas de baixa altitude, em sua maioria. Ou seja, conforme esses parâmetros, a fazenda não é adequada para o cultivo do café de qualidade, apesar de boa aguada, dentre outros condicionantes colocados por Werneck (1878). O mapa de direção de fluxo d'água possui três importantes divisores de água, possibilitando o direcionamento diverso para o fluxo. Entretanto cabe destacar que o predomínio da direção do fluxo d'água é para noroeste em média, mas se observar a Figura 67, nota-se que a direção predominante é para oeste e sul, local onde foram instalados os complexos edificados para o custeio da fazenda, tendo a Casa Sede em posição central. Criteriosamente evidenciando a escolha adequada do local para fundação da fazenda conforme Werneck (1878), redita-se que a utilização dos parâmetros morfométricos auxilia a percepção da fazenda em sua condição única, como unidade, tanto para a compreensão de sua fundação no século XIX, como para sua preservação enquanto bem cultural, além de reforçar o entendimento das intenções e planejamento para a fundação de uma fazenda conforme manuais agrícolas do século XIX.

Tabela 11. Índice de direção de fluxo d'água

\begin{tabular}{ccc}
\hline Direção de fluxo $\left(^{\circ}\right)$ & Número de pixels & Porcentagem (\%) \\
\hline Leste & 82308 & 7,77 \\
Sudeste & 90247 & 8,52 \\
Sul & 167602 & 15,81 \\
Sudoeste & 148098 & 13,97 \\
Oeste & 200954 & 18,96 \\
Noroeste & 89165 & 8,41 \\
Norte & 125319 & 11,82 \\
Nordeste & 156165 & 14,73 \\
\hline Total & $\mathbf{1 0 5 9 8 5 8}$ & $\mathbf{1 0 0 , 0 0}$ \\
\hline
\end{tabular}




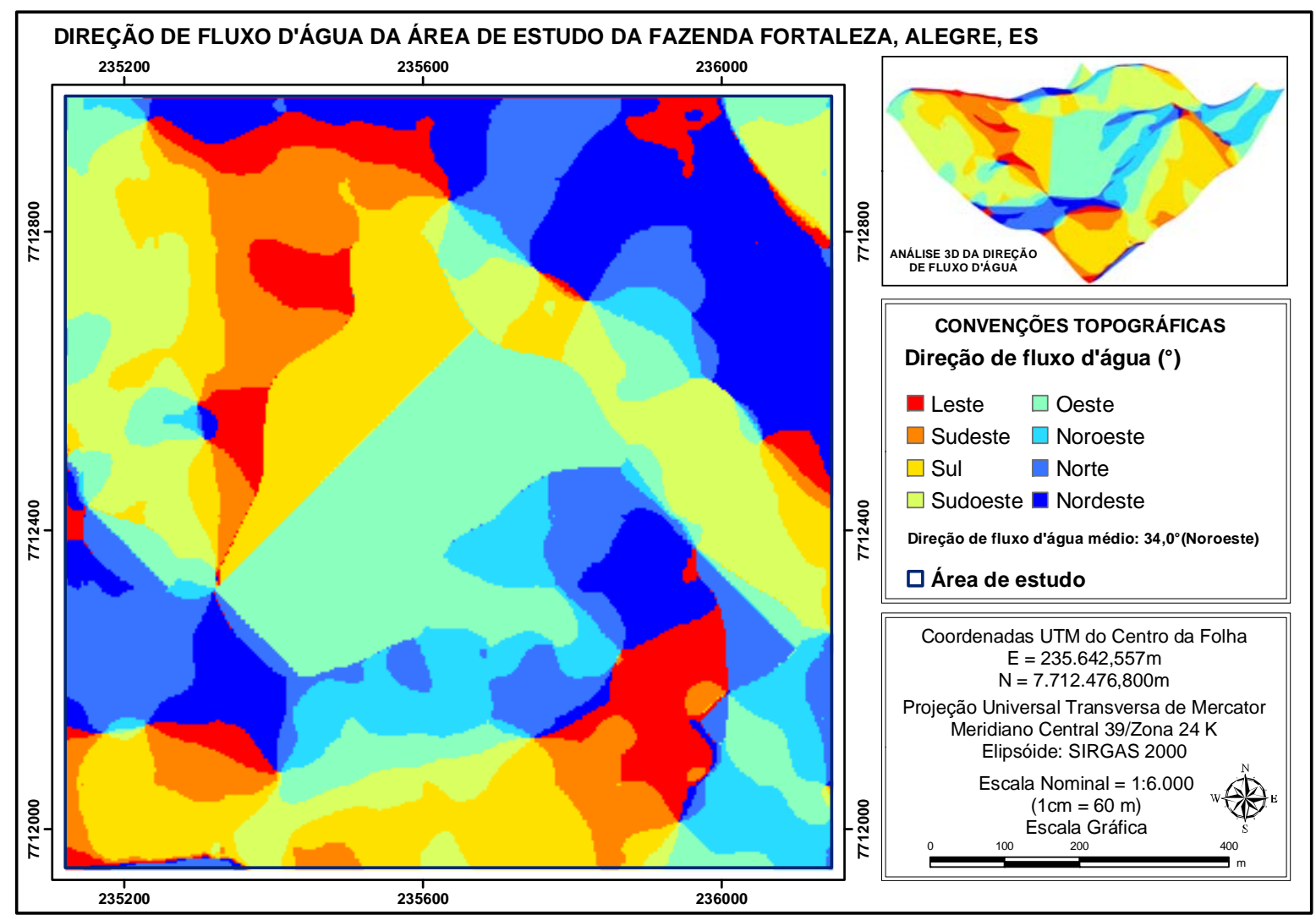

Figura 66. Direção do fluxo d'água no terreno da área de estudo da fazenda Fortaleza.

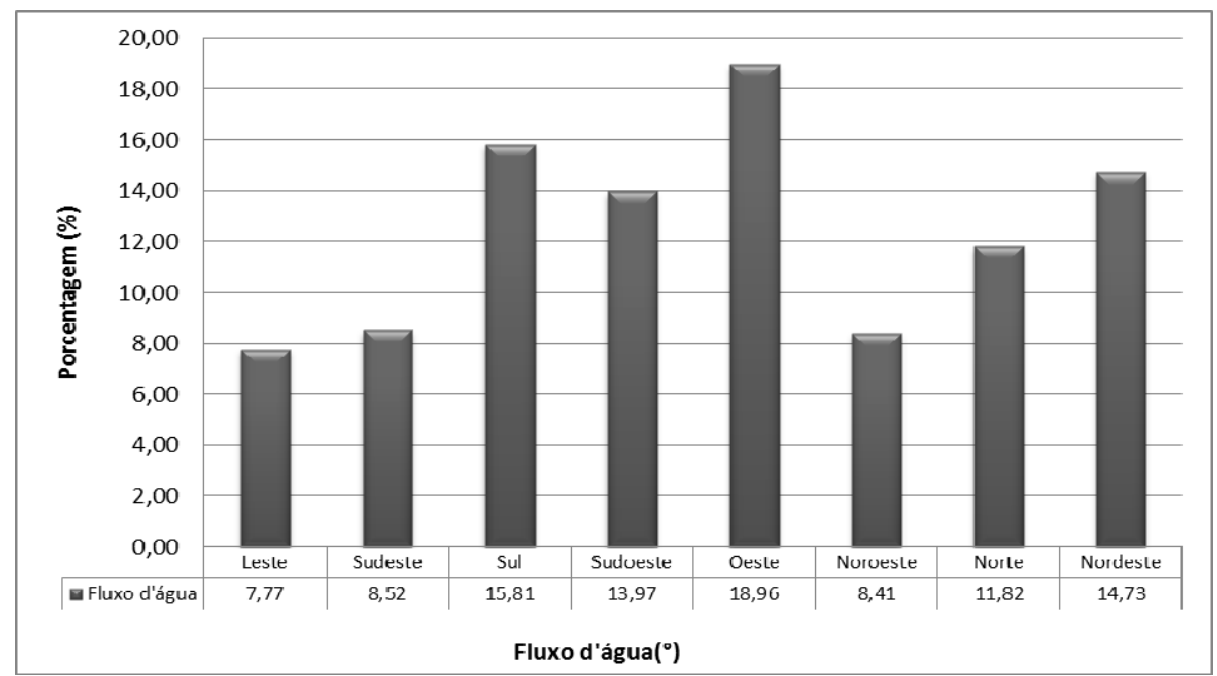

Figura 67. Direção do Fluxo d'água para a área de estudo da fazenda Fortaleza, Alegre, ES.

Considerando-se os parâmetros morfométricos do local previsto para instalação de uma fazenda, conforme os manuais agrícolas do século XIX, 
determinam-se o local para a sede das edificações e áreas adequadas ao cultivo e custeio da fazenda. Na sequência o lavrador deve:

traçar a planta da fazenda, com designação da casa destinada à sua residência, à do pessoal livre e escravo, e compreendendo não só as máquinas que forem necessárias à especialidade agrícola, a que se destinarem, como também os paióis, armazéns, estrebarias e mais habitações dos animais domésticos (WERNECK, 1878, p.3).

O conhecimento do local traz a segurança adequada para implementar o empreendimento agrário com segurança, iniciar a construção do complexo edificado e o cultivo da terra. Dados obtidos a partir da direção do fluxo d'água conforme tabela 11, declividade, orientação das vertentes, intervalos de elevação, variação da elevação, perfil topográfico e modelo digital de sombreamento, trazem, a oportunidade de entendimento de condições, físicas e climáticas para estudo da fazenda Fortaleza, que possibilitam na atualidade não apenas reflexões para compreensão de sua condição de bem cultural, mas ainda como objeto histórico e atual com geração de dados para gestão sustentável do seu acervo.

\subsection{O uso da terra}

No início do desenvolvimento humano, a transformação parcial da paisagem natural pelo homem socialmente organizado da origem a uma paisagem cultural. Mesmo nos graus mais elevados da civilização, a natureza forma um substrato sempre presente que suporta $\mathrm{e}$, mais ou menos, impregna toda a paisagem pela sua própria contribuição na sua configuração geral, como as formas do relevo e da vegetação. Mas, nestes estágios avançados, a maioria das paisagens representa a transformação de paisagens culturais previamente existentes. $O$ uso da terra responde de forma mais direta aos impulsos de transformação funcional e a sua 
influência na paisagem urbana histórica, representando elemento de forte interferência (COZEN, 2009).

Para a elaboração do uso da terra da fazenda Fortaleza foram adotadas como Vias de Circulação as estradas não pavimentadas; rios e lagos foram denominados Corpos D'água; edificações e instalações rurais, como Ambiente Construído; café, anexado à área agriculturada, adaptando à realidade da fazenda Fortaleza as orientações do IBGE (2006). Avaliar a fazenda Fortaleza como unidade, não impossibilita as análises de seus componentes, na busca pelo entendimento como bem cultural. De acordo com a Figura 68, a fazenda Fortaleza, em 1970, é constituída por $73,55 \%$ de pastagem em relação à área total estudada. Tendo em vista ter sido fazenda de café, conforme consta do Processo de Terras (INSTITUTO DE DEFESA AGROPECUÁRIA E FLORESTAL DO ESPÍRITO SANTO, 1924), no século XIX, a pastagem era para aproximadamente 80 cabeças de gado bovino, 20 muares e 80 porcos de pasto, o que exigia menor superfície de pastagem na totalidade das terras da fazenda.

Essa ordem, em 2009, reduziu para 73,09\% de pastagem, evidenciando mudança de cultura, ou cultivo que sustenta o imóvel rural. Atualmente na fazenda, as cabeças de gado bovino não necessitam de toda esta área de pastagem; nota-se que a agricultura local representa a subsistência, como se percebe a partir do registro de apenas 2,20\% de área agriculturada (Figura 69), registrando expressivo aumento no cultivo da terra. Os corpos d'água também aumentaram pouco, o que significa, pelo menos, a manutenção do existente, com abertura, talvez, de açude para o gado bovino beber água. A rocha diminuiu e o ambiente construído, juntamente com as vias de circulação, ampliaram-se significativamente, evidenciando maior dinamismo na utilização da fazenda e seus recursos e indicando a busca por princípios de sustentabilidade. Mantém ainda evidente como referência da unidade da fazenda como íntegra, a incidência expressiva dos corpos d'água e caminhos, com 1,79\% e 2,22\%, respectivamente. Percebe-se que, de acordo com os manuais de agricultura do século XIX, confirma-se a importância desses elementos na conformação de uma fazenda. Florestas com 19,19\% de incidência na área são relevantes para o conhecimento da formação e manutenção da unidade do bem cultural, uma vez que delas se monta a estrutura rural no século XIX, e na atualidade, representam elemento importante para a sustentabilidade da paisagem. 
Outro elemento destacado no imóvel é a rocha, que conforme Laborie (1799) representa tradicionalmente material de construção para as edificações, caso seja necessário. No que se refere ao ambiente construído, mesmo que transformado, representa $0,35 \%$ do uso da terra na fazenda Fortaleza, se mostrando assim como estruturador do empreendimento rural.

Questões de relevância que devem ser lembradas tratam dos esclarecimentos de Cassar (1997) quanto ao controle dos efeitos do tempo sobre a edificação; de acordo com ele, a cobertura vegetal, árvores e arbustos podem ser utilizados para guiar, filtrar, obstruir ou deflexionar o padrão do movimento de ar. As copas das árvores também previnem turbulências, árvores produzem maior proteção às edificações que barreiras sólidas e sua proteção excedem a 20 vezes a sua altura. Edifícios mais altos têm grandes zonas de calmaria na base, ao contrário dos edifícios mais baixos. Percebe-se que este fator colabora para o entendimento da durabilidade das casas que constam de tipologia, como a sede da fazenda Fortaleza, de referência mineira setecentista com predomínio de característica assobrada.

Ao se observar o uso da terra mapeado em 1970, verifica-se que a distribuição das manchas de floresta pela propriedade consta de núcleos mais próximos à edificação, se comparado com o uso da terra de 2009, conforme Figura 68 e 69. Isso indica que para 1970, a Casa Sede e seu complexo edificado estavam mais adequados aos parâmetros de conservação indicados por Cassar (1997). O instrumento de mapeamento do uso da terra auxilia nas reflexões que podem contemplar desde parâmetros de preservação para as questões macros até aqueles de incursão direta no edifício, uma vez que muito deles abrigam acervo a ser preservado. Portanto, o edifício é colocado como embalagem de bens culturais móveis, tendo as diversas variáveis climáticas e ambientais como condicionantes básicos para a conservação de bens culturais em suas mais diversas escalas, conforme define Cassar (1997), desde objetos, o edifício é o ambiente que os conforma. 


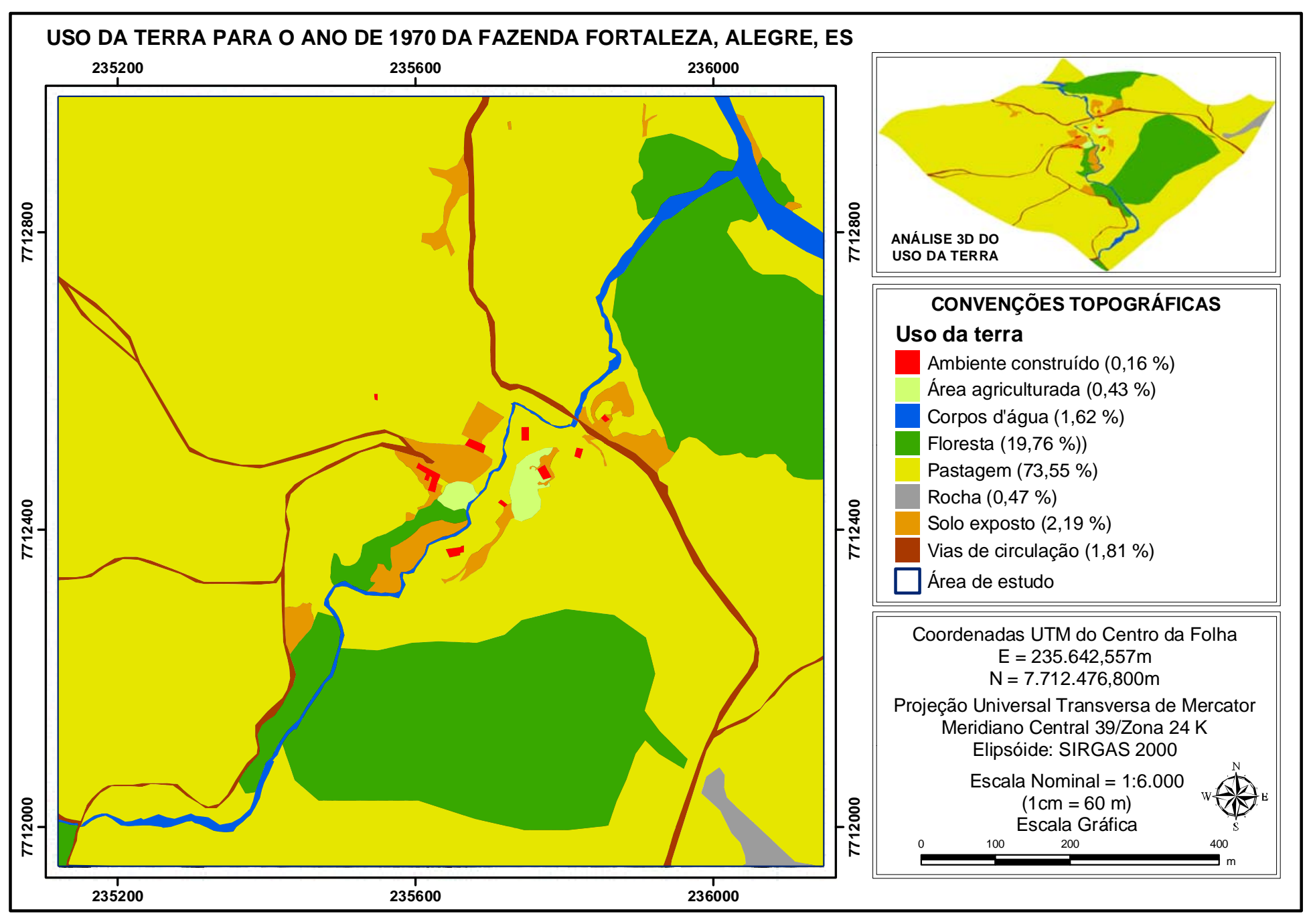

Figura 68. Uso da Terra da área de estudo da fazenda Fortaleza para o ano de 1970. 


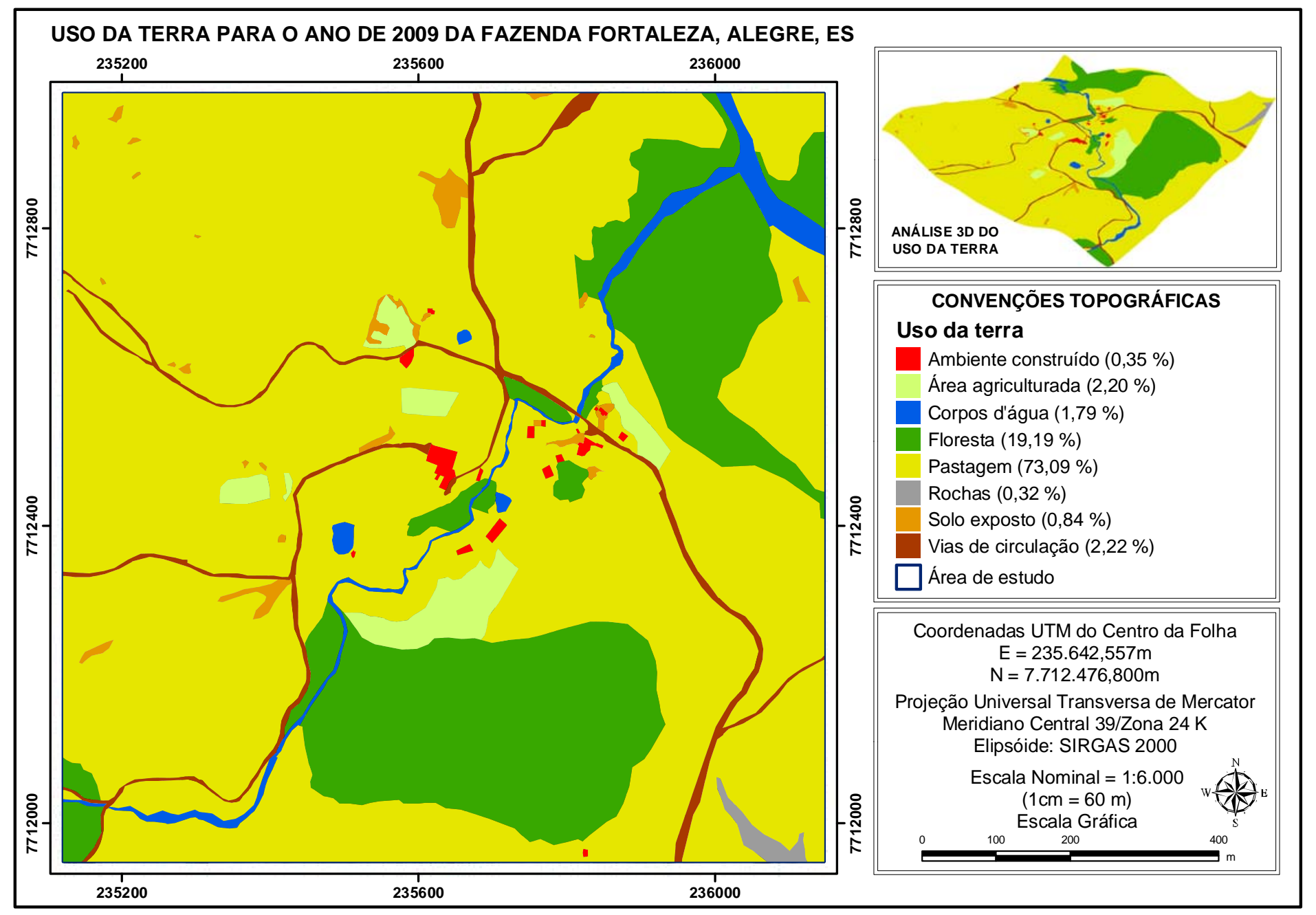

Figura 69. Uso da Terra da área de estudo da fazenda Fortaleza para o ano de 2009. 


\title{
3.3. A Sensibilidade Cultural
}

Beatriz Kühl (2010) acredita que ao se abordar questões referentes ao patrimônio cultural brasileiro, qualquer ação num bem cultural depende da apreensão que um presente histórico faz dele e as respostas que oferecem dependem das questões formuladas, que variam ao longo do tempo; a ação possui, portanto, pertinência relativa, que é algo diverso de ser impertinente. "Daí a necessidade de atuar de modo prudente, embasado numa via deduzida de princípios éticos e científicos" (KÜHL, 2010, p.29).

Nesse contexto, a partir de estudos desenvolvidos junto ao Projeto Fazendas Históricas Paulistas, Tognon (2010) afirma que a ausência de um inventário global e acessível ou de metodologias de inventário para os bens culturais é um grande problema no Brasil. Essa condição da preservação de bens culturais brasileira é amplamente discutida por Beatriz Kühl, que ao se referir aos instrumentos teóricos metodológicos e técnicos operacionais de sua conservação, ressalta que eles devem ter:

\begin{abstract}
o objetivo de fazer com que os bens sejam usufruídos no presente e transmitidos ao futuro da melhor maneira possível - com pleno respeito pelos seus aspectos materiais, documentais e de conformação, pelas suas várias estratificações e pelas próprias marcas da passagem do tempo -, sem desnaturá-los nem falseá-los, de modo que possam, de fato, continuar a exercer seu papel primordial: ser documentos fidedignos e, como tal, servir como efetivos suportes do conhecimento e da memória coletiva. Por isso, qualquer intervenção deve ser justificada do ponto de vista das razões por que se preserva (KÜHL, 2010, p.29).
\end{abstract}

Nesse sentido, considera-se que a Sensibilidade Cultural para o Ambiente Rural, através de estudo para a Fazenda Fortaleza, ofereça a oportunidade de debate do tema da gestão e conservação dos bens culturais de natureza rural na dimensão que Ihe é cabível. Assim, a possibilidade de mapear com precisão a morfologia da unidade patrimonial em sua condição existencial, retratando sua 
essência a partir de análises fenomenológicas interrelacionadas com modelo numérico, a partir de pesos estatísticos naturalmente hierarquizados, sem fragmentar o bem cultural, torna-se importante instrumento de trabalho para este tema. Tal exercício gera o mapeamento da delicadeza da percepção da obra de arte por entender que filosofia e matemática podem estar juntas na condição de finura e precisão de dados numéricos a serem utilizados em prol da gestão, da preservação e conservação dos bens culturais rurais.

É comum a utilização de zoneamento para organizar os parâmetros de intervenção em áreas que contém bens culturais, entretanto a metodologia adotada para delimitação e definição de tais limites representa desafios de diferentes categorias. Cozen (2009) apresenta estudos de mapeamento geográfico em cidades históricas inglesas com delimitação de zoneamento por áreas temáticas, buscando disponibilizar instrumentos de gestão a partir da morfologia do Bem Cultural em questão.

Aqui, o que se pretende é considerar os fatores morfológicos, respeitando a condição de unidade do objeto em estudo, em prol da sua permanência às gerações futuras, entendendo-o como bem cultural, portanto atrelado aos parâmetros de intervenção da ciência da preservação, considerando uma adequada deontologia profissional, conforme orienta Kühl (2008).

Assim retratar matematicamente o quanto está sensível um objeto de referência cultural, à sua própria permanência no meio em que está inserido, tendo em vista sua condição rural, gerou quatro mapas de Sensibilidade Cultural, para a fazenda Fortaleza, uma vez que se optou por realizar análise comparativa desta realidade para dois momentos históricos distintos. Uma para o ano de 1970, quando se acredita iniciar no Brasil as ações de reconhecimento efetivo do patrimônio rural, apesar de registros de estudos anteriores pelo IPHAN, e outra para o ano de 2009, que buscou obter dados atuais, além da geração de parâmetros de transformação do objeto neste período de aproximadamente 40 anos.

O mapeamento da Sensibilidade Cultural para o Ambiente Rural traz a possibilidade de reflexões perante as condições da fazenda, a partir de uma leitura ampla de parâmetros que permeiam por uma condição de baixa, média a alta sensibilidade do objeto - Fazenda Fortaleza. As Figuras 70 e 71 apresentam 
sobreposição do mapa de Sensibilidade Cultural, com transparência sobre a mesma localidade em foto de satélite da área de estudo, para os anos de 1970 e 2009 respectivamente. Esse recurso possibilita a visualização da condição da fazenda diante de sua própria realidade cultural. As Figuras 70 e 71 possibilitam verificar que quanto mais próximo da Casa Sede da fazenda Fortaleza, maior é a Sensibilidade do objeto aos parâmetros culturais. As ações de preservação devem, portanto, focar nesta região com maior critério e exigência conforme a ética prescrita pela ciência da conservação. Em contrapartida, os extremos da área de estudo possuem a mais baixa Sensibilidade Cultural para o Ambiente Rural, indicando demandas distintas de intervenção, conforme variam as diferentes regiões mapeadas.

Acredita-se que a setorização gerada pela Sensibilidade Cultural seja resultado da leitura matemática por região de maior incidência de fatores de elevada fragilidade cultural, apresentados pelo bem cultural em contraposição àqueles de menor fragilidade, conforme a condição deste momento histórico.

As reflexões aqui possíveis focam a condição rural do objeto, tendo sido relacionado Fatores de Fragilidade Morfológica e Cultural que compõem a unidade potencial da fazenda, entendendo-a em sua essência como se manifesta. Portanto não são contemplados critérios ou condições, outras, possíveis de se apresentarem. Trabalha-se com a realidade atual e não hipotética. Observa-se que essa condição de centralidade junto à sede da fazenda é a mesma tanto para o ano de 1970 quanto para o ano de 2009, demonstrando que a fazenda Fortaleza manteve-se praticamente inalterada nos últimos quarenta anos, quando observada a partir de mapeamento por setores com limites não definidos, realizando-se leituras por manchas que percorrem regiões de maior a menor Sensibilidade Cultural para o Ambiente Rural e ressaltando que a região de média sensibilidade acontece de maneira expressiva, conforme Figuras 70 e 71, respectivamente. Após a reclassificação da Sensibilidade Cultural é possível relacionar os parâmetros de baixa, média, alta e muito alta Sensibilidade em índices com valores numéricos definidos com limites precisos. Acredita-se que este instrumento contribua efetivamente para o auxílio do inventário e gestão responsável do patrimônio rural, uma vez que sua exatidão gera leituras preciosas de sutis alterações que representam amplas influências junto ao objeto em estudo no que se refere à sua exposição de maior ou menor sensibilidade cultural. 


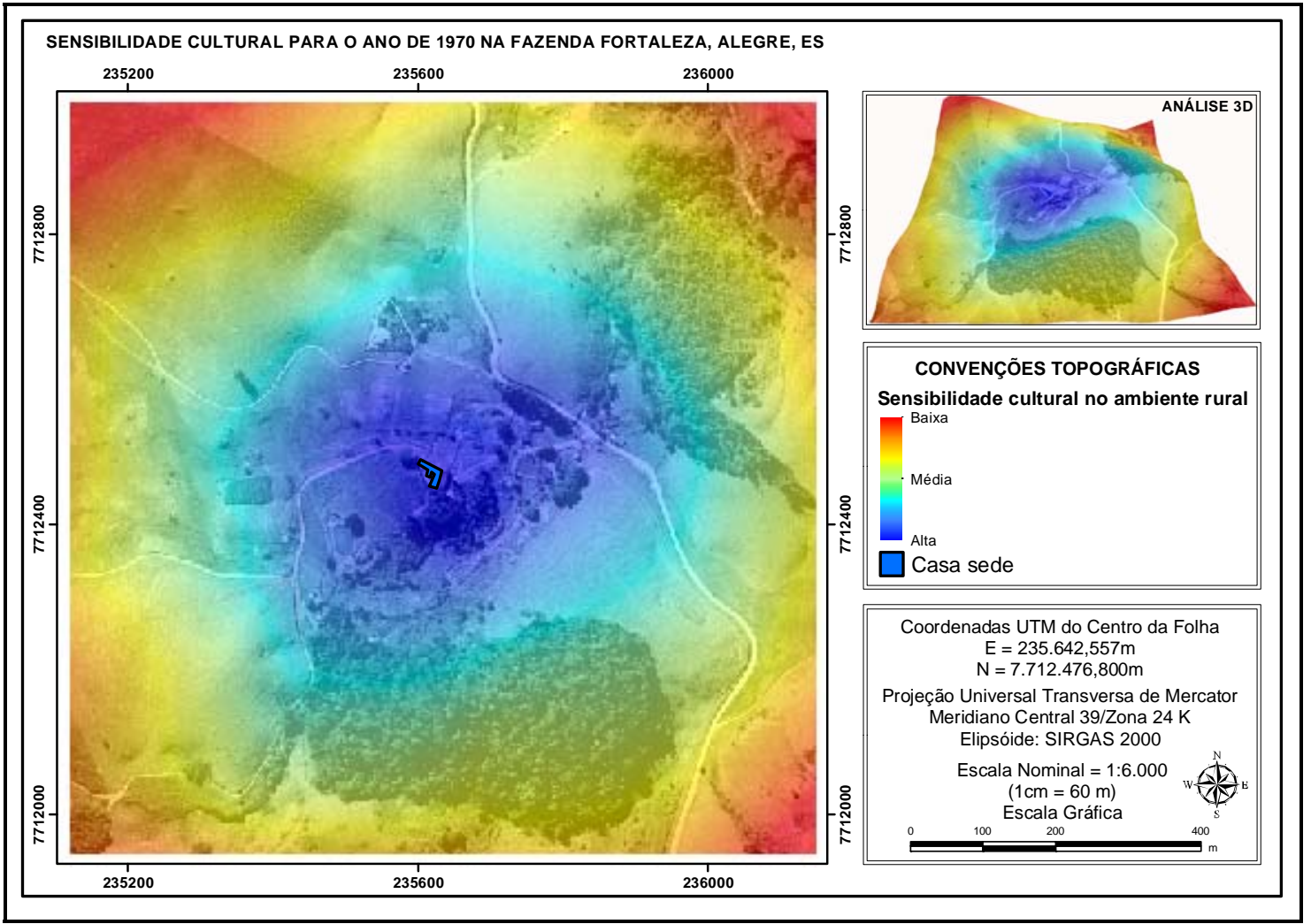

Figura 70. Sensibilidade cultural no ambiente rural para o ano de 1970 da fazenda Fortaleza, município de Alegre, ES.

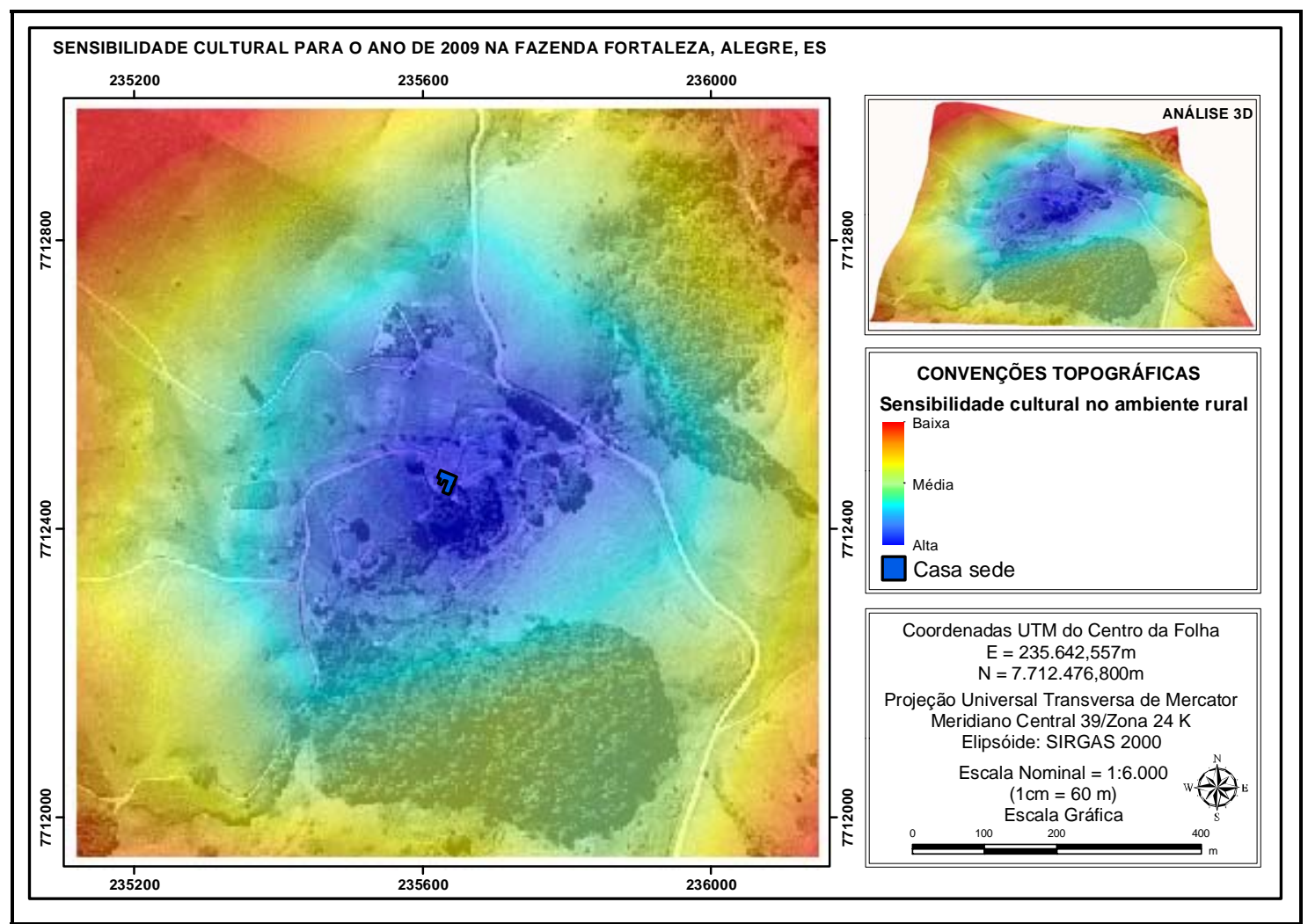

Figura 71. Sensibilidade cultural no ambiente rural para o ano de 2009, na fazenda Fortaleza, município de Alegre, ES. 
Em termos de análise macro, as Figuras 70 e 71 permitem leitura de uniformidade, mas alteram-se com a aproximação numérica, que exibe maior precisão da realidade do objeto a partir dos desafios da preservação. As Figuras 72 e 73 mapeiam o índice de Sensibilidade Cultural da fazenda Fortaleza para o ano de 1970 e 2009, respectivamente, relacionando os valores numéricos de Sensibilidade, conforme extraído para a Tabela 12 e Tabela 13, respectivamente. Para o ano de 1970, a área com índice de Sensibilidade Cultural para o Ambiente Rural - SCAR, definida como muito alta, possui área de 21,0 ha, em limite de 1,7 quilômetros, representando um total de 19,8\% de toda a área de estudo. E, SCAR alta consta de 54,3 ha e $51,2 \%$ da área total. Verifica-se que $71 \%$ da área de estudo da fazenda Fortaleza está em região de elevada SCAR, o que indica vasta extensão em situação de expressiva demanda de ações específicas se considerarem as necessidades de sua preservação. Essa realidade retrata a leitura do objeto em sua unidade como bem cultural. A fazenda não é apenas arquitetura, mas diversos elementos que a define como patrimônio rural: os caminhos, corpos d'água, pastagem, floresta, dentre outros. Cabe ainda entender que SCAR baixo, em 0,8\% da área, não significa região a ser desconsiderada, mas apenas de menor impacto cultural, perante as demandas de ação e gestão da preservação da fazenda, onde a Casa Sede é apresentada como FFMC de maior peso geoestatístico para este conjunto rural, neste momento histórico.

O índice de Sensibilidade Cultural para o Ambiente Rural - SCAR, mapeado para o ano de 2009, conforme Figura 73 e tabela 13, mostra que $72,3 \%$ da área de estudo da fazenda Fortaleza localiza-se em elevado índice de Sensibilidade Cultural SCAR, e do restante, 26,3\% possui índice intermediário de SCAR. Para 2009, essa condição destaca a importância da Fortaleza como bem cultural e de elevada preservação de sua natureza rural oitocentista. Traz ao século XXI, um patrimônio preservado com amplitude de 104,5 ha diante de um total de 106,0 ha de área relacionada como de estudo. A fazenda apresenta, portanto, excelente condição de preservação enquanto unidade rural, uma vez que o elevado índice de Sensibilidade Cultural transparece a natureza de sua existência cultural ativa, a partir de sua permanência, evidenciando-se assim a manutenção de sua unidade potencial. 


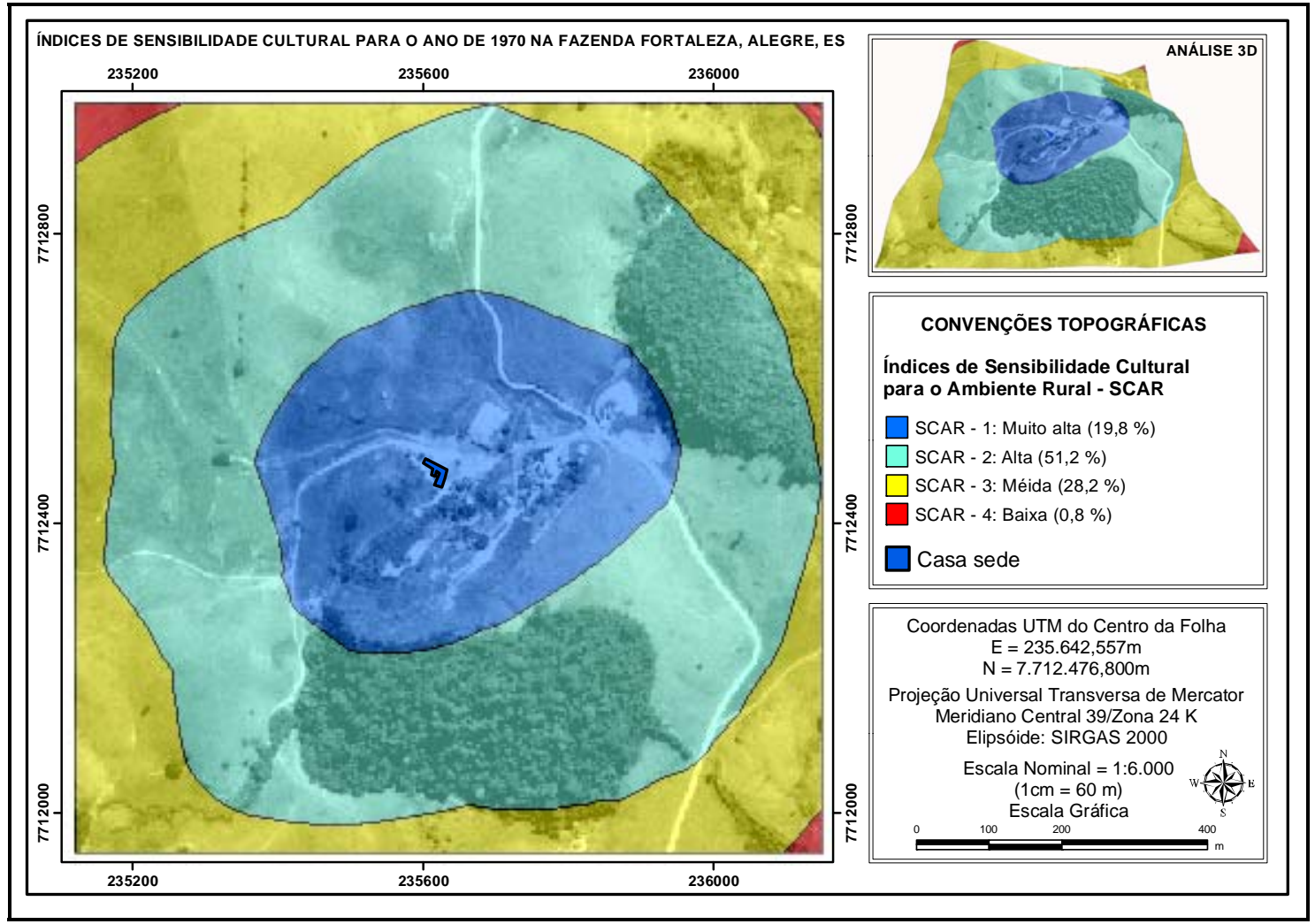

Figura 72. Índices de sensibilidade cultural no ambiente rural para o ano de 1970, na fazenda Fortaleza, município de Alegre, ES.

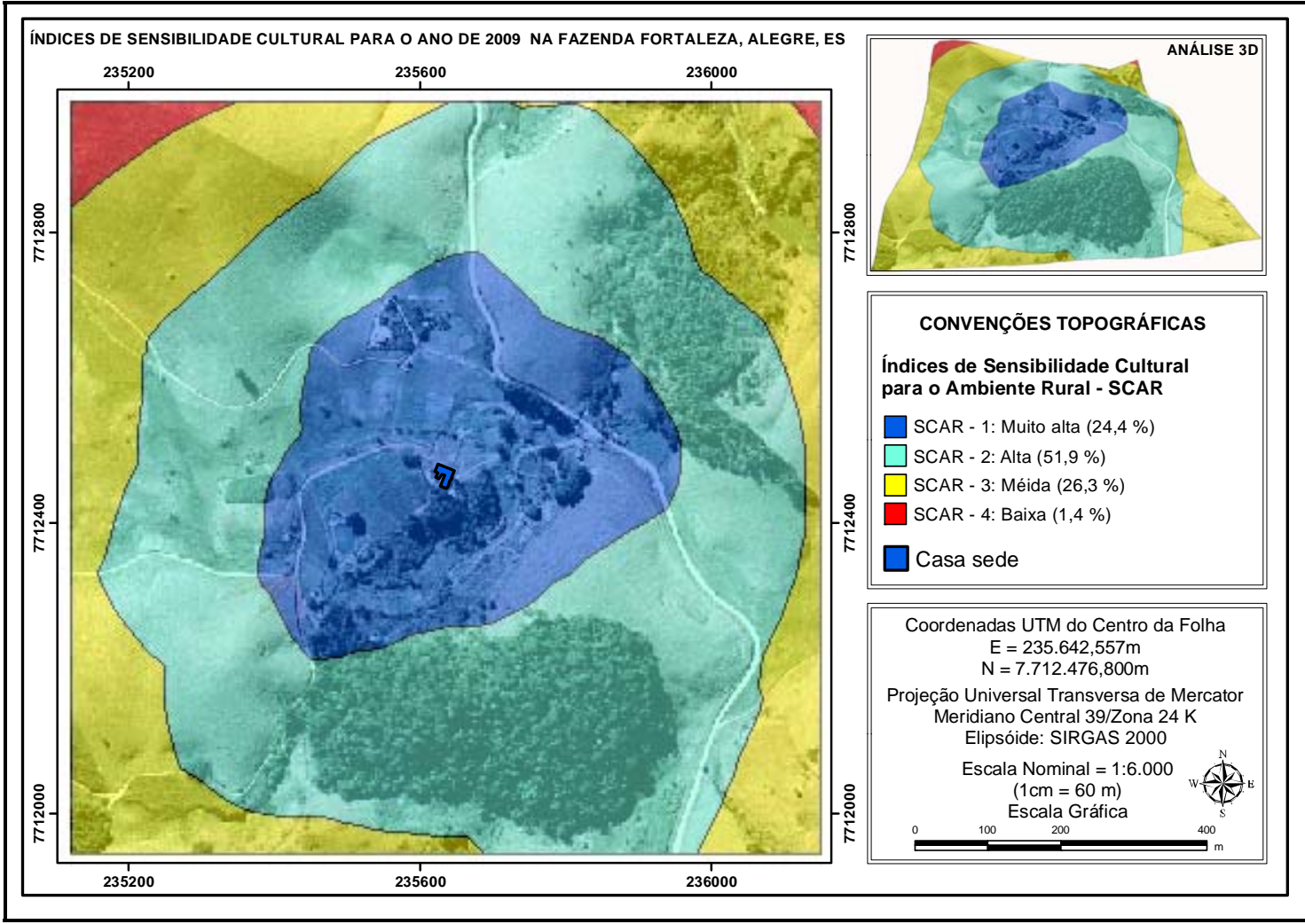

Figura 73 - Índices de sensibilidade cultural no ambiente rural para o ano de 2009, na fazenda Fortaleza, município de Alegre, ES. 
Tabela 12. Análise quantitativa dos índices de sensibilidade cultural no ambiente rural para o ano de 1970, na fazenda Fortaleza, município de Alegre, ES.

\begin{tabular}{cccc}
\hline Classe & Área (ha) & Perímetro (km) & Porcentagem (\%) \\
\hline SCAR - 1: Muito alta & 21,0 & 1,7 & 19,8 \\
SCAR - 2: Alta & 54,3 & 4,6 & 51,2 \\
SCAR - 3: Média & 29,8 & 7,1 & 28,2 \\
SCAR - 4: Baixa & 0,8 & 0,7 & 0,8 \\
Total & $\mathbf{1 0 6 , 0}$ & $\mathbf{1 4 , 1}$ & $\mathbf{1 0 0 , 0}$ \\
\hline
\end{tabular}

Tabela 13. Análise quantitativa dos índices de sensibilidade cultural no ambiente rural para o ano de 2009, na fazenda Fortaleza, município de Alegre, ES.

\begin{tabular}{cccc}
\hline Classe & Área (ha) & Perímetro (km) & Porcentagem (\%) \\
\hline SCAR - 1: Muito alta & 21,6 & 1,8 & 20,4 \\
SCAR - 2: Alta & 55,0 & 5,0 & 51,9 \\
SCAR - 3: Média & 27,9 & 6,5 & 26,3 \\
SCAR - 4: Baixa & 1,5 & 0,8 & 1,4 \\
Total & $\mathbf{1 0 6 , 0}$ & $\mathbf{1 4 , 1}$ & $\mathbf{1 0 0 , 0}$ \\
\hline
\end{tabular}

Os índices de Sensibilidade Cultural para o Ambiente Rural da fazenda Fortaleza foram gerados para os anos de 1970 e 2009 e ao se realizar análises comparativa e quantitativa desses valores, de acordo com a Tabela 14 e Figura 74, verifica-se a ampliação em $0,6 \%$ da SCAR muito alta, ampliação de 0,7\% da SCAR alta, resultando uma SCAR de 1,3\% a mais para os índices de elevada SCAR. Em contrapartida a SCAR média diminuiu em 1,9\%, e a baixa SCAR ampliou em 0,6\%. Acredita-se que esses dados numéricos retratam a redução de uma área de transição entre objeto cultural e seu entorno em potencial, mostrando a ampliação da percepção da fazenda como bem cultural em seus componentes de concepção, conforme preconiza os manuais de agricultura do século XIX, onde, por exemplo, a floresta, a formação rochosa, mesmo estando distantes da Casa Sede,fazem parte do ambiente rural, corroborando para a manutenção da unidade potencial do objeto em sua condição de bem cultural. 
Tabela 14. Análise comparativa e quantitativa dos índices de sensibilidade cultural no ambiente rural para os anos de 1970 e 2009 da fazenda Fortaleza, município de Alegre, ES.

\begin{tabular}{|c|c|c|c|c|c|}
\hline \multirow{2}{*}{ Classe } & \multicolumn{2}{|c|}{ Área (ha) } & \multicolumn{2}{|c|}{ Porcentagem (\%) } & \multirow{2}{*}{$\begin{array}{l}\text { Variação da porcentagem } \\
\text { (\%) }(2009-1970)\end{array}$} \\
\hline & 1970 & 2009 & 1970 & 2009 & \\
\hline SCAR - 1: Muito alta & 21,0 & 21,6 & 19,8 & 20,4 & 0,6 \\
\hline SCAR - 2: Alta & 54,3 & 55,0 & 51,2 & 51,9 & 0,7 \\
\hline SCAR - 3: Média & 29,8 & 27,9 & 28,2 & 26,3 & $-1,9$ \\
\hline SCAR - 4: Baixa & 0,8 & 1,5 & 0,8 & 1,4 & 0,6 \\
\hline Total & 106,0 & 106,0 & 100,0 & 100,0 & 0,0 \\
\hline
\end{tabular}

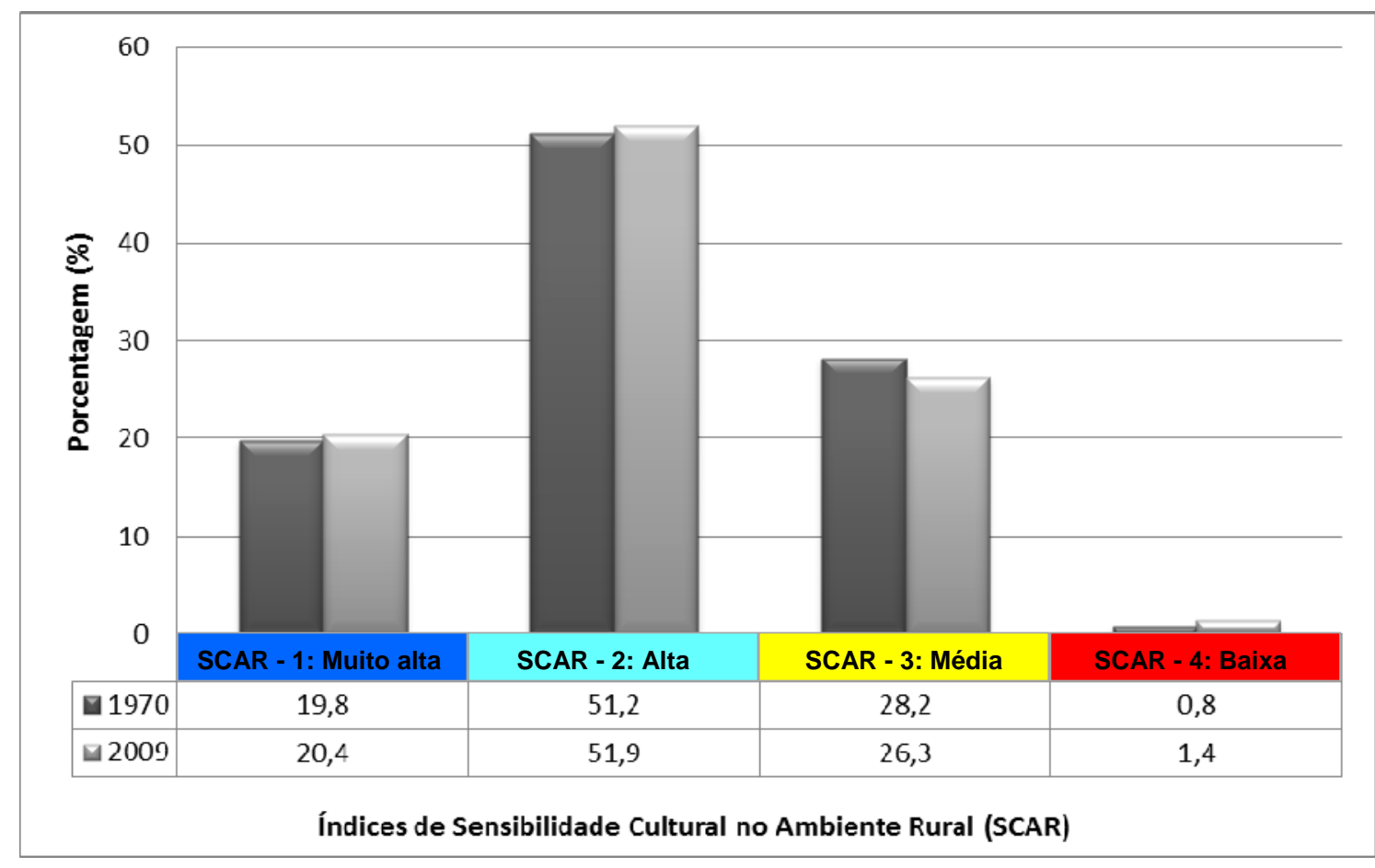

Figura 74. Comparação da análise quantitativa dos índices de sensibilidade cultural no ambiente rural para os anos de 1970 e 2009 da fazenda Fortaleza, município de Alegre, ES.

A partir das reflexões obtidas em decorrência dos estudos da Sensibilidade Cultural para o Ambiente Rural da fazenda Fortaleza, constatou-se a partir dos cálculos números relacionados à matriz pareada, do método AHP por Saaty (1977), que a Casa Sede é o Fator de Fragilidade Morfológica e Cultural de maior peso geoestatístico tanto para o ano de 1970 quanto para o ano de 2009. O peso estatístico gerado para a Casa Sede da fazenda Fortaleza foi de 0,4287 , de um total 
máximo de 1 , o que a coloca como elemento indispensável à manutenção da unidade potencial da fazenda, na condição de bem cultural. Considera-se necessária maior investigação do Fator Fragilidade Morfológica e Cultural, Casa Sede, na expectativa de ampliação das reflexões inerentes à preservação da fazenda Fortaleza para as gerações futuras.

\subsection{Fragilidade Morfológica e Cultural da arquitetura rural: a madeira na fazenda Fortaleza}

Fragilidade Morfológica e Cultural da Arquitetura Rural: O caso da Fazenda Fortaleza

A partir de estudo do Processo de Terras (1924) da fazenda Fortaleza, acredita-se tratar de uma edificação anterior a 1842 já que nesta data ocorre o primeiro registro da venda do imóvel ao Coronel Monteiro da Gama. Originalmente, a fazenda Fortaleza e fazenda Saudade possuíam terras em comum. No século XX, ocorreu a negociação das terras devido à troca de proprietários e divisão por questão de inventário a herdeiros. Atualmente, a fazenda Fortaleza não possui vínculo com a fazenda Saudade, que perdeu sua antiga sede.

A sede da Fortaleza é uma construção que possui traços típicos das residências de origem de colonização portuguesa no Brasil, onde primeiramente se levantava a estrutura de madeira e depois se colocava a cobertura, preenchendo as paredes com pau-a-pique. Com implantação em aclive, caracteriza uma construção em desnível com aproveitamento de porão alto para depósito e criação de animais (Figura 75).

Atualmente, a fazenda possui mais de 150 anos de construção e a Casa Sede apresenta poucas alterações arquitetônicas e estruturais, conforme indica pesquisa histórica e análise realizada em visita a campo. Em Nascimento, (2005) a partir do ambiente construído, pode-se conhecer qualquer coisa, seja a história de alguém que viveu no passado ou a de quem vive no presente, pois a edificação é um parâmetro de leitura não só de seu morador, mas da própria sociedade, uma vez 
que possibilita a análise de seu sistema construtivo, do requinte dos acabamentos, das escolhas e relações dos espaços que a configura, e forma de edificar em geral, indicando à cultura que a inspirou, a ocupação do território.

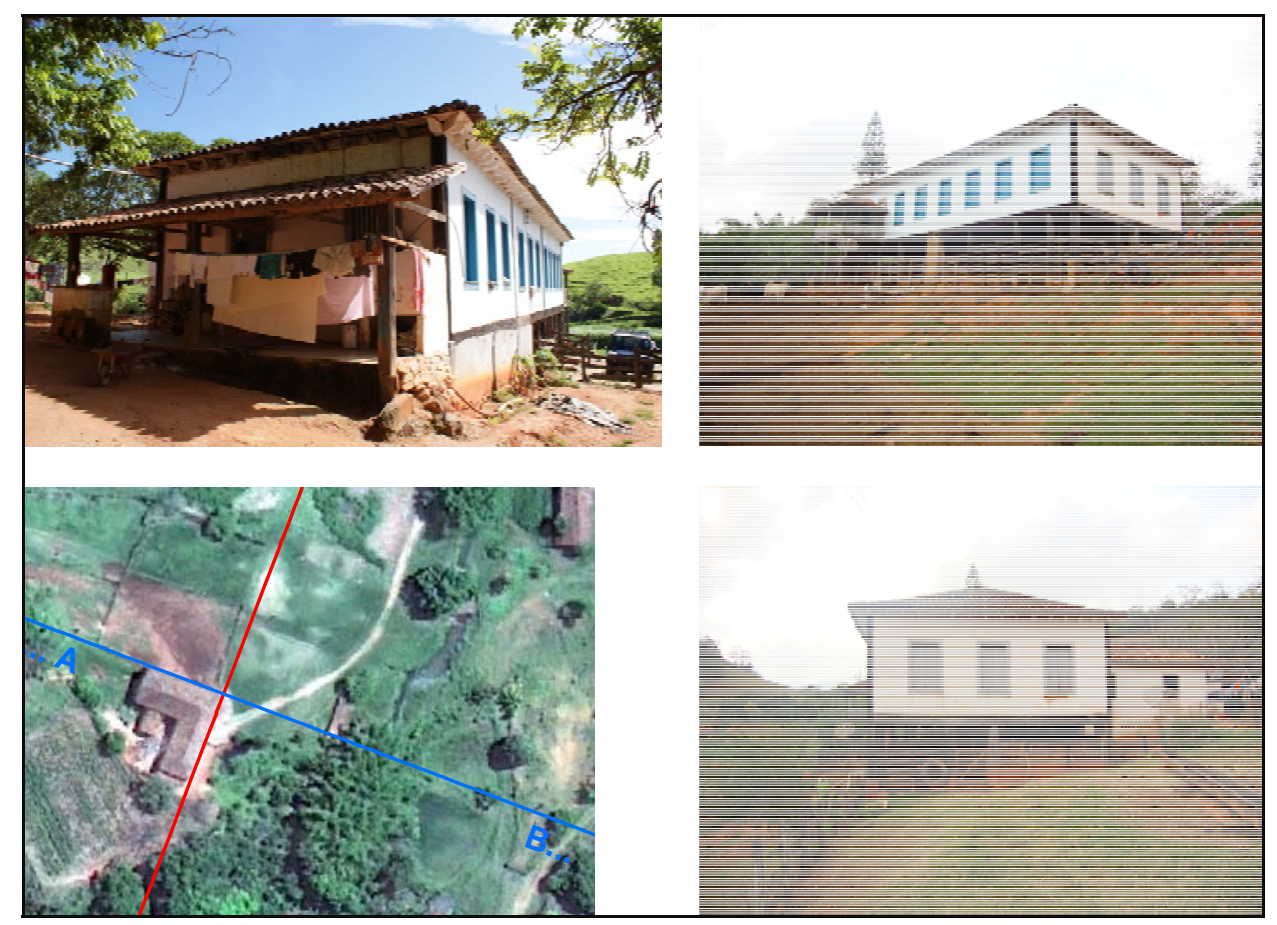

Figura 75. Casa Sede da fazenda Fortaleza

A partir do inventário de 1890 da fazenda Fortaleza, amplia-se a compreensão de como os seus proprietários viviam, tanto considerando os costumes, como a condição econômica. Dentre os bens relacionados constam sofás, mesa com pedra mármore, marquesas, catres, lavatórios, camas francesas, mesas grandes e pequenas, armários, cômoda, lavatório de pedra, armário para medicamentos, armário para roupas, louça, vidros, relógio de parede, talheres, relógio, dentre outros utensílios domésticos, como consta no Processo de Terras da Fortaleza (INSTITUTO DE DEFESA AGROPECUÁRIA E FLORESTAL DO ESPÍRITO SANTO, 1924). As sedes das fazendas oitocentistas, além da casa de moradia, reuniam também o complexo de edificações ligadas, direta ou indiretamente, à sua produção e custeio. Constam paióis, armazéns, cavalariças, senzalas, hospital, etc. As chamadas fábricas completavam o quadro: engenho de serrar, moinho de milho, engenho de mandioca e engenho de pilões (WERNECK, 1985, p.29). 
Conforme Processo de Terras (INSTITUTO DE DEFESA AGROPECUÁRIA E FLORESTAL DO ESPÍRITO SANTO, 1924), em 1890 a fazenda Fortaleza era formada por cafezais frutíferos, matas virgens, capoeiras, pastos, casa de sobrado para moradia, engenho de pilões, engenho de cana, paiol, tulha, casa dos exescravos, moinho, ceva para porcos com casa, seis ranchos cobertos de telha na lavoura. Pode-se observar que apresentava programa, conforme orienta os manuais de agricultura utilizados no século XIX. O levantamento físico arquitetônico da Casa Sede da fazenda Fortaleza evidencia a implantação em aclive. A maioria dos componentes edificados que compuseram o programa da fazenda quando de sua origem, já não existem mais; o curral ocupa uma nova área e forma de divisão diferente do século XIX, conforme registra a planta de situação da fazenda. O ambiente construído foi transformado, tendo elementos e edificações eliminadas ou substituídas (Figura 76), como é o caso do chiqueiro e do paiol. Já a Casa Sede, ou casa de morada, teve como principal alteração a mudança de localização do alpendre, e construção nos anos de 1960, aproximadamente, de uma ampliação contígua a casa na fachada posterior.

De acordo com Werneck (1878, p.3), após a execução das instalações provisórias, que antecedem a planta da fazenda, deverá ser providenciado o canal que trará a água para mover as máquinas do complexo rural; "o rego deve ser feito com perfeição e cuidado, observando-se bem o nivelamento, porquanto é na boa execução do traço primitivo que se estabelece a permanência e segurança das obras desse gênero". O Barão de Paty destaca ainda que depois de tomada as providências quanto à água, deve-se antes de tudo fazer o engenho de serrar madeira, o qual reduzirá pela metade o custo das obras da nova fazenda, facilitando todos os trabalhos e poupando muitos braços e despesas. O moinho para a preparação do fubá e o engenho para o fabrico da farinha devem ainda ser providenciados.

A estas obras deve suceder a construção das máquinas que forem reclamadas pela natureza da cultura a que o lavrador se dedicar, e a das habitações do pessoal livre e escravo, devendo estas serem voltadas para o poente ou para o nascente, divididas em compartimentos de vinte e quatro palmos quadrados, e tendo na frente uma varanda de oito palmos de largura (WERNECK, 1878, p.4). 


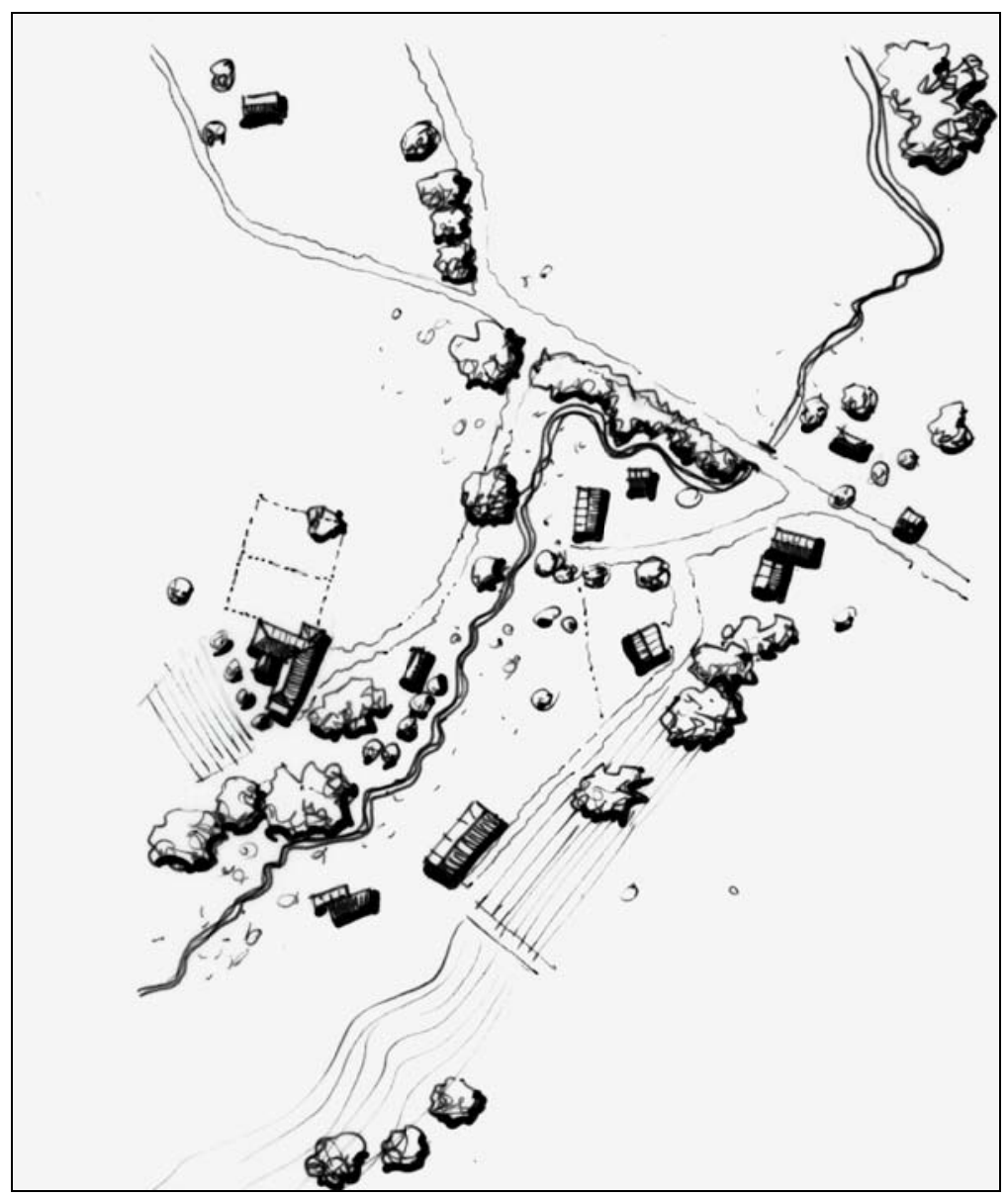

Figura 76. Planta de situação da Casa Sede da fazenda Fortaleza

A partir da proposta para um adequado planejamento de uma fazenda, Werneck (1878, p.4) afirma que apesar da arquitetura rural não acontecer com regras fixas, "é fora de dúvida que tal ou qual elegância não é incompatível com a economia que deve presidir a todas as construções que houveram de ser levantadas em uma fazenda". Ele lembra ainda que as prescrições de higiene devem ser adotadas e elas não encarecem as obras de construção da fazenda, "assim a umidade sendo um dos inconvenientes do nosso clima, é forçoso que o lavrador procure situar as habitações no lugar mais seco e enxuto do estabelecimento". No levantamento cadastral realizado em 2010, registram-se os dois pavimentos da Casa Sede que possui planta em "L". A Casa Sede, parcialmente assobrada, possui curral e depósito de tralhas no pavimento inferior e no térreo, uma cozinha, um refeitório, duas dispensas, uma lavanderia, um lavatório, dois banheiros, uma sala de jantar, quatro salas, sendo uma sala de estar e outra de visitas, um salão, um cômodo de circulação, uma varanda, um alpendre e oito quartos (Figuras, 77 e 78). 


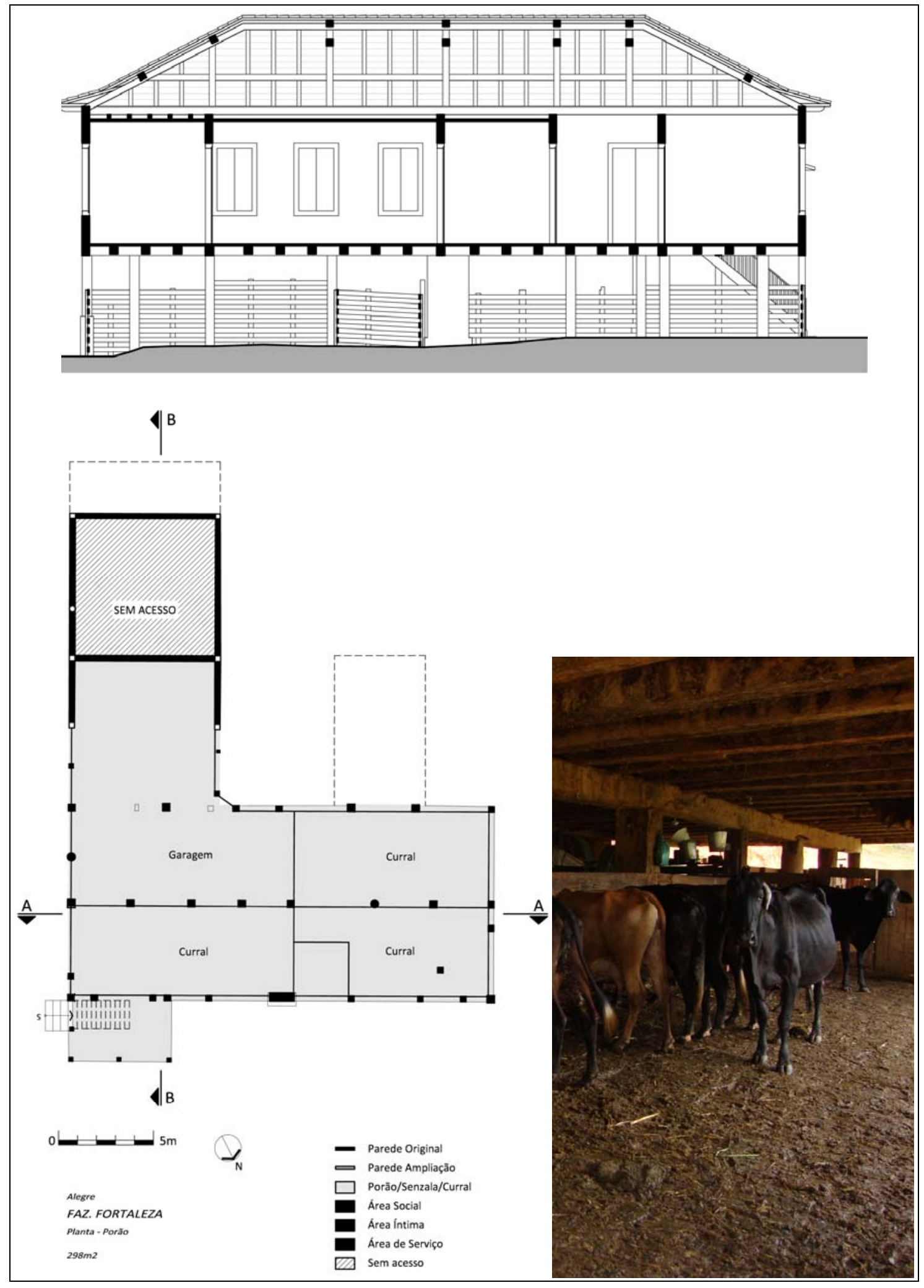

Figura 77. Corte transversal planta do pavimento inferior da Casa Sede da Fazenda Fortaleza. Desenho Mateus Rosada, 2012. 


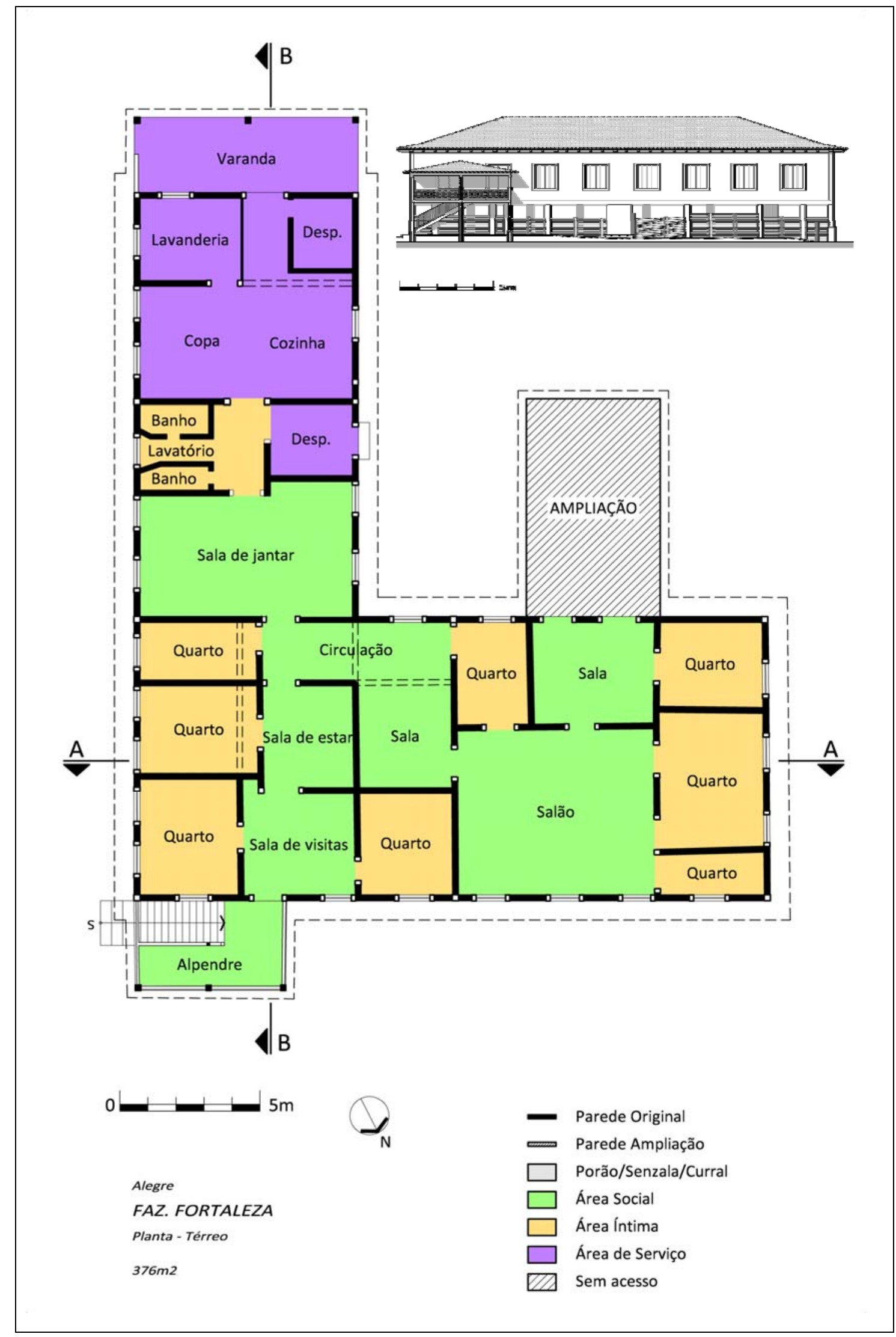

Figura 78. Planta baixa e fachada frontal da Casa Sede da fazenda Fortaleza, Alegre (ES). Desenho Mateus Rosada, 2012. 
O levantamento da cobertura (Figura 79) registra a cumeeira do setor frontal (sala) da Casa Sede da fazenda Fortaleza em cota altimétrica mais elevada que a do setor lateral (cozinha), uma vez que estas se ligam por meio do espigão localizado entre a cumeeira frontal e a água mestra junto a da fachada lateral. As quedas d'água possuem quatro sentidos de indicações diferentes, e devido ao contra-efeito ${ }^{13}$ do galbo, possui beiral de $75 \mathrm{~cm}$, sendo $50 \mathrm{~cm}$ de cachorros e mais $25 \mathrm{~cm}$ de telha. A estrutura do telhado conta com três tesouras do tipo cangalha e duas no estilo asnas.

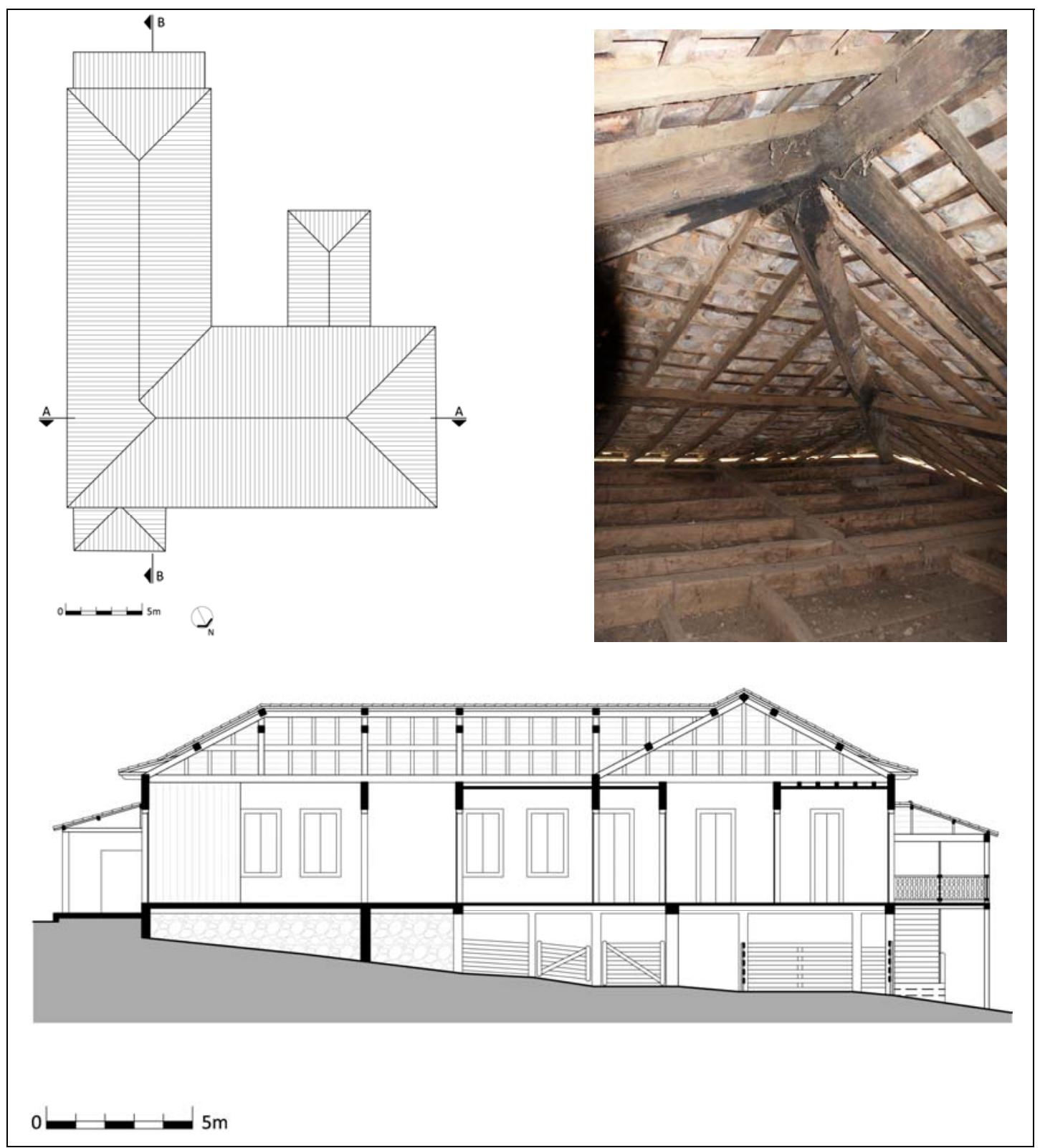

Figura 79. Telhado e corte longitudinal da Casa Sede da Fazenda Fortaleza. Desenho Mateus Rosada, 2012.

\footnotetext{
${ }^{13}$ Mudança de inclinação do telhado nas suas extremidades
} 
Nas cangalhas, o elemento estrutural denominado perna baixa, apresentou dimensões da seção transversal semelhante às do frechal, com dimensão média de $20 \times 25 \mathrm{~cm}$, e os elementos estruturais denominados pernas e a linha alta apresentaram dimensões da seção transversal média de 12×20 cm. Já a cumeeira e os espigões apresentaram dimensões de seção transversal de $18 \times 18 \mathrm{~cm}$. No encontro das partes lateral e frontal da casa, surge um ângulo diedro reentrante, chamado de rincão ou calha. O espigão que é responsável pelo suporte neste cruzamento apresenta dimensões de seção transversal igual a da cumeeira.

O telhado do setor lateral conta com o apoio de quatro partes denominadas asnas, cuja dimensão é a mesma do setor frontal. A asna sem pendural é um reforço estrutural para a cangalha no setor frontal, já no setor lateral, é apenas a cangalha que suporta a estrutura do telhado, descarregando a carga do telhado deste setor no frechal. O alpendre é todo composto por madeira, já a alvenaria da casa sede é tradicionalmente em pau-a-pique, conforme a Figura 80.

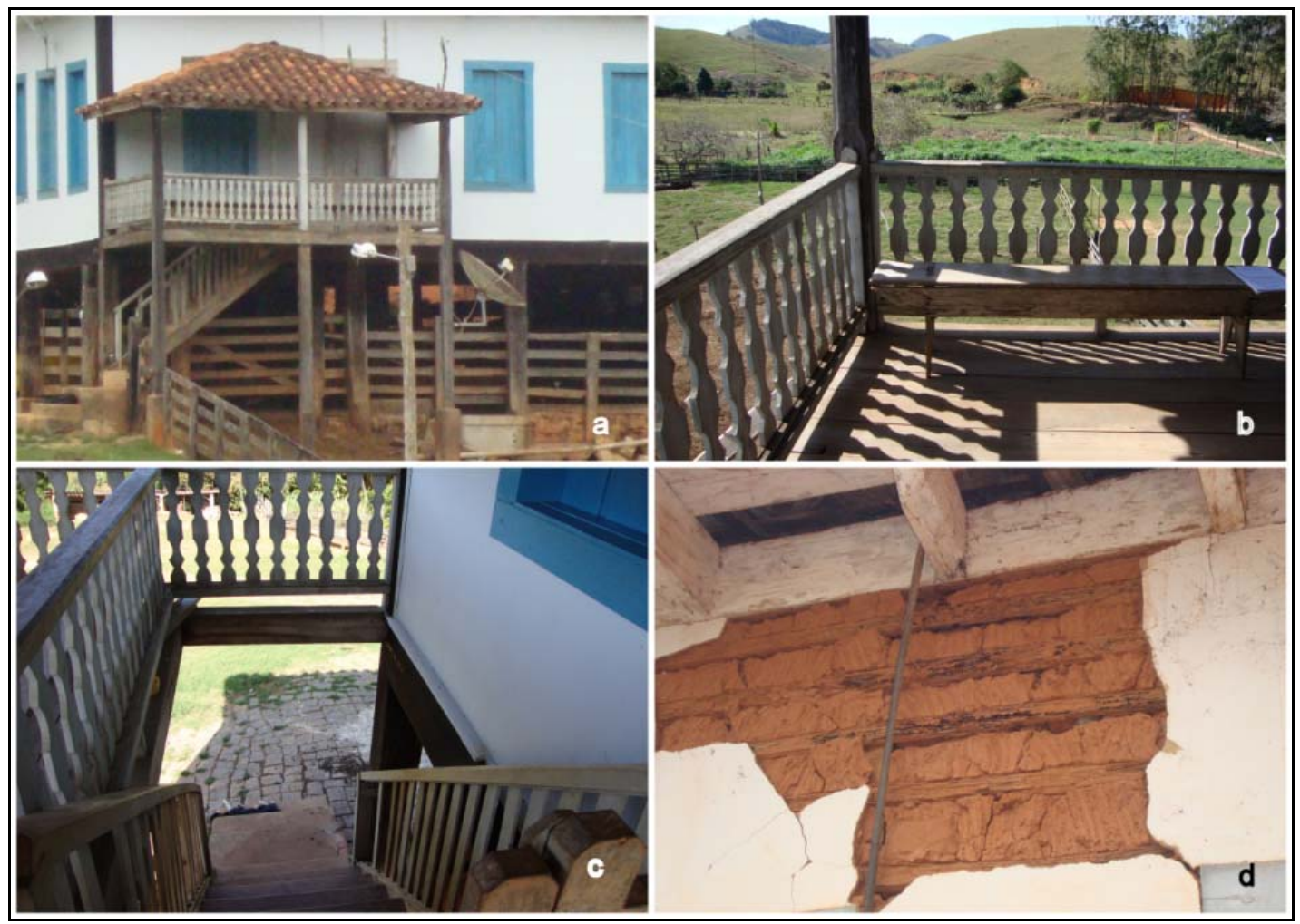

Figura 80. Sistema Construtivo da Casa Sede, fazenda Fortaleza. 
O piso tabuado corrido, de acordo com a Figura 80b, possui encaixes do tipo macho e fêmea com tábua de $30 \mathrm{~cm}$ de largura e $3 \mathrm{~cm}$ de espessura em média. A peça do piso superdimensionada possui maior inércia, e consequentemente, uma maior resistência quando solicitada ao momento fletor, ocasionando diminuição da probabilidade da peça sofrer flexão.

Os forros foram identificados como saia e camisa e as janelas e portas são todas em madeira do tipo calha, retangulares e com altura semelhante de aproximadamente 1,15 metros, se destacando perante a escala arquitetônica do edifício. A Casa Sede é composta por doze esteios estruturais, cujas peças seguem desde o frechal até a fundação e sete peças de madeira com altura do pé direito do pavimento inferior, onde funciona o curral. As medidas da seção transversal das peças são variadas, mas a seção média é cerca de $30 \times 30 \mathrm{~cm}^{2}$.

Observando o pavimento inferior (porão alto) (Figura 80), nota-se que possui umas das áreas que mais utiliza a madeira em relação ao complexo estrutural da Casa Sede. Os pilares inferiores que dão apoio aos baldrames e ao barroteamento, na qual sustentam o piso, e até mesmo a cerca que define os limites do curral, são de madeira, provavelmente da mata atlântica extraídas na região, conforme Figura 81. O porão alto consta de 25 pilares que estruturam a Casa Sede, sendo que cada um tem e seção transversal média de aproximadamente $34 \times 36 \mathrm{~cm}$.

Os baldrames e barrotes somam um total de doze peças robustas, algumas peças chegam a ter até 12 metros de comprimento, $40 \mathrm{~cm}$ de altura e $35 \mathrm{~cm}$ de largura. O barroteamento principal possui cinco peças com dimensões semelhantes a dos baldrames, já os barrotes secundários somam 31 peças robustas com seção transversal de até $45 \times 30 \mathrm{~cm}$.

O Barão Paty de Alferes, em suas memórias para a fundação de uma fazenda, disponibiliza preciosas informações sobre as espécies de madeira e sua relação com a qualidade da terra e destino adequado para uso nas edificações. Tais orientações para aplicação da madeira na construção civil se ampliam para além do universo rural, uma vez que representa tradicionalmente importante material utilizado na arquitetura brasileira em seus diferentes componentes.

Grande é sem dúvida, a pratica que um hábil fazendeiro deve ter para possuir cabal conhecimento, e conhecer ao primeiro golpe de vista toda essa diversidade de madeiras de que é enriquecido o nosso solo, coberto ainda pelas matas virgens. 
[...] o conhecimento Ihe vem, já pela folha, pela casca, pela configuração dos galhos, e já pelo cheiro ou cor do cerne, se está à árvore seca (WERNECK, 1878, p.15).

O autor classifica as madeiras adequadas para obras, conforme disponibilidade da época. Inicia a especificação pelas espécies utilizadas em esteios, organizadas em primeira e segunda qualidade. Ele especifica as espécies conforme nome popular utilizado no século XIX, para as rodas tocadas por águas e máquinas de uma fazenda oitocentista, e destaca ainda a madeira indicada para telhados, forros, vãos, dentre outras demandas de acordo com Tabela 15.

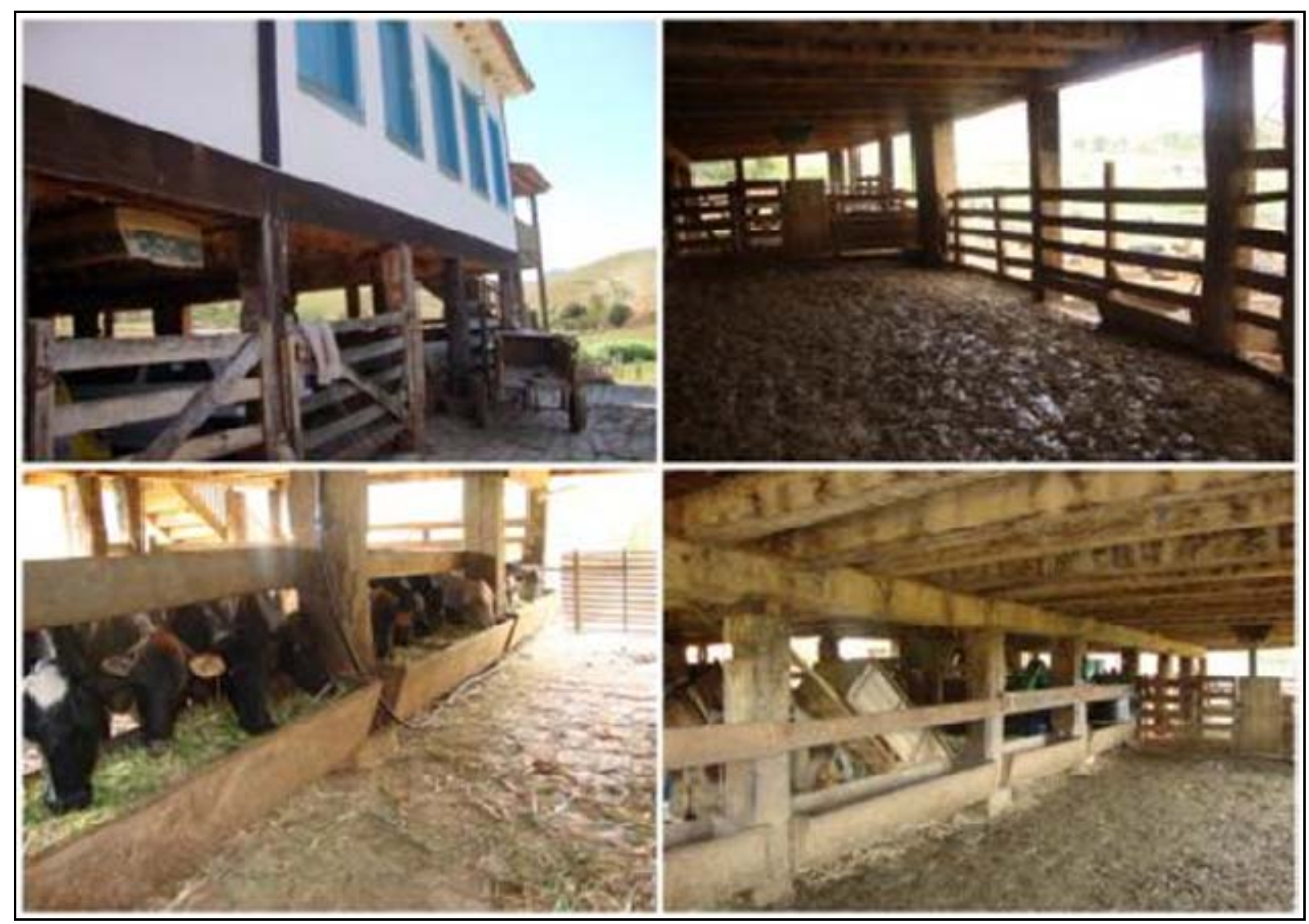

Figura 81. Piso inferior da Casa Sede 
Tabela 15. Espécies de madeiras para uso em edificação

\begin{tabular}{|c|c|c|}
\hline Uso indicado & $\begin{array}{l}\text { Espécie de madeira } \\
\text { Primeira classe }\end{array}$ & Observação \\
\hline \multirow[t]{2}{*}{ Esteios } & $\begin{array}{l}\text { jacarandá-tan, a guaraúna parda, o } \\
\text { ipé-merim, a Maria preta, o pão ferro, } \\
\text { o Sobrasil, o Assafrás, a Canela } \\
\text { preta, o Sucupira }\end{array}$ & \\
\hline & $\begin{array}{l}\text { como segunda opção: } \\
\text { maçaranduba vermelha, a peroba, o } \\
\text { óleo vermelho, a arucurana, o negro- } \\
\text { mina, o ipé-assé a guaraúna preta }\end{array}$ & \\
\hline Uso aéreo - & $\begin{array}{l}\text { guaraçahi, do cataguá, da judiahiba, } \\
\text { do angelim amargoso, do angelim } \\
\text { doce, do tinta, do óleo copahiba, do } \\
\text { óleo jatahy, da carne de vaca, do } \\
\text { guarabú, da guarapiapunha, da } \\
\text { sapucaia, da merindiba, da canela, } \\
\text { do milho cozido }\end{array}$ & $\begin{array}{l}\text { Secar a madeira debaixo } \\
\text { da cobertura enxuta. } \\
\text { Deve-se ter } \\
\text { principalmente na } \\
\text { madeira branca, todo o } \\
\text { cuidado em fazer o seu } \\
\text { corte no minguante da } \\
\text { lua, e, se possível for, de } \\
\text { junho até princípios de } \\
\text { setembro. }\end{array}$ \\
\hline Portadas & $\begin{array}{l}\text { Cataguá (magaló, pereira), de } \\
\text { guarapiapunha, de cedro, de } \\
\text { arucurana, de cangerana, e de canla } \\
\text { do brejo }\end{array}$ & $\begin{array}{l}\text { Estas madeiras têm a a } \\
\text { vantagem de ser macias, } \\
\text { receber facilmente o } \\
\text { prego e de não estalar } \\
\text { com o sol. }\end{array}$ \\
\hline Portas & $\begin{array}{l}\text { o vinhatico, o cedro, o loiro, a } \\
\text { cangeraa }\end{array}$ & $\begin{array}{l}\text { São leves e de fácil } \\
\text { trabalho. }\end{array}$ \\
\hline $\begin{array}{l}\text { Taboado de } \\
\text { assoalho }\end{array}$ & $\begin{array}{l}\text { vinhático, o cedro, o vinhático- } \\
\text { cabeleira, e loiro, o tapinhuan, a } \\
\text { becuhyba a cangerana, a arucurana, } \\
\text { a peroba, o pau-cravo, o sucupira, a } \\
\text { canela preta, a tymboyba e o } \\
\text { angelim amargoso. }\end{array}$ & \\
\hline Maquinismo & $\begin{array}{l}\text { óleo vermelho, do jacarandá-tan e } \\
\text { roxo, do sucupira, da guarapiapunha } \\
\text { e do óleo parnahyba }\end{array}$ & \\
\hline \multirow[t]{2}{*}{ Rodas d'água } & $\begin{array}{l}\text { o tapinhuan, o sucupira, a guarauna, } \\
\text { o óleo vermelho, a peroba }\end{array}$ & \\
\hline & $\begin{array}{l}\text { como segunda opção: o louro } \\
\text { preto, a merindiba, o pau-cravo, o } \\
\text { cedro, o cataguá }\end{array}$ & \\
\hline
\end{tabular}


Tais orientações, em termos estruturais, esclarecem que as espécies indicadas para esteios, são por ele entendidas como resistentes à compressão e aquelas para tabuado de assoalho, boas para flexão, por exemplo.

Observando a Figura 82, que representa a área externa que envolve a situação atual da fazenda, é possível visualizar a quantidade expressiva de elementos em madeira que constitui a Casa Sede. Entretanto para identificar as espécies utilizadas deve-se considerar a identificação botânica da madeira, que conforme Chimelo (2007), permite o acesso às suas propriedades, geralmente disponíveis em livros ou banco de dados, o que propicia um melhor conhecimento e aplicação do material. Assim, a utilização correta das espécies de madeira, depende de procedimentos que garantam a adequada identificação das mesmas.

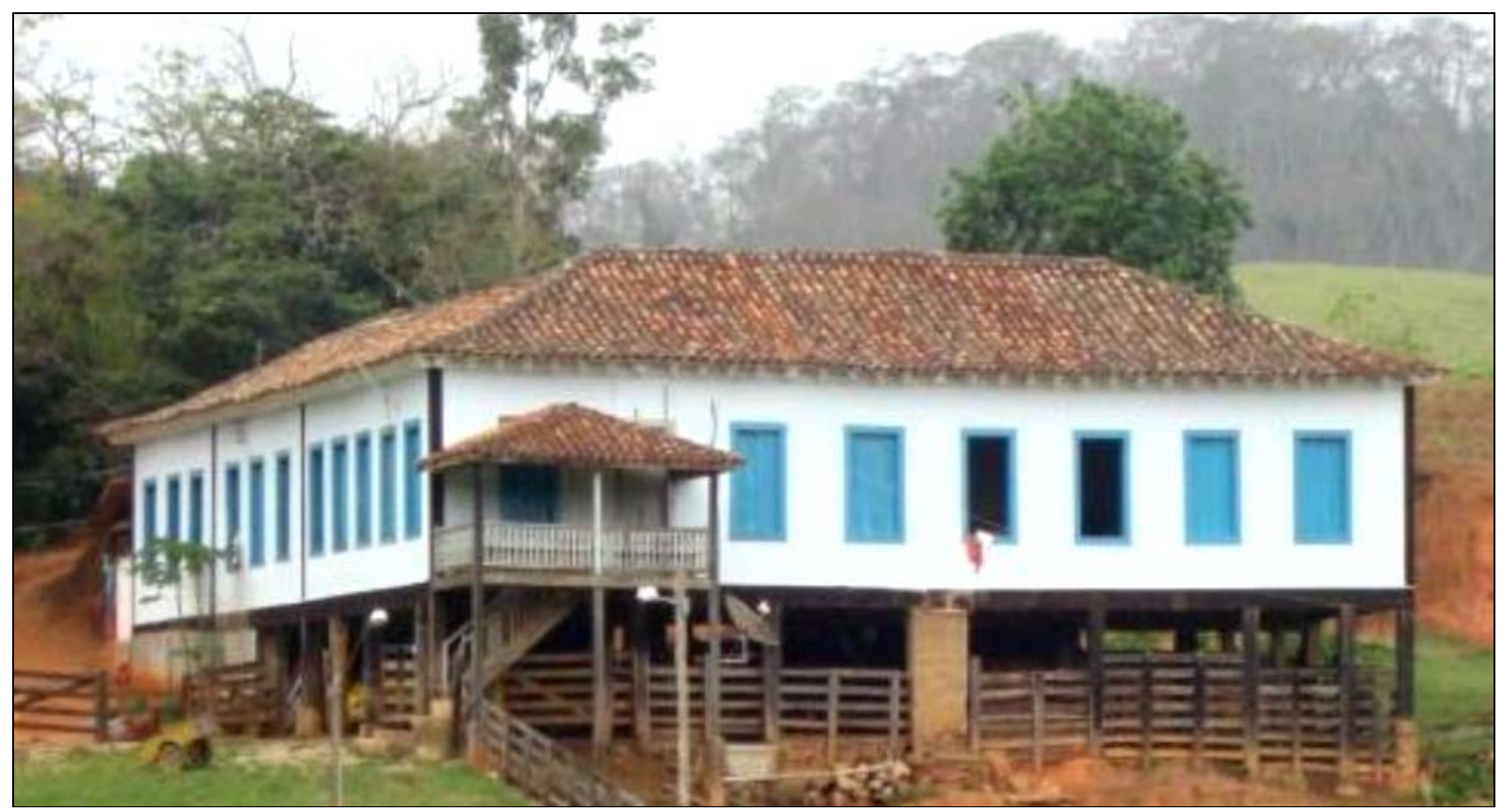

Figura 82. Casa Sede da fazenda Fortaleza, Alegre, ES.

Para conhecer a madeira de uma árvore, segundo Zenid e Ceccantini (2007), devem-se identificar suas características morfológicas, que são a casca, flores, frutos e folhas. Quando se trabalha com madeira já serrada, essas características são eliminadas, existindo a anatomia do lenho como dado para a identificação da madeira. Nos estudos anatômicos de identificação de madeiras, são utilizadas duas abordagens distintas, a macroscópica e a microscópica.

$\mathrm{Na}$ identificação macroscópica são observadas características que requerem pouco ou nenhum aumento. Tais características são reunidas em dois grupos: as 
organolépticas e as anatômicas. As características organolépticas ou sensoriais englobam a cor, o odor, o sabor, o brilho a textura e a grã (ZENID E CECCANTINI, 2007). A cor, de acordo com Costa (2001), é derivada de substâncias químicas presentes no tronco. A intensidade da coloração varia do bege claro ao marrom escuro, quase preto. Existem ainda madeiras amarelas, avermelhadas e alaranjadas. A cor tende a alterar-se com o passar do tempo, escurecendo devido à oxidação causada principalmente pela luz.

O odor é uma característica que tende a definir seu uso. As peças de madeira muito antigas podem perder parcialmente o odor, mas eventualmente este pode ser acentuado se a madeira for umedecida. O odor da madeira é classificado como indistinto ou distinto, sendo distinto, ele pode ser agradável, desagradável ou característico (COSTA, 2001). O sabor pode ser classificado como amargo, picante e adocicado. Tal característica só deve ser avaliada se o observador tiver certeza de que a madeira não recebeu nenhum tipo de tratamento químico (ZENID E CECCANTINI, 2007). O brilho é a capacidade da madeira de refletir a luz; tal característica está associada com raios, e é mais bem visto no plano radial da anatomia da madeira (COSTA, 2001).

A textura é uma característica relacionada à dimensão e organização dos elementos celulares que compõem a madeira. Pode ser: fina, média, grossa (ZENID E CECCANTINI, 2007). Já as características anatômicas macroscópicas, de acordo com Costa (2001), são aquelas observáveis a olho nu ou com uma lupa de 10 aumentos, após o polimento da superfície da madeira com uma faca bem afiada. A identificação das características do tecido lenhoso está ligada à forma, tamanho ou distribuição dos elementos celulares, que são os vasos, o parênquima axial e o parênquima radial.

Os vasos, quando são vistos cortados transversalmente, aparecem na forma de orifícios de formato circular a elíptico, sendo denominados poros. Diversas características dos vasos podem ser úteis para a identificação de madeiras: visibilidade (distinto a olho nu, distinto sob lente, indistinto sob lente), diâmetro tangencial (pequenos, médios e grandes) e frequência (muito pouco, pouco, numerosos e muito numerosos). Os vasos podem ser classificados quanto à porosidade (em anel ou difusa), quanto ao arranjo (tangencial, radial, dendrítico), quanto à obstrução (desobstruídos, obstruídos por inclusões, obstruídos por tilos) e 
quanto ao agrupamento, solitários, múltiplos e em cachos (COSTA, 2001), conforme ilustrado pela Figura 83.

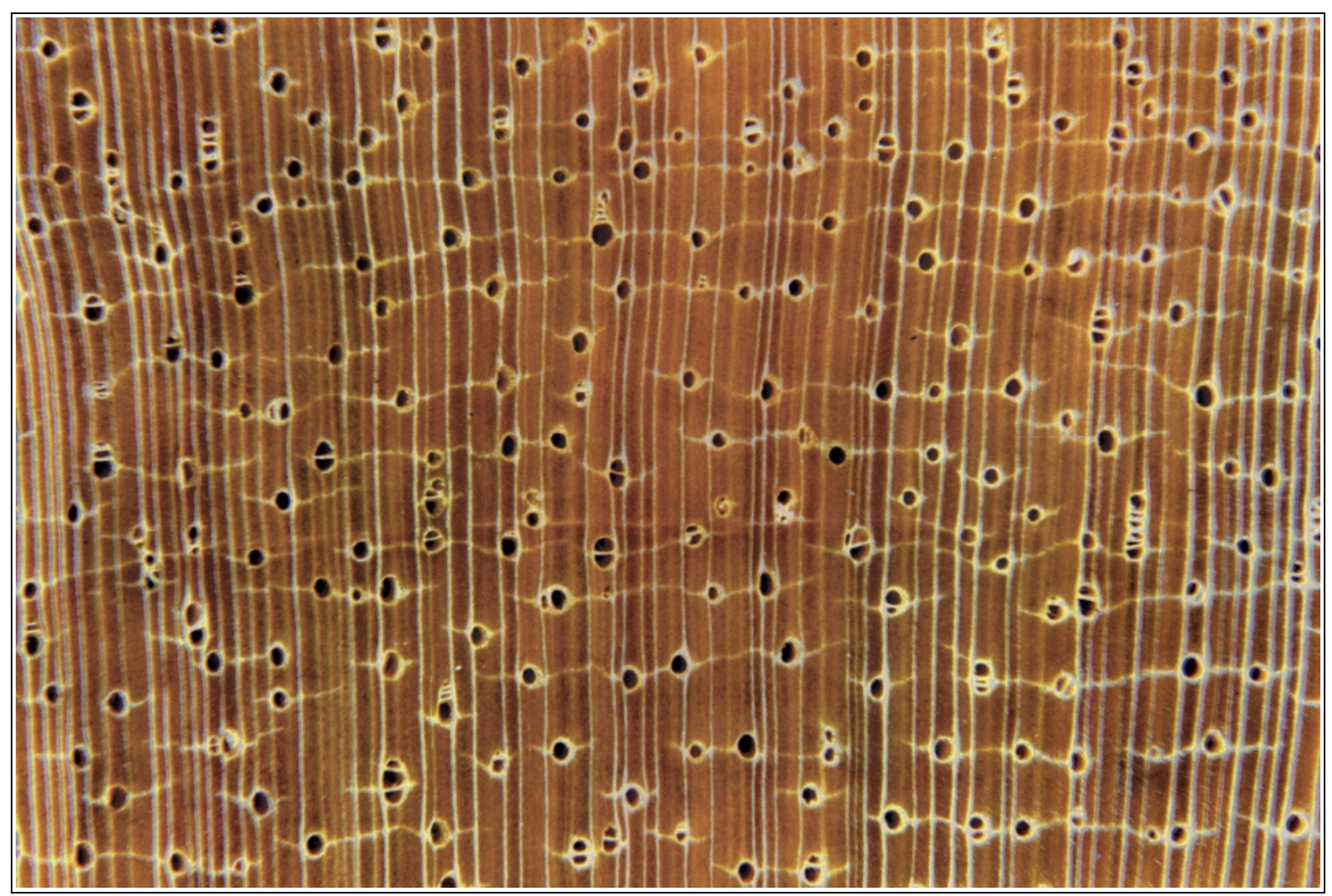

Figura 83. Identificação de madeira pelo exame Macroscópico. Disponível em <www.ipt.br>

O parênquima radial, quando presente, pode assumir diversas configurações distintas, o que permite sua classificação conforme o desenho formado. De acordo com Costa (2001), os parênquimas radiais são feixes de células alongados, formados por células dispostas horizontalmente, orientando-se da medula a periferia da árvore. Podem ser distintos a olho nu ou podem ser distintos por lente.

$\mathrm{Na}$ identificação microscópica, segundo Zenid e Ceccantini (2007), devem ser observadas as características dos tecidos como: vasos, parênquima axial e radial das células constituintes do lenho, em que ambas não são distintas sem o uso de microscópio, tais como as pontuações, a composição celular dos raios, a presença de cristais e a ornamentação da parede celular. Quanto à composição celular dos raios, quando é constituída por apenas um tipo de célula, são homogêneos, e são geralmente compostos por células parenquimáticas. Os raios formados por dois ou mais tipos de células são os heterogêneos, geralmente raios com células de 
parênquima e traqueóides radiais. Os raios, dependendo das espécies, podem sofrer variações quanto ao tamanho; raios com apenas uma célula de espessura são uniformes e raios com três ou mais células de espessura são chamados de fusiforme (ZENID E CECCANTINI, 2007).

$\mathrm{Na}$ fazenda Fortaleza, para identificar as espécies de madeira que constituem a estrutura da Casa Sede, foram retiradas amostras conforme os preceitos do ICOMOS e da Carta de Veneza, quanto à autenticidade do bem. Foi retirado um total de 24 amostras, representando 24 peças de madeira. Das amostras retiradas, algumas pertencem à estrutura da casa, e outras de peças de madeira da antiga senzala que foi demolida há pouco tempo por apresentar risco de desabamento.

Em média, as amostras foram retidas em um tamanho de $1 \times 1 \times 2 \mathrm{~cm}^{3}$, ressaltando que em algumas peças, foram obtidas amostras maiores, pois a fragmentação da peça permitia colher a amostra sem agressão à peça, conforme a Figura 84.

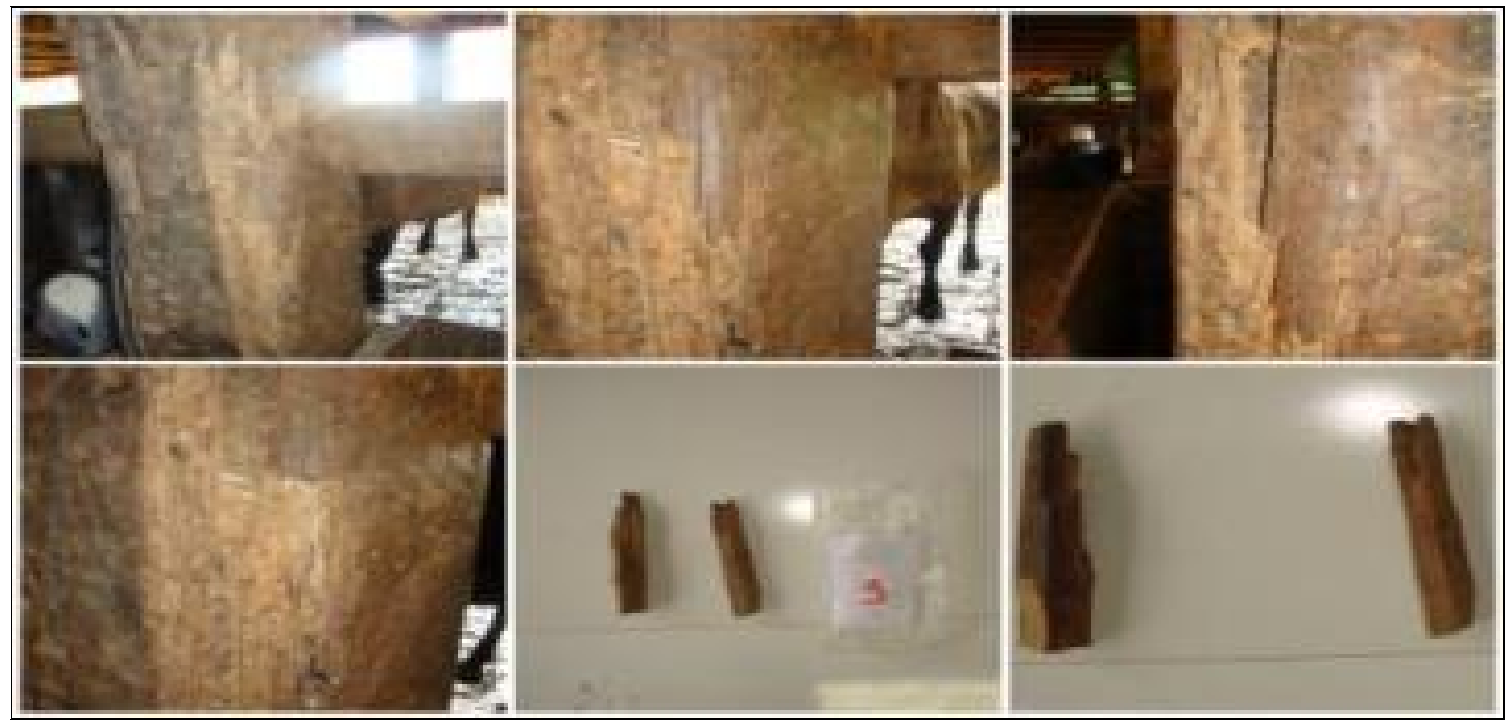

Figura 84. Peças de retirada das amostras

Depois de retiradas da estrutura da Casa Sede da fazenda Fortaleza, as amostras de madeira foram levadas para identificação de espécies pelo método macroscópico, ao Laboratório de Ciências da Madeira, no Núcleo de Estudos e de Difusão de Tecnologia em Floresta, Recursos Hídricos e Agricultura Sustentável NEDTEC, vinculado ao Departamento de Ciências Florestais e da Madeira do Centro de Ciências Agrárias da Universidade Federal do Espírito Santo DCFM/CCA-UFES, em Jerônimo Monteiro, ES, conforme Figura 84. A identificação 
macroscópica das amostras em laboratório foi utilizada com o auxílio de uma faca, uma lupa de 10 aumentos e o Manual de Chave de Identificação de Madeiras Brasileiras (MAINIERI; CHIMELO, 1989).

As amostras retiradas de diferentes peças de madeira que constituem a estrutura da casa resultaram em onze espécies diferentes. Das vinte e três amostras coletadas, quinze pertencem à estrutura da Casa Sede, seis à estrutura da antiga senzala e duas outras à ponte antiga da propriedade. As quinze amostras da casa podem ser observadas na Figura 85, que representa a localização das peças cujas amostras foram coletadas.

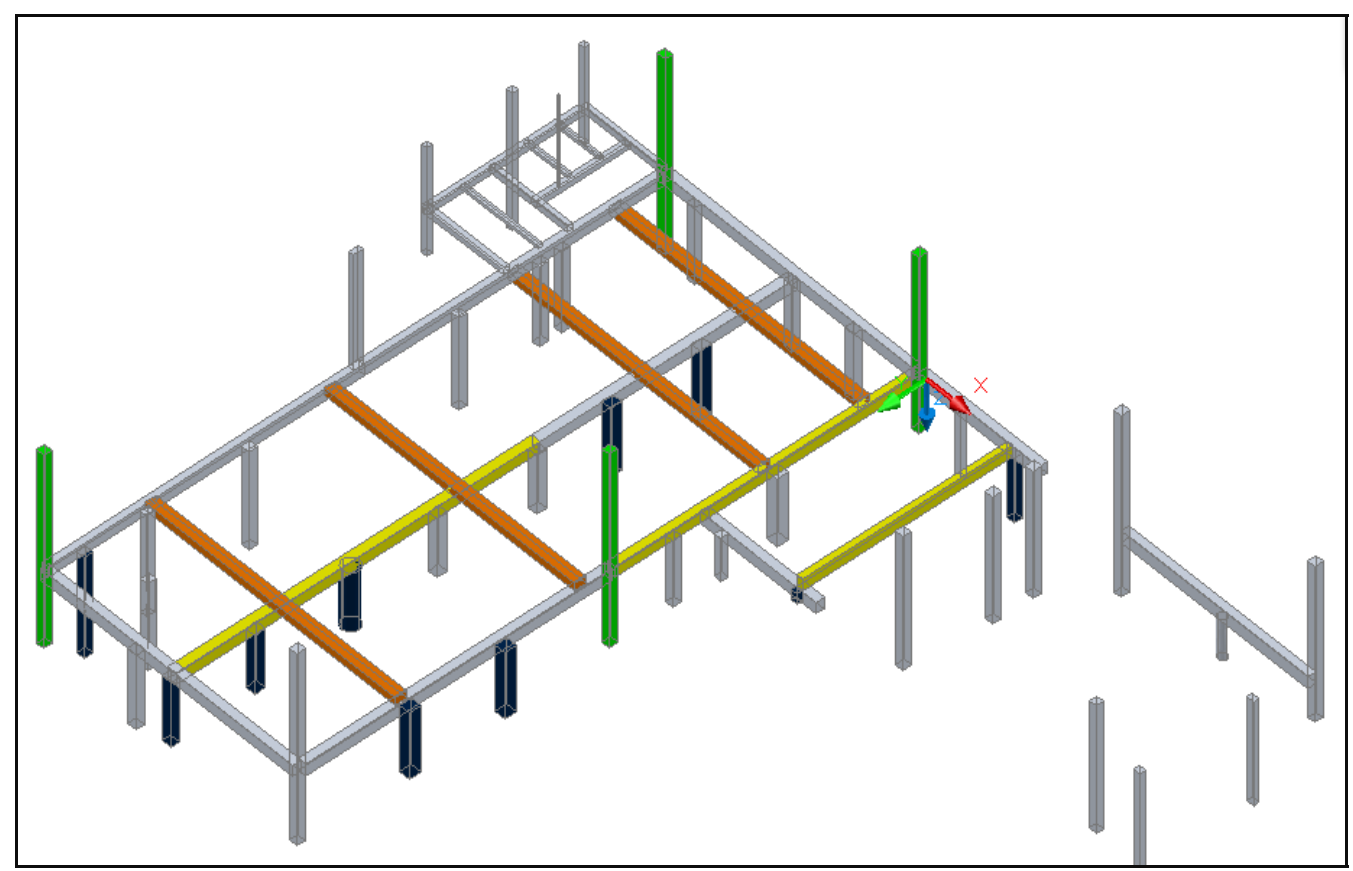

Figura 85. Representação das peças identificadas.

Os noves esteios identificados macroscopicamente apresentaram as seguintes espécies: quatro peças Braúnas (Melanoxylon brauna Schott), três Ipês Preto (Tabebuia sp), um Pau Cetim (Euxylophora paraensis), uma Sucupira (Bowdichia spp) e uma Peroba Mica (Aspidosperma spp), conforme Figura 86. 


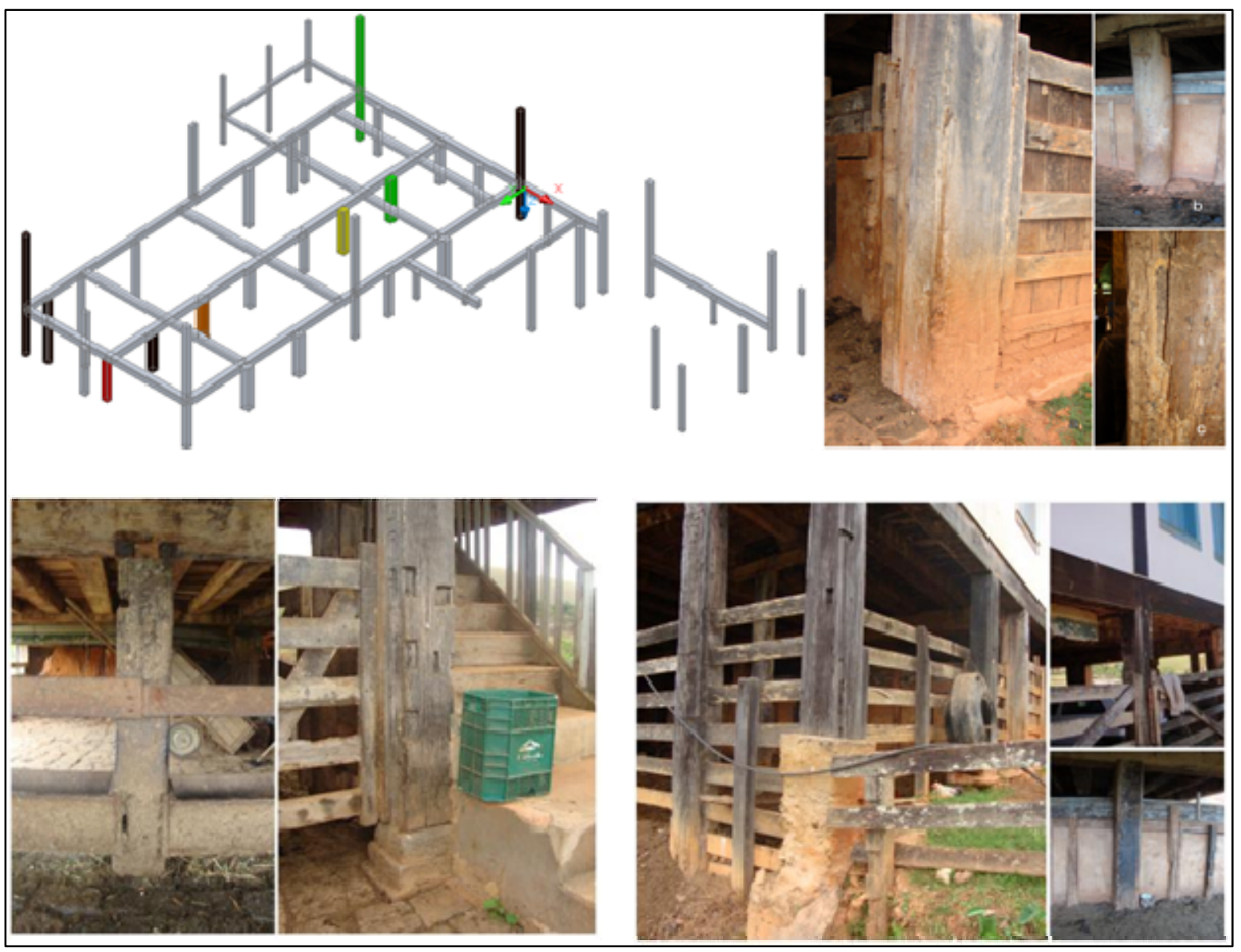

Figura 86. Representação das espécies dos esteios, em preto Braúna, em verde Ipê Preto, em amarelo Pau Cetim, em laranja Peroba Mica, e em vermelha sucupira.

O baldrame identificado macroscopicamente foi da espécie Ipê Peroba (Paratecoma peroba), Figura 87.

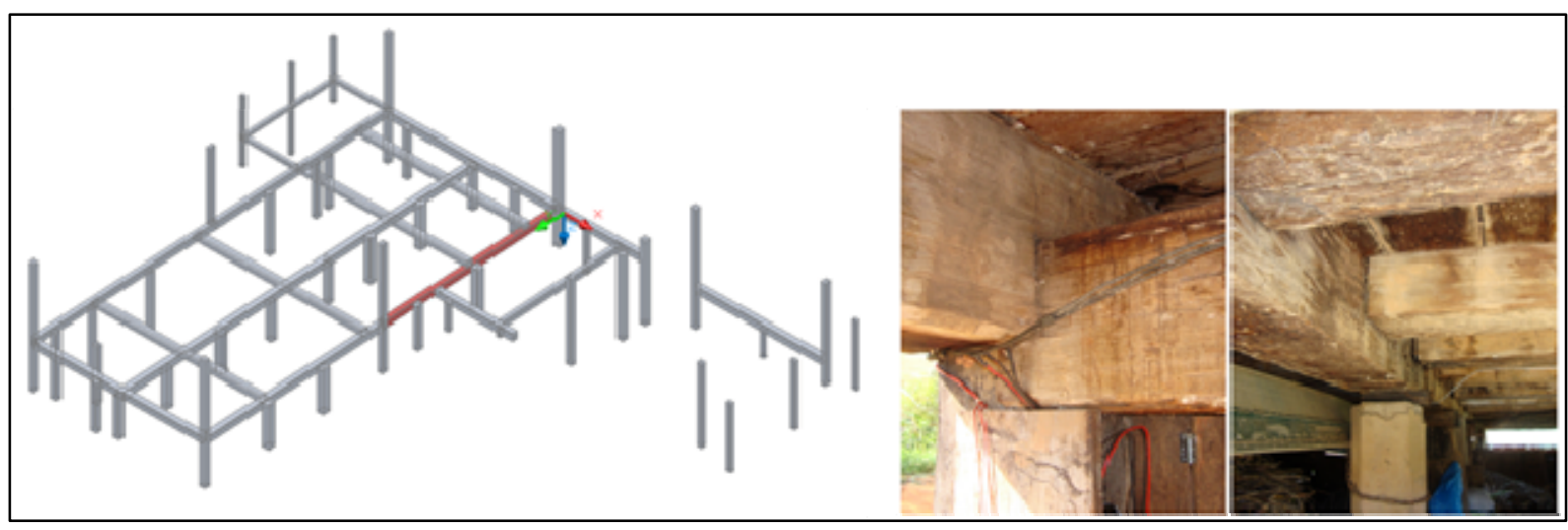

Figura 87. Representação do baldrame, Ipê peroba na cor rosa.. 
Os dois barrotes identificados macroscopicamente apresentaram as seguintes espécies: uma peça Conduru (Brosimum rubescens), um ipê preto (Tabebuia sp), e o outro Faveira Vermelha (Dimorphandra sp), Figura 88.

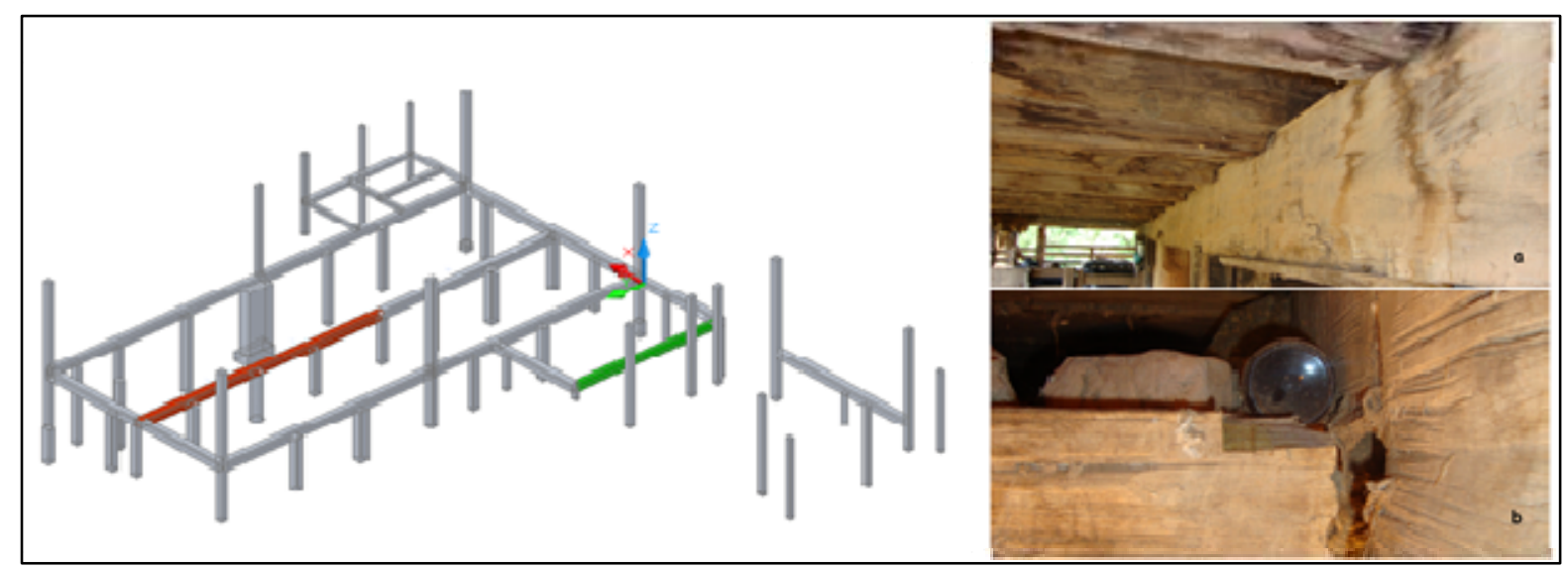

Figura 88. Representação de dois barrotes, em verde (peça mais curta) Ipê preto e em vermelho (peça mais comprida) Faveira Vermelha.

Outros quatro barrotes identificados macroscopicamente apresentaram as seguintes espécies: dois foram Conduru (Brosimum rubescens), um foi Tachi preto (Tachigalia paniculata Aubl.) e o outro foi jacarandá (Dalbergia nigra), Figura 89.

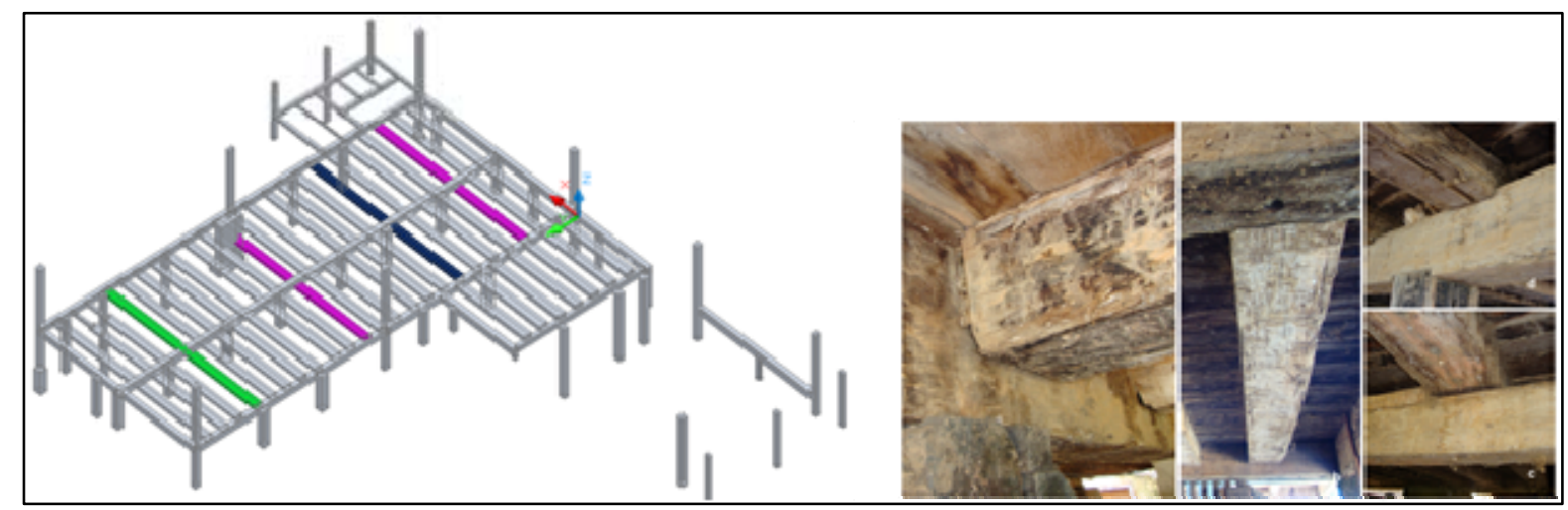

Figura 89. Representação dos barrotes secundários, em rosa conduru, em azul jacarandá, e em verde tachi preto.

As seis peças que constituíram a senzala, que foram identificadas macroscopicamente, apresentaram as seguintes espécies: duas peças em Braúnas (Melanoxylon brauna Schott), duas em Maçaranduba (Manikara spp.) e duas em Canela parda (Nectandra sp), Figura 90. 


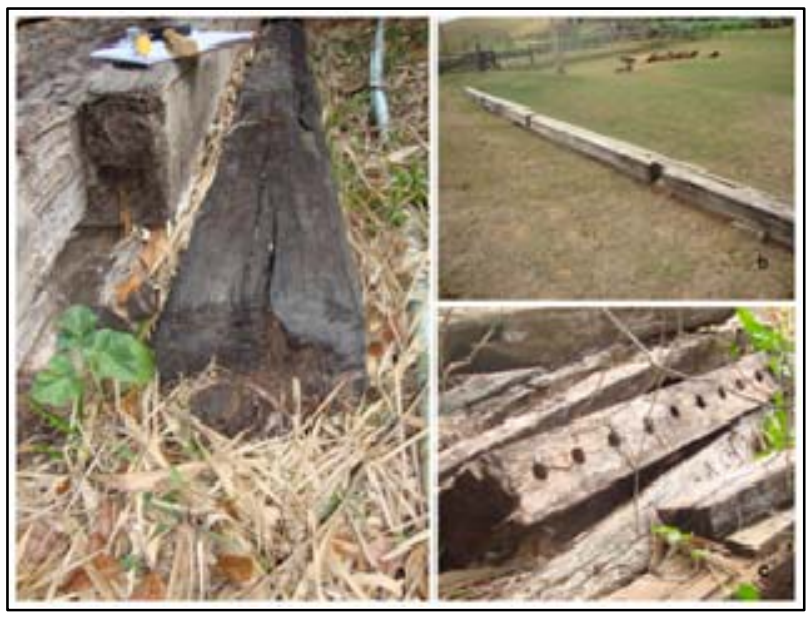

Figura 90. a: Madeira da espécie Melanoxylon brauna Schott, b: Madeira da espécie Manikara spp, c: Madeira da espécie Nectandra sp.

As duas peças que constituíram a ponte antiga foram identificadas macroscopicamente com as seguintes espécies: uma peça como Braúna (Melanoxylon brauna Schott), e a outra, Cumaru (Dipterix odorata), Figura 91.

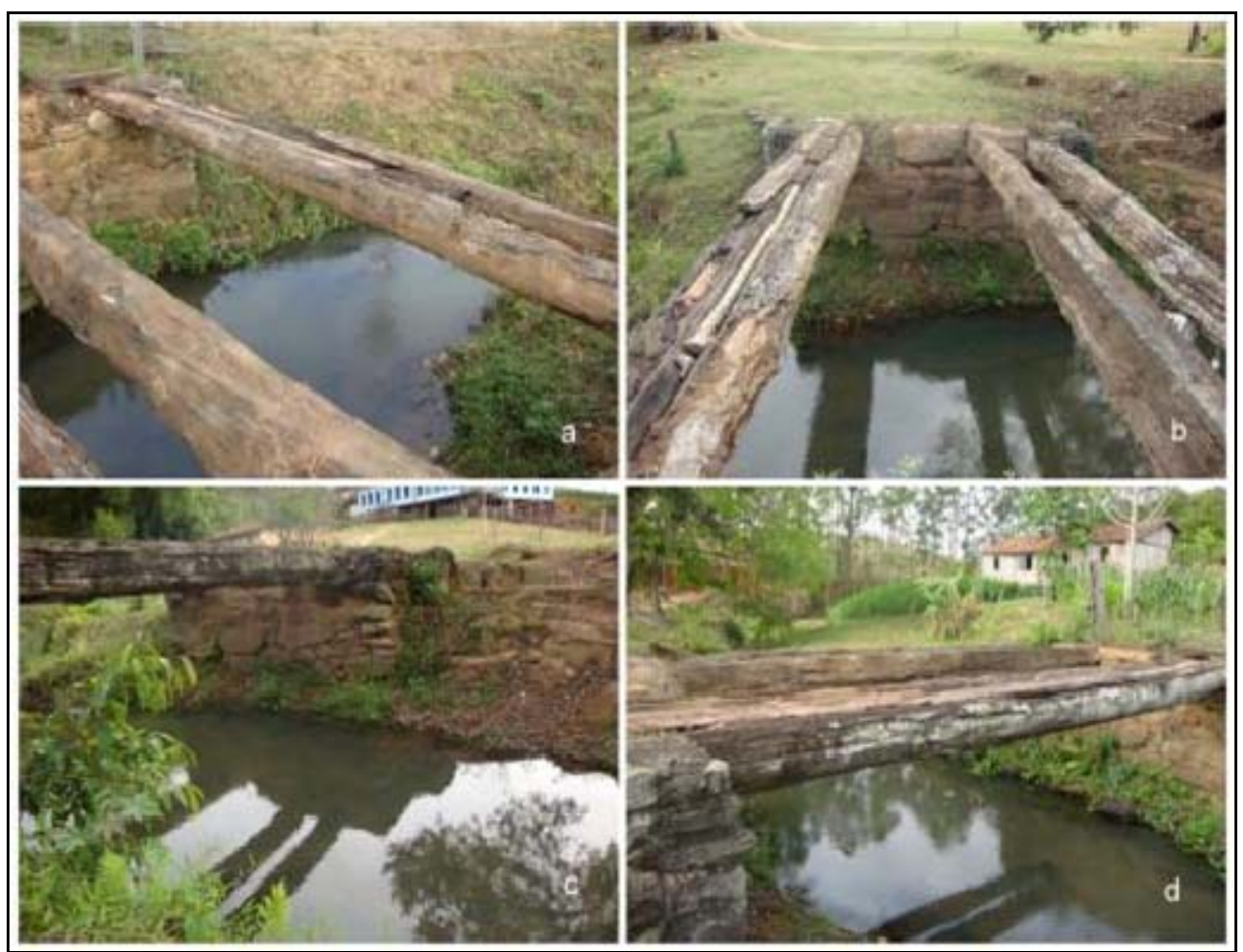

Figura 91. a e b: Ilustração da ponte, c: Madeira da espécie Dipterix odorata, d: Madeira da espécie Melanoxylon brauna Schott. 


\section{A madeira e a estrutura da Casa Sede}

Ao analisar as relações estruturais dos elementos em madeira presentes na fazenda Fortaleza, Casa Sede, fragmento da antiga senzala e ponte, destaca-se que as peças estruturais utilizadas horizontalmente, estão submetidas principalmente à flexão, cuja força provoca encurvamento na madeira, como os barrotes, o baldrame e as peças mapeadas na antiga ponte. Cada espécie de madeira identificada em catálogo apresenta resistência diferente à flexão, conforme registrado na Tabela 16, que ainda pode variar de madeira para madeira em uma mesma espécie (CHIMELO e MANIERI, 1989).

Tabela 16. Resistência média à flexão estática $\left(\mathrm{kgf} / \mathrm{cm}^{2}\right)$ das madeiras identificadas na Casa Sede.

\begin{tabular}{lccc}
\hline Nome Vulgar & $\begin{array}{c}\text { Resistência } \\
\left(\mathbf{k g f /} / \mathbf{c m}^{2}\right)\end{array}$ & Classificação & Uso \\
\hline Braúna preta & 1,916 & Alta & Barrote primário/Ponte \\
Ipê Preto & 1,514 & Alta & Barrote primário \\
Ipê Peroba & 1,186 & Médio & Baldrame \\
Faveira vermelha & 0,813 & Baixa & Barrote Primário \\
Cumaru & 1,818 & Alta & Ponte - Horizontal \\
Conduru & 1,394 & Alta & Barrote Secundário \\
Jacarandá & 1,383 & Alta & Barrote Secundário \\
\hline
\end{tabular}

Fonte: Adaptado de Mainieri at Chimelo (1989).

É possível verificar que todas as peças estruturais analisadas na fazenda Fortaleza e que estão submetidas à flexão são espécies de alta resistência, com exceção do Ipê Peroba, que possui media resistência, e da Faveira Vermelha, com baixa resistência. Os barrotes de Braúna e Ipê Preto possuem alta resistência à flexão. Eles apresentam dimensões avantajadas e também recebem apoio de 
esteios a meia altura. Esses apoios diminuem o vão e consequentemente, o momento fletor solicitante. Os demais barrotes identificados possuem alta resistência à flexão, além disso, as peças são apoiadas por outro barrote, o que possibilita a diminuição da força de curvamento da peça na posição horizontal.

Os troncos que constituem a antiga ponte são peças robustas, das espécies Braúna e Cumaru, e são de alta resistência a flexão. Os esteios, importantes peças estruturais, estão submetidos à força de compressão. De acordo com o Chimelo at Manieri, (1989) cada espécie de madeira identificada apresenta uma resistência à compressão diferente, registrada na Tabela 17, que também pode variar de acordo com a espécie de madeira.

Tabela 17. Resistência à compressão, paralela às fibras $\left(\mathrm{kgf} / \mathrm{cm}^{2}\right)$ das madeiras identificadas na Casa Sede.

\begin{tabular}{cccc}
\hline Nome Vulgar & Resistência $\left(\mathbf{k g f} / \mathbf{c m}^{2}\right)$ & Classificação & Uso \\
\hline Braúna preta & 946 & Alta & Esteio \\
Ipê Preto & 748 & Alta & Esteio \\
Pau cetim & 708 & Alta & Esteio \\
Sucupira & 952 & Alta & Esteio \\
Peroba Mica & 683 & Alta & Esteio \\
\hline
\end{tabular}

Fonte: Adaptado de Mainieri at Chimelo (1989).

A resistência à deterioração da madeira varia de acordo com a espécie e até mesmo na própria madeira, em que o alburno está bem mais suscetível a deterioração que o cerne.

Pode-se observar que na Tabela 18, a madeira como a Canela Parda, que foi utilizada para a construção da senzala, possui baixa resistência ao ataque de fungos e insetos xilófagos. A madeira como o Ipê Peroba, utilizada como baldrame, apresenta satisfatória durabilidade natural. Já as madeiras como Braúna, Ipê Preto, Pau Cetim, Sucupira e Peroba Mica são peças que estão em contato com o solo ou em maior exposição a intempéries, e apresentam alta resistência ao ataque de fungos e insetos xilófagos. 
A durabilidade natural de cada espécie de madeira influencia diretamente no tempo de exposição das peças levantadas na Casa Sede. É importante lembrar que mesmo com alta resistência a fungos e resistente ao ataque de xilófagos, as espécies como o Cumaru e Braúna, nas peças da ponte, estão com a superfície significativamente deteriorada, tendo em vista a longa exposição dessas peças ao intemperismo e a fatores biológicos de degradação da madeira.

Tabela 18. Durabilidade natural das espécies de madeira identificadas na Casa Sede.

\begin{tabular}{cccc}
\hline Nome Vulgar & Nome Científico & \multicolumn{2}{c}{ Durabilidade Natural } \\
\cline { 2 - 4 } & & Fungos & Cupins \\
\hline Braúna preta & Melanoxylon brauna Schott & - & Muito Alta \\
Ipê Preto & Tabebuia sp & Muito Alta & Alta \\
Pau cetim & Euxylophora paraensis & Muito alta & - \\
Sucupira & Bowdichia spp & Alta & Alta \\
Peroba Mica & Aspidosperma spp & - & Alta \\
Faveira vermelha & Dimorphandra sp & - & Resistente \\
Ipê Peroba & Paratecoma peroba & Satisfatória & - \\
Maçaranduba & Manikara spp. & Moderada/ & - \\
Cumaru & Dipterix odorata & Alta & \\
Canela parda & Nectandra sp & Alta & Resistente \\
Conduru & Brosimum rubescens & - & Baixa \\
Jacarandá & Dalbergia nigra & Alta & Alta \\
\hline
\end{tabular}

Fonte: Adaptado de Mainieri at Chimelo (1989).

O sistema estrutural em madeira das construções antigas como a Casa Sede da Fazenda Fortaleza, é concebido para suportar toda a carga da edificação. De acordo com o levantamento realizado, a estrutura de madeira da casa é autônoma, do tipo gaiola, tradicional em Minas Gerais e no sul do Espírito Santo.

O mapeamento dos elementos construtivos permitiu identificar e detalhar o sistema estrutural da Casa Sede, na qual, por meio das análises, foi possível perceber que além das espécies de madeira, seu dimensionamento é responsável por suportar as cargas provenientes de todo o telhado, alvenaria e pisos. É importante destacar ainda que as formas de encaixes das peças de madeira 
registram e descrevem a técnica construtiva, e sua condição física atual ilustra parte do comportamento estrutural do edifício ao longo do tempo.

Por ser uma construção que se estabeleceu em uma época de desbravamento da região, foi possível comprovar que algumas das espécies de madeiras utilizadas na construção eram madeiras oriundas da mata atlântica, na qual espécies como a Braúna e a Peroba já haviam sido citadas em documentos antigos que pertencem às terras da Fazenda Fortaleza. É importante destacar ainda, que todas as espécies que foram identificadas apresentam boas características físico-mecânicas e boa relação quanto à durabilidade natural, que é um fator preponderante para o edifício manter-se conservado por mais de 150 anos, demonstrando o conhecimento dos antigos mestres construtores quanto à espécie de madeira e seu adequado uso na estrutura de um edifício, conforme manuais de agricultura.

Após identificação de espécies de madeira utilizadas na fazenda Fortaleza, e realização do confronto com as espécies indicadas pelo Barão de Paty para construção de uma fazenda, verifica-se que, para os esteios, apenas a espécie "pau cetim" aparece dentre aquelas identificadas na fazenda Fortaleza; todas as demais são sugeridas, conforme Werneck (1878, p.15 a 17). Convém destacar ainda que todas aquelas indicadas pelo autor apresentam alta durabilidade natural, conforme Mainieri at Chimelo (1989), e a própria existência e integridade das peças na fazenda Fortaleza, assim como a alta resistência à compressão, confirmam essa condição. 


\section{CONCLUSÃO}

No processo de sistematização do conhecimento relativo ao patrimônio rural na região sul do estado do Espírito Santo, para atender demandas de reconhecimento e adequada gestão do acervo a que ele compõe, evidencia-se a necessidade de precisão destes dados a serem fornecidos e analisados. É necessária e correta administração dos mesmos, desde o reconhecimento do objeto em si, que parte da identificação da área, passando pela definição das variáveis e do método de avaliação e distribuição espacial, até o processamento final dos dados e a geração de resultados espaciais e sociais.

Em termos de técnicas de mapeamento e cadastramento de acervos arquitetônicos notam-se mudanças significativas a partir do surgimento principalmente de novos instrumentos, tais como GPS, imagens de satélites de alta resolução, fotografias digitais e sistemas fotogramétricos com processamentos totalmente digitais, além de uma sensível redução de custos de equipamentos e serviços, tornando os instrumentais geotécnicos mais acessíveis à comunidade científica.

Geotecnologias contemplam a temática das imagens ópticas, imagens de radar, Sistemas de Informação Geográfica, bases de dados e análise espacial; e ainda, sistemas de posicionamento global que tratam da cartografia e levantamentos de campo. O geoprocessamento inclui técnicas para o tratamento de informações que possuem como atributo intrínseco a sua posição no espaço. Por meio dos SIGs, é possível realizar análises complexas, integrar dados de diversas fontes e criar bancos de dados georeferenciados, possibilitando automatizar a produção de documentos cartográficos. Essa condição traz à gestão do patrimônio rural importante possibilidade de avanço e manutenção do acervo. Os parâmetros morfométricos e de uso da terra se mostraram eficientes às análises do ambiente rural percebido como bem cultural, revelando os Fatores de Fragilidade Morfológica e Cultural - FFMC, para o ambiente rural. 
De posse de informações precisas e exatas contidas nos cadastros geotecnificados do patrimônio rural, os gestores de bens culturais, assim como a população interessada na preservação e manutenção deste acervo, poderão com maior facilidade detectar as necessidades de manutenção dos bens culturais, priorizando os fatos segundo as visões emergenciais, preventivas e reativas, de manutenção e de melhorias. Para isso, é preciso observar as variáveis que se têm disponíveis, pois a partir dessas informações é que se pode escolher o recurso metodológico a ser aplicado e, por isso, conclui-se que o método comparativo de dados - AHP, atrelado à leitura fenomenológica, é pertinente e eficiente às análises e gestão do patrimônio rural, pois leva em consideração a realidade do acervo em sua diversidade, gerando o Índice de Sensibilidade Cultural para o Ambiente Rural SCAR.

Por isso, acredita-se que com auxílio de estudos geotecnificados, com destaque para as possíveis análises que o Índice de Sensibilidade Cultural possibilita, possam se tornar mais eficazes os procedimentos de preservação e conservação de bens culturais, uma vez que consideram a identificação e o diagnóstico do patrimônio cultural e sua infraestrutura básica e indicam áreas e regiões adequadas a receber ações diretas de conservação sobre a matéria, em região específica do objeto em questão. O mapeamento da Sensibilidade Cultural possibilita ainda a promoção da integridade das áreas do universo rural determinado por partes isoladas, relacionadas entre si, incluindo prioritariamente as relações que caracterizam o meio ambiente rural como único.

Foi adotada a Fazenda Fortaleza, em Alegre, ES, como modelo experimental para verificação dos procedimentos científicos apresentados. Uma vez verificada a eficiência da aplicabilidade das ferramentas geotecnificadas, sugere-se que devam ser igualmente contemplados, os estudos de análise morfométrica, uso da terra e Sensibilidade Cultural para o Ambiente Rural para as demais fazendas identificadas entre os vales dos rios Itabapoana e Itapemirim. Além de se considerar oportuno eleger para aprofundamento todos os Fatores de Fragilidade Morfológica e Cultural, e não apenas o de maior peso estatístico, como foi feito para a Casa Sede, que possibilitou verificar as espécies de madeira que foram identificadas com boas características físico-mecânicas e durabilidade natural adequada ao uso atribuído pelo sistema estrutural da Casa Sede. 
Considera-se ainda oportuno realizar pesquisa do patrimônio rural representativo por unidade edificada, e delas relacionadas entre si, ocasionando leitura global da região a partir dos parâmetros temáticos, históricos, estéticos e morfológicos, sendo possível ampliar as análises de Sensibilidade Cultural por macro regiões temáticas.

As ferramentas de geotecnologia permitem leituras em vastas regiões ambientais, podendo o patrimônio rural cultural ser adequadamente contemplado, ocasionando a oportunidade de gerar a Sensibilidade Cultural para o Ambiente Rural das fazendas antigas do estado do Espírito Santo e da região cafeeira do sul, do centro sul e do norte do estado, disponibilizando instrumento de gestão globalizada do patrimônio rural. 


\section{REFERÊNCIAS}

ABREU, João Capistrano. Caminhos Antigos e Povoamento do Brasil. 2 ed. $1^{\text {a }}$ edição: 1930. Rio de Janeiro: Sociedade Capistrano de Abreu/ Livraria Briguiet, 1960.

ALMADA, Vilma Paríso Ferreira de. Estudos sobre Estrutura Agrária e Cafeicultura no Espírito Santo. Vitória: SPDC/UFES, 1993.

, Vilma Paríso Ferreira de. Escravismo e transição: o Espírito Santo,1850 1888. Rio de Janeiro: Edições Graal, 1984.

AGENCIA NACIONAL DE ÁGUAS - ANA. Sinopse das Bacias Hidrográficas do Atlântico Sul: trecho leste. Volume I. Governo Federal. Brasília 2001. 42p.

BARBOSA, Ana Aparecida. Uma fresta na neblina: estudo da possibilidade de restauro urbano do Serro. 2007. Dissertação (Mestrado em Teoria e História da Arquitetura e do Urbanismo) - Escola de Engenharia de São Carlos, Universidade de São Paulo, São Carlos, $2007 . \quad$ Disponível em: <http://www.teses.usp.br/teses/disponiveis/18/18142/tde-28072007-090657/>.

BOTELHO, Demerval Alves. História de Manhumirim: município e paróquia. Volume I - 1808 a 1924. Belo Horizonte, Editora O Lutador. 196p.

BOLTSHAUSER, João. História da Arquitetura. Belo Horizonte: Escola de Arquitetura da UFMG, 1972. (Volume VI, Parte I).

BRANDI, Cesare. Teoria da restauração. Cotia: Ateliê, 2005.

BRAVO, Carlos Magno Rodrigues. Nossas raízes. O Alegre até o ano de 1920: Fatos e Biografias. Alegre-ES, 1998. p. 216.

CASSAR, May. Environmental Management: Guidelines for Museums and Galleries. London and New York: Routledge., 1997.

CANEPARO, S. C. Análise da Dinâmica Espacial e dos Impactos Ambientais causados pela Ocupação Antropica em áreas de manguezais de Paranaguá-Paraná, 
Através de Técnicas de Geoprocessamento . In: X SBSR. 2001, Foz do Iguaçu. Poster. Foz do Iguaçu: 2001, p 561-566.

CARDOSO, Joaquim. Um tipo de cada rural do Distrito Federal. In: Arquitetura Civil II. Textos escolhidos da Revista do Instituto do Patrimônio e Artístico nacional. São Paulo: FAUUSP - MECIPHAN. 1975. 260p.

CARTA de Veneza, ICOMOS, 1964. Disponível em: www.iphan.gov.br/cartas.htm. Acesso em 12 de fevereiro de 2004.

CARSALADE, Flavio de Lemos. Desenho contextual: uma abordagem fenomenológico-existencial ao problema da intervenção e restauro em lugares especiais feitos pelo homem. 475 f. Tese (Doutorado em Arquitetura e Urbanismo) Universidade Federal da Bahia, Salvador, 2007.

CARRILHO, M. J. (2006). Fazendas de café oitocentista no vale do Paraíba. Anais do Museu Paulista. São Paulo. N. Sér. V.14 n.1.p.p.59-80. Jan-jun.

CARVALHO, Elizabeth Sales de. Arquitetura rural na microrregião metropolitana de Belo Horizonte: investigação sobre tipologias arquitetônicas nos séculos XVIII e XIX. Dissertação de Mestrado em Arquitetura pela Universidade Federal de Minas Gerais. 2003.

CHACALTANA, Teresa Susana Aquije. Mapeamento de áreas de sensibilidade ambiental ao derrame de óleo na Baía de Vitória, ES. Dissertação de Mestrado em Engenharia Ambiental. Universidade Federal do Espírito Santo (UFES). 2007. 140p.

CHIMELO J. P. . Anatomia e Propriedades Gerais da Madeira. In: OLIVEIRA, J. T. da S.; FIEDLER, N. C.; NOGUEIRA, M. Tecnologias Aplicadas ao Setor Madeireiro. Jerônimo Monteiro: Suprema, 2007. p 107-124.

COBRA, Rubem Queiroz. Filosofia Contemporânea. Disponível em: <WWW.cobra.pages.nom.br>. Acesso em: 20 nov. 2005.

COSTA, Arlindo. Coletânea de Anatomia da Madeira. 2001. Disponível em: $<$ http://www.joinville.udesc.br/sbs/professores/arlindo/materiais/APOSTILANATOMIA 1.pdf>. Acesso em: 16 abr. 2010.

COSTA, Antônio Gilberto; RENGER, Friedrich Ewald,; FURTADO, Júnia Ferreira; SANTOS, Márcia Maria Duarte dos. Cartografia da conquista do território da Minas. Belo Horizonte: Editora da UFMG, 2004. 245 p. 
CORREA, Francisco Ferreira. Relatório lido no paço da Assembleia Legislativa da Província do Espírito Santo na sessão ordinária do ano de 1871. Vitória. Tipografia do Correio da Victoria 1871. 148p.

COZEN, Michael RG (2009). As paisagens urbanas históricas na Inglaterra: um problema de geografia aplicada p.46. In CASTRIOTA Leonardo Barci. Paisagem cultural e Sustentabilidade. Belo Horizonte: IEDS: UFMG, 2009. 233p. ISBN

DARÉ, Raquel. A crise do café e a ideologia desenvolvimentista no Espírito Santo. Dissertação de Mestrado em Geografia pela Universidade Federal do Espírito Santo. 2010.

Departamento do Patrimônio Cultural e Natural / INEPAC. Projeto Inventário de Bens Culturais Imóveis: Desenvolvimento Territorial dos Caminhos Singulares do Estado do Rio de Janeiro. 2004.

FELGUEIRAS, C. A. E,; GOODCHILD, M. F. Two Papers on Triangulated Surface Modeling. Santa Bárbara: University of California, 1995.

FILHO, Britaldo Silveira Soares. Análise de Paisagem: fragmentação e mudanças. Departamento de Cartografia, Centro de Sensoriamento Remoto. Instituto de Geociências. UFMG. Apostila. 1998.

GADAMER, Hans-Georg. Verdade e Método I. Petrópolis: Vozes, 2004. 631 p.

GALEFFI, Dante Augusto. Hermenêutica do restauro (Uma leitura heideggeriana como restauração da questão esquecida: o restauro como "cura"). 1994. 242 f. Dissertação (Mestrado em Arquitetura e Urbanismo) - Universidade Federal da Bahia, Salvador, 1997.

GARCIA, Valéria Eugênia. As tramas e o poder: Jaboticabal 1895 - 1936 praça, igreja e uma outra história. Dissertação de mestrado em Arquitetura e Urbanismo pela Universidade de São Paulo. Escola de Engenharia de São Carlos. 2008. 308p.

GOMES, L. F. A. M.; ARAYA, M. C. G.; CARIGNANO, C. Tomada de Decisões em Cenários Complexos. São Paulo: Pioneira, 2004

GRANZINOLLI, Marco Antônio Monteiro. Levantamento, área de vida, uso e seleção de hábitat de Falconiformes na região central do Estado de São Paulo, 2009. Tese (Doutorado em Ciências na área de Ecologia). Instituto de Biociências da Universidade de São Paulo. 2009. 
GROHMANN, Carlos Henrique. Técnicas de Geoprocesamento aplicadas à análise morfométrica. Dissertação de Mestrado. Pós-gradução em Geoquímica e Geotectônica pela Universidade de São Paulo. Instituto de Geociências. 2004. 78p

GUIMARÃES, Alberto Passos. Formação da pequena propriedade: intrusos e posseiros. In: Quatro séculos de latifúndio. 6ª Ed. Rio de Janeiro: Paz e Terra. 1989. p.105-119.

GONÇALVES, Andréa Lisly. Estratificação Social e Mobilizações Políticas no Processo de Formação do Estado Nacional Brasileiro: Minas Gerais, 1831-1835. São Paulo : Aderaldo \& Rothschild; Belo Horizonte, MG : Fapemig, 2008. 152p.

HOLLAND, D. A.; BOYD, D. S.; MARSHALL, P. Updating topographic mapping in Great Britain using imagery from high-resolution satellite sensors. Journal of Photogrammetry \& Remote Sensing, 60, p. 212-223, 2006.

HALFELD, H. G. F.; WAGNER, F. A provincial brasileira de Minas Gerais. 1998. $176 p$.

HOUAISS, Antônio. Novo Dicionário Houaiss da Língua Portuguesa. Rio de Janeiro: Objetiva, 2009. 1986p.

HEIDEGGER, Martin. Ser e Tempo. Volume I. Petrópolis: Vozes, 2004. 262 p.

A Origem da Obra de Arte in Poetry, Language, Thought. New York: Harper \& Row Publishers, 1975. p. 17-87.

INSTITUTO BRASILEIRO DE GEOGRAFIA E ESTATÍSTICA (2006). Manual técnico de uso da terra. Rio de Janeiro: Disponível em: <http://www.ibge.gov.br>. Acesso em: 12 ago. 2010.

INSTITUTO DE DEFESA AGROPECUÁRIA E FLORESTAL DO ESPÍRITO SANTO (1924). Processo de legitimação de terras referente a Fazenda da Fortaleza, município de Alegre: pedido de Euzebio Cabral sendo possuidor desde 1842. Seção Fundiária. Divisão de Terras e Colonização, Placidina n.226, Livro 14, folha 91. Divisão Fundiária_IDAF. 146 folhas.

KILL, Miguel A. Terra capixaba: geografia \& história. Vitória: edição do autor. 2005. $92 p$. 
KÜHL, Beatriz Mugayar. História e ética na conservação e na restauração de monumentos histórico. Revista CPC. São Paulo, v.1, p.16-40, Nov. 2006. Disponível em < www.usp.br.cpc>. Acesso em set. 2006.

, Beatriz Mugayar. Arquitetura do ferro e arquitetura ferroviária em São Paulo, reflexões sobre a sua preservação. São Paulo, Ateliê, SEC, FAPESP, 1998.

Beatriz Mugayar, Patrimônio Industrial: algumas questões em aberto. UFJT - ARQ.URB. Número 3/ primeiro semestre de 2010. São Paulo, 2010.

LABORIE, P. J. O fazendeiro de café na ilha de São Domingos. In: O fazendeiro do Brasil.Rio deJaneiro: Officinas de S.T. Ferreira, 1799.

LEMOS, Carlos A. C. História da casa brasileira.São Paulo: Editora Contexto, 1989. $83 p$.

, Carlos A. C. Casa Paulista: história das moradias anteriores ao ecletismo trazido pelo café.São Paulo: Edusp, 1999.

LEMOS II, D. L.; CORDINI, J.; LOCH, C.Potencialidades da Fotogrametria Digital para Avaliação de Unidades de Conservação. In XXI Congresso brasileiro de cartografia, 2004. Disponível em: <httpllwww.cartografia.org.br/xxi.cle.htm\#tec4 > Acesso em: 20 abr. 2010

LINHARES, Maria Yeda; SILVA, Francisco Carlos Teixeira. A questão da agricultura de subsistência. História da Agricultura Brasileira. São Paulo: Brasiliense. 1981. p. 117-136.

MAINIERI, C.; CHIMELO, J.P. Fichas de características das madeiras brasileiras. São Paulo: IPT, 1989. 418p.

MAZZINI, P. L. F.; SCHETTINI, C. A. F. Avaliação de metodologias de interpolação espacial aplicadas a dados hidrográficos costeiros quasesinóticos. Braz. J. Aquat. Sci. Technol., v. 13, n. 1, p. 53-64, 2009.

MERLEAU-PONTY, Maurice. Fenomenologia da percepção. São Paulo: Martins Fontes, 1999. 662 p.

MOURA, Ana Clara Moura. Geoprocessamento aplicado ao planejamento urbano e à gestão do patrimônio histórico de Ouro Preto - MG. Disponível em: < http://www.cartografia.org.br/xxi_cbc/177-SG42.pdf> Acesso em outubro de 2011. 
MOURA, Ana Clara Moura. Elaboração e análise do perfil de fragilidade social do município de Sabará - MG como apoio ao planejamento e gestão urbana em escala municipal. XXIV Congresso Brasileiro de Cartografia - Aracaju _SE, Brasil, 16 a 20 de maio de 2010.

MOURA, Marcela M., COSTA, Gilberto A., MOURA, Ana Clara M. TOLENTINO, Mônica M. O uso de sistema de informação geográfica para controle de patologias em rochas de monumentos: estudo de caso de edificação histórica na cidade de Serro, Minas Gerais, Brasil._XIII CONFIBSIG - Conferencia Iberoamericana de Sistemas de Información Geográfica. Toluca, México. 25 a 28 de maio, 2011. 15 p.http://www.inegi.org.mx/eventos/2011/conf_ibero/

MOREIRA, Vânia Maria Losada. Nem selvagens nem cidadãos: os índios da vila de Nova Almeida e a usurpação de suas terras durante o século XIX. Revista de História (UFES), Vitória, ES, v. 14, n. 14, p. 151-168, 2002.

MUNIZ, Maria Isabel Perini. Cultura e arquitetura: a casa rural do imigrante italiano no Espírito Santo. Vitória: EDUFES. 1997. 217p

, Maria Isabel Perini. Arquitetura rural do século XIX, no Espírito Santo. Vitória, Aracruz Celulose - Fundação Jônice Tristão - rede gazeta - Xerox do Brasil, 1989 EDUFES. 1989. 217p.

NETO, Jaime Bernardo. Pequenas Propriedades Rurais e Estrutura Fundiária no Espírito Santo: uma tentativa de entendimentos das particularidades capixabas. Monografia de Graduação em Geografia. Departamento em Ciências Humanas. Universidade Federal do Espírito Santo. 2009.177p.

OLIVEIRA, José Teixeira. História do Espírito Santo. Vitória: Fundação Cultural do Espírito Santo. 1975. $2^{\mathrm{a}}$ Ed.

OLIVEIRA, Zélia Cassa de Oliveira (Org.). Abertura do Caminho de Arripiados à Última Cachoeira do Rio Itapemirim. Alegre: Casa de Cultura, 2009. (Cadernos de Estudos, Vol.1, no1).

ORGANIZAÇÃO DAS NAÇÕES UNIDAS PARA A AGRICULTURA E ALIMENTAÇÃO - FAO - Termos e definições, utilizados na Avaliação Global dos Recursos Florestais (FRA).In: sistema Nacional de Informação Florestal. Disponível em:<http://www.florestal.gov.br/snif/recursos-florestais/definicao-de-floresta>. Acesso em Jan.1012. 
Ordem do Real Erário, de 18 de novembro de 1773. Arquivo Nacional, Fundo Família Lobo Leite Pereira; In. Demerval José Pimenta. Caminhos de Minas Gerais. Belo Horizonte: Imprensa oficial, 1971. p.22-23.

PETRONE, Maria Thereza Schorer. O imigrante e a pequena propriedade no país dos latifúndios. In: O imigrante e a pequena propriedade (1824-1930). 2a Ed. São Paulo: Brasiliense. 1984. p. 7-37.

PINHO, C. M. D.; KUX, H.; ALMEIDA, C. M. Influência de diferentes padrões de ocupação do terra urbano na qualidade de mapeamentos de cobertura do terra em imagens de alta resolução espacial: estudo de caso de São José dos Campos (SP). In: BLASCHKE, T.; KUX, H. (Org). Sensoriamento Remoto e SIG Avançados. São Paulo: Oficina de textos, 2007.

POSENATO, Julio. Arquitetura da imigração italiana no Espírito Santo. Porto Alegre Arte \& Cultura. 1997. 560p.

RANGEL, M. E. S.; KUX, H. J.H.; SANTOS, J. R.; FEITOSA, A. C. Sensoriamento remoto e GIS na analise de modificações da paisagem em manguezais. In: X SBSR. 2001, Foz do Iguaçu. Poster. Foz do Iguaçu: 2001, p 1721-1733.

ROSOT, M. A. D.; BARCZAK, C. L.; COSTA, D. M. B. Análise da vulnerabilidade do manguezal do Itacobi a ações antrópicas utilizando imagens de satélite e técnicas de geoprocessamento. COBRAC 2000, UFSC. Florianópolis. Congresso brasileiro e cadastro técnico multifinalitário. 15 a 19 de outubro de 2000. Disponível em: <http://geodesia.ufsc.br/geodesia-online/arquivo/cob2000.htm> Acesso em: 10 abr. 2010.

RUBIM, Francisco Alberto. Descrição da Estrada para a Província de Minas Gerais pelo rio Santa Maria. In. Revista do instituto Histórico e Geográfico Brasileiro. Tomo 6, I, nº.6, pp. 469-470, 1844.

SAATY. T. H. A Scaling Method For Priorities in Hierarchical Structures. Journal of Mathematical Psychology, v. 15, n 3, p. 234-281, 1977.

SAINT-HILAIRE, Auguste de. Viagem ao Espírito Santo e Rio Doce. São Paulo: Editora da Universidade de São Paulo; Belo Horizonte: Itatiaia, 1974. p.109.

SANTOS, Alexandre Rosa dos. Caracterização Morfológica, Hidrológica e Ambiental de uma Bacia Hidrográfica usando o spatial anlyst e o 3D anlyst do ArcGis 10. Vitória, UFES. Disponível em <Http://www.mundogeomatica.com.br/SIG_PPGCF.htm> Acesso em: 10 mar. 2010. 
SANTOS, Aexandre Rosa.; LOUZADA, F. L. R. O.; EUGENIO, F. C. ARCGIS 10 total: aplicações para dados espaciais. Alegre, ES : CAUFES, 2010. 184 p.

TOGNON, Marcos; BORTOLUCCI, Maria Angela P.de C. e S.; OLIVEIRA, A. C. de; MARCONDES, M. Patrimônio Cultural rural paulista: espaço privilegiado para pesquisa, educação e turismo. $2^{\circ}$ Seminário de Patrimônio Agroindustrial: lugares de memória. 19 a 22 de outubro de 2010. São Carlos, SP.

VALERIANO, M. de M. Curvatura vertical de vertentes em microbacias pela análise de modelos digitais de elevação. Revista Brasileira de Engenharia Agrícola e Ambiental, v. 7, n. 3, p. 539- 546, 2003.

WERNECK, F. P. L. (Barão de Paty do Alferes). Memória sobre a Fundação e Costeio de uma fazenda na Província do Rio de Janeiro, pelo Barão do Paty do Alferes e annotada pelo Dr. Luiz Peixoto de Lacerda Werneck. Rio de Janeiro: Editores Proprietários Eduardo \& Henrique Laemmert. $3^{a}$ Edição. 1878 [on line].

ZENID G.J.;: CECCANTINI G.C.T. Identificação macroscópica de madeiras. IPT Laboratório de Madeira e Produtos Florestais. 24 p. 2007. 
ANEXO A - Exemplo Metodológico de uma Aplicação do Método AHP Proposto Por Saaty (1977) 
Extraído na integra de: SANTOS, A. R.; LOUZADA, F. L. R. O.; EUGENIO, F. C. ARCGIS 10 total : aplicações para dados espaciais. Alegre, ES : CAUFES, 2010. $184 \mathrm{p}$.

Para o mapa representar de forma mais real as condições encontradas no distrito de Aracê, vamos ponderar os dados. Com este propósito, será utilizado o método AHP proposto por Saaty (1977), através da decisão do problema em níveis hierárquicos. Esse método determina por meio da síntese dos valores dos agentes de decisão, uma medida global para cada alternativa, priorizando-as ou classificando-as ao finalizar o método (GOMES et. al., 2004).

Vamos utilizar a matriz de comparação par a par ou matriz de decisão, fazendo uso da escala fundamental de Saaty (Tabela 7.5). O método de elaboração da matriz faz uso de uma escala de comparação, em que se pode definir linearmente a hierarquia de importância entre os fatores pré-definidos (altitude, declividade, uso do solo e tipo de solo), mostrado na Tabela 7.5.

Tabela 7.5 - Escala de comparadores.

\begin{tabular}{|c|l|}
\hline VALORES & \multicolumn{1}{c|}{ IMPORTÂNCIA MÚTUA } \\
\hline $1 / 9$ & Extremamente menos importante que \\
\hline $1 / 7$ & Muito fortemente menos importante que \\
\hline $1 / 5$ & Fortemente menos importante que \\
\hline $1 / 3$ & Moderadamente menos importante que \\
\hline 1 & Igualmente importante a \\
\hline 3 & Moderadamente mais importante que \\
\hline 5 & Fortemente mais importante que \\
\hline 7 & Muito fortemente mais importante que \\
\hline 9 & Extremamente mais importante que \\
\hline
\end{tabular}

Fonte: Saaty (1977), apud Rosot (2000), adaptado.

A fase de escolha dos valores, com base na escala de comparadores, será considerada um dos momentos mais importantes de todo o processo de construção do mapa de risco de inundação, pois será neste instante, que iremos definir o grau de importância de cada fator. Dessa forma, propõe-se que sejam adotados um ou mais dos procedimentos abaixo: 
$>$ Ao comparar um impacto ambiental com o outro, o pesquisador, pode simplesmente com base em sua experiência, e em visitas de campo, definir a escala de importância.

$>\quad$ O pesquisador pode, por meio do levantamento bibliográfico, comprovar sua tese de que um impacto possui mais importância que o outro.

Uma equipe multidisciplinar, trabalhando em conjunto, com visitas de campo, debates etc. pode definir a escala que mais se aproxima da realidade.

Para o presente estudo, vamos optar por unir a ideia de que o levantamento bibliográfico, associado à observação em campo, são suficientes para um resultado satisfatório, devido principalmente ao reduzido tamanho da área delimitada para este estudo. Certamente que a união das três opções anteriores é a opção mais interessante, pois permite a interdisciplinaridade e uma melhor coerência no resultado final, visto que poderão ser apresentadas opiniões, provenientes de diversos integrantes, contribuindo para alcançar a escolha que melhor represente as ideias do grupo.

Com base nessa escala de comparação, vamos utilizar os fatores de maior importância, chegando ao resultado que pode ser observado na Tabela 7.6. Observando-a, percebe-se de que forma ela foi elaborada, pois cada elemento da matriz indica quanto o fator da coluna da esquerda é mais importante em relação a cada fator correspondente na linha superior. Logo, quando um fator é confrontado com ele mesmo, o único resultado possível é 1, pois possui igual importância. Esse limite é importante para a pesquisa, pois a partir do momento em que todos os fatores se entrecruzam uma vez, a matriz passa a ser apenas um espelho, ou inverso do procedimento inicial, restando assim o seguinte resultado de relevância para a pesquisa (Tabela 7.7 ):

Tabela 7.6 - Matriz de comparação pareada.

\begin{tabular}{|c|c|c|c|c|}
\hline Fatores & Tipo de Solo & Uso do Solo & Altitude & Declividade \\
\hline Tipo de Solo & 1 & $1 / 3$ & $1 / 5$ & $1 / 7$ \\
\hline Uso do Solo & 3 & 1 & $1 / 3$ & $1 / 5$ \\
\hline Altitude & 5 & 3 & 1 & $1 / 3$ \\
\hline Declividade & 7 & 5 & 3 & 1 \\
\hline
\end{tabular}


Tabela 7.7 - Valores de interesse para o modelo.

\begin{tabular}{|c|c|c|c|c|}
\hline Fatores & Tipo de Solo & Uso do Solo & Altitude & Declividade \\
\hline Tipo de Solo & 1 & & & \\
\hline Uso do Solo & 3 & 1 & & \\
\hline Altitude & 5 & 3 & 1 & \\
\hline Declividade & 7 & 5 & 3 & 1 \\
\hline
\end{tabular}

Possuindo os valores de importância relativa dos fatores, é possível utilizar aplicativos computacionais específicos para determinar os pesos estatísticos para cada variável. É importante ressaltar que também é possível obter esses valores manualmente, apenas dividindo cada elemento pela somatória dos elementos da coluna a que ele pertence e fazendo-se uma média entre as colunas, determinando assim cada peso. Logo, utilizando a Tabela 7.6 como exemplo, vamos determinar os pesos estatísticos como mostrado na Tabela 7.8. Dependendo do número de casas decimais, pode ocorrer uma pequena variação em cada peso calculado.

Tabela 7.8 - Determinação dos pesos estatísticos para cada variável.

\begin{tabular}{|c|c|c|c|c|c|}
\hline Fatores & Tipo de Solo & Uso do Solo & Altitude & Declividade & Pesos \\
\hline Tipo de Solo & $1 / 16=0,0625$ & $0,33 / 9,33=0,0357$ & $0,20 / 4,53=0,0441$ & $0,14 / 1,68=0,0852$ & $\mathbf{0 , 0 5 5 3}$ \\
\hline Uso do Solo & $3 / 16=0,1875$ & $1 / 9,33=0,1075$ & $0,33 / 4,53=0,0735$ & $0,20 / 1,68=0,1193$ & $\mathbf{0 , 1 1 7 5}$ \\
\hline Altitude & $5 / 16=0.3125$ & $3 / 9,33=0,3214$ & $1 / 4,53=0,2206$ & $0,33 / 1,68=0,1988$ & $\mathbf{0 , 2 6 2 2}$ \\
\hline Declividade & $7 / 16=0.4375$ & $5 / 9,33=0,5357$ & $3 / 4,53=0,6618$ & $1 / 1,68=0,5966$ & $\mathbf{0 , 5 6 5 0}$ \\
\hline
\end{tabular}

Para avaliarmos se realmente os pesos calculados são verídicos, será necessário calcular a razão de consistências (RC), que deverá apresentar um valor menor que 0,10. O RC é calculado pela seguinte equação:

\section{$\mathrm{RC}=\mathrm{IC} / \mathrm{IR}$}

Em que,

$\mathrm{RC}=$ razão de consistência.

$\mathrm{IR}=$ índice aleatório que pode ser extraído da Tabela 7.9.

IC = índice de consistência, calculado pela seguinte equação:

$I C=\left(\lambda_{\max }-n\right) /(n-1)$

Em que,

$\mathrm{n}=$ número de variáveis testadas que corresponde ao número colunas ou de linhas; e

$\lambda_{\text {max }}=$ autovetor, calculado pela seguinte equação: 
$\lambda_{\max }=\frac{1}{n_{i=1}} \sum^{n} \frac{[A w]_{i}}{w_{i}}$

Em que,

$[A w] i=$ Matriz resultante do produto da matriz de comparação pareada (Tabela 7.6) pela matriz dos pesos calculados (Wi); e

$\mathrm{Wi}=$ pesos calculados.

Tabela 7.9. Valores de IR para matrizes quadradas de ordem $\mathrm{n}$, segundo o Laboratório Nacional de Oak Ridge, EUA.

\begin{tabular}{|c|c|c|c|c|c|c|}
\hline $\mathrm{n}$ & 2 & 3 & 4 & 5 & 6 & 7 \\
\hline $\mathrm{IR}$ & 0,0 & 0,58 & 0,90 & 1,12 & 1,24 & 1,32 \\
\hline
\end{tabular}

Logo, para determinarmos a razão de consistência (RC), siga as etapas mostradas abaixo:

1. Iremos determinar primeiramente os valores de Aw multiplicando a matriz de comparação pareada (Tabela 7.6) pela matriz dos pesos calculados (Wi):

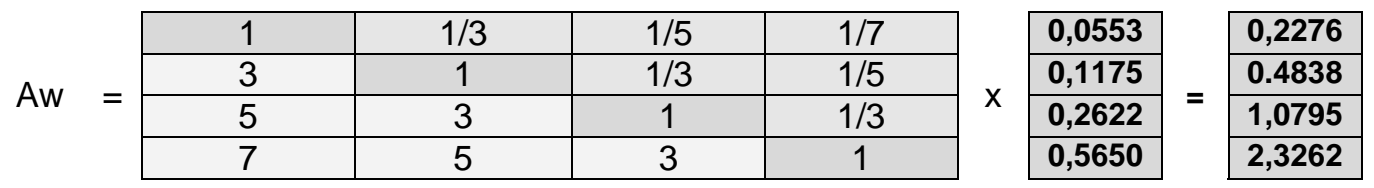

Se você não se lembra de como deve ser multiplicada uma matriz por outra, veja qual o significado do valor $\mathrm{Aw}_{1}=0,2276$ :

$$
A w_{1}=(1 \times 0,0553+1 / 3 \times 0,1175+1 / 5 \times 0,2622+1 / 7 \times 0,5650)=0,2276
$$

2. Iremos calcular o autovetor $\left(\lambda_{\max }\right)$ :

$\lambda_{\max }=\frac{1}{n} \sum_{i=1}^{n} \frac{[A w]_{i}}{w_{i}}=\frac{1}{4}\left(\frac{0,2276}{0,0553}+\frac{0,4838}{0,1175}+\frac{1,0795}{0,2622}+\frac{2,3262}{0,5650}\right)=4,1169$

3. Iremos calcular o índice de consistência (IC):

IC $=\left(\lambda_{\max }-n\right) /(n-1)=(4,1169-4) /(4-1)=0,039$

4. Finalmente, iremos calcular a razão de consist6encia (RC):

OBS: Na Tabela 7.9 o valor de IR é de 0,90, logo:

$\mathrm{RC}=\mathrm{IC} / \mathrm{IR}=0,039 / 0,90=0,0433<0,10$

Pelo fato do valor da razão de consistência ser menor que 0,10 , os pesos calculados para nosso modelo são aceitáveis. 